\title{
MASTR
}

\section{Preliminary Analysis of Alternative Fuel Cycles for Proliferation Evaluation}

\section{OAK RIDGE NATIONAL LABORATORY}




\section{DISCLAIMER}

Portions of this document may be illegible in electronic image products. Images are produced from the best available original document. 


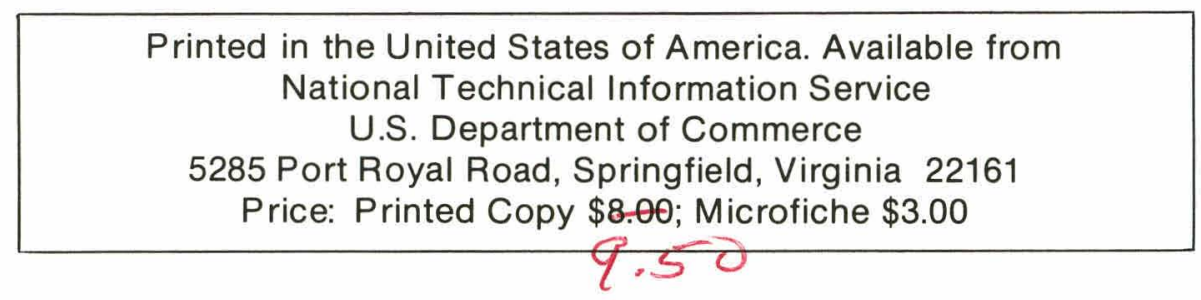

This report was prepared as an account of work sponsored by the United States Government. Neither the United States nor the Energy Research and Development Administration/United States Nuclear Regulatory Commission, nor any of their employees, nor any of their contractors, subcontractors, or their employees, makes any warranty, express or implied, or assumes any legal liability or responsibility for the accuracy, completeness or usefulness of any information, apparatus, product or process disclosed, or represents that its use would not infringe privately owned rights. 


\section{DISCLAIMER}

This report was prepared as an account of work sponsored by an agency of the United States Government. Neither the United States Government nor any agency Thereof, nor any of their employees, makes any warranty, express or implied, or assumes any legal liability or responsibility for the accuracy, completeness, or usefulness of any information, apparatus, product, or process disclosed, or represents that its use would not infringe privately owned rights. Reference herein to any specific commercial product, process, or service by trade name, trademark, manufacturer, or otherwise does not necessarily constitute or imply its endorsement, recommendation, or favoring by the United States Government or any agency thereof. The views and opinions of authors expressed herein do not necessarily state or reflect those of the United States Government or any agency thereof. 
Contract No. W-7405-eng-26

PRELIMINARY ANALYSIS OF ALTERNATIVE FUEL CYCLES FOR PROLIFERATION EVALUATION

\author{
$\checkmark$ \\ M. J. Steindler and D. S. Webster \\ ARGONNE NATIONAL LABORATORY \\ $\checkmark$ \\ H.C.F. Ripfel, M. J. Barr, S. R. Fields, E. M. Greene \\ R. L. Plum, and D. D. Scott \\ HANFORD ENGINEERING DEVELOPMENT LABORATORY \\ R. H. Rainey, W. L. Carter, D. R. Johnson, and J. A. Horak \\ OAK RIDGE NATIONAL LABORATORY
}

F. R. Field and F. E. Driggers SAVANNAH RIVER LABORATORY

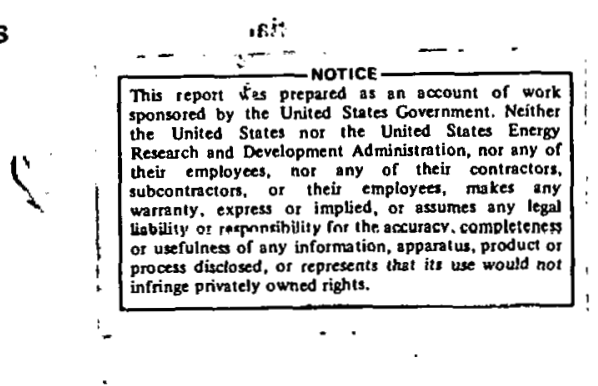

NOTICE This document contains iriformation of a preliminary nature.

It is subject to revision or correction and therefore does not represent a

final report.

OAK RIDGE NATIONAL LABORATORY

Oak Ridge, Tennessee 37830

operated by

UNION CARBIDE CORPORATION

for the

ENERGY RESEARCH AND DEVELOPMENT ADMINISTRATION 
THIS PAGE

WAS INTENTIONALLY

LEFT BLANK 


\section{Foreword}

On April 7, 1977, President Carter made the following nuclear power policy statements:

"The benefits of nuclear power are thus very real and practical. But a serious risk accompanies world-wide use of nuclear power--the risk that components of the nuclear power process will be turned to providing atomic weapons."

"The U.S. is deeply concerned about the consequences for all nations of a further spread of nuclear weapons or explosive capabilities. We believe that these risks would be vastly increased by the further spread of sensitive technologies which entail direct access to plutonium, highly enriched uranium or other weapons useable material."

"We will redirect funding of U.S. nuclear research and development programs to accelerate our research into alternative nuclear fuel cycles which do not involve direct access to materials useable in nuclear weapons."

As a result of this policy statement, ERDA embarked on a vigorous effort aimed at evaluating various alternative fuel cycle systems having possible non-proliferation advantages. Over 60 possible candidates were identified for preliminary evaluation. Contractors for the Division of Waste Management, Production and Reprocessing, ERDA, proceeded to characterize and define the candidate alternatives from a fuel cycle processes and operations standpoint. This document contains these preliminary definitions in the format of functional flow diagrams and tabulated evaluations of the operations shown in these diagrams. In addition to the definitions presented herein, process streams containing fissionable material were identified; and the state-of-the-art for each process function has been included.

WPR is continuing to assess these nuclear fuel cycle alternatives from the viewpoint of costs, materlals flows and inventories, and proliferation potential. A follow-on document will be issued when the work is completed.

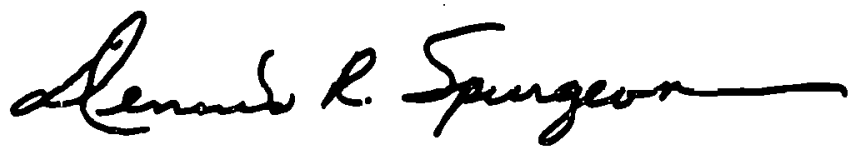

Dennis R. Spurgeon, Assistant Director for Fuel Cycle

Division of Waste Management, Production and Reprocessing 
THIS PAGE

\section{WAS INTENTIONALLY \\ LEFT BLANK}


CONTENTS

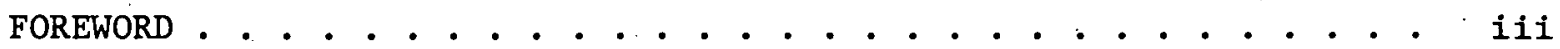

1. INTRODUCTTON . . . . . . . . . . . . ........ 1

2. FUEL CYCLE EVALUATIONS FOR URANIUM-PLUTONIUM FUELS IN THE LMFBR AND THE GCFR (Argonne National Laboratory) . . . . . . . . 11

3. FUEL CYCLE EVALUATIONS FOR URANIUM-PLUTONIUM FUELS IN THE LMFBR AND LMFBR/LWR (Hanford Engineering Development

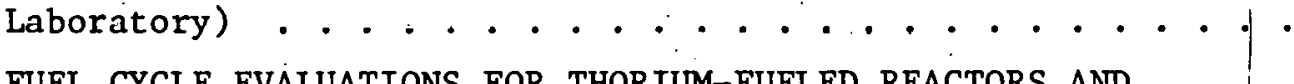

4. FUEL CYCLE EVALUATIONS FOR THORIUM-FUELED REACTORS AND

5. FUEL CYCLE EVALUATIONS FOR URANIUM-PLUTONIUM FUELS IN LWRs (Savannah River Laboratory) . . . . . . . . . . . . 


\section{INTRODUCTION}

The Unfted States Energy Research and Development Administration Division of Nuclear Research and Applications (ERDA-NRA) proposed 67 nuclear fuel cycles ${ }^{1}$ for assessment as to their nonproliferation potential. Although the candidate alternative systems present distinct cases with respect to reactor (or combinations of reactors) operations, certain reprocessing and refabrication operations are common to several cases, making it expedient to treat the cases generically rather than individually. The object of the assessment is to determine which fuel cycles pose inherently low risk for nuclear weapon proliferation while retalning the major benefits of nuclear energy. Economics, resource use, and timeliness are also factors in the evaluation. Argonne Nationa1 Laboratory (ANL), Hanford Engineering Dvelopment Laboratory (HEDL), Oak Ridge National Laboratory (ORNL), and Savannah River Laboratory (SRL) participated in studying the back cycles of the candidate systems. This is a preliminary analysis of these fuel cycles to develop the fuel recycle data that will complement reactor data, environmental data, and polftical considerations, which must be included in the overall evaluation. Back cycle evaluations per se are inadequate for eliminating certain fuel cycles from further consideration. This report presents the preliminary evaluations from the four Laboratories and is the basis for a continuing in-depth study.

The proposed fuel cycles are identified in Table 1.1 and correlated with the responsible Laboratory and the location in this report where the evaluation can be found. Case assignments among the several participants were such that presentation of results on a case-by-case basis was impractical. Hence the evaluations are presented in alphabetical order by participating institution. ORNL assumed the responsibility for all thorium cycles plus high-temperature gas-cooled reactor (HTGR) cycles; SRL for uranium-plutonium fuels in light-water reactor (LWR), heavy-water reactor (HWR), and spectral shift systems; ANL/HEDL for uranium-plutonium fuels in the liquid-metal fast breeder reactor (LMFBR) and the gas-cooled fast breeder reactor (GCFR). Advanced concepts (Group 6) and certain 
Table 1.1." Index for Correlating ERDA-HRA Identification of Fuel Cycles with

Participants in Study and Reprccessing and Refabrication Evaluations

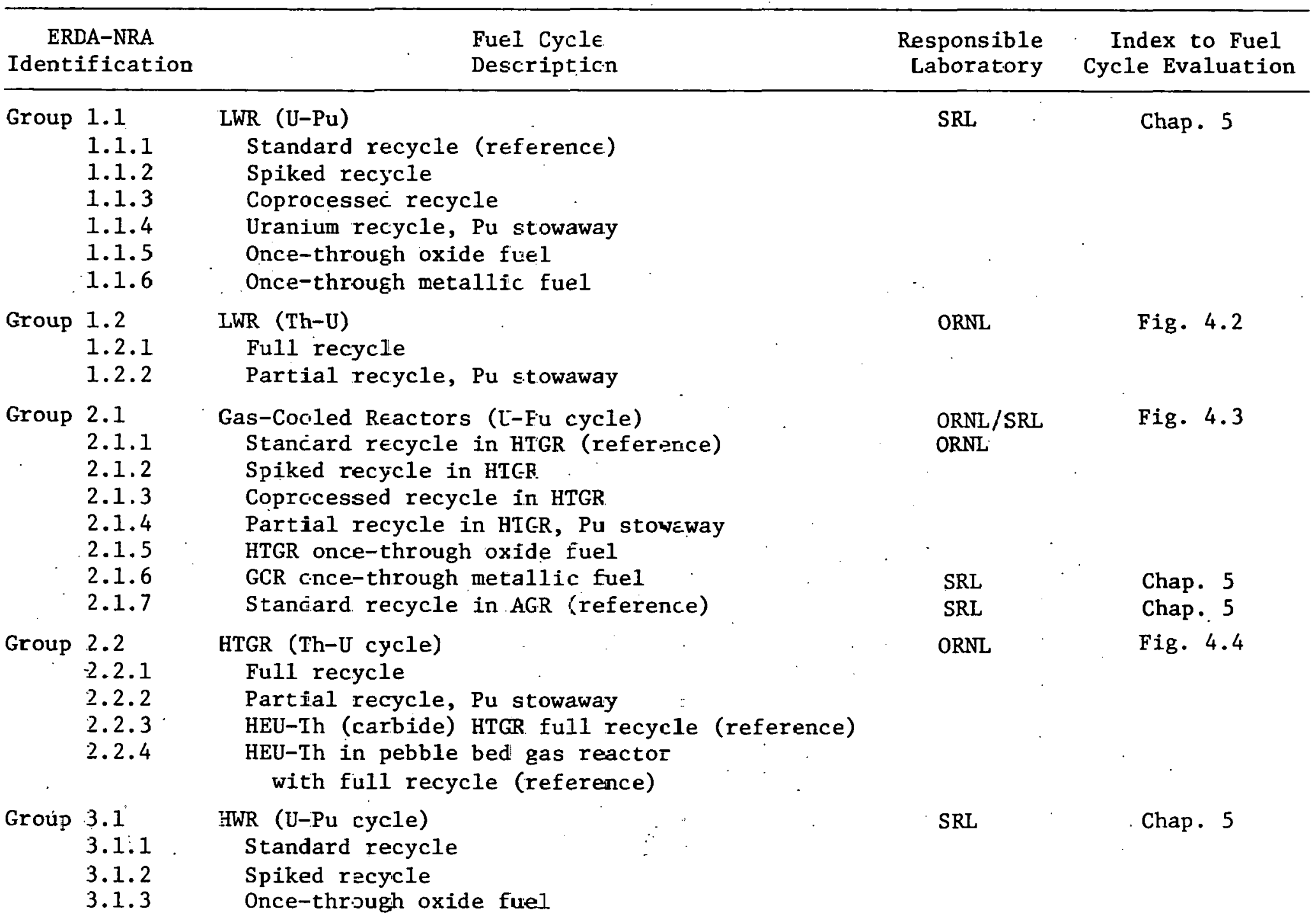


Táble 1.1. (Continued)

\begin{tabular}{|c|c|c|c|c|}
\hline Ident & $\begin{array}{l}D A-N R A \\
\text { ification. }\end{array}$ & $\begin{array}{l}\text { Fue1 Cycle } \\
\text { Description }\end{array}$ & $\begin{array}{r}\text { Responsible } \\
\text { Laboratory }\end{array}$ & $\begin{array}{l}\text { Index to Fuel } \\
\text { Cycle Evaluation }\end{array}$ \\
\hline Group & $\begin{array}{l}3.2 \\
3.2 .1 \\
3.2 .2\end{array}$ & $\begin{array}{l}\text { HWR (Th-U cycle) } \\
\text { Full recycle } \\
\text { Partial recycle, Pu stowaway }\end{array}$ & ORNL & Fig. 4.2 \\
\hline Group & $\begin{array}{l}3.3 \\
3.3 .1 \\
3.3 .2\end{array}$ & $\begin{array}{l}\text { LWR/HWR tandem cycle } \\
\text { Tandem cycle with reconstituted fuel } \\
\text { Tandem cycle without reconstituted fuel }\end{array}$ & SRL & Chap. 5 \\
\hline Group & $\begin{array}{l}3.4 \\
3.4 .1 \\
3.4 .2\end{array}$ & $\begin{array}{l}\text { Spectral shift reactors } \\
\text { Once-through uranium cycle } \\
\text { Th-U full recycle }\end{array}$ & $\begin{array}{l}\text { SRL / ORNL } \\
\text { SRL } \\
\text { ORNL }\end{array}$ & $\begin{array}{l}\text { Chap. } 5 \\
\text { Fig. } 4.2\end{array}$ \\
\hline Group & $\begin{array}{l}4.1 \\
4.1 .1 \\
4.1 .2 \\
4.1 .3\end{array}$ & $\begin{array}{l}\text { LMFBR (U-Pu cycle) } \\
\text { LMFBR/LWR standard recycle (reference) } \\
\text { LMFBR/LWR coprocessed recycle oxide fuel } \\
\text { LMFBR/LWR coprocessed recycle carbide fuel }\end{array}$ & ANL / HEDL & Chap. 2,3 \\
\hline Group & $\begin{array}{l}4.2 \\
4.2 .1 \\
4.2 .2 \\
4.2 .3\end{array}$ & $\begin{array}{l}\text { LMFBR (Th-U cycle) } \\
\text { U-Pu-Th full recycle LMFBR/LWR } \\
{ }^{23}{ }^{3} \mathrm{U} /{ }^{238} \mathrm{U} / \mathrm{Th} \text { LMFBR/LWR, } \\
\mathrm{U} \mathrm{recycle} \text {, Pu stowaway } \\
2{ }^{3} \mathrm{U} / \mathrm{Th} \mathrm{LMFBR} / \mathrm{LWR} \text { full recycle }\end{array}$ & ORNL & Fig. 4.5 \\
\hline Group & $\begin{array}{l}5.1 \\
5.1 .1 \\
5.1 .2 \\
5.1 .3\end{array}$ & $\begin{array}{l}\text { GCFR (U-Pu cycle) } \\
\text { GCFR/LWR standard recycle (reference) } \\
\text { GCFR/LWR coprocessed recycle oxide fuel } \\
\text { GCFR/LWR coprocessed recycle carbide fuel }\end{array}$ & ANL/HEDL & Chap. 2 \\
\hline Group & $\begin{array}{l}5.2 \\
5.2 .1 \\
5.2 .2 \\
5.2 .3\end{array}$ & 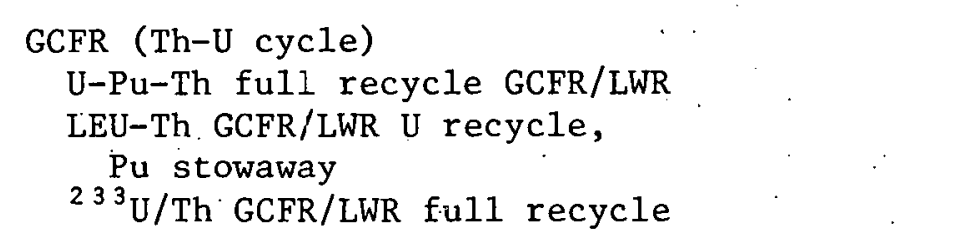 & ORNL & Fig. 4.6 \\
\hline
\end{tabular}


Table 1.1. (Continued)

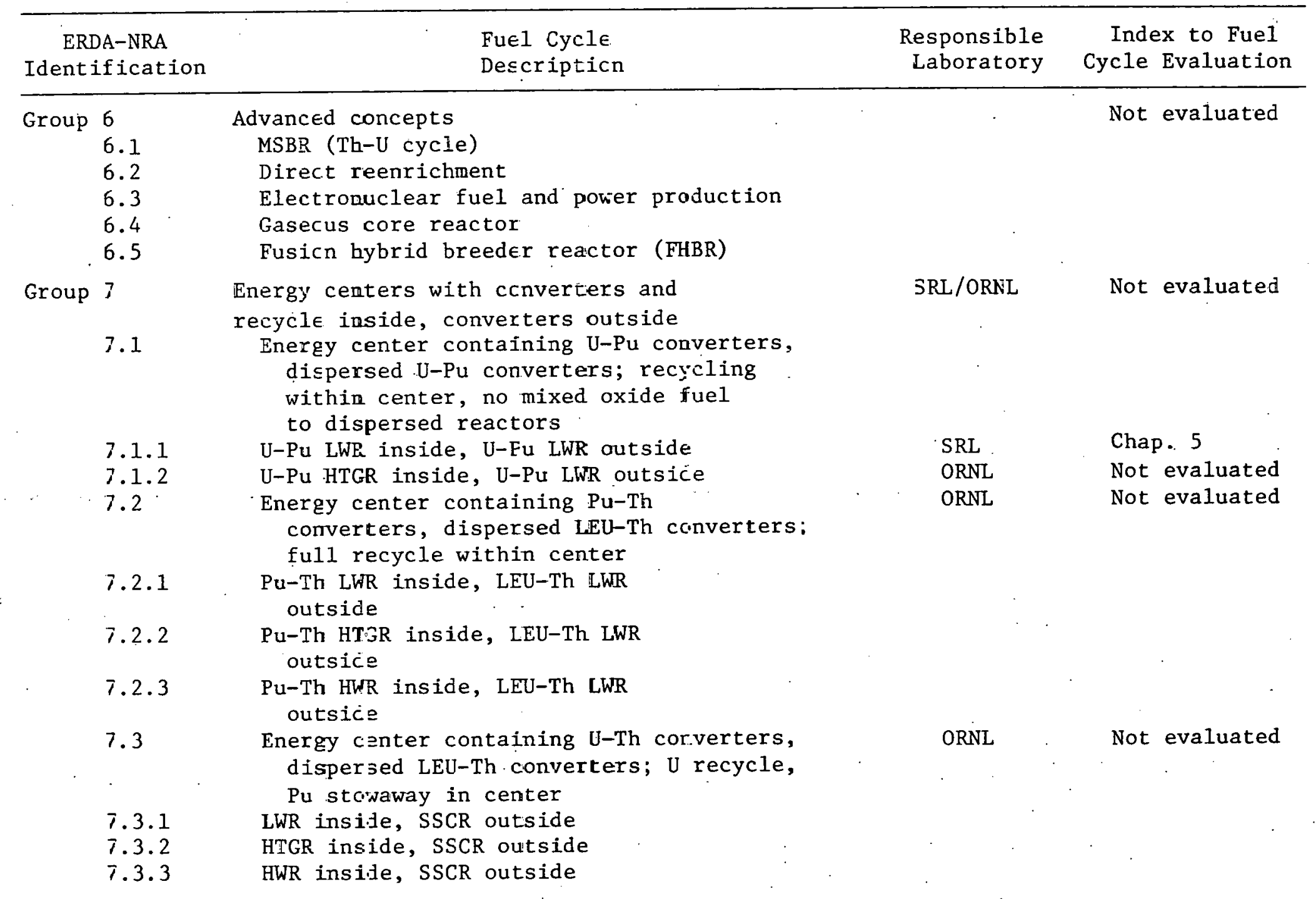


Table 1.1. (Continued)

\begin{tabular}{|c|c|c|c|c|}
\hline $\begin{array}{r}\text { ERD } \\
\text { Identi }\end{array}$ & $\begin{array}{l}\text { DA-NRA } \\
\text { ification }\end{array}$ & $\begin{array}{l}\text { Fuel Cycle } \\
\text { Description }\end{array}$ & $\begin{array}{r}\text { Responsible } \\
\text { Laboratory }\end{array}$ & $\begin{array}{l}\text { Index to Fuel } \\
\text { Cycle Evaluation }\end{array}$ \\
\hline Group & $\begin{array}{l}8 \\
8.1 \\
8.1 .1 \\
8.1 .2 \\
8.1 .3 \\
8.2 \\
8.2 .1 \\
8.2 .2 \\
8.2 .3\end{array}$ & $\begin{array}{l}\text { Energy centers containing U-Pu breeders } \\
\text { and U-Pu-FP fuel sent to dispersed converters } \\
\text { LMFBR inside } \\
\text { LWR outside } \\
\text { HTGR outside } \\
\text { HWR outside } \\
\text { GCFR inside } \\
\text { LWR outside } \\
\text { HTGR outside } \\
\text { HWR outside }\end{array}$ & $\begin{array}{l}\text { ANL } \\
\text { SRL } \\
\text { ORNL } \\
\text { SRL } \\
\text { ANL } \\
\text { SRL } \\
\text { ORNL } \\
\text { SRL }\end{array}$ & $\begin{array}{l}\text { Chap. } 2 \\
\text { Not evaluated } \\
\text { Not evaluated } \\
\text { Not evaluated } \\
\text { Chap. } 2 \\
\text { Not evaluated } \\
\text { Not evaluated } \\
\text { Not evaluated }\end{array}$ \\
\hline Group & $\begin{array}{l}9.1 \\
9.1 .2 \\
9.1 .3 \\
9.2 \\
9.2 .1 \\
9.2 .2 \\
9.2 .3\end{array}$ & $\begin{array}{l}\text { Energy center with breeders with U-Pu } \\
\text { core, Th blanket inside; LEU-Th fuel } \\
\text { sent to dispersed converters } \\
\text { LMFBR inside } \\
\text { LWR outside } \\
\text { HTGR outside } \\
\text { HWR outside } \\
\text { GCFR inside } \\
\text { LWR outside } \\
\text { HTGR outside } \\
\text { HWR outside }\end{array}$ & ORNL & $\begin{array}{l}\text { Not evaliated } \\
\text { : }\end{array}$ \\
\hline Group & $\begin{array}{l}10.1 \\
10.2\end{array}$ & $\begin{array}{l}\text { Energy center containing breeders with } \\
\text { U-Pu core, Th blanket inside; LEU-Th } \\
\text { breeder (LMFBR) outside } \\
\text { LMFBR inside } \\
\text { GCFR inside }\end{array}$ & $\begin{array}{l}\text { ORNL/HEDL } \\
\text { HEDL }\end{array}$ & Not evaluated \\
\hline
\end{tabular}


combinations of cycles involving energy centers were not evaluated in this preliminary study. This study might not include all interesting cases, and other fuel cycles may be added for future study.

The relationship of the back cycle to the overall fuel cycle is shown in Fig. 1.1 .

\subsection{ELEMENTS OF THE EVALUATION}

Level 0 and Level $I$ functional flow diagrams were prepared to define principal operations of reprocessing and refahrication. Each operation was characterized by five elements, which were chosen to provide a cursory technical assessment of the required fuel cycle and relate the nuclear material in process to its attractiveness for diversion. These elements are needed development, material location, material description, convertibility, and radiation hazard. The ratings assigned to these elements allow comparison among fuel cycles and broadly characterize process streams containing fissionable material but are insufficiently detailed to permit exclusion of certain fuel cycles; however, this method of rating does bring out advantages of some cycles over others.

Needed development relates to the state of the art of the eovcral operations on the functional flow diagram to provide an appraisal of these operations with respect to the particular fuel cycle. The rating defines the research phase to which development of the process step has progressed in the sequence: cold laboratory, hot laboratory, cold engineering, hot engineering, prototype, demonstration facility (hot pilot plant or small commercial facility), and developed. For example, hot engineering would indicate that development has progressed through cold laboratory, hot laboratory, and cold engineering stages but needs hot engineering and all stages beyond.

Maturlal location identifies the factiley that is needed to house the process step, such as hot cell, glove box, shielded alpha facility, or hands-on facility. Material location is probably not a serious deterrent to proliferation but could impede diversion from safeguards considerations. The importance of material location to proliferation can be significantly influenced by equipment design, operating procedures, and administrative controls. 
ORML DWO 77-1A15

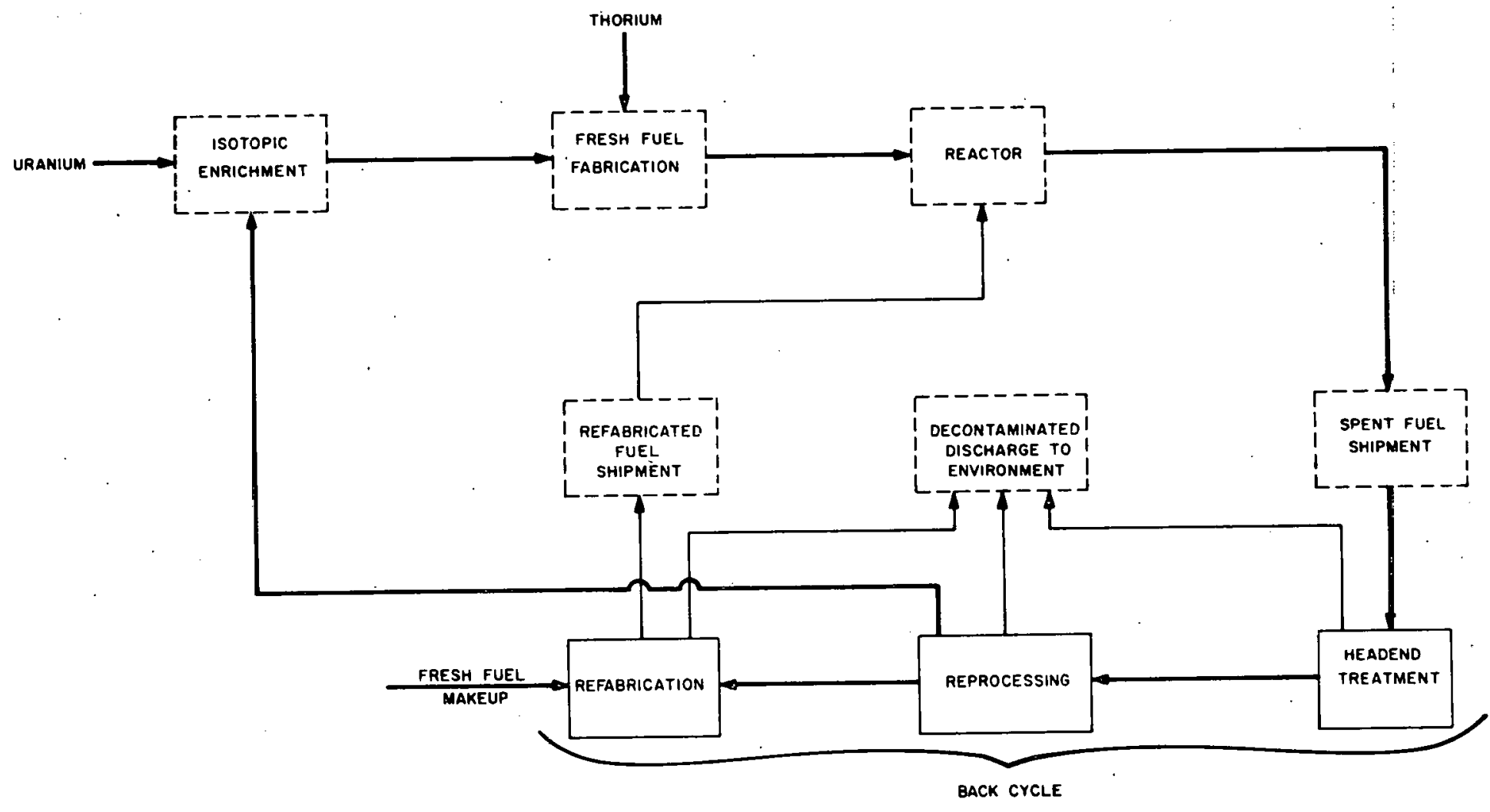

Fig. 1.1. Level 0 Functional Flow Diagram for Recycle of Fission Reactor Fuel. 
Material description Identifies the material and/or stream in the process operation. Chemical and 1sotopic concentrations were not considered in this preliminary evaluation. However, these quantities need to be assessed in an in-depth study.

Convertibility refers to the usefulness of diverted material for making a weapon. An arbitrary scale, using nonfissionable, $a, b, c$, and $d$, is used to give a qualitative rating to diverted material where

- nonfissionable identifies material that cannot be used for a weapon;

- a identifies radioactive fissionable material that requires a shielded isotope separation facility for upgrading to weapon quality (e:g., ${ }^{233} \mathrm{U}$ denatured with ${ }^{238} \mathrm{U}$ ). This material may be less attractive as a starting point for fabricating a weapon than natural uranium;

- $b$ identifies material that requires an isotope separation facility such as $<20 \% 335_{\mathrm{U}}$ in $238 \mathrm{U}$. A country with such separation equilpment could make a weapon without diverting reactor fuel;

- c refers to highly radioactive material requiring remotely operated engineering equipment for chemically separating weapon material frum impurities;

- $d$ identifies weapon material that can be separated from impurities through hands-on operations, or material that is in a form suitable for a weapon without additional treatment. Radiation hazard of a process step is a measure of the danger in handling the fissile material if it were removed from its containment for conversion to a weapon. Also, it can be considered as a measure of the danger associated with the alteration of a process step (piping changes, installation of new equipment, modification of existing equipment, etc. In a confinement area) for diversion of nuclear material. Only a rudimental rating is given in this study since computed data for the candidate fuel cycles has not been completed. The ratings used in this study are necessarily broad in context and are defined as follows:

- high identifies a radiation level equivalent to $L D_{50}$ at $30 \mathrm{~cm}$ in a few minutes, nomina1ly $>10^{4} \mathrm{R} / \mathrm{hr}$; 
- medium identifies a radiation level capable of producing harmful physlological effects in one day (10 to $10^{4} \mathrm{R} / \mathrm{hr}$ );

- Low identifles a radiation level resulting in severe exposure in several days but insufficient to prevent fabrication of a weapon ( $<10 \mathrm{R} / \mathrm{hr}$ ); such exposure could lead eventually to death;

- negligible identifies no harmful radiation effects from the material being handled.

In each definition it is tacitly assumed that the radiation level is that associated with the quantity of material required for a weapon or, for in-cell alterations, the total amount of material in the cell. The presence of a highly radioactive isotope of the fissile material, such as ${ }^{232} \mathrm{U}$ in ${ }^{233} \mathrm{U}$, was assumed to make the fissile material less attractive than fissile material containing radioactive nuclides that can be chemically removed.

\subsection{EVALUATION FORMAT}

The evaluations of the nuclear fuel cycles named in Table 1.1 are tabulated in the following sections accompanied by the appropriate functional flow diagrams. Separate tables and diagrams are provided for reprocessing and refabrication operations. Items in the tables are keyed to operations shown on the diagrams and are assessed according to the elements discussed in Sect. 1.1. The appraisals of the operations are preliminary diagnoses of factors to be considered in evaluating the relative attractiveness for weapon production of nuclear materiai diverted from the process step. This study does not rate relative attractiveness since it is premature to do so without also considering the portions of the nuclear fuel cycle that are outside reprocessing and refabrication.

\subsection{FUTURE STUDIES}

This study has identified a need to develop additional information on the back cycles of the candidate systems to facilitate the choice of the system that has the least proliferation risk. The initial list ${ }^{1}$ of fuel cycles did not include fast breeder systems that operate with a thorium-plutonium core and a thorium blanket. Such systems have high 
breeding gain, good material performance, possible application in energy centers, and produce ${ }^{233} \mathrm{U}$ fuel. These systems are to be included in the next phase of this study.

The attractiveness of diverted fissile material cannot be fully appreciated without an assessment of the technology and resources needed to produce a weapon. Cost, manpower, time, and technical sophistication are factors to be evaluated, Including "quick and dirty" routes from the point of diversion to the ultimate goal. Each functional flow diagram needs to be analyzed (perhaps at Level 2 detail) to identify diversion sidestreams and their required additional treatment.

The analysis should also include an appraisal of the difficulty, cost, manpower, and time to modify existing back cycle facilities to obtain access to fissile material.

Mass flow data, including isotopic compositions, will be developed to give a relationship between spent reactor fuel and weapon capability. In-depth analyses of the back cycles will complement companion studies on reactor performance and resource requirements in order to identify the fuel cycle (or cycles) that offer the greatest proliferation resistance.

\subsection{REFERENCES}

1. United States Energy Research and Development Administration, Nonproliferation Alternative Systems Assessment Program - Preliminary Progrom Plan, (May 1977). 
2. FUEL . CYCLE EVALUATIONS FOR URANIUM-PLUTONIUM FUELS IN THE LMFBR AND THE GCFR (Argonne National Laboratory)

M. J. Steindler/D. S. Webster

CORE AND AXIAL BLANKET OF U/PU FAST BREEDERS

\author{
Group 4.1 LMFBR U-Pu Cycle \\ 4.1.1 LMFBR/LWR standard recycle (Reference) \\ 4.1.2 LMFBR/LWR coprocessed, contaminated, recycled oxide fuel \\ 4.1.3 LMFBR/LWR coprocessed, contaminated, recycled carbide fuel \\ Reprocessing and refabrication of cores and axial blankets \\ for the above options are treated in this section.
}

Group $5.1 \quad$ GCFR U-Pu Cycle

5.1.1 GCFR/LWR standard recycle (Reference)

Not treated separately, since the system is essentially

identical to option 4.1 .1 with regard to both chemistry

and proliferation susceptibility. (Since there is no

sodium present, step 3.3 in reprocessing is eliminated.)

5.1.2 GCFR/LWR coprocessed, contaminated, recycled oxide fuel

Not treated separately, since it is the same as option 4.1 .2

5.1.3 GCFR/LWR coprocessed, contaminated, recycled carbide fuel

Not treated separately - same as option 4.1 .3

8.1 Energy center containing a U/Pu LMFBR

A reactor within an energy center is postulated to be free

of proliferation possibilities by means of institutional

arrangements for the center. Consequently, the LMFBR system is that of option 4.1 .1 .

8.2 Energy center containing a U/Pu GCFR

This option includes the GCFR of option 5.1.1 
Option 4.1.1 LMFBR/LWR Full U/Pu Recycle, Oxide Fuel

(Reference Case)

Option 4.1.1 is shown in the attached Figure B-11 taken from the draft "Preliminary PIan for Nonproliferation Alternatives Assessment Program." The figure represents two different periods of time. During the first period LWR's are operated with low-enriched uranium fuel (LEU) which is reprocessed to provide both plutonium for fabricating LMFBR cores (and some LWR fuel), and uranium that goes back to the isotope enrichment plant. As construction of LMFBR's progresses, a situation is eventually reached in which no additional $\mathrm{LMFB} \bar{R}^{\prime}$ s are required; during this second period the plutonfum bred in excess of that needed to fuel the existing LMFBR's is recycled to LWR's. This fission-power sequence is that envisioned for fast breeders before the recent reconsideration of alternatives, and is consequently a reference case.

The functional flow diagrams (FFD) and process rating tables that follow Figure B-11 deal only with the LMFBR core and axial blanket; the first set of FFD's and tables apply to reprocessing, the second set to refabrication.

Tho analyoic of LWR Fusl reproooesing and rofabrioation io tho oame as for option 1.1.1, so will not be repeated here. Reprocessing of the radial blanket is the same as for LWK fuel, but with inclusion of the sodium removal stcp, opcration 3.3 of the attached eore assessment. 


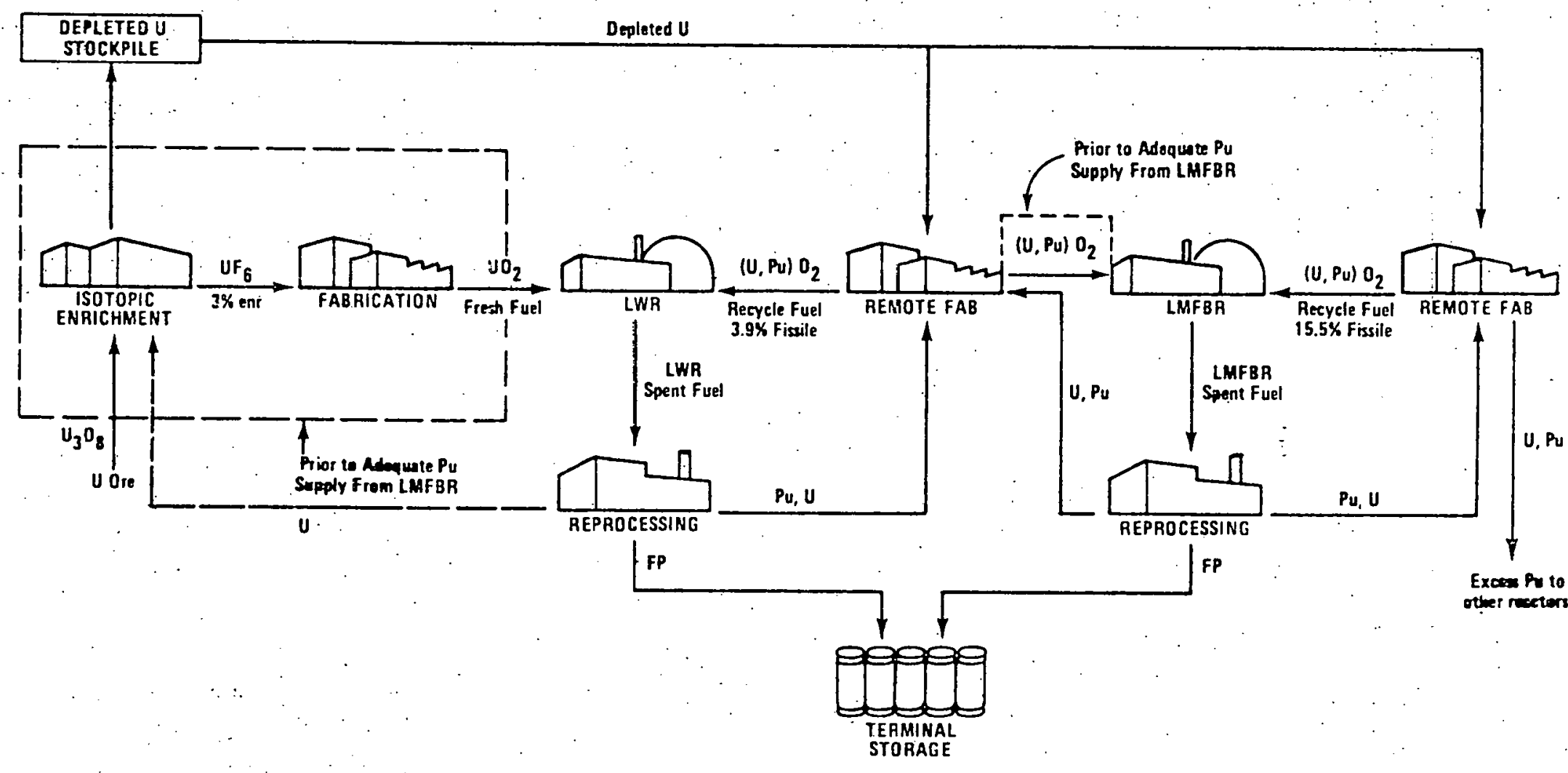

\section{LMFBR/LWR FULL U-PU RECYCLE}

[This Diagram Applies to Option 4.1.1]

Figure B-11 
Option 4.1.1

LMFER/LWR, U-Pu Recycle--oxtce Fuel

(Reference Case)

Level 0

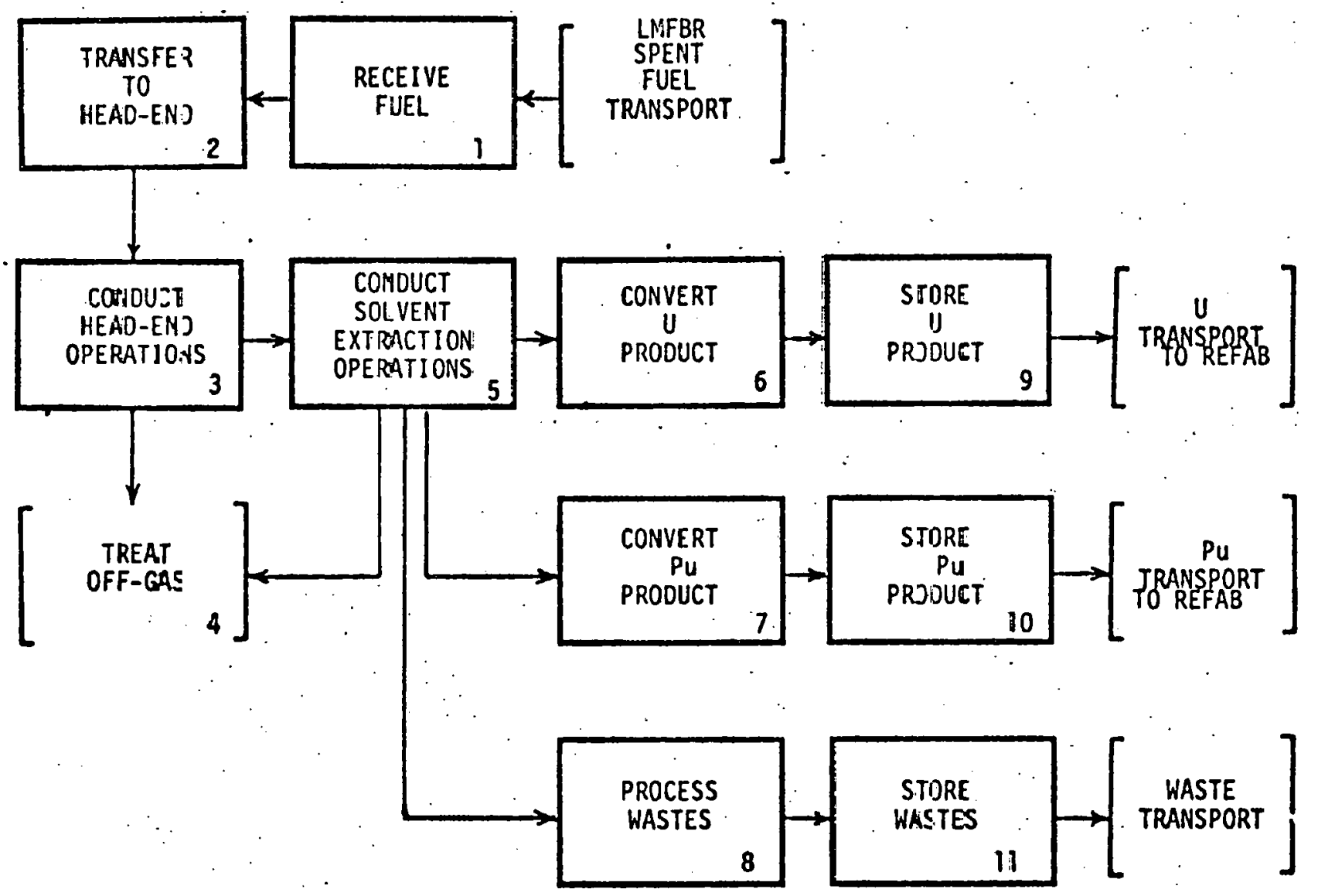


Uption 4.1.1

LMFBR/LWR; U-Pu Recycle--Oxide Fuel

(Reference Case) .

Level 1
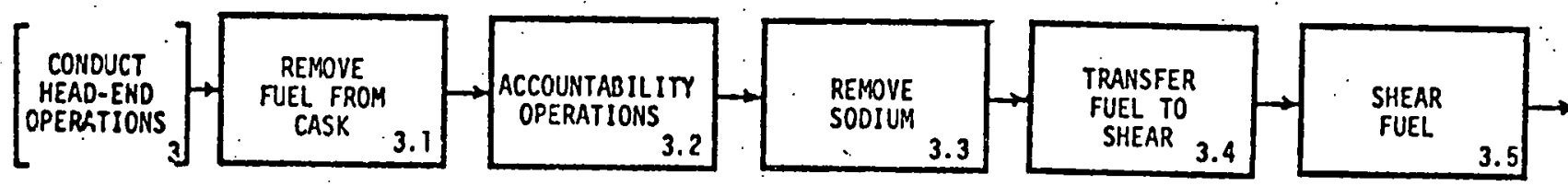

TRANSFER TO

VOLOXIOIZER

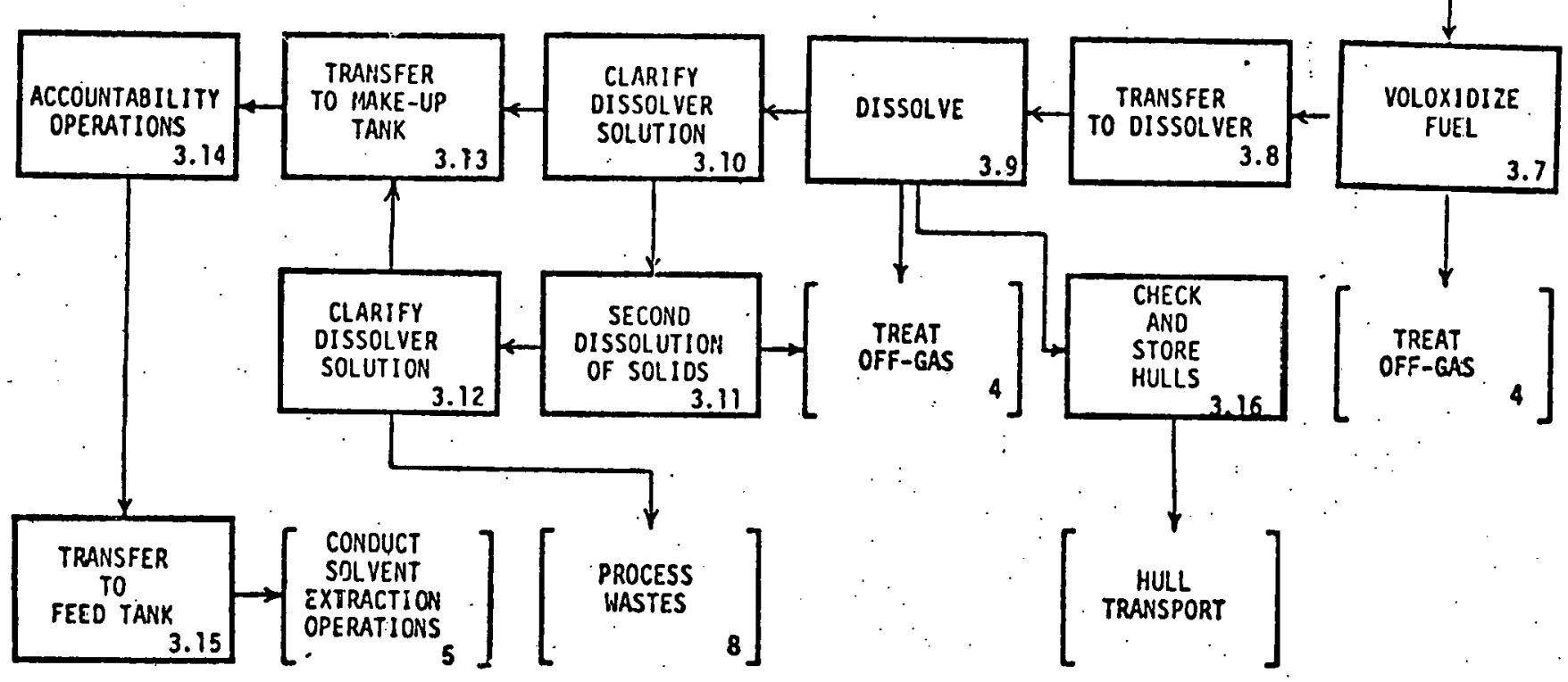


Option: 4.1.1

LMFBR;LiNR, U-Pu REcycle--0xide Fuel

(Referer:ce Case)

Level 1

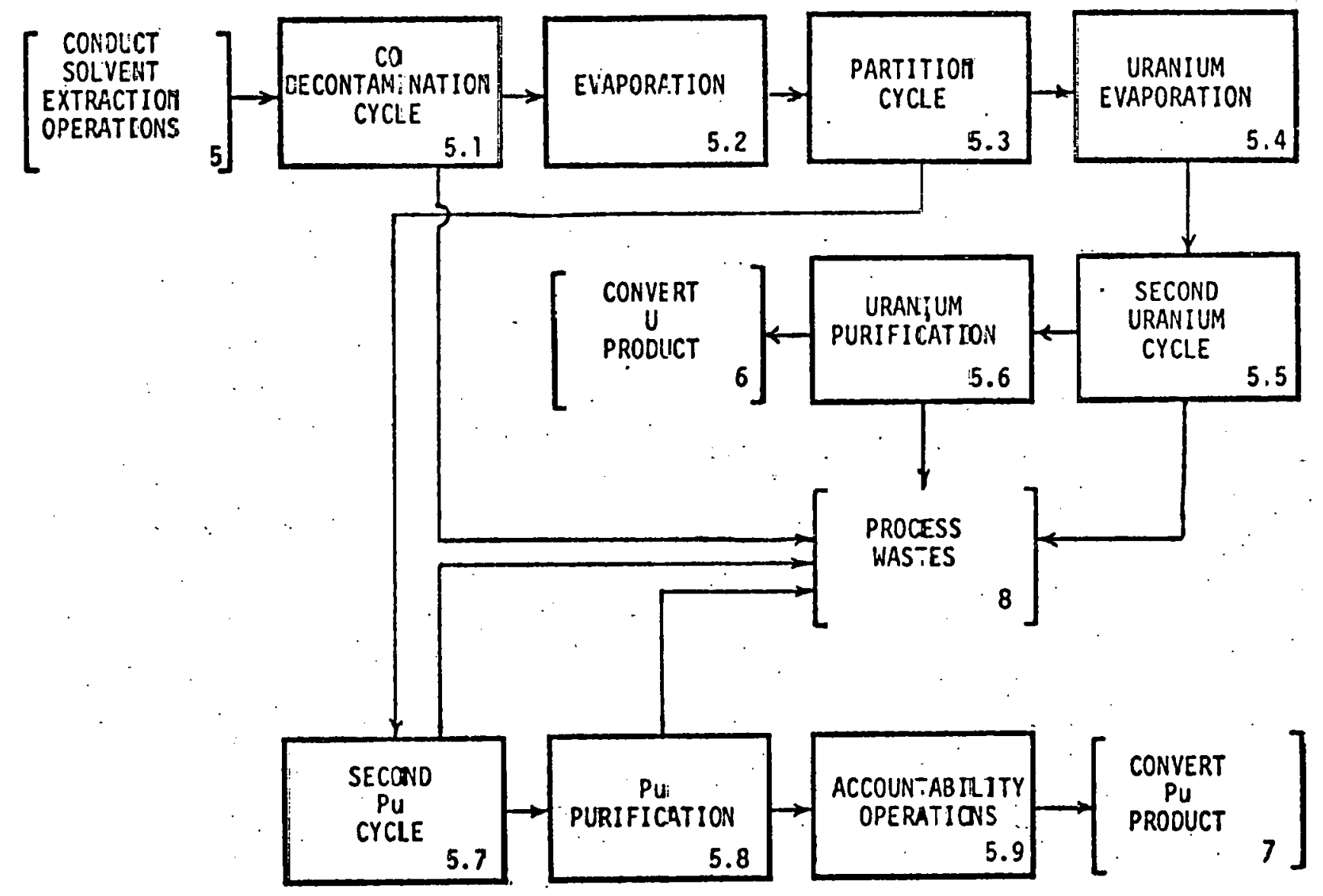


Option 4.1.1

LMFBR/LWR, U-Pu Recycle--oxide Fuel

(Reference Case)

Level 1

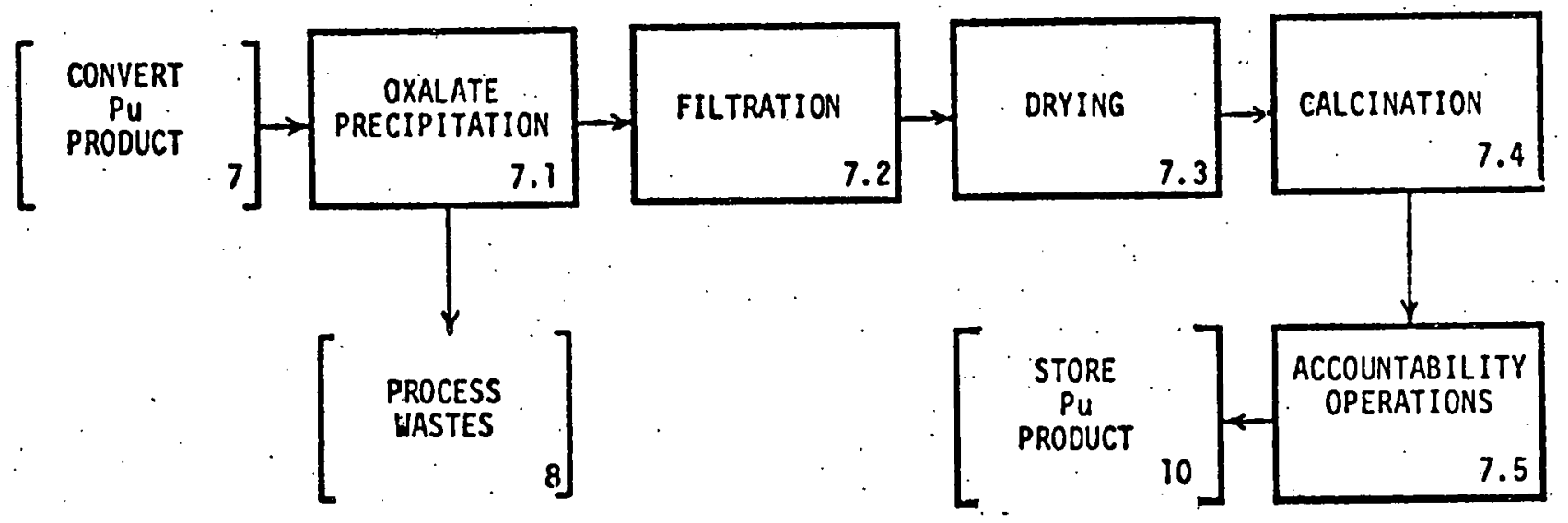


Option 4.1.1 HFBR/LWR U-Pu Recycle, Oxide Fuel (Refereice)

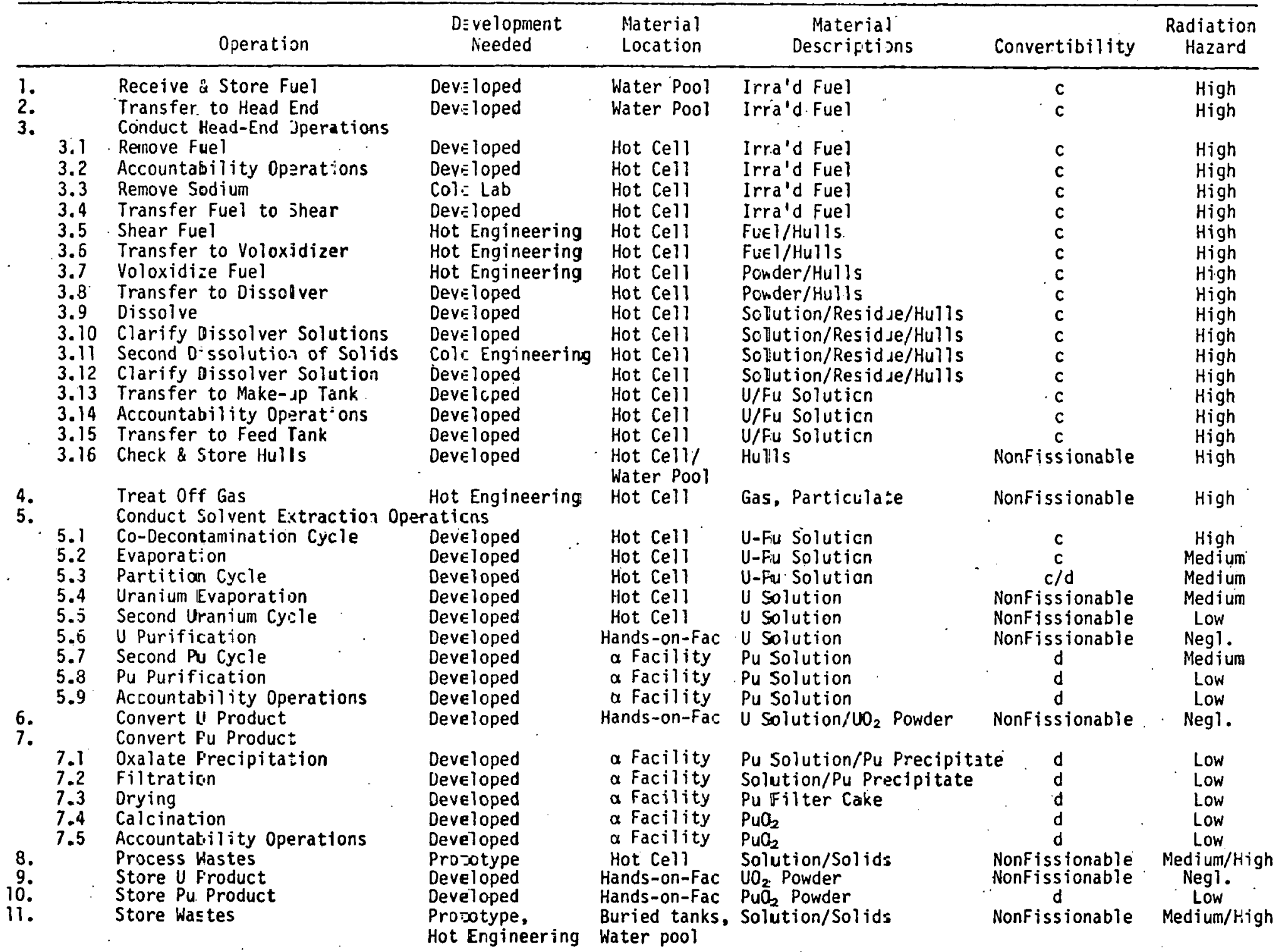


Option 4.1.2. LMFBR/LWR, U/Pu Coprocessed, contaminated, Recycled oxide Fuel

This option is similar to option 4.1 .1 except that plutonium is always in the presence of uranium and enough fission products to make diversion difficult.

The following functional flow diagrams and process rating tables deal only with the LMFBR core and axial blanket: the first set of FFD's and tables apply to reprocessing, the second set to refabrication.

The assessment of LWR fuel reprocessing and refabrication is the same as for option 1.1.3, so will not be repeated here. 
Option $4 . \dot{-} .2$

LMFBR/LHR, U-PU Coprosessed, Contaminated, and Recycled--0xide Fuel

Level 0

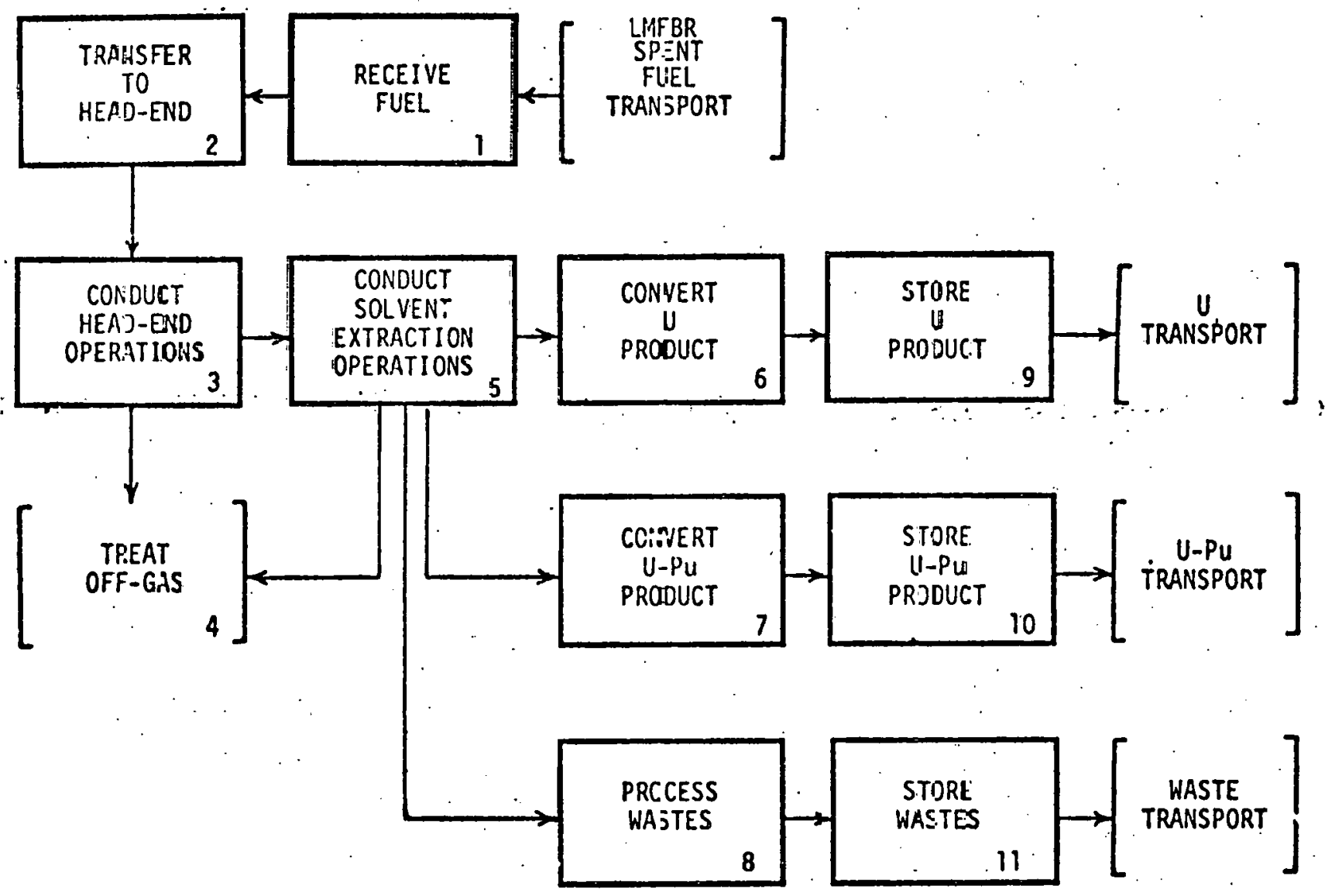


Option 4.1 .2

LMFBR/LWR, U-Pu Coprocessed, Contaminated, and Recycled--0xide Fuel

Level 1

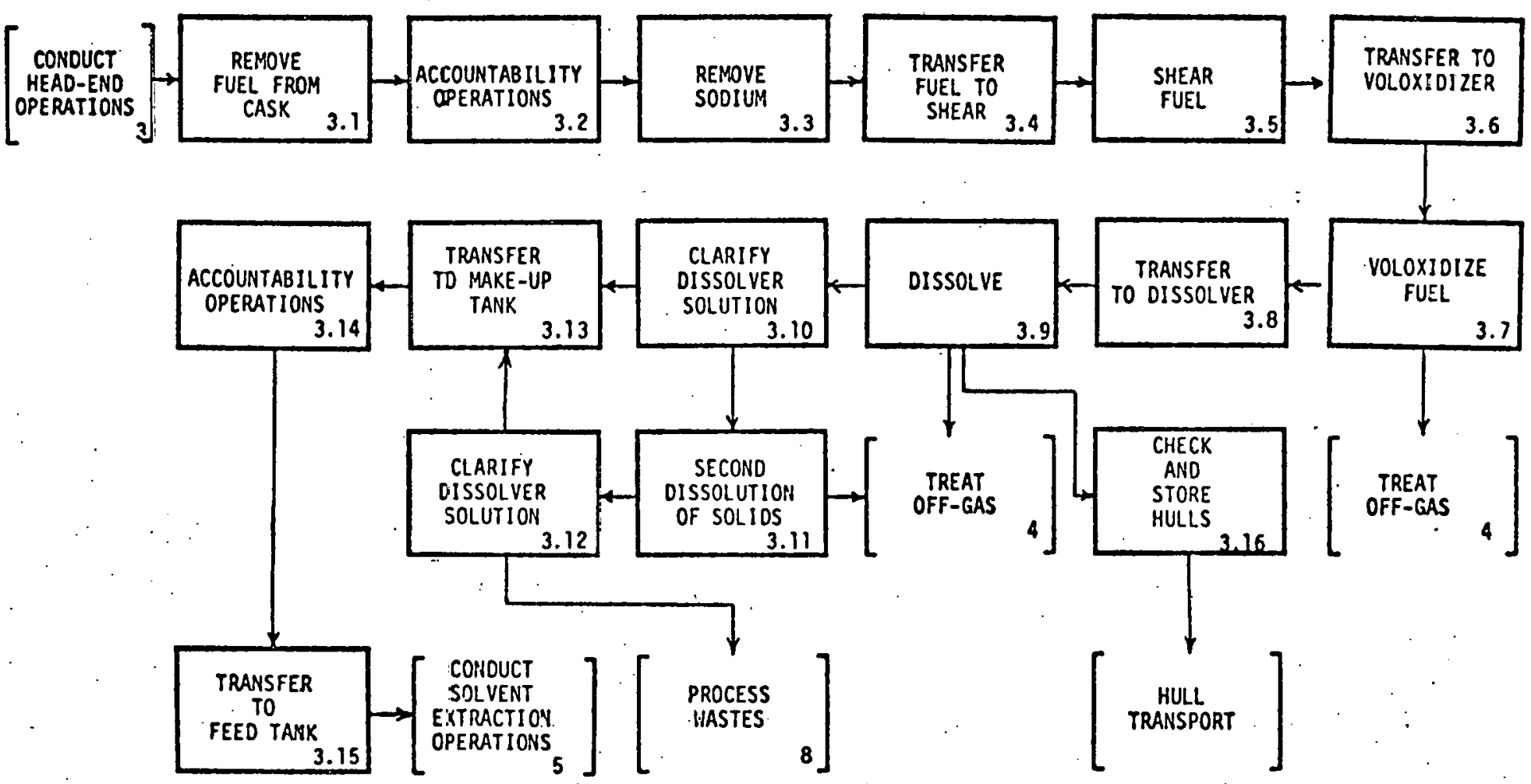


Option 4.1 .2

LMFBR/LWR, U-PU coprocessed, Contaminated, and Recjcled--Dxide Fuel

Leve 1

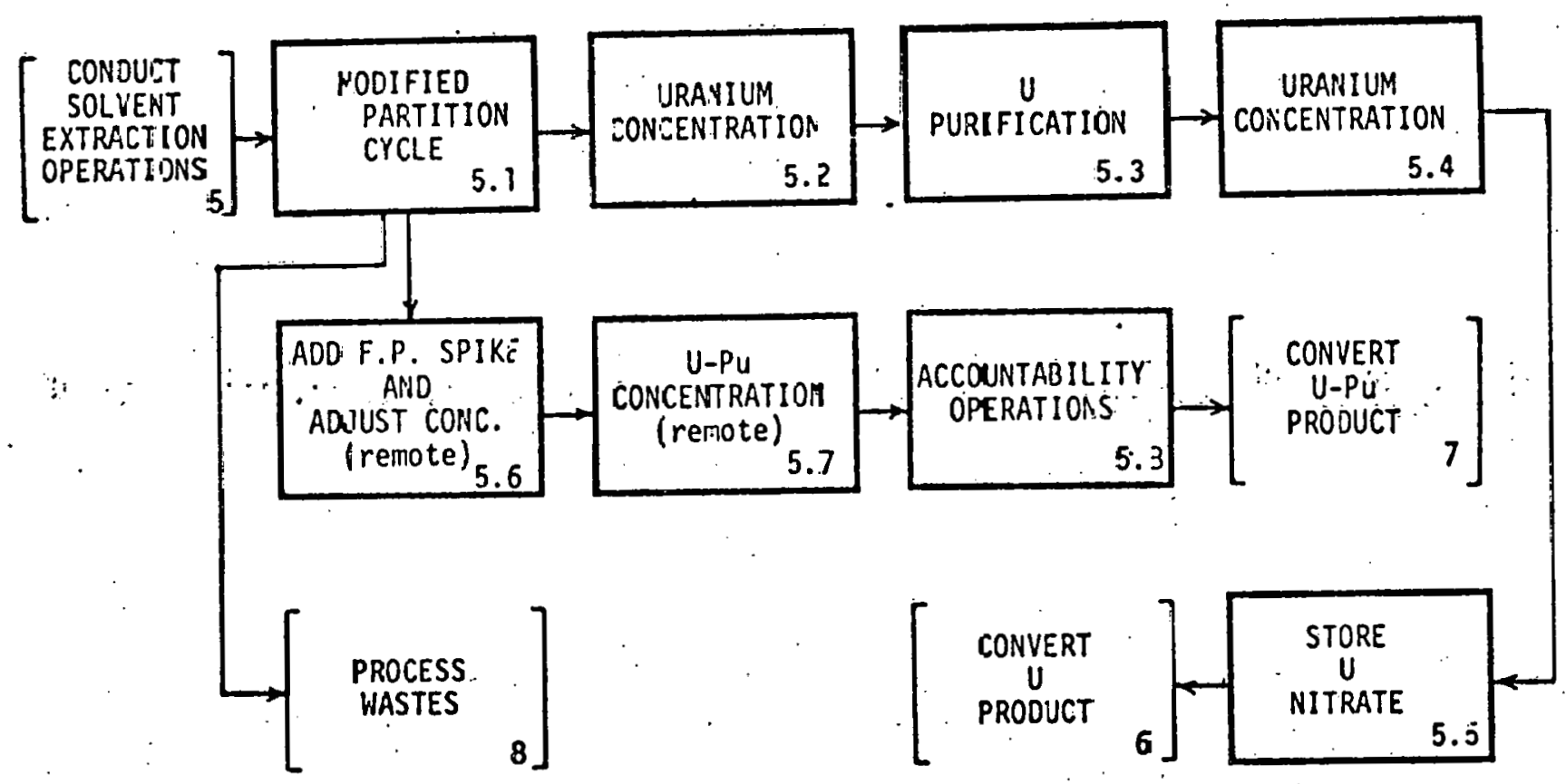


Option 4.1.2

LMFBR/LWR, U-Pu Coprocessed, Contaminated, and Recycled--Oxide Fuel

Level 1

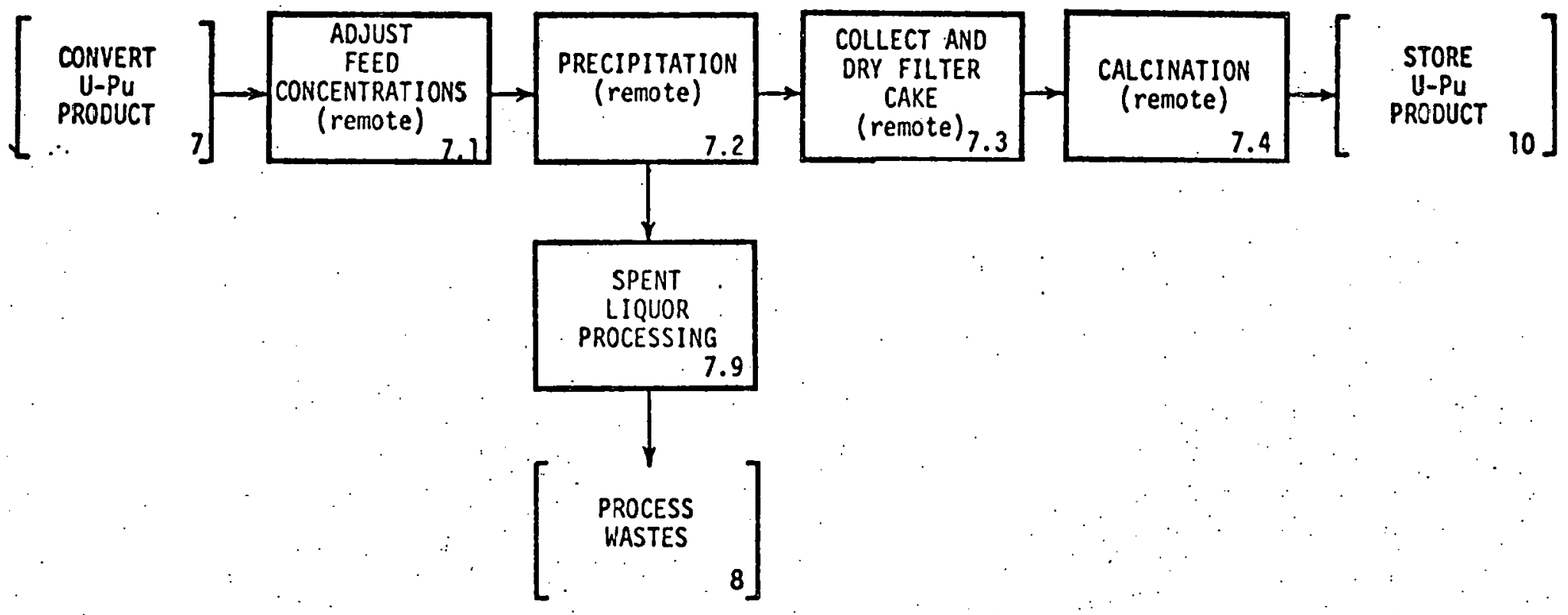


Option 4.1.2 LMEBR,'LUR U-PL Coprocessed, Recy:led Oxide Fuel

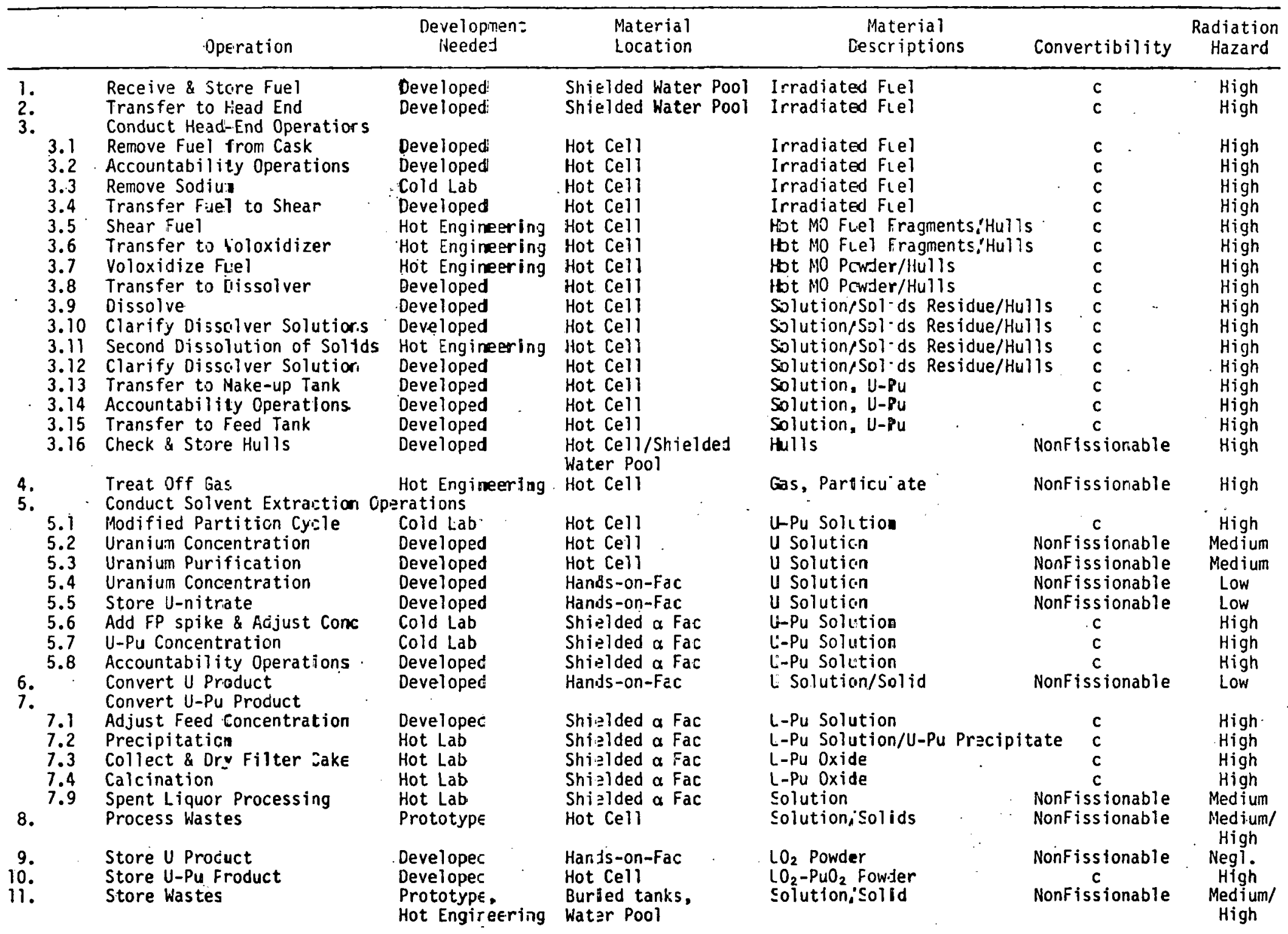


Option 4.1.3 LMMBR/LWR, U/Pu Coprocessed, Contaminated,

Recycled Carbide Fuel

This option is similar to option 4.1.2--coprocessing and contamination with fission products--except that the LMFBR core and axial blanket are carbides rather than oxides.

Functional flow diagrams and process rating tables follow for reprocessing and refabrication of LMFBR core and axial blanket.

The LWR assessment is the same as for option 4.1.2; the only change is that during the first period (LMFBR buildup) material from LWR processing is converted to carbide before use in the LMFBR. 
Oftion 4.1 .3

LMFBR/LWR, U-PU Coprccessed, Contaminated, and Fecycled--Carbide Fuel

Level 0

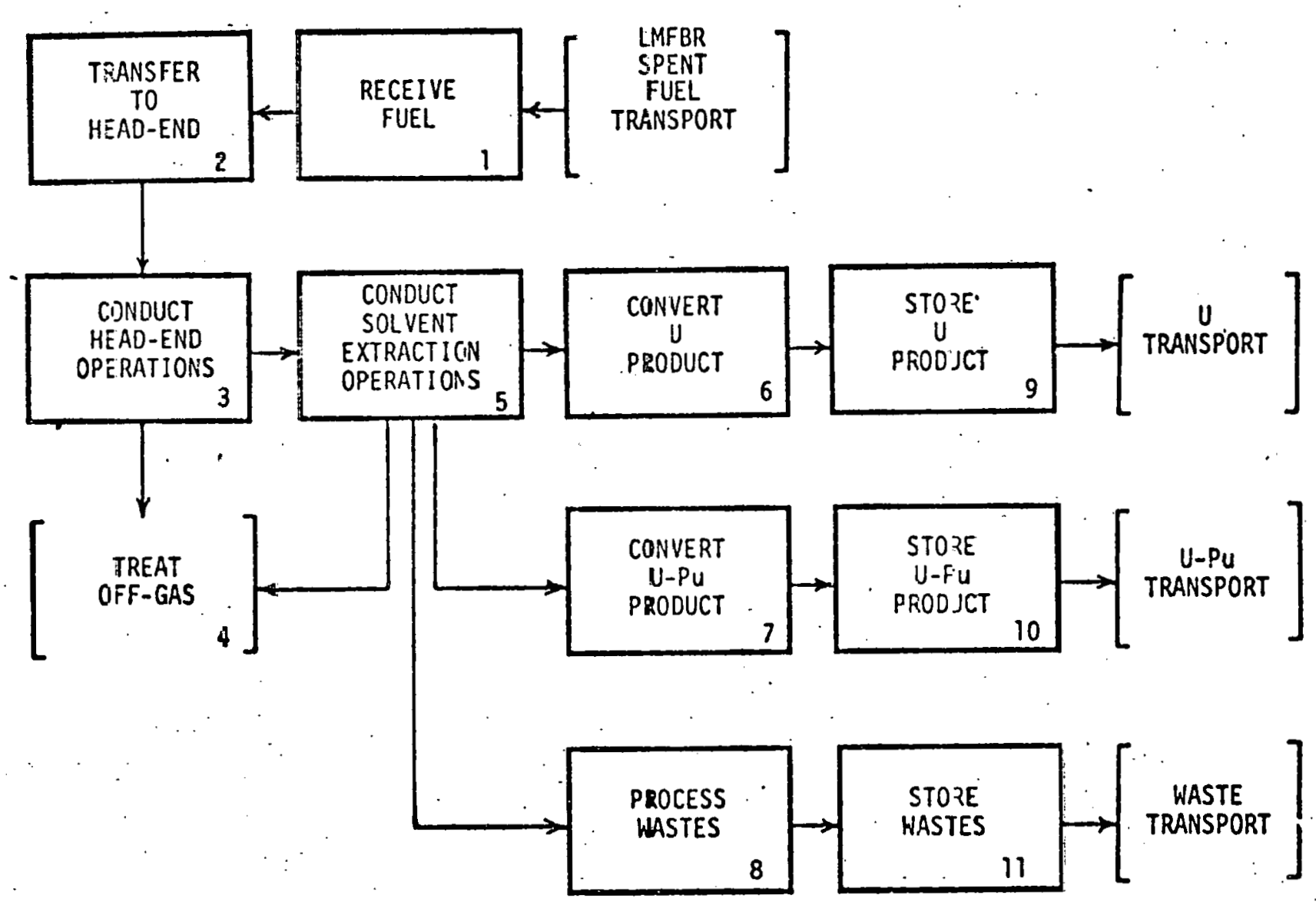


Option 4.1 .3

LMF8R/LWR, U-PU Coprocessed, Contaminated, and Recycled--Carbide Fuel

Level 1

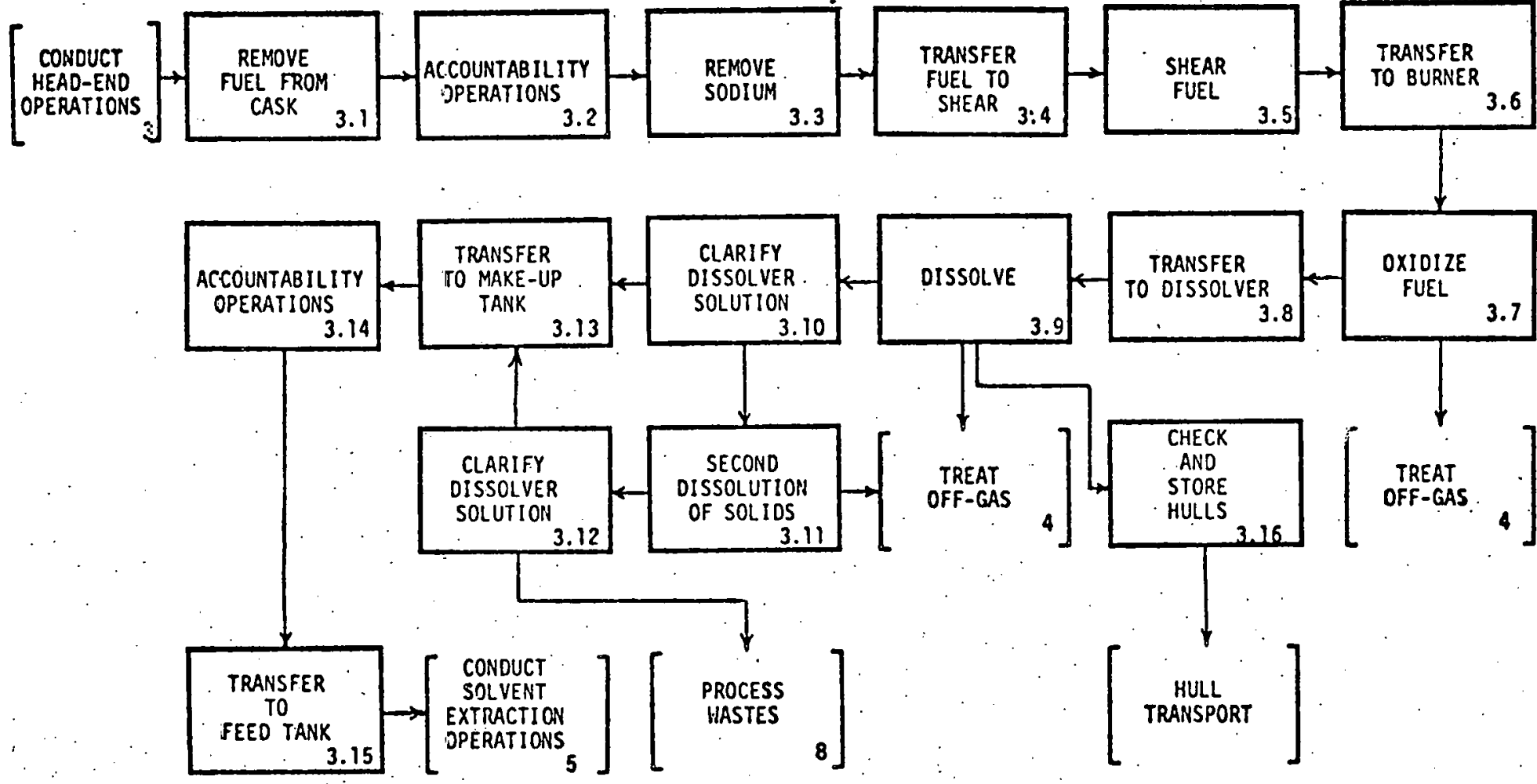




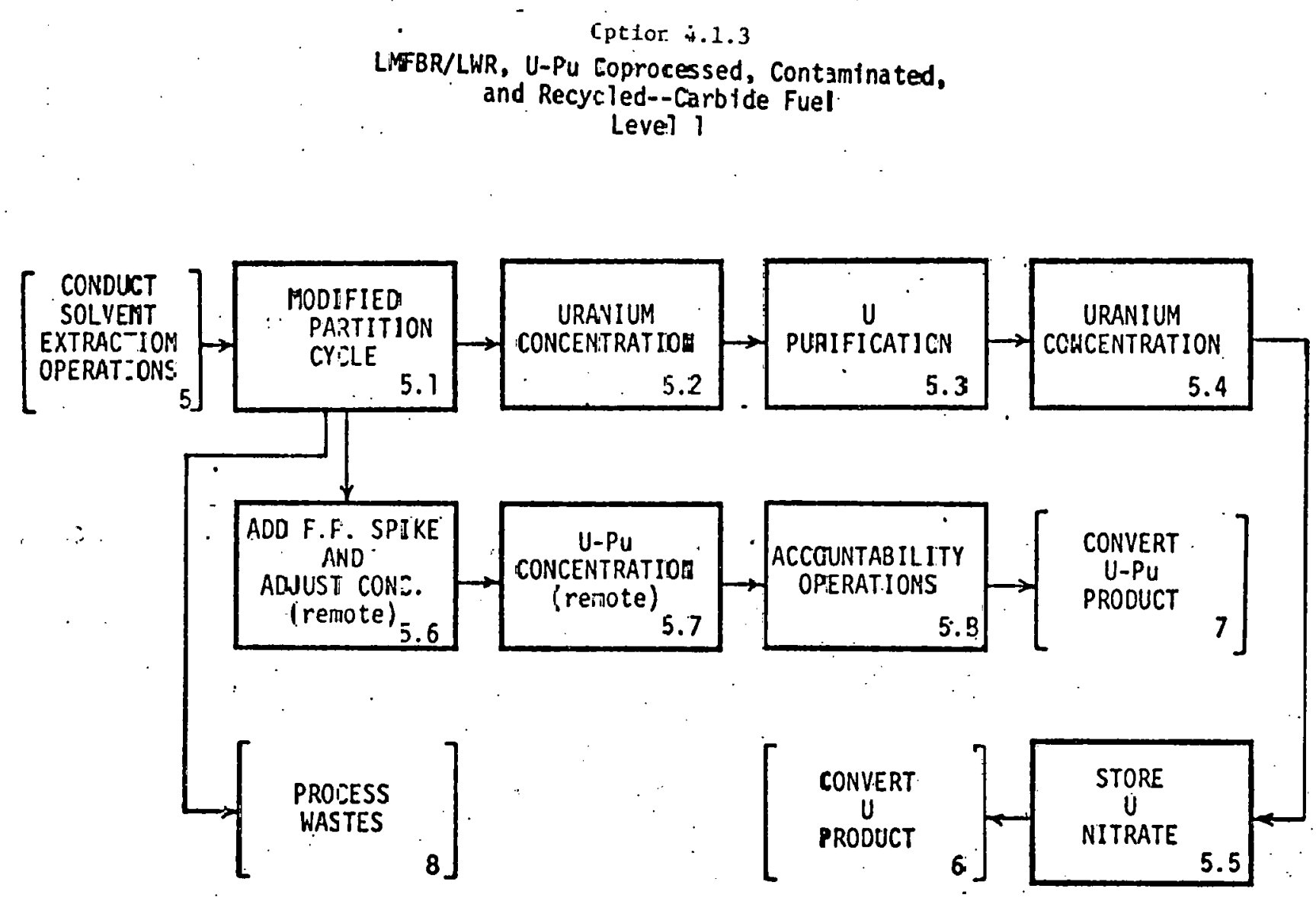


Option 4.1 .3

LMFBR/LWR, U-Pu Coprocessed, Contaminated, and Recycled--Carb1de Fuel

Level 1

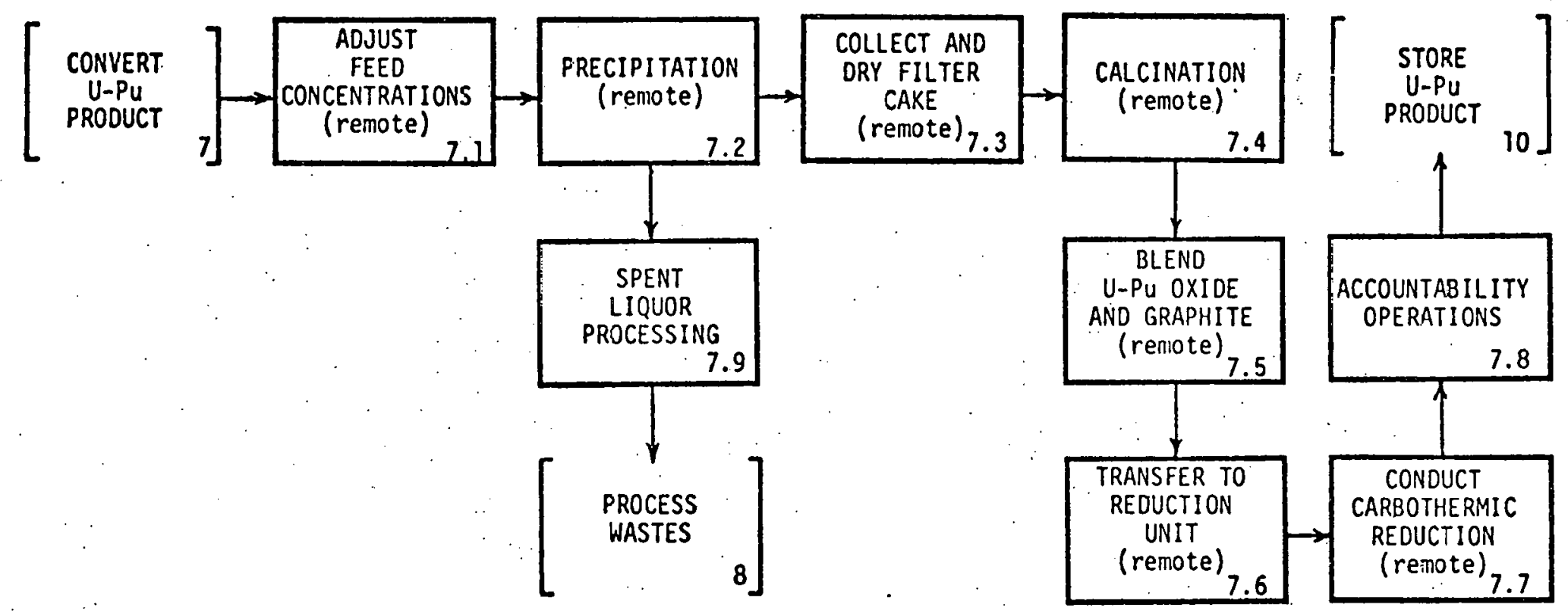


OFtion 4.1.3 LFFER/LWR U/Pu Coprocessed, Recycled Carbide Fuel

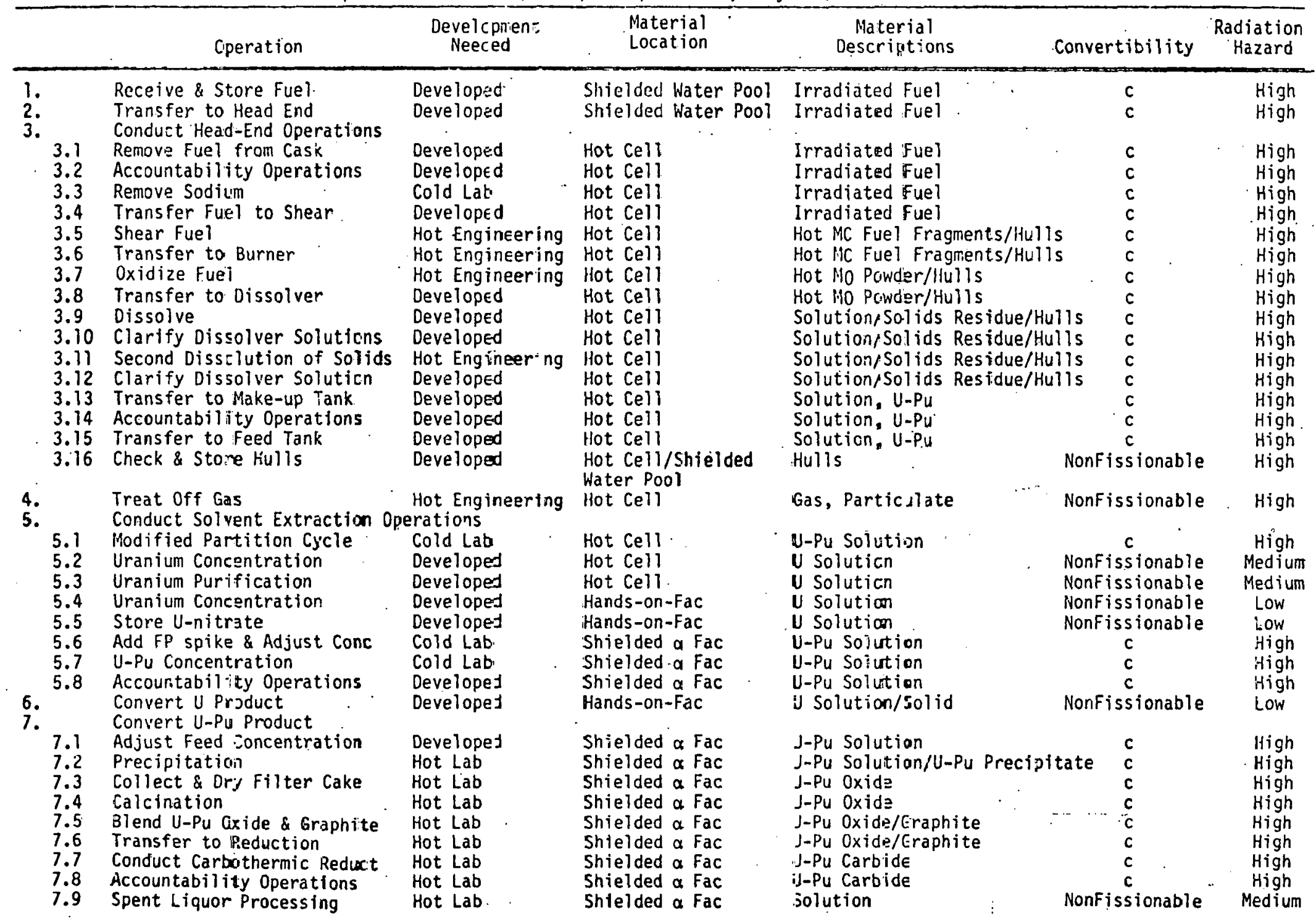


Option 4.1.3 LMFBR/LWR U/Pu Coprocessed, Recycled Carbide. Fuel (Cont'd)

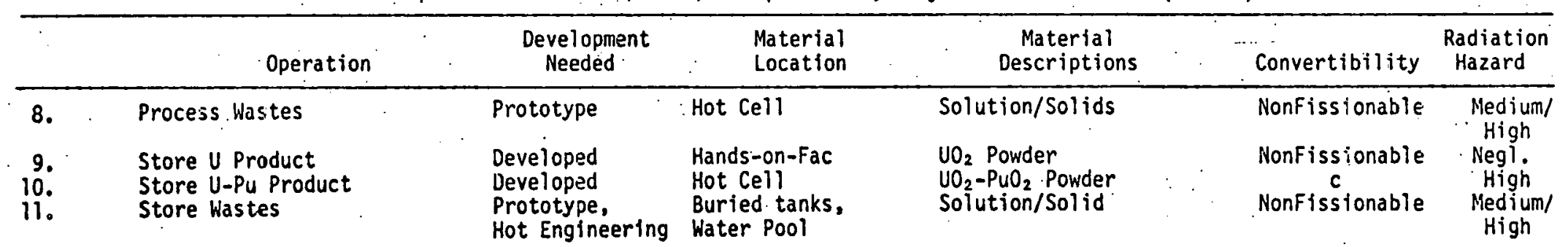


THIS PAGE

\section{WAS INTENTIONALLY \\ LEFT BLANK}


3. FUEL CYCLE EVALUATIONS FOR URANIUM-PLUTONIUM FUELS IN THE LMFBR AND LMFBR/LWR (Hanford Engineering Development Laboratory)
H. C. F. Ripfel
M. J. Barr
S. R. Fields
E. M. Greene
R. L. Plum
D. D. Scott

\subsection{DISCUSSION}

This chapter covers the fabrication of LMFBR fuel for the following cases:

- LMFBR/LWR Standard Recycle - Case 29

- LMFBR/LWR Coprocessed (Contaminated) Oxide - Case 30

- LMFBR/LWR Coprocessed (Contaminated) Carbide - Case 31

o IMFBR With U/Pu Core, Th Blanket, Inside Secure Energy Center; LMFBR With Denatured U Core, Th Blanket, Outside Energy Center Case 66

\subsubsection{IMFBR/LWR Standard Recycle - Case 29}

This alternate using low ( $12 \%) 240 \mathrm{Pu}$ feed is established technology. It is included in the analysis as a "benchmark" case. Cost and process engineering data exist to be used as a baseline for evaluation of other cycles and extension of Case 29 to include the use of high ( $>20 \%) 240 \mathrm{Pu}$ feed. Improvement in the existing proliferation resistance of this case can be obtained through modification of feed materials and process operations and improvements in material accountability and process line concepts.

\subsubsection{LMFBR/LWR Coprocessed (Contaminated) Oxide - Case 30}

This case is differentiated from Case 29 by the inclusion of gamma radioactive materials in the fuel. This ineasure increases proliferation resistance, particularly against diversion by a subnational (terrorist) group. Also, if diversion occurs, the radfoactive "spiking" material hinders subsequent hand1ing and processing of the fuel in the weapon factory. Removal of the spiking material would require use of a shielded chemical processing facility. 
The required level of radioactivity induced by spiking is yet to be determined as is the method of spiking. For the purposes of this study it was arbitrarily assumed that:

o A spikant already existed in incoming Pu or MOX feed.

o The spikant was small quantities $(<0.1 \%)$ and would not adversely affect processing or fuel behavior.

o The spikant would be a high gamma emitter with a half life of about 1 year or more.

- The radiation would be high enough to debilitate diverters with exposure to $1 \mathrm{KG}$ for $1 \mathrm{HR}$.

The impact of spiking on fuel fabrication complexity, equipment requirements, personnel radiation exposure and cost is yet to be determined. The economics of the fuel cycle, although secondary in priority to nonproifferation, may ultimately determine whether the fuel cycle is viable.

\subsubsection{LMFBR/LWR Coprocessed (Contaminated) Carbide - Case 31}

This case is very similar to Case 30 except that it has a very few addiclunal process sleps; e.g., Lle aduilion of a carbothermic reduetion and modified waste recycle process. It has been concluded that the proliferation aspects of these two cases will not differ significantly from each other and the two cases may be combined in this study; $1 . e .$, Case 31 is a "derived case."

\subsubsection{LMFBR With U/Pu Core, Th Blanket, Inside Secure Energy Center;}

LMFBR With Denatured U Core, Th Blanket, Outside Energy Center Case 66

I'he type of fuel used for the core of the "Inside" LMFBR is similar Lo that of Case 29.

It is to be noted that the method of analysis incorporates no way of giving credit to the energy center concept for its antiproliferation value. "Accessibility" refers to the ease or difficulty of access to material usable for fabricating a nuclear weapon. The rating terms suggested by $I$. Spiewak, ORNL, to Saul Strauch, ERDA DNA, in his letter of August 3, 1977 (remote processing cell, hot cell, glovebox, shielded alpha facility and hands-on facility) do not allow consideration of other Important factors such as the level and type of plant safeguard measures and security. 


\subsection{PROLIFERATION RESISTANCE FACTORS AND DEVELOPMENT REQUIREMENTS}

The proliferation resistance factors and development needs for each of the four cases treated in this chapter are shown in Tables 3.1 through -3.4. The rating method-used-was-the-one-described in the introduction to this report.

\subsection{FUNCTIONAL PROCESS FLOW DIAGRAMS}

Level I and Level II functional process flow diagrams for Cases 29 , 30, 31 and 66 are shown in Figures 3.1 through 3.30. A leve1-0 diagram is provided for Case 66 to show how the fuel-fabrication process fits into the rather complex fuel cycle. 
Table 3.1. Case 29, 3.2.3.1, LMFBR I/Pu Recycle

(Reference Case) Fuel Fabricatior.

\begin{tabular}{|c|c|c|c|c|c|c|}
\hline $\begin{array}{c}\text { Process } \\
\text { Step } \\
\end{array}$ & Operation & Material Description & $\begin{array}{c}\text { Development } \\
\text { Needed }\end{array}$ & $\begin{array}{l}\text { Materlal } \\
\text { Location } \\
\end{array}$ & Convertlbility & $\begin{array}{c}\text { Radiation } \\
\text { Hazard }\end{array}$ \\
\hline 1. & Feed Material. & $\mathrm{UO}_{2}, \mathrm{PuO}_{2}$ and $\mathrm{MOX}$ powder & Some非 & Glovebox & d* & Low ${ }^{+}$ \\
\hline 2. & $\begin{array}{l}\text { Fuel } \\
\text { Fabrication }\end{array}$ & MOX powder and pellets & Some非 & Glovebox & d & Low ${ }^{+}$ \\
\hline 3. & $\begin{array}{l}\text { Pin } \\
\text { Fatrication }\end{array}$ & MOX peliets and pins & Some非 & Glovebox $\Delta$ & $\mathrm{d}$ & Low' \\
\hline 4. & $\begin{array}{l}\text { Burdle } \\
\text { Assembly }\end{array}$ & MOX pins and assemblies & Moderate" & $\begin{array}{l}\text { Limited Access } \\
\text { Assembly Area }\end{array}$ & $\begin{array}{l}\text { ss } \\
a\end{array}$ & Low' \\
\hline 5. & $\begin{array}{l}\text { Scrap } \\
\text { Recycle }\end{array}$ & $\begin{array}{l}\text { MOX powder and pellets, } \\
\text { solutions of } \mathrm{Pu} \text { and } U\end{array}$ & Little** & Glovebox & d & Low** \\
\hline 6. & $\begin{array}{l}\text { Waste } \\
\text { Reprocess }\end{array}$ & $\begin{array}{l}\text { Solid and liquid wastes } \\
\text { containing low-level } \mathrm{Pu} \\
\text { and } \mathrm{U} \text { contamination }\end{array}$ & Little** & Glovebox & $d$ & Low** \\
\hline
\end{tabular}

(非) Processes are currently used in industry with low (n12\%) ${ }^{240} \mathrm{Pu}$ material. Hot prototype needed for adtomated operation and use of ${ }^{233} \mathrm{U}$ or high $(>20 \%){ }^{240} \mathrm{Pu}$.

(*) $\mathrm{UO}_{2}$ is nonfissicnable.

(t) Negliglble for rornal or depleted $\mathrm{UO}_{2}$. May be higher for ${ }^{23} \mathrm{UO}_{2}$.

$(\Delta)$ Containment with mechanizej/automated cperation.

(**) Fuel containing ${ }^{233} \mathrm{U}$ may need an additional sepazations st $\supseteq p$. 
Table 3.2. Case 30, 3.2.3.2, LMFBR/LWR U/Pu Coprocessed, Contaminated and Recycled Oxide Fuel

\begin{tabular}{|c|c|c|c|c|c|c|}
\hline $\begin{array}{l}\text { Process } \\
\text { Step }\end{array}$ & Operation & Material Description & $\begin{array}{l}\text { Development } \\
\text { Needed }\end{array}$ & $\begin{array}{l}\text { Material } \\
\text { Location }\end{array}$ & Convertibility & $\begin{array}{l}\text { Radiation } \\
\text { Hazard }\end{array}$ \\
\hline 1. & Feed Material & $\begin{array}{l}\mathrm{UO}_{2}, \mathrm{PuO}_{2} \text { and } \mathrm{MOX} \text { powder, } \\
\text { contaminated }\end{array}$ & Hot Lab & Hot cell ${ }^{+}$ & $c^{*}$ & $\begin{array}{l}\text { medium to } \\
\text { high }\end{array}$ \\
\hline 2. & $\begin{array}{l}\text { Fuel } \\
\text { Fabrication }\end{array}$ & $\begin{array}{l}\text { MOX powder and pellets, } \\
\text { contaminated }\end{array}$ & Hot Lab & Hot cell & c & $\begin{array}{l}\text { medium to } \\
\text { high }\end{array}$ \\
\hline 3. & $\begin{array}{l}\text { Pin } \\
\text { Fabrication }\end{array}$ & $\begin{array}{l}\text { MOX pellets and pins, } \\
\text { contaminated }\end{array}$ & Hot Lab & Hot cell & c & $\begin{array}{l}\text { medium to } \\
\text { high }\end{array}$ \\
\hline 4. & $\begin{array}{l}\text { Bundle } \\
\text { Assembly }\end{array}$ & $\begin{array}{l}\text { MOX pins and assemblies, } \\
\text { contaminated }\end{array}$ & Hot Lab & Hot cell & c & $\begin{array}{l}\text { medium to } \\
\text { high }\end{array}$ \\
\hline 5 & Scrap' Reeycle & $\begin{array}{l}\text { MOX powder and pellets, } \\
\text { solutions of } \mathrm{Pu} \text { and } \mathrm{U} \text {, } \\
\text { all contaminated }\end{array}$ & $\begin{array}{l}\text { Hot } \\
\text { Engineering }\end{array}$ & Hot cell & c & $\begin{array}{l}\text { medium to } \\
\text { high }\end{array}$ \\
\hline 6. & $\begin{array}{l}\text { Waste } \\
\text { Reprocess }\end{array}$ & $\begin{array}{l}\text { Solid and liquid wastes } \\
\text { containing low-level } \mathrm{Pu} \text {, } \\
\mathrm{U} \text { and contamination }\end{array}$ & $\begin{array}{l}\text { Hot } \\
\text { Engineering }\end{array}$ & Hot cell & c & $\begin{array}{l}\text { medium to } \\
\text { high }\end{array}$ \\
\hline
\end{tabular}

(t) Containment including local shielding with automated operation.

(*) $\mathrm{UO}_{2}$ is nonfissionable. 
Table 3.3. Case 31, 3.2.3.2, LMFBR/LWR U/Pu Coprocessed, Contaminated and Recycled Carbide Fuel

\begin{tabular}{|c|c|c|c|c|c|c|}
\hline $\begin{array}{l}\text { Process } \\
\text { Step }\end{array}$ & Operation & Material Descript:̈on & $\begin{array}{l}\text { Derelopment } \\
\text { Needed }\end{array}$ & $\begin{array}{l}\text { Material } \\
\text { Location }\end{array}$ & Convertibility & $\begin{array}{l}\text { Radiation } \\
\text { Hazard }\end{array}$ \\
\hline 1. & Feed Material & $\begin{array}{l}\mathrm{UO}_{2}, \mathrm{PuO}_{2}, \mathrm{IJC}, \mathrm{PuC}, \mathrm{MDX} \\
\text { and } \mathrm{MC} \text { powder, } \\
\text { cont }=\text { minated }\end{array}$ & Hot Lab & Hot cell ${ }^{+}$ & $c^{*}$ & medium \\
\hline 2. & $\begin{array}{l}\text { Fue1 } \\
\text { Fabricaticn }\end{array}$ & $\begin{array}{l}\text { MC powder and pellets, } \\
\text { contaminated }\end{array}$ & Hot Lab & Hot cell & c & medium \\
\hline 3. & $\begin{array}{l}\text { Pin } \\
\text { Fabricaticn }\end{array}$ & $\begin{array}{l}\text { MC. } p=11 \text { ets and pins, } \\
\text { cont } \approx \text { minated }\end{array}$ & Hot Lab & Hat cell & c & medium \\
\hline 4. & $\begin{array}{l}\text { Bundle } \\
\text { Assembly }\end{array}$ & $\begin{array}{l}\text { MC pins and assembiies, } \\
\text { contaminated }\end{array}$ & Hot Lab & Hot cell & c & medium \\
\hline 5. & Scrap Recycle & $\begin{array}{l}\text { MOX and MC powder and } \\
\text { pellets, solutions of } \mathrm{Pu} \\
\text { and } \mathrm{I}, \text { all contaninated }\end{array}$ & $\begin{array}{l}\text { Hot } \\
\text { Engineering }\end{array}$ & Hat cell & c & medium \\
\hline 6. & $\begin{array}{l}\text { Waste } \\
\text { Reprocess }\end{array}$ & $\begin{array}{l}\text { Solid and liquid wastes } \\
\text { containing low-level } \mathrm{Pu} \text {, } \\
\mathrm{U} \text { an gamma emitting } \\
\text { contamination }\end{array}$ & $\begin{array}{l}\text { Hot } \\
\text { Engineering }\end{array}$ & Hat cell & c & medium \\
\hline
\end{tabular}

(+) Containment including local shielding vith automated operation.

(*) $\mathrm{UO}_{2}$ and $\mathrm{UC}$ are nonfissionable. 
Table 3.4 Case 66, 3.4.2.6, Energy Center Containing LMFBR with U/Pu Core, Th Blanket Inside, Modified LEU/Th LMFBR Outside. External LMFBR Spent Fuel

Returned to Center for Reprocessing

\begin{tabular}{|c|c|c|c|c|c|c|}
\hline $\begin{array}{c}\text { Process } \\
\text { Step } \\
\end{array}$ & Operation & Material Description & $\begin{array}{c}\text { Development } \\
\text { Needed }\end{array}$ & $\begin{array}{l}\text { Material } \\
\text { Location }\end{array}$ & Sonvertibility & $\begin{array}{c}\text { Radiation } \\
\text { Hazard }\end{array}$ \\
\hline 1. & Feed Material & $\mathrm{UO}_{2}, \mathrm{PuC}_{2}$ and $\mathrm{MOX}$ powder & Some\# & Glovebox $^{\Delta}$ & $d *$ & Low $^{+}$ \\
\hline 2. & $\begin{array}{l}\text { Fuel } \\
\text { Fabrication }\end{array}$ & MOX powder and pellets & Some & Glovebox $^{\Delta}$ & d & Low ${ }^{+}$ \\
\hline 3. & $\begin{array}{l}\text { Pin } \\
\text { Fabrication }\end{array}$ & MOX pellets and pins & Some" & Glovebox ${ }^{\Delta}$ & $d$ & Low't \\
\hline 4. & $\begin{array}{l}\text { Bundle } \\
\text { Assembly }\end{array}$ & MOX pins and assemblies & Moderate\# & $\begin{array}{l}\text { Limited Access } \\
\text { Assembly Area }\end{array}$ & s & Lowt \\
\hline 5. & $\begin{array}{l}\text { Scrap } \\
\text { Recycle }\end{array}$ & $\begin{array}{l}\text { MOX powder and pellets, } \\
\text { solutions of } \mathrm{Pu} \text { and } \mathrm{U}\end{array}$ & Little $e^{* *}$ & Glovebox & $d$ & Low** \\
\hline 6. & $\begin{array}{l}\text { Waste } \\
\text { Reprocess }\end{array}$ & $\begin{array}{l}\text { Solid and liquid wastes } \\
\text { containing low-level } \mathrm{Pu} \\
\text { and } \mathrm{U} \text { contamination }\end{array}$ & L1ttle** & Glovebox & d & Low** \\
\hline
\end{tabular}

(\#) Processes are currently used in industry with $10 \mathrm{w}(\sim 12 \%){ }_{233}^{240} \mathrm{Pu}$ material. Hot prototype needed for automated operation and use of ${ }^{233} \mathrm{U}$ or high $(>20 \%){ }^{240} \mathrm{Pu}$.

(*) $\mathrm{UO}_{2}$ is nonfissionable.

(+) Negligible for normal or depleted $\mathrm{UO}_{2}$. May be higher for ${ }^{233} \mathrm{UO}_{2}$.

$(\Delta)$ Containment with mechanized/automated operation.

(**) Fuel containing ${ }^{233} \mathrm{U}$ may need an additional separations step. 


\section{CASE 29 \\ 3.2.3.1 LMFBR U/Pu RECYCLE (REF CASE)}

FUEL FABRICATION PLANT

LEVEL-1 FUNCTIONAL FLOW DIAGRAM

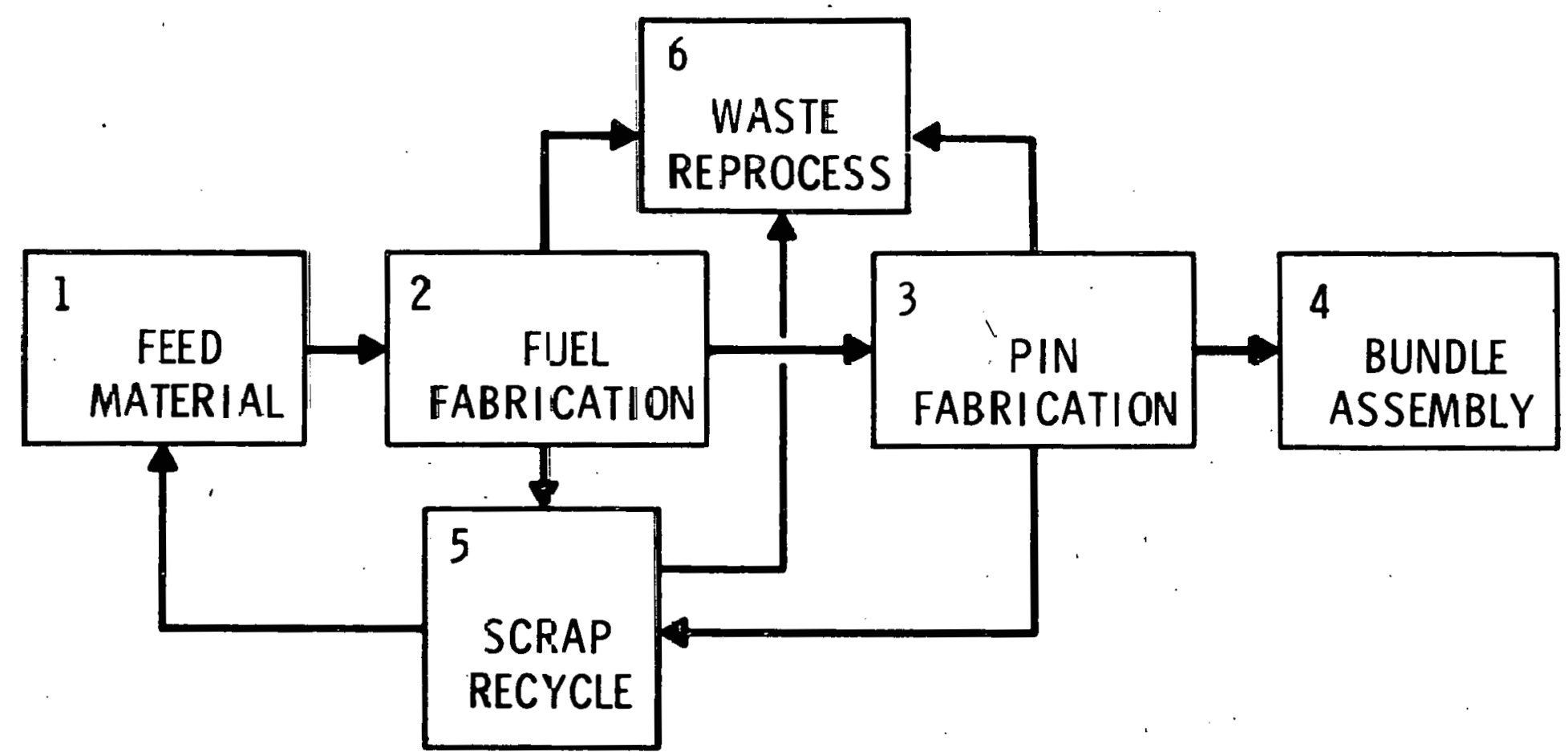

Figure 3.1 
CASE 29

\subsubsection{LMFBR U/Pu (REF. CASE)}

FUEL FABRICATION PLANT

LEVEL-2 FUNCTIONAL FLOW DIAGRAM

1. FEED MATERIAL

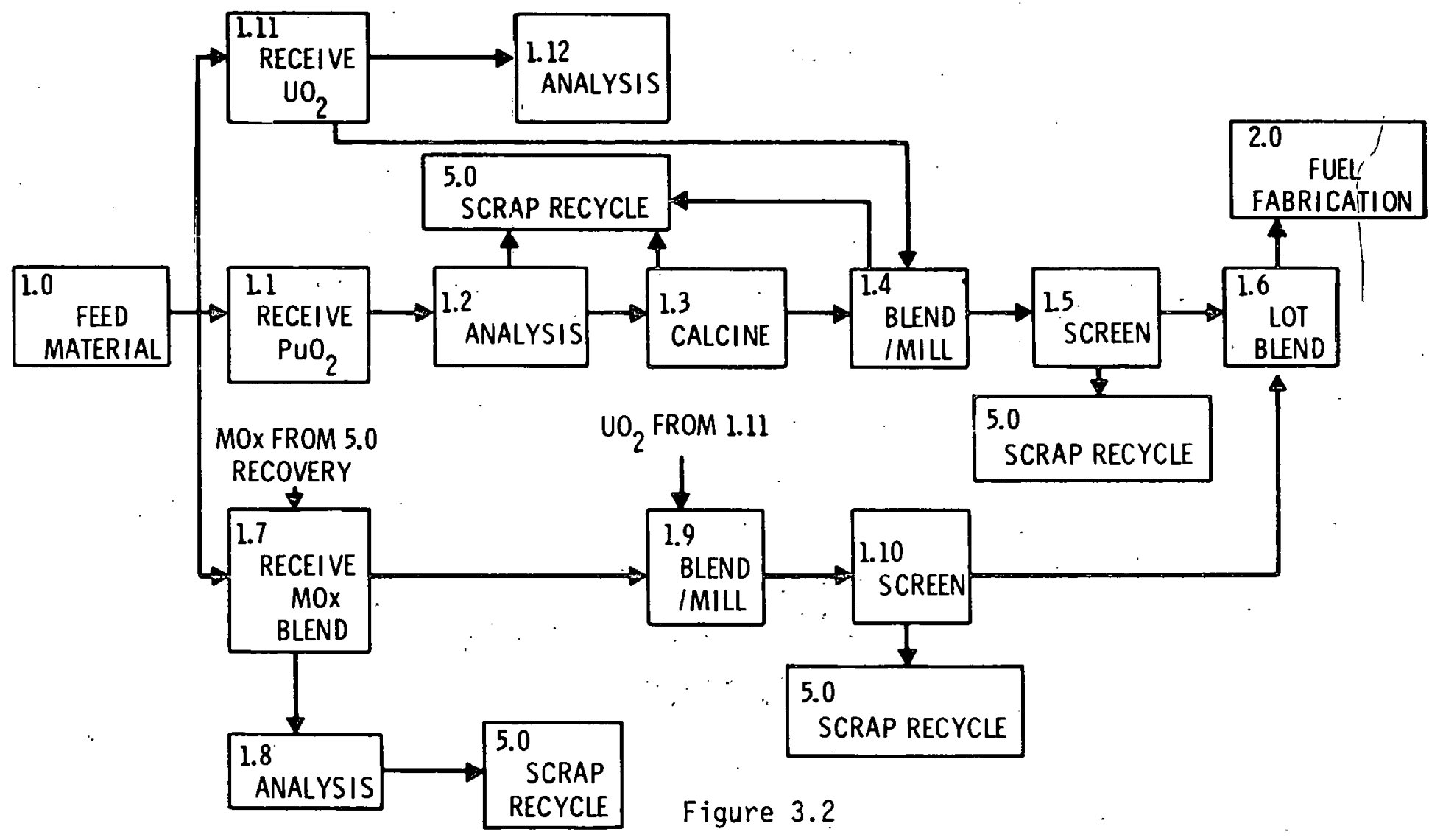


CASE 29

\subsubsection{LMFBR U/Pu (REF CASE)}

FUEL FABRICATION PLANT.

LEVEL-2 FUNCTIONAL FLOW DIAGRAM

2. FUEL FABRICATION

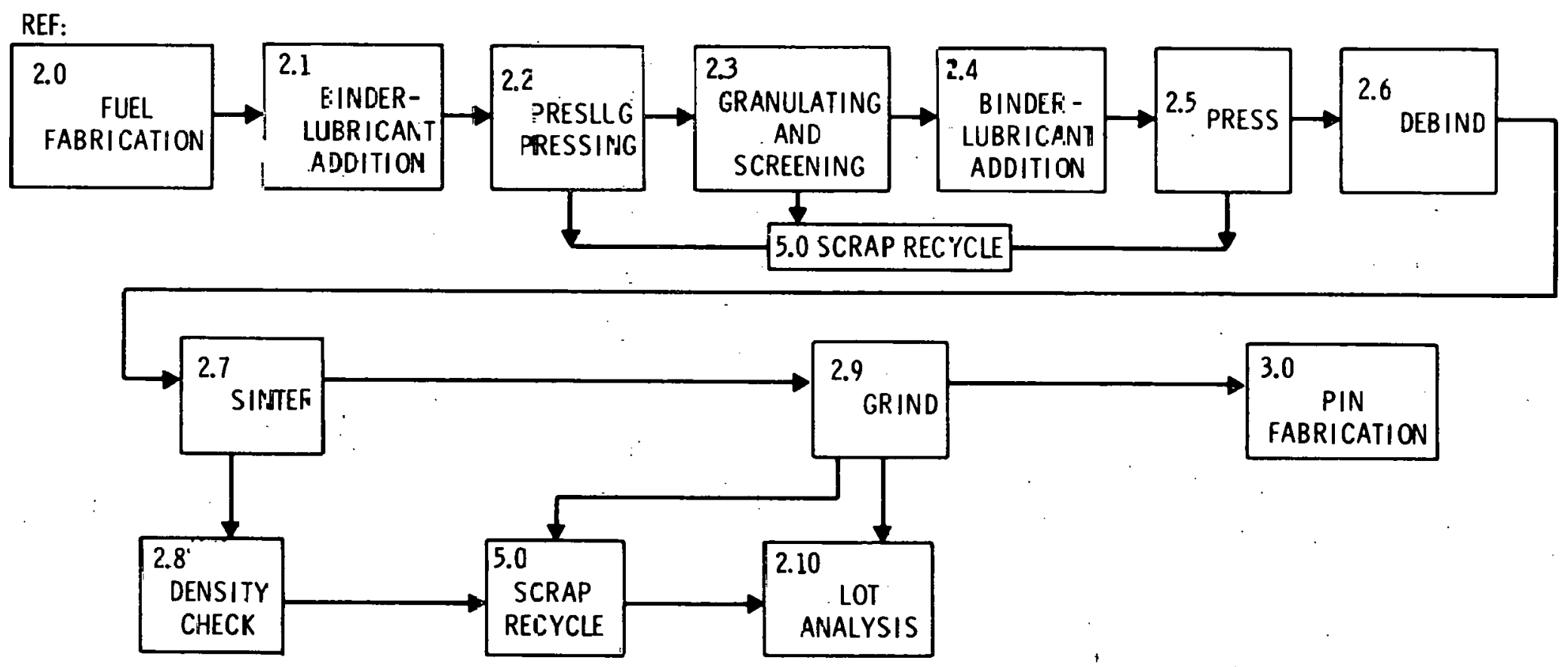

Figure 3.3. 


\section{CASE 29}

\subsubsection{LMFBR U/Pu (REF. CASE)}

FUEL FABRICATION PLANT

LEVEL- 2 FUNCTIONAL FLOW DIAGRAM

3. PIN FABRICATION

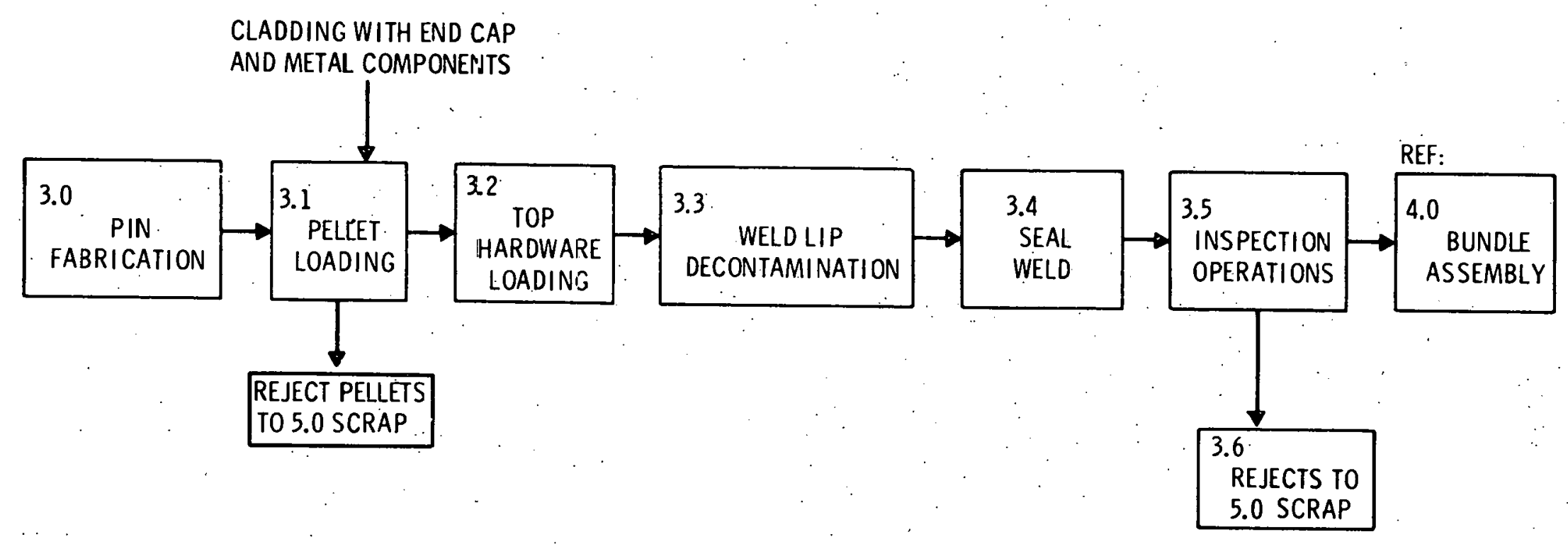




\section{CASE 29}

\subsubsection{LMFBR U/Pu (REF. CASE),}

FUE. FABRICATION PLAN"

LEVEL-2FUNCTIOIJAL FLOW DIf.GRAM

4. BUNDL: ASSEMBLY

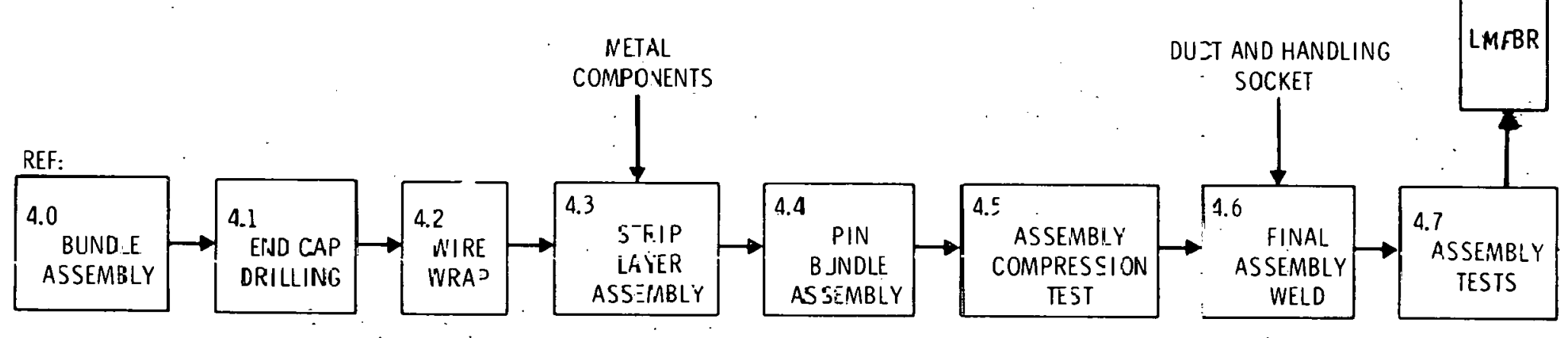

Figure 3.5 


\section{CASE 29 \\ 3.2.3.1 LMFBR U/Pu RECYCLE (REF CASE)}

FUEL FABRICATION PLANT

LEVEL-2 FUNCTIONAL FLOW DIAGRAM

5. SCRAP RECYCLE

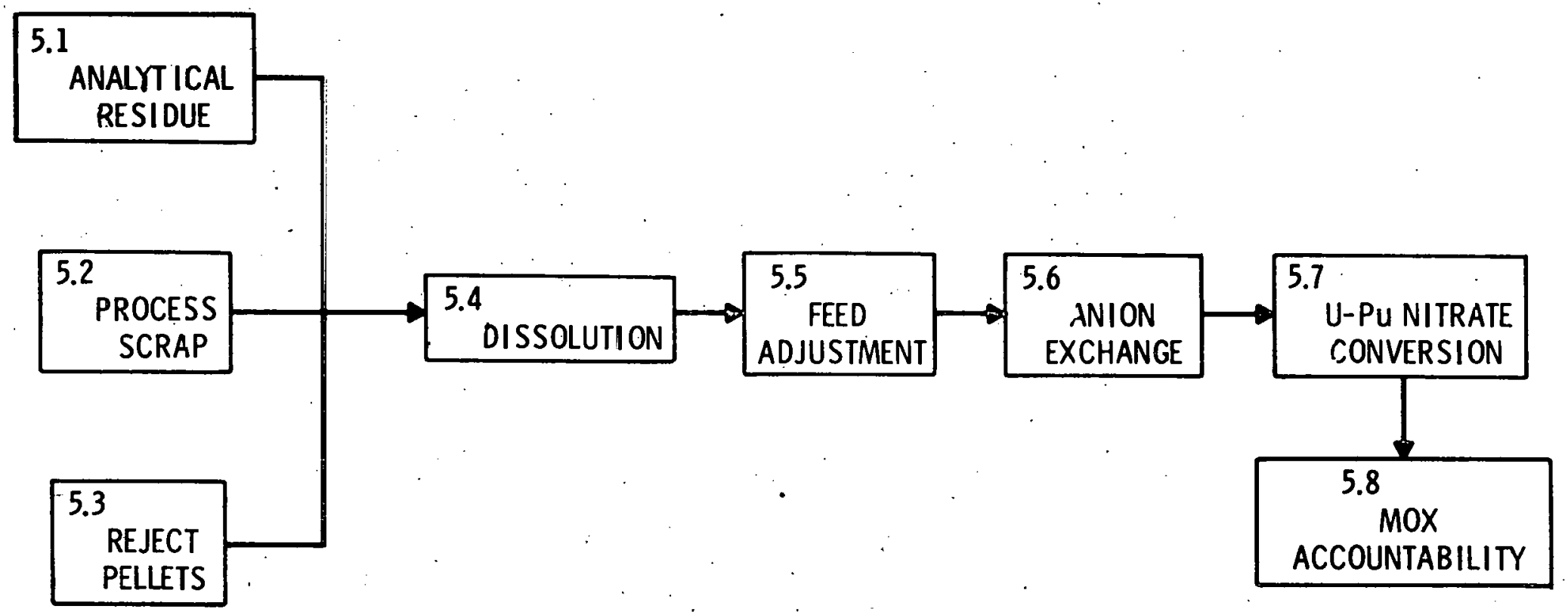

Figure 3.6 


\section{CASE 29 \\ 3.2.3.1 LMFBR U/Pu RECYCLE (REF CASE) AND RECYCLED OXIDE FUEL}

FUEL REFABRICATION

LEVEL-2 FUNCTIONAL FLOW DIAGRAM

6. WASTE REPROCESS

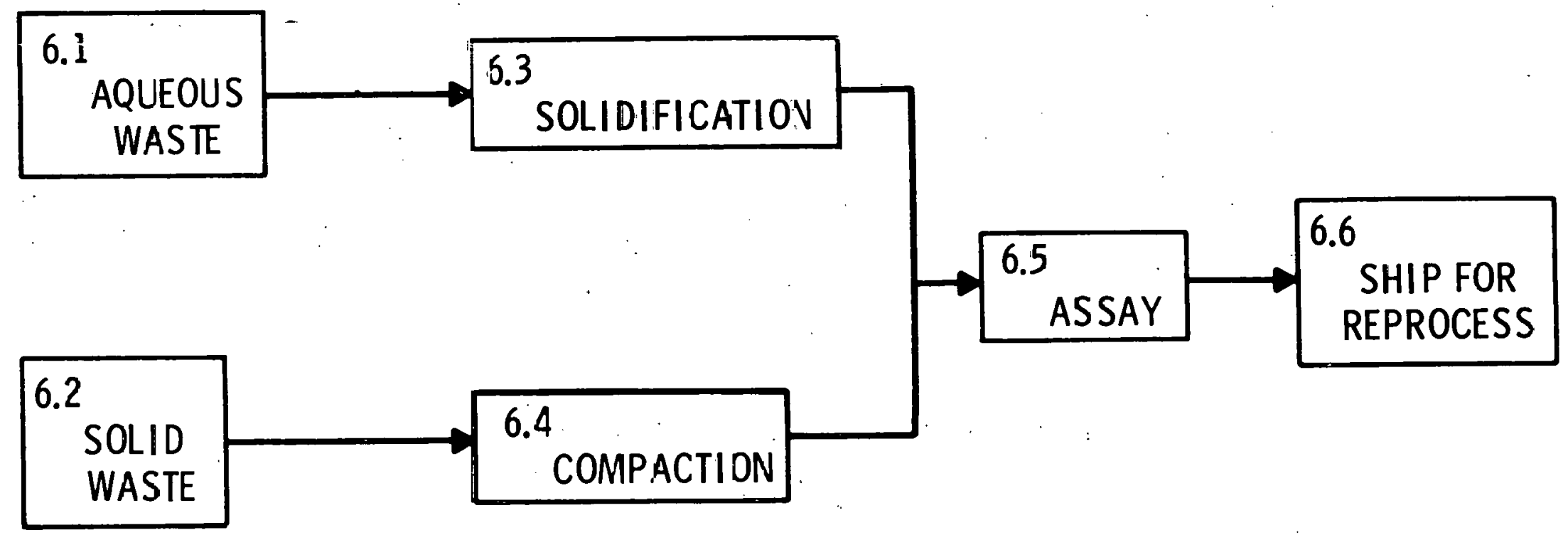

Fi.jure 3.7 
CASE 30

\subsubsection{LMFBR/LWR U/Pu COPROCESSED, CONTAMINATED, AND RECYCLED OXIDE FUEL}

FUEL FABRICATION PLANT

LEVEL-I FUNCTIONAL FLOW DIAGRAM

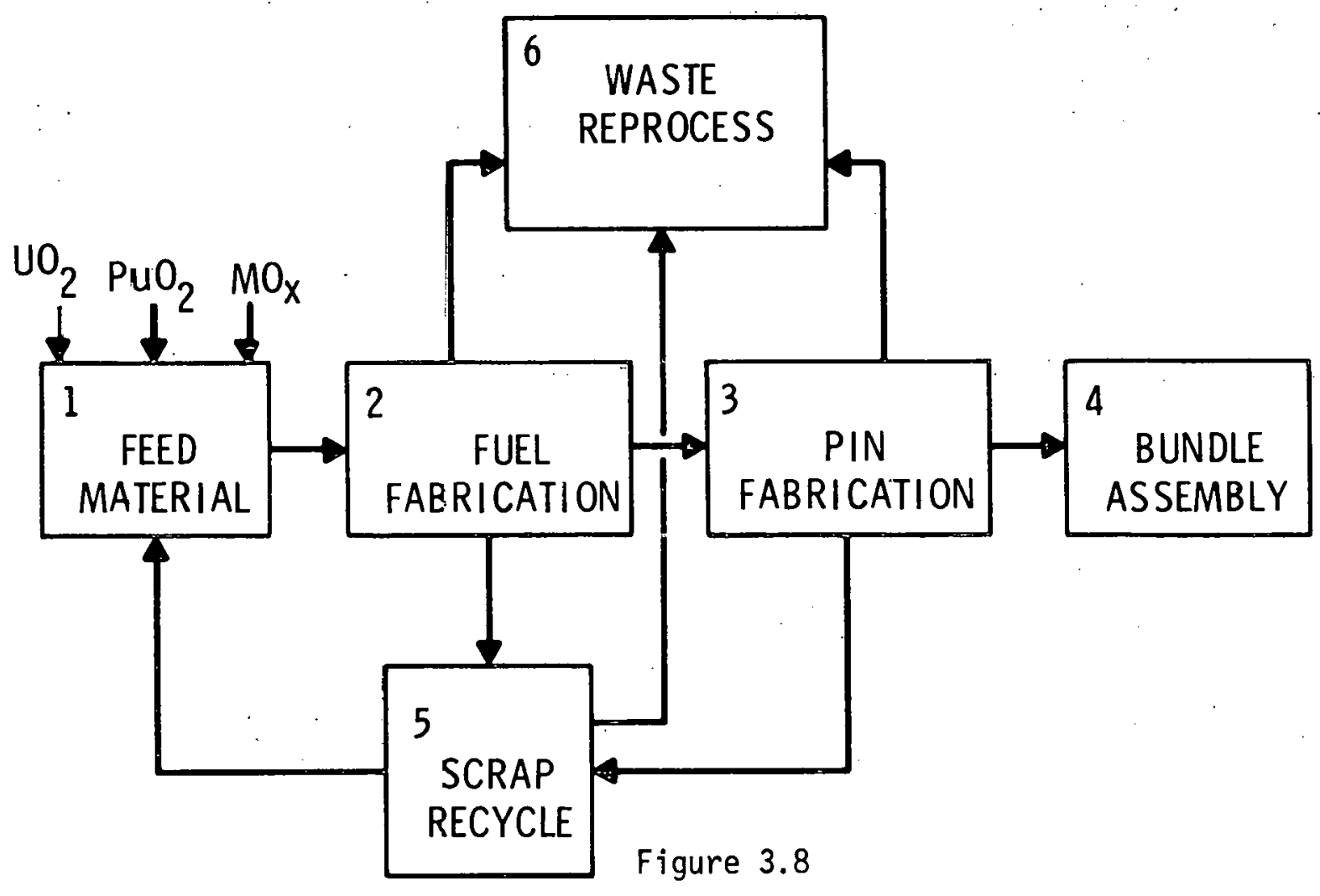




\section{CASE 30}

\subsubsection{LMFBR / LWR U/PU COPROCESSED, CONTAMINATED, AND RECYCLED OXIDE FUEL}

FUELFABRICAIIION PLANT

LEVE-2 FUNCTIONAL FLOW DIAGRAM

1. FEED MATERIAL

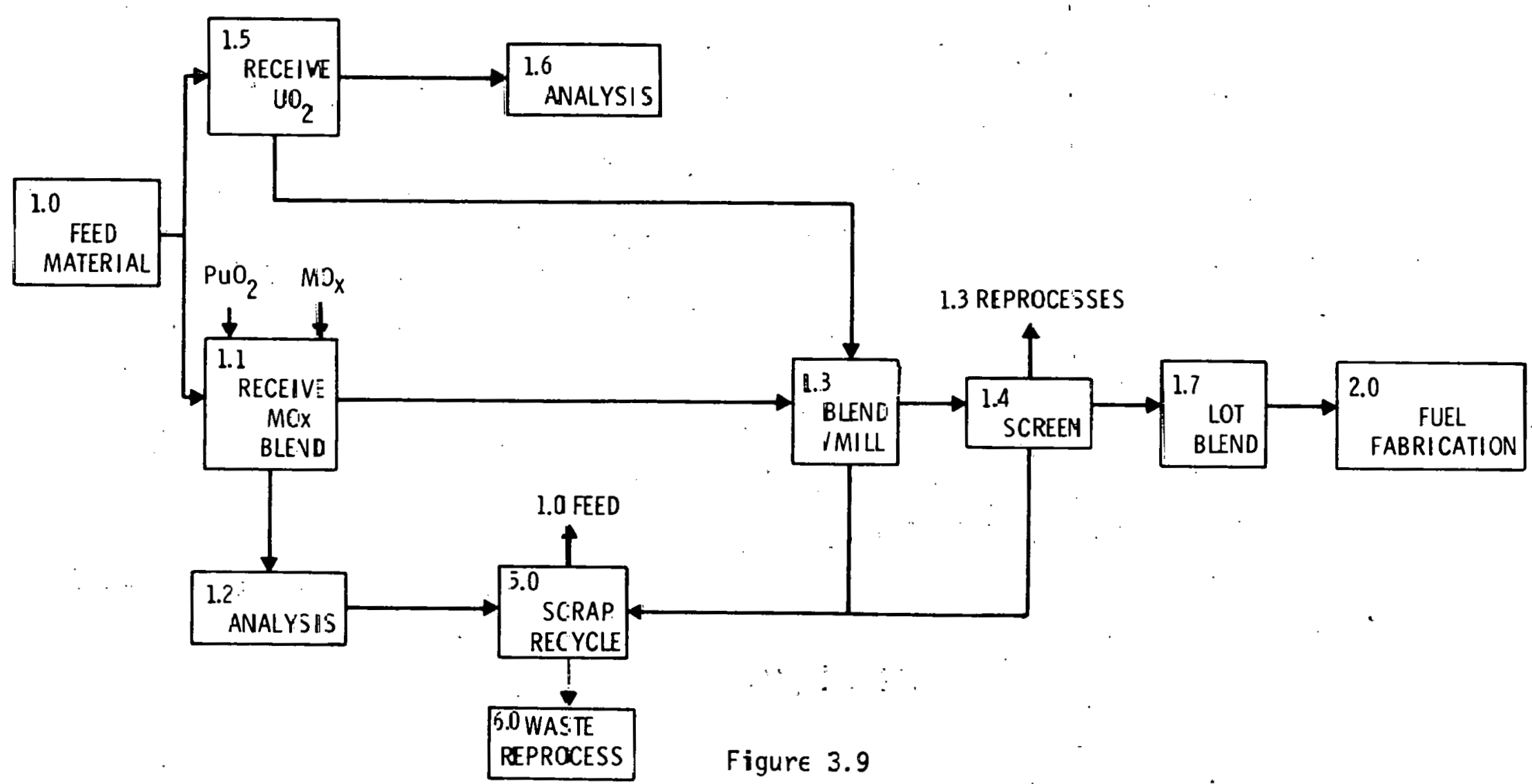




\section{CASE 30 \\ 3.2.3.2 LMFBR /LWR U/PU COPROCESSED, CONTAMINATED, AND RECYCLED OXIDE FUEL}

FUEL FABRICATION PLANT

LEVEL-2 FUNCTIONAL FLOW DIAGRAM

2. FUEL FABRICATION

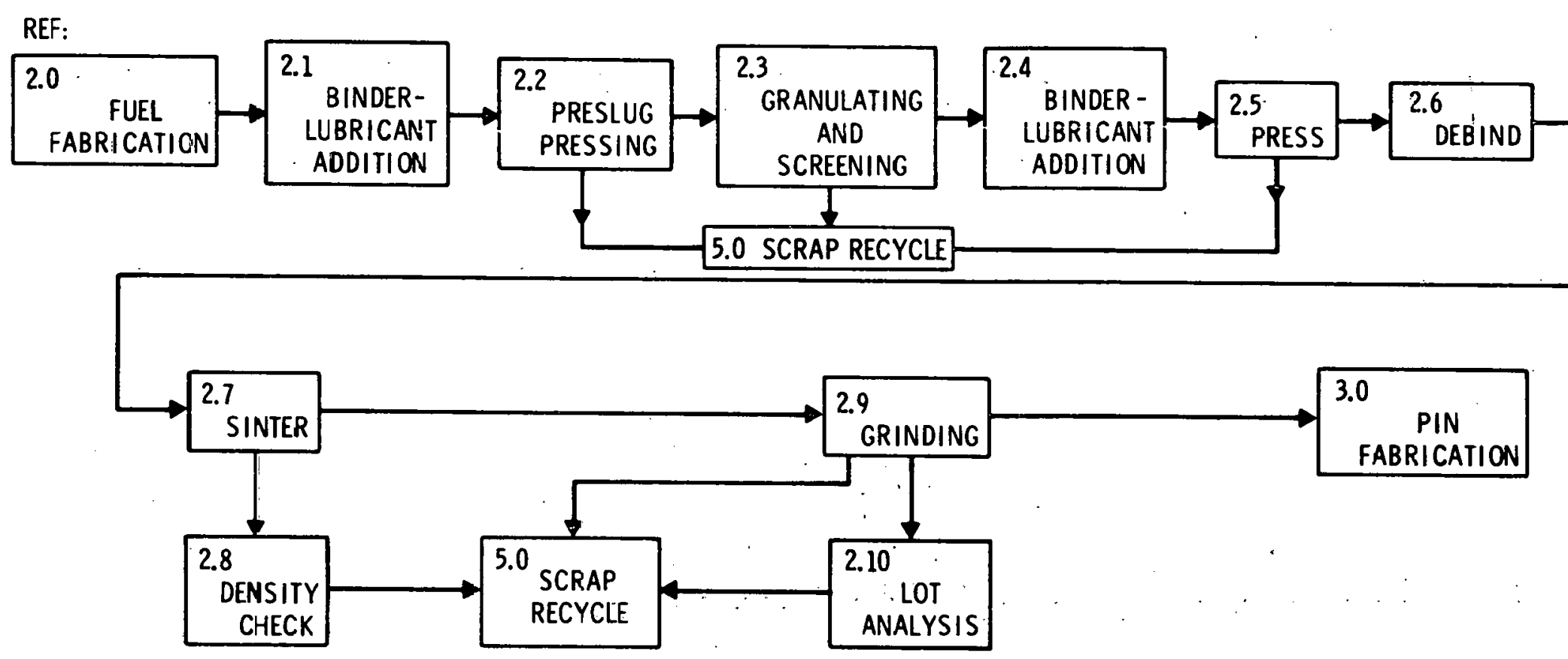

Figure 3.10 


\section{CASE 30}

\subsubsection{LMFBR / LWR U/PU COPROCESSED, CONTAMINATED, AND RECYCLED OXIDE FUEL}

IFUEL FABRICATION PLANT

LEVEL- 2 FUNCTIONAL FLOW DIAGRAM

3. PIN FAERICATION

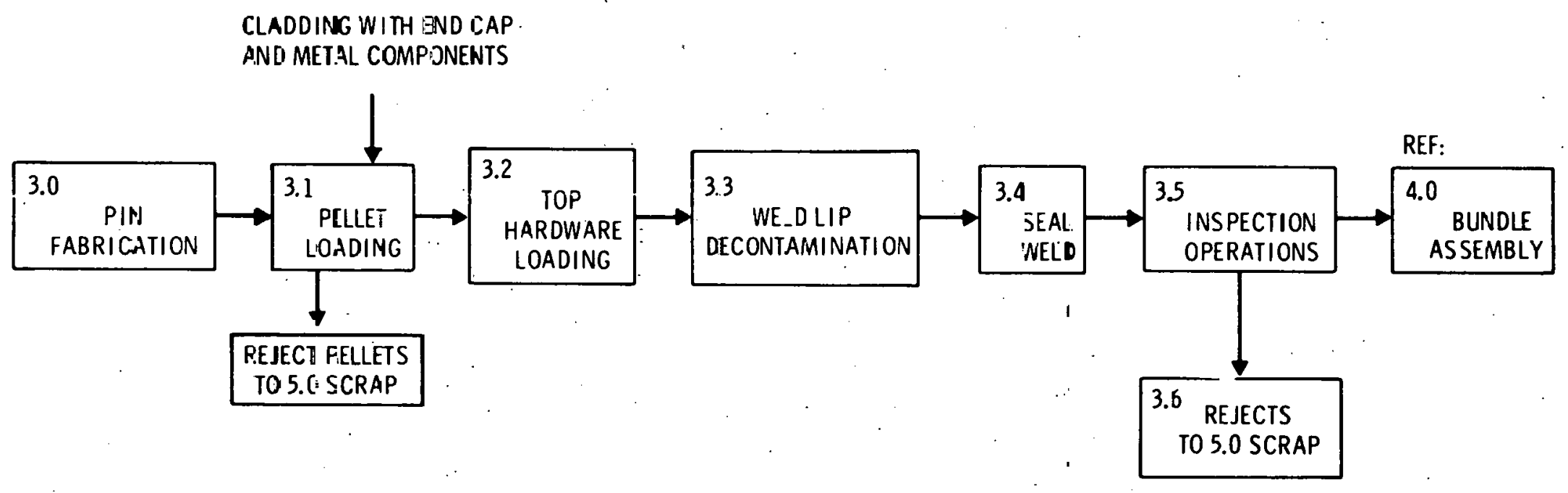

Figure 3.11 


\section{CASE 30 \\ 3.2.3.2 LMFBR / LWR U/PU COPROCESSED, CONTAMINATED, AND RECYCLED OXIDE FUEL}

FUEL REFABRICATION

LEVEL-2 FUNCTIONAL FLOW DIAGRAM

4. BUNDLE ASSEMBLY

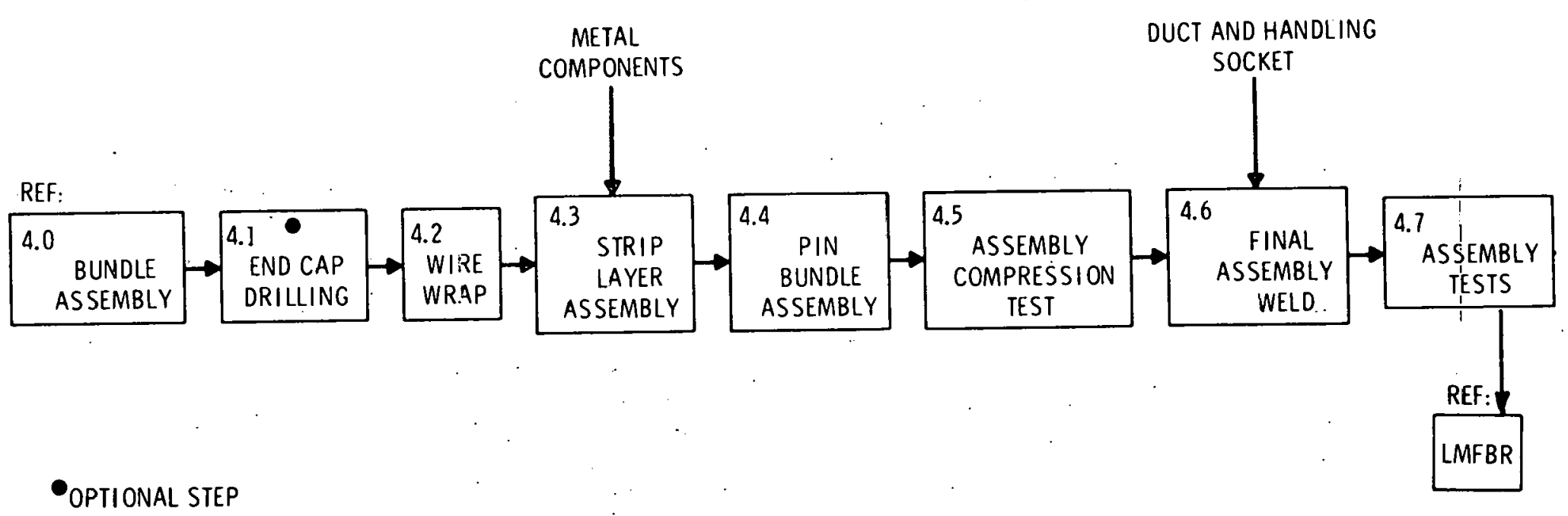




\section{CASE 30}

\subsubsection{LMFBR/LWR U/Pu COPROCESSED, CONTAMINATED, AHD RECYCLED OXIDE FUEL}

FUEL FABRICATION PLANT

LEVEL-2 FUNCTIONAL FLOW DIAGRAM

5. SCRAP RECYCLE

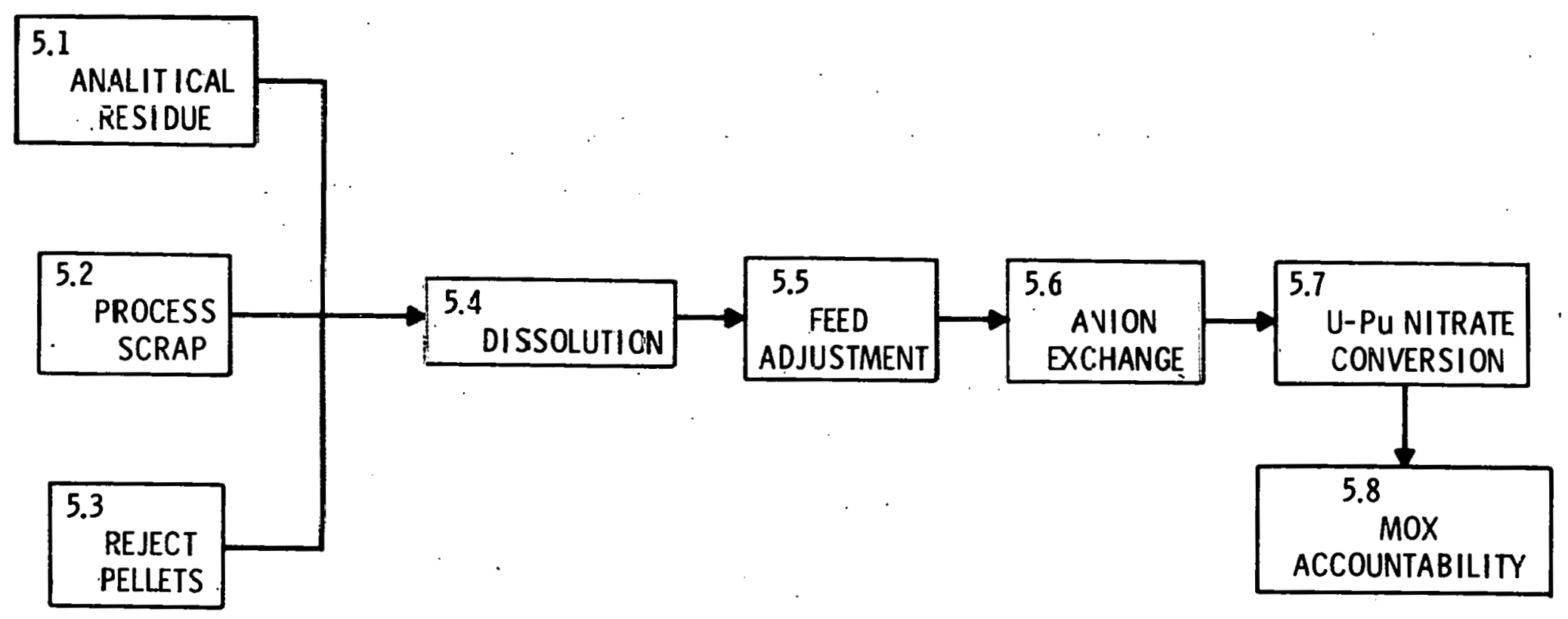

Figure $\Xi .13$ 


\section{CASE 30 \\ 3.2.3.2 LMFBR/LWR U/PU COPROCESSED, CONTAMINATED, AND RECYCLED OXIDE FUEL}

FUEL REFABRICATION

LEVEL-2 FUNCTIONAL FLOW DIAGRAM

6. WASTE REPROCESS

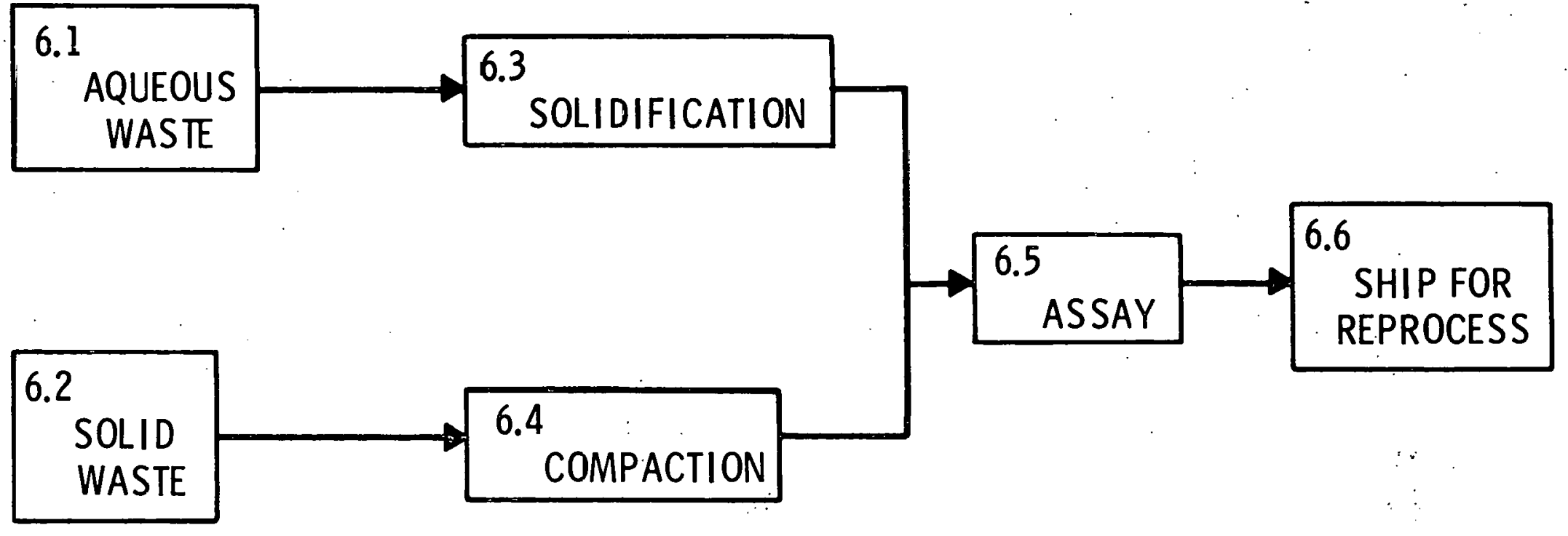




\section{CASE 31 \\ 3.2.3.2 LMFBR /LWR U/Pu COPROCESSED, CONTAMINATED, AND RECYCLED CARBIDE FUEL}

FUEL FABRICATION PLANT

LEVEL-1 FUNCTIONAL FLOW DIAGRAM

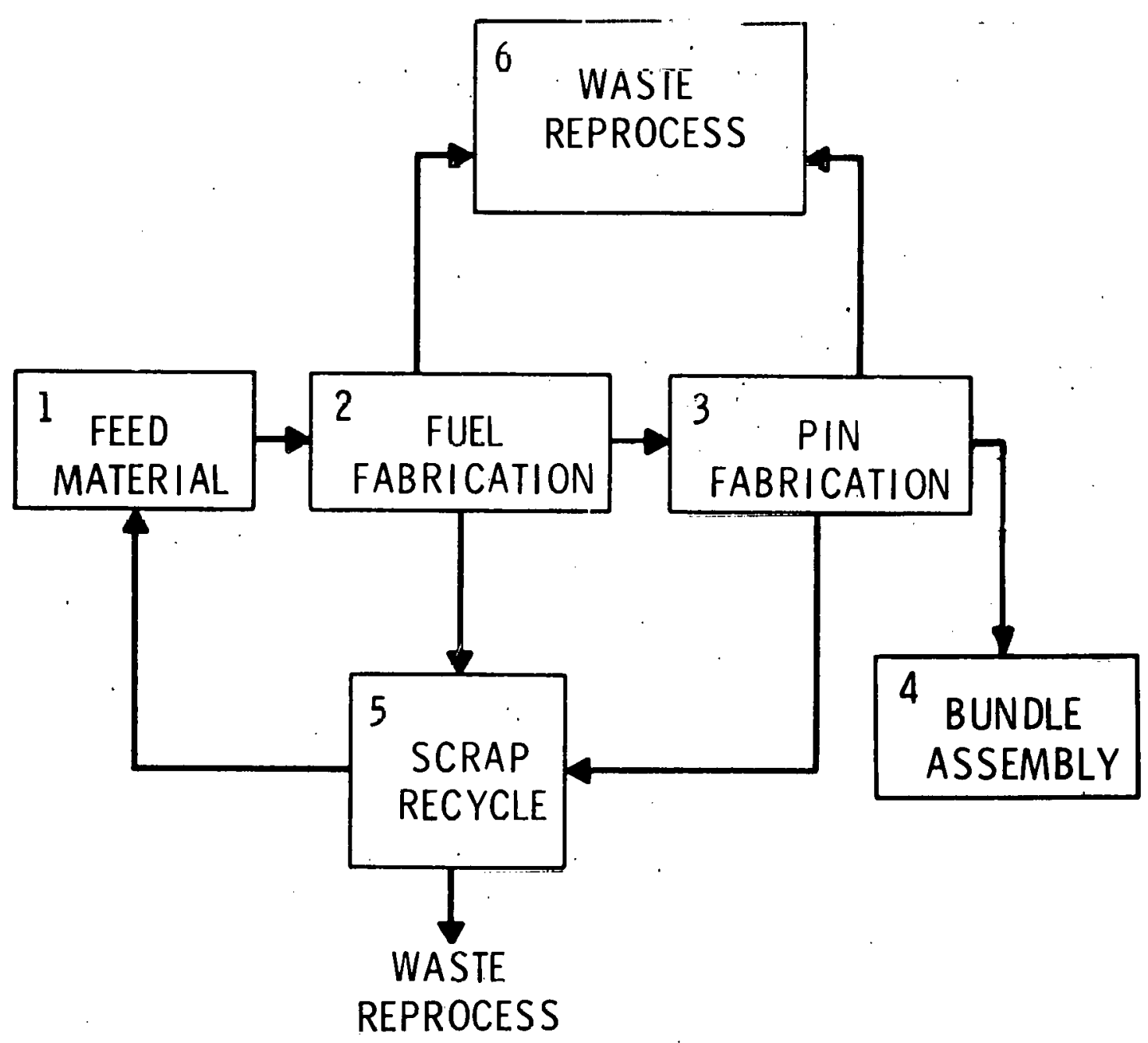

Figure 3.15 
CASE 31 3.2.3.3 LMFBR / LWR U/PU COPROCESSED, CONTAMINATED, AND RECYCLED CARBIDE FUEL

FUEL FABRICATION PLANT

LEVEL-2 FUNCTIONAL FLOW. DIAGRAM

1. FEED MATERIAL

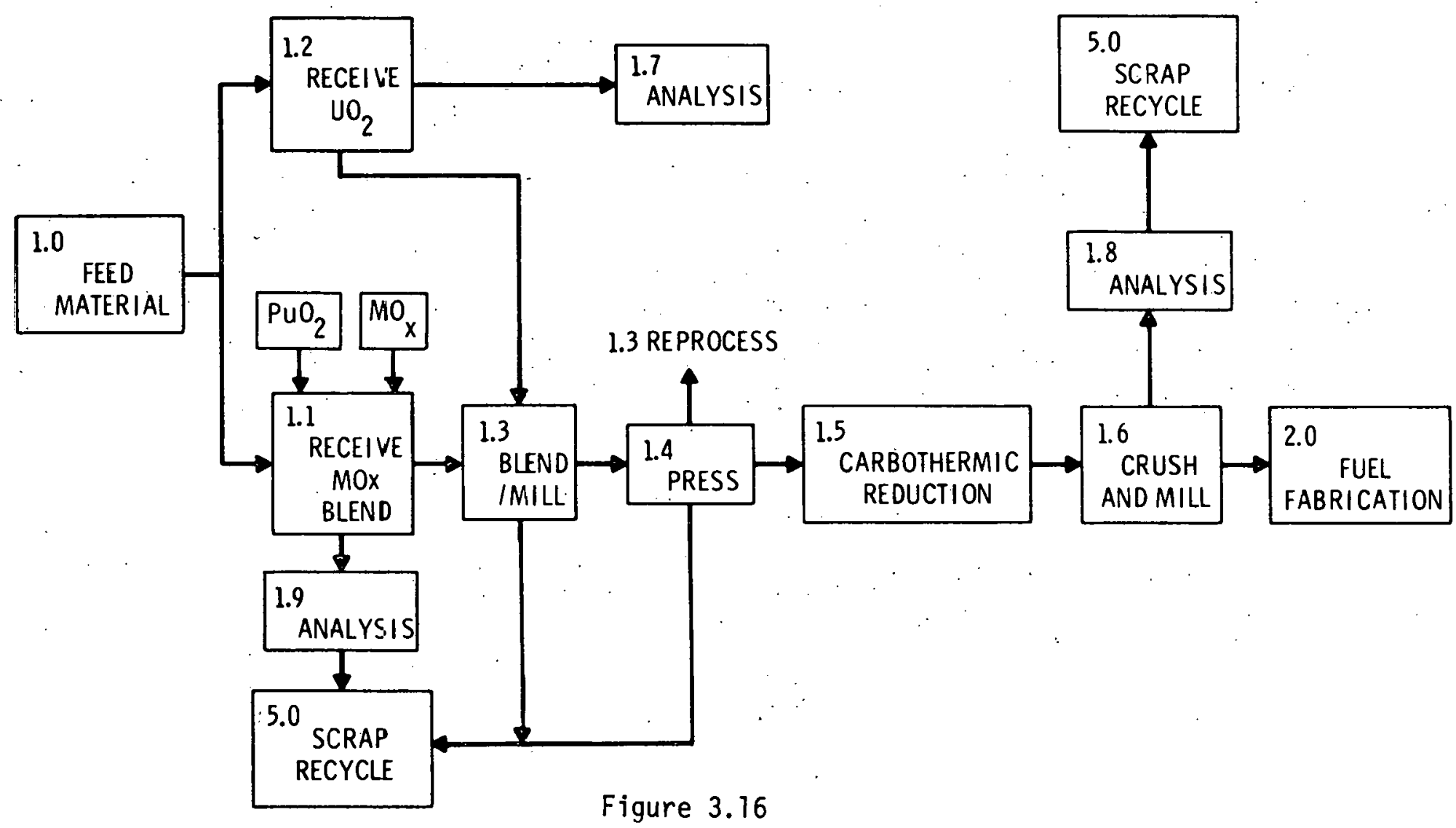




\section{CASE 31 \\ 3.2.3.3 LMFBR/LWR U/PU COPROCESSED, CONTAMINATED, AND RECYCLED CARBIDE FUEL}

FUEL FABRICATION PLANT

LEVEL-2 FUNCTIONAL FLOW DIA'כRAM

2. FUEL FAEFICATION

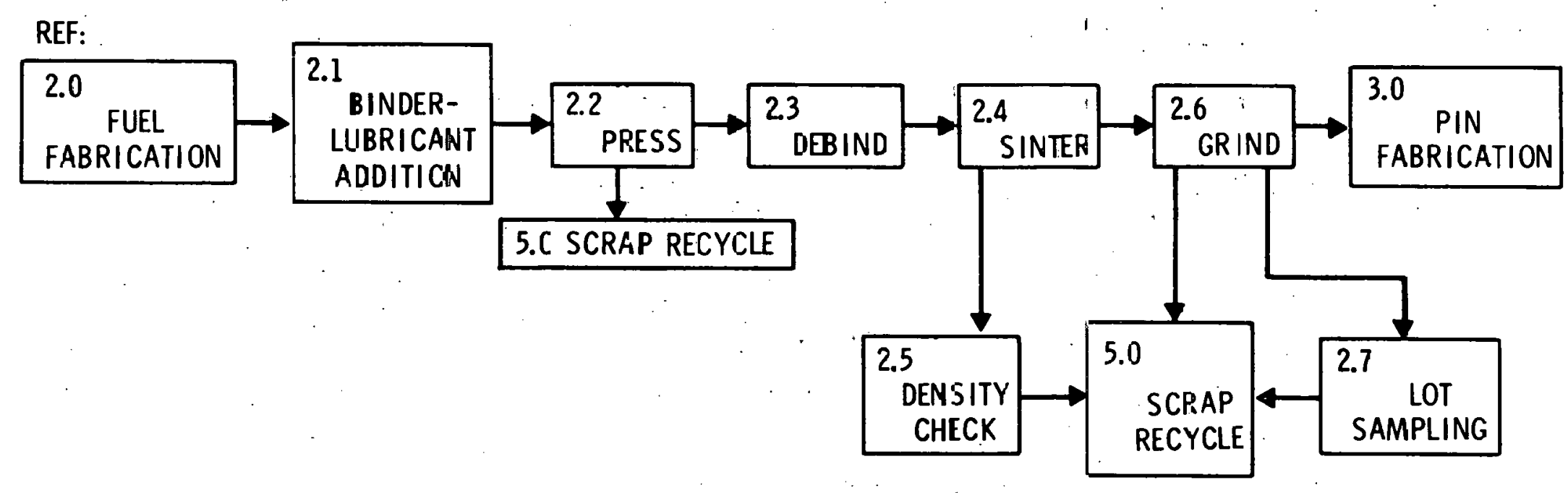

Figure 3.1T. 


\section{CASE 31 \\ 3.2.3.3 LMFBR / LWR U/PU COPROCESSED, CONTAMINATED, AND RECYCLED CARBIDE FUEL}

FUEL FABRICATION PLANT

LEVEL-2 FUNCTIONAL FLOW DIAGRAM

3. PIN FABRICATION

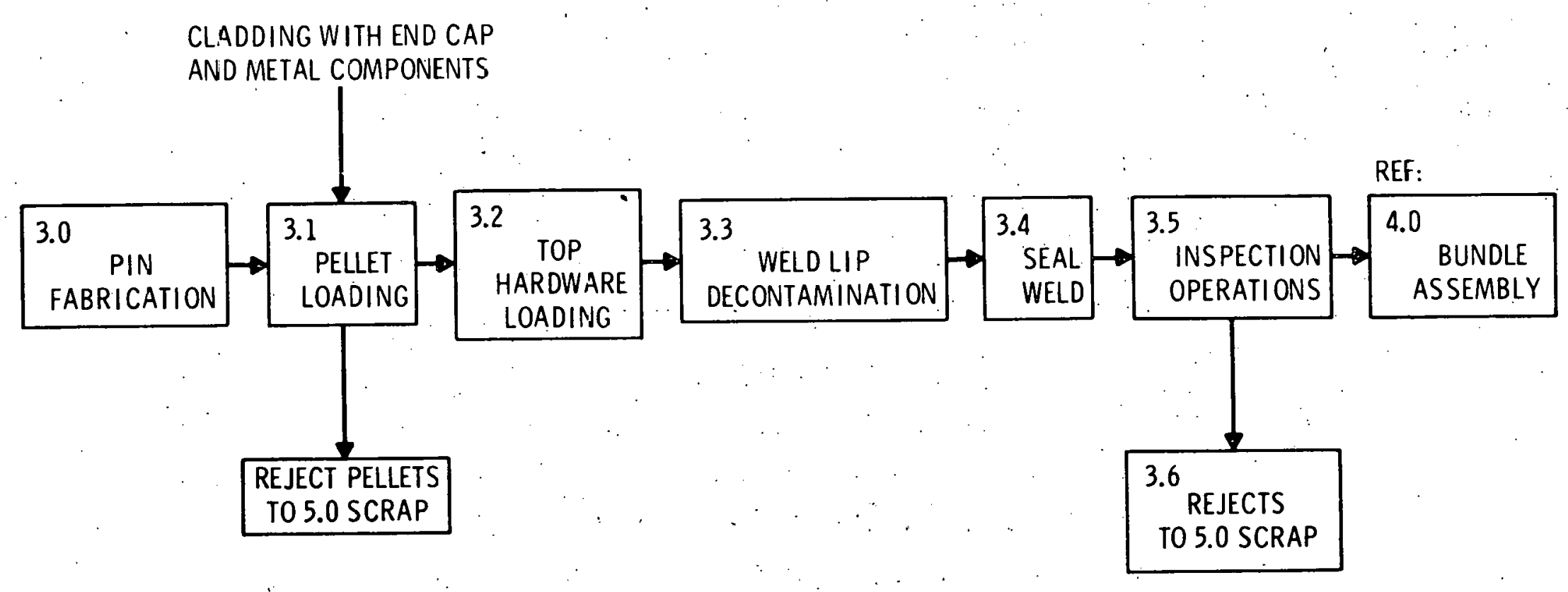


CASE 31

\subsubsection{LMFBR/LWR U/PU COPRDCESSED, CONTAMINATED,} AND RECYCLED CARBIDE FUEL.

FUEL FABRICATION PLANT

LEVEL-2 FUNCTIIONAL FLOW DIACF:AM

4. BUNDLE AS JEMBLY

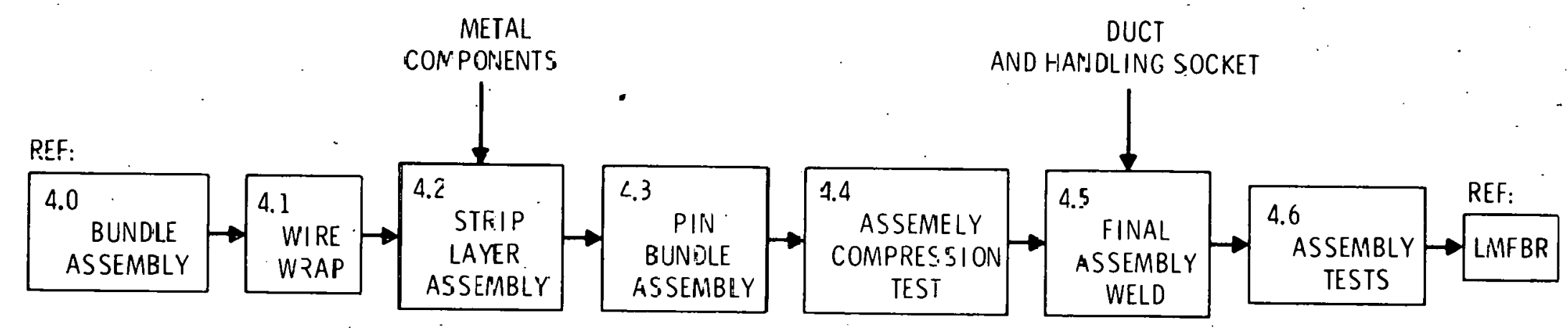




\section{CASE 31 \\ 3.2.3.3 LMFBR/LWR U/Pu COPROCESSED, CONTAMINATED, AND RECYCLED CARBIDE FUEL}

FUEL FABRICATION PLANT

LEVEL-2:FUNCTIONAL FLOW DIAGRAM

5. SCRAP RECYCLE

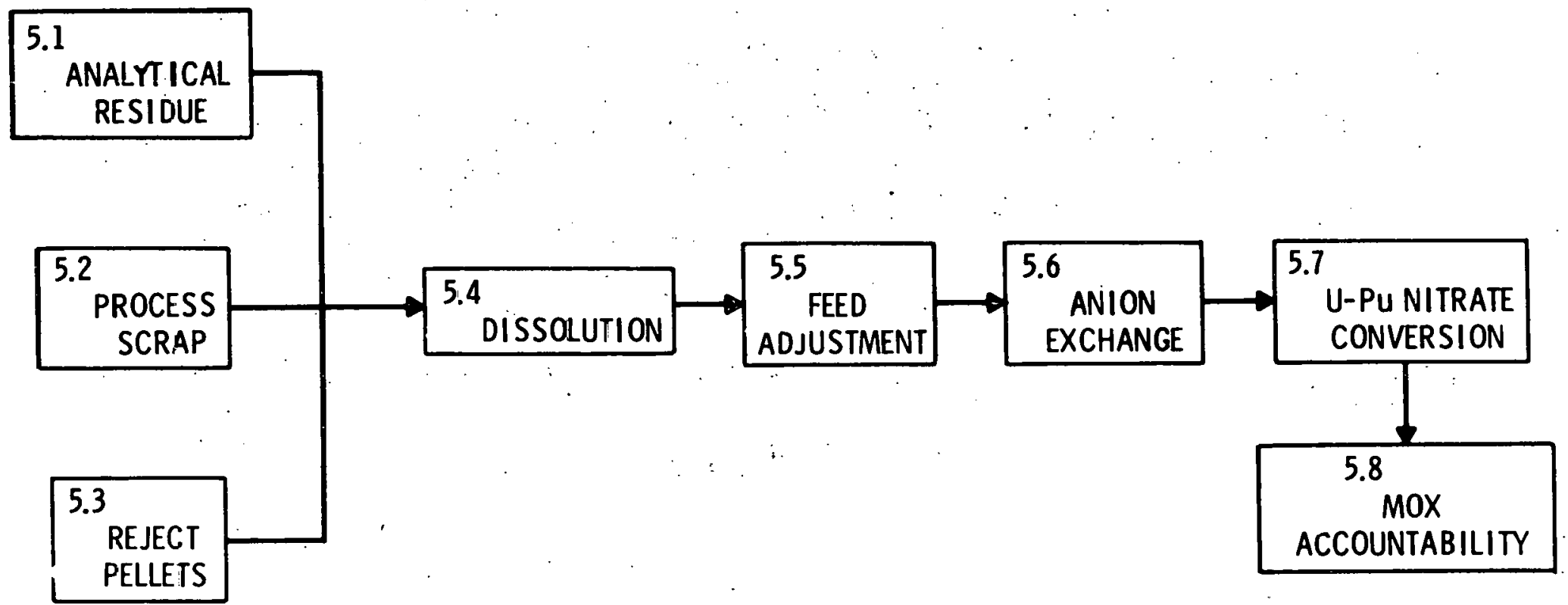

Figure 3.20 


\section{CASE 31 \\ 3.2.3.3 LMFBR/LWR U/Pu COPROCESSED, CONTAMINATED, AND RECYCLED CARBIDE FUEL}

FUEL REFABRICATION

LEVEL-2 FUNCTIONAL FLOW DIAGRAM

6. WASTE REPRIDCESS

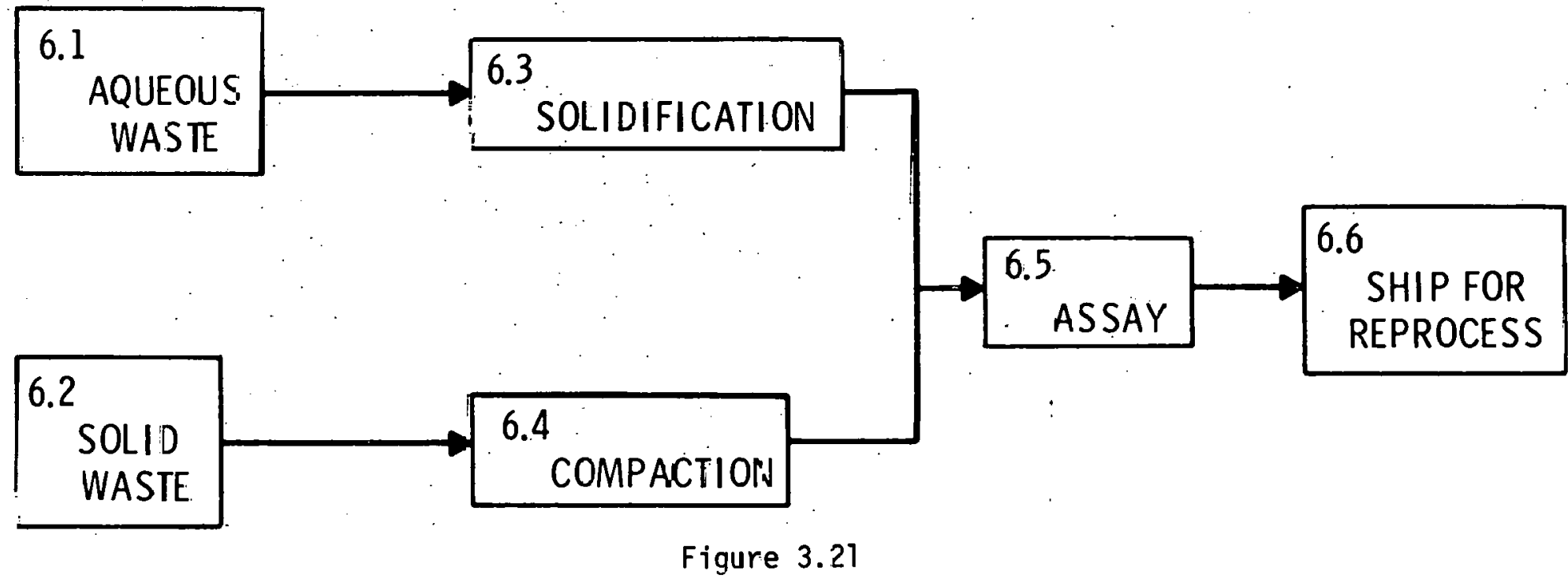




\section{CASE 66 3.4.2.6 ENERGY CENTER CONTAINING LMFBR WITH U-Pu CORE,}

Th BLANKET INSIDE, MODIFIED LEU-Th LMFBR OUTSIDE. EXTERNAL LMFBR SPENT FUEL RETURNED TO CENTER FOR REPROCESSING

LEVEL-0 FUNCTIONAL FLOW DIAGRAM

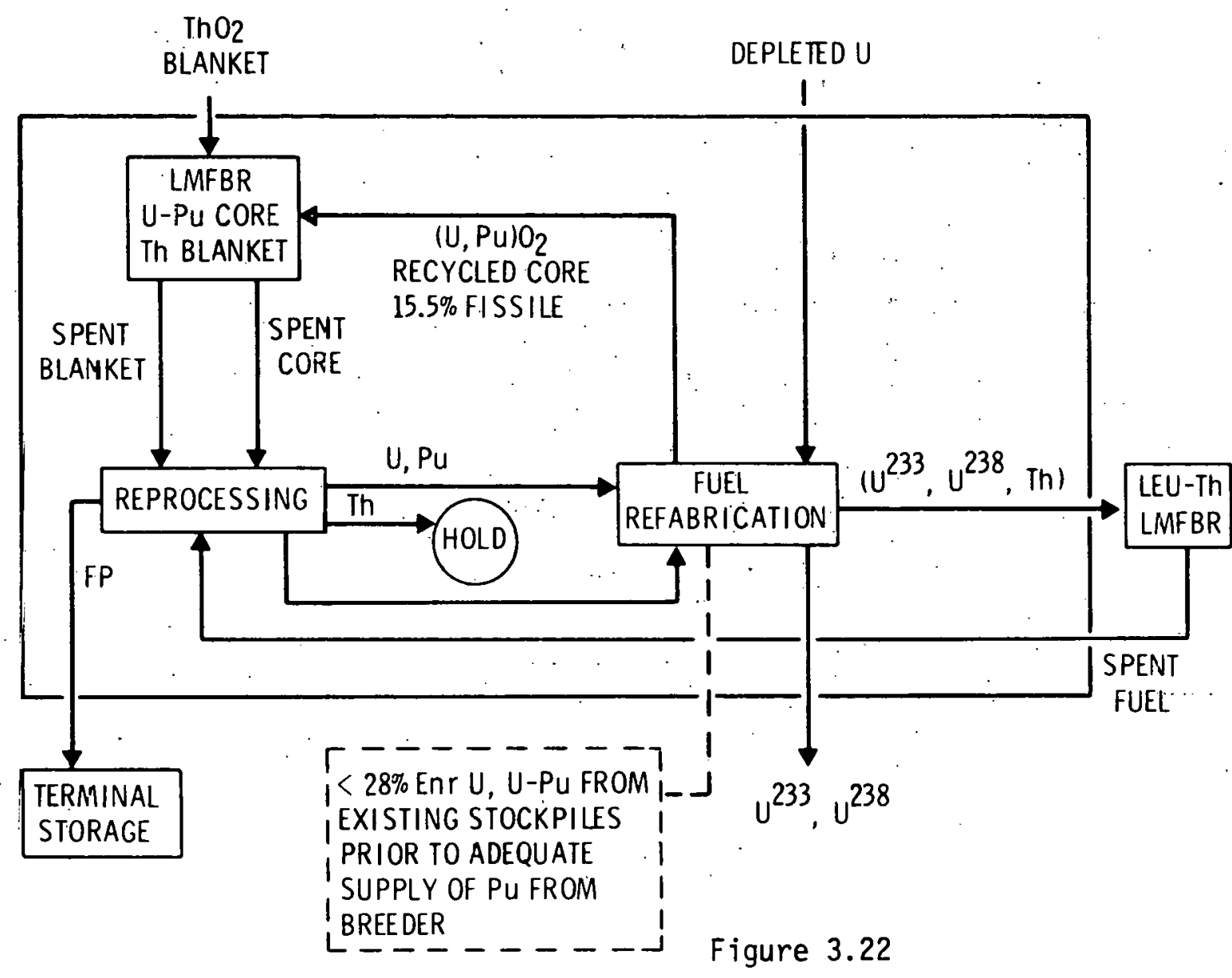




\section{CASE 66}

\subsubsection{ENERGY CENTER CONTAINING LMFBR WITH U-PU CORE,}

Th BLANKET INSIDE, MODIFIED LEU-Th LMFBR OUTSIDE.

\section{EXTERNAL LMFBR SPEMT FUEL RETURNED TO CENTER FOR REPROCESSING}

FUEL REFABRICATION

LEVEL-1 FUNCTIONAL FLOW DIAISRAM

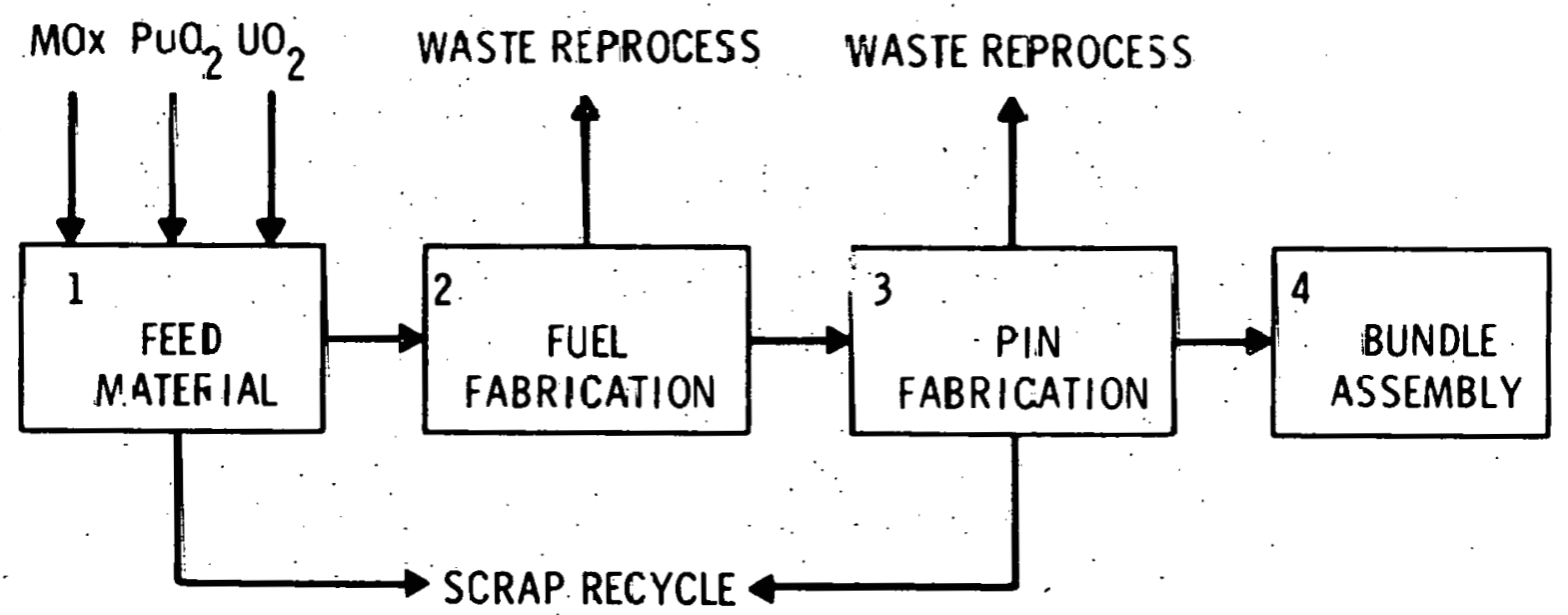

Foure 3.23 


\section{CASE 66 3.4.2.6 ENERGY CENTER CONTAINING LMFBR WITH U-PU CORE,}

Th BLANKET INSIDE, MODIFIED LEU-Th LMFBR OUTSIDE. EXTERNAL LMFBR SPENT FUEL RETURNED TO CENTER FOR REPROCESSING

FUEL REFABRICATION

LEVEL-2. FUNCTIONAL FLOW DIAGRAM

1. FEED MATERIAL

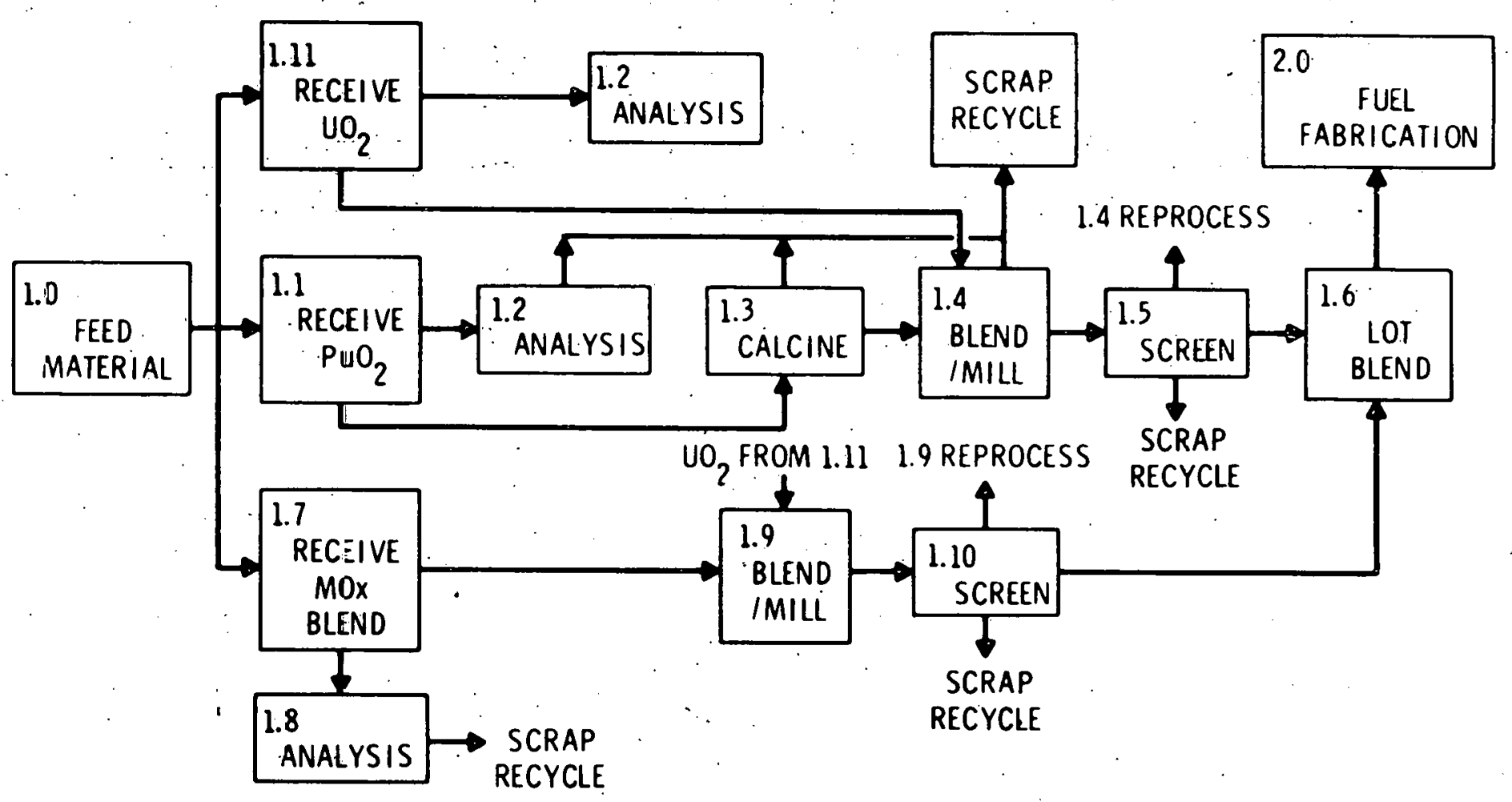




\section{CASE 66 \\ 3.4.2.6 ENERGY CENTER CONTAINING LMFBR WITH U-PU CORE, Th BLANKET INSIDE, MODIFIED LEU-Th LMFBR OUTSIDE. EXTERNAL LMFBR SPENT FUEL RETURNED TO CENTER FOR REPROCESSING}

FUEL REFABRICATION

LEVEL-2 FUNCTIONAL FLOW DIAGRAM

2. FUEL FABRICATION
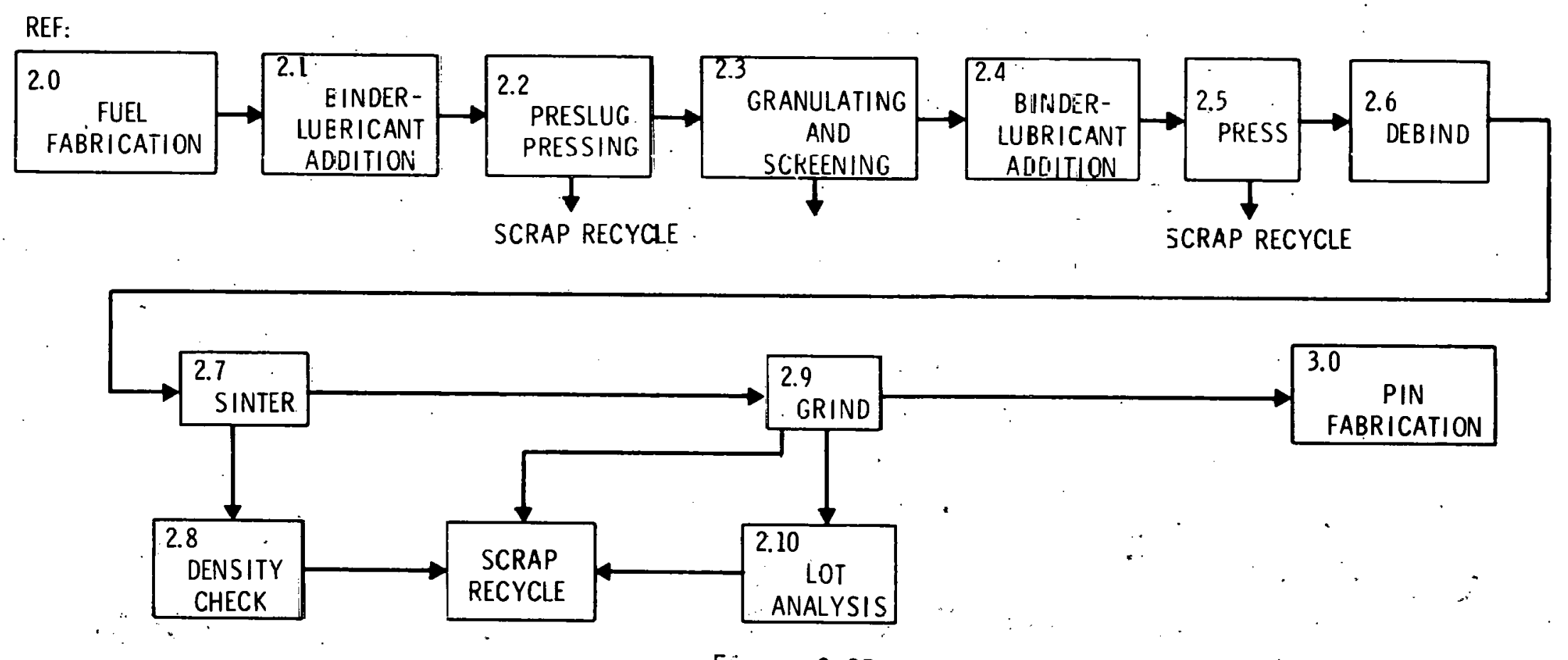

F:gure 3.25 


\section{CASE 66 \\ 3.4.2.6 ENERGY CENTER CONTAINING LMFBR WITH U-Pu CORE, Th BLANKET INSIDE, MODIFIED LEU-Th LMFBR OUTSIDE. EXTERNAL LMFBR SPENT FUEL RETURNED TO CENTER FOR REPROCESSING}

FUEL REFABRICATION

LEVEL-2 FUNCTIONAL FLOW DIAGRAM

3. PIN FABRICATION

CLADDING WITH END CAP

AND METAL COMPONENTS

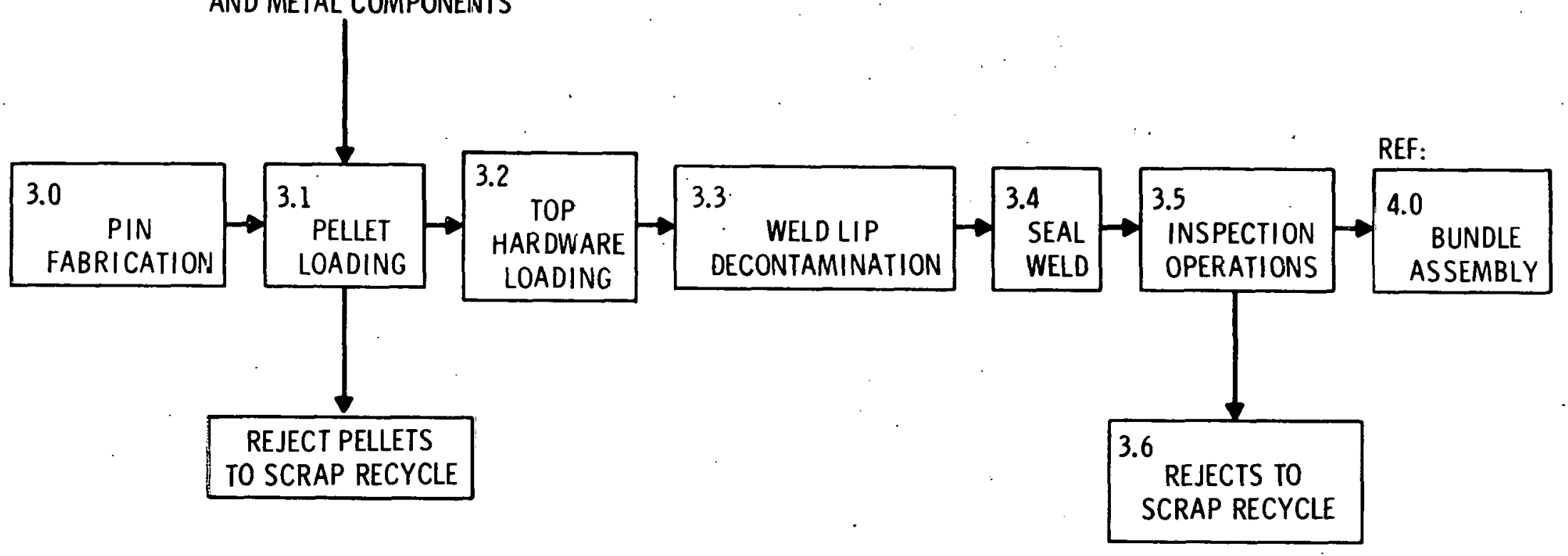

Figure 3.26 


\section{CASE 66}

\subsubsection{ENERGY CENTER CONTAINING LMFBR WITH U-PU CORE,}

Th BLANKET INSIDE, MODIFIED LEU-Th LMFBR OUTSIDE.

\section{EXTERNAL LMFBR SPENT FUEL RETURNED TO CENTER FOR REPROCESSING}

FUEL REFABRICATION

LEVEL 2 FUNCTIONAL FLOW DIAGRAM

4. BUNDLE ASSEMBLY .

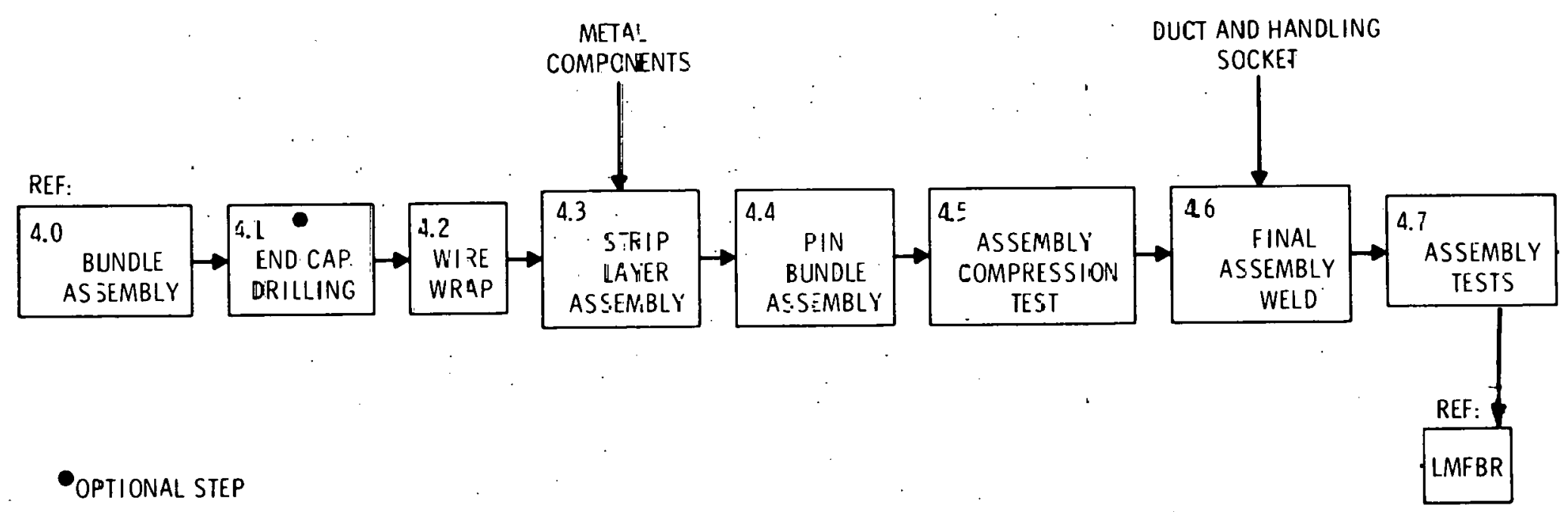

Figure 3.27 
CASE 66 3.4.2.6 ENERGY CENTER CONTAINING LMFBR WITH U-PU CORE, Th BLANKET INSIDE, MODIFIED LEU-Th BRP OUTSIDE. EXTERNAL LMFBR SPENT FUEL RETURNED TO CENTER FOR REPROCESSING

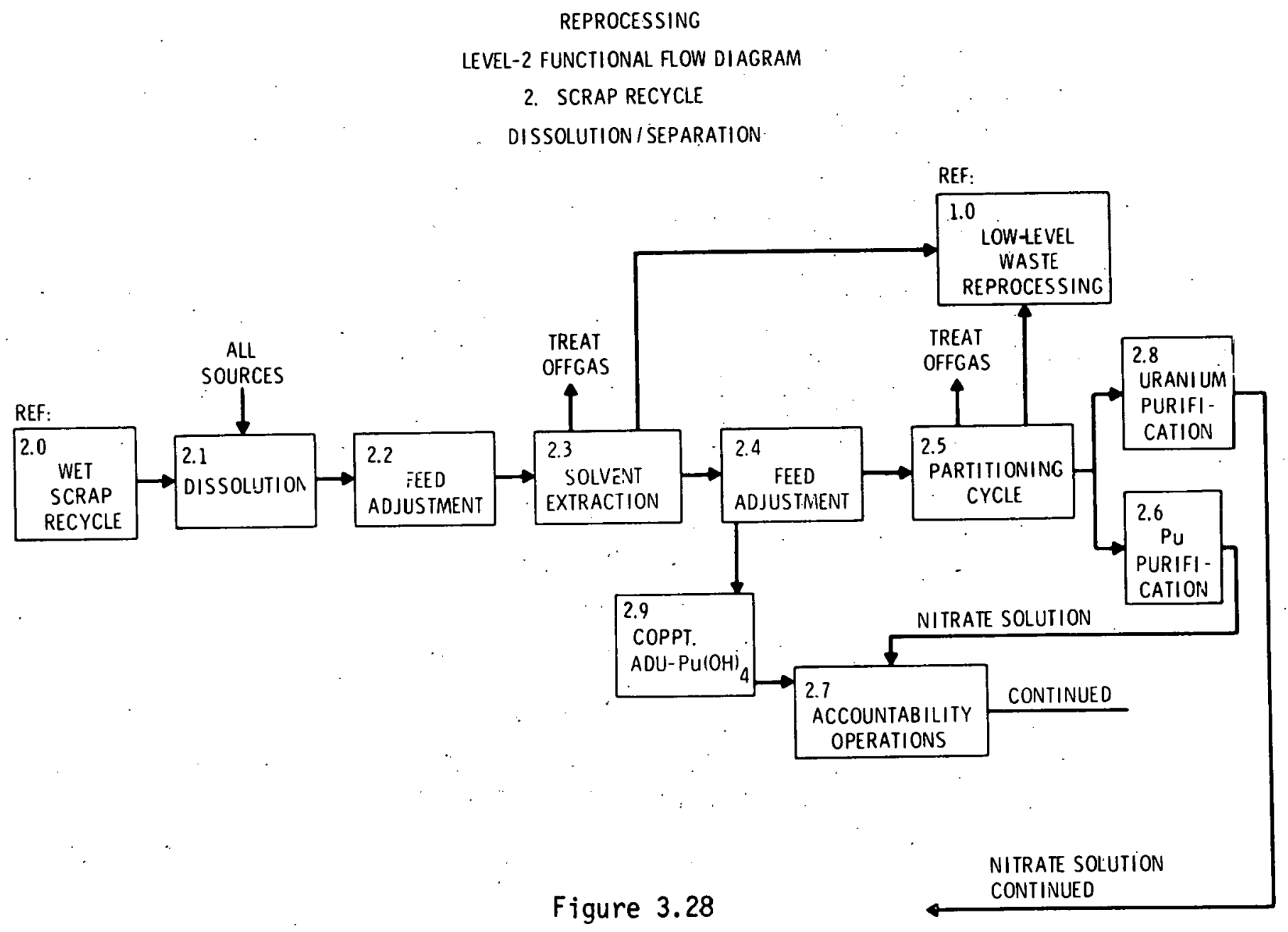




\section{CASE 66 3.4.2.6 ENERGY CENTER CONTAINING LMFBR WITH U-Pu CORE, Th BLANKET INSIDE, MODIFIED LEU-Th LMFBR OUTSIDE. \\ EXTERNAL LMFBR SPENT FUEL RETURNED TO CENTER FOR REPROCESSING}

REPROCESSING

LEVEL-2 FUNCTIONAL FLOW DIAGFAM

2. SCRAP RECYCLE

OXIDE CONVERSION
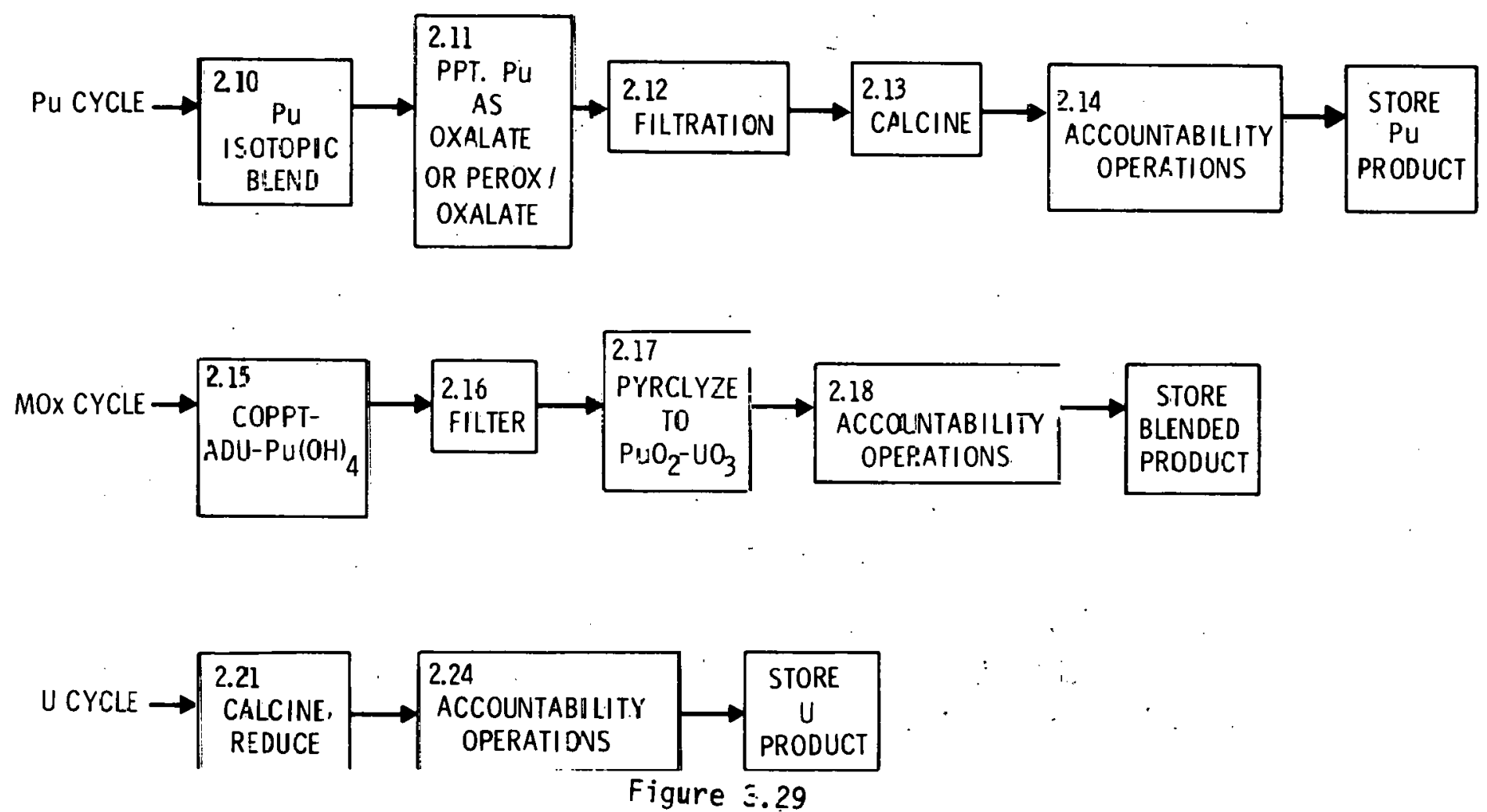


\section{CASE 66}

\subsubsection{ENERGY CENTER CONTAINING LMFBR WITH U-PU CORE, Th BLANKET INSIDE, MODIFIED LEU-Th LMFBR OUTSIDE. EXTERNAL LMFBR SPENT FUEL RETURNED TO CENTER-FOR REPROCESSING}

REPROCESSING

LEVEL-2 FUNCTIONAL FLOW DIAGRAM

3. LOW-LEVEL WASTE

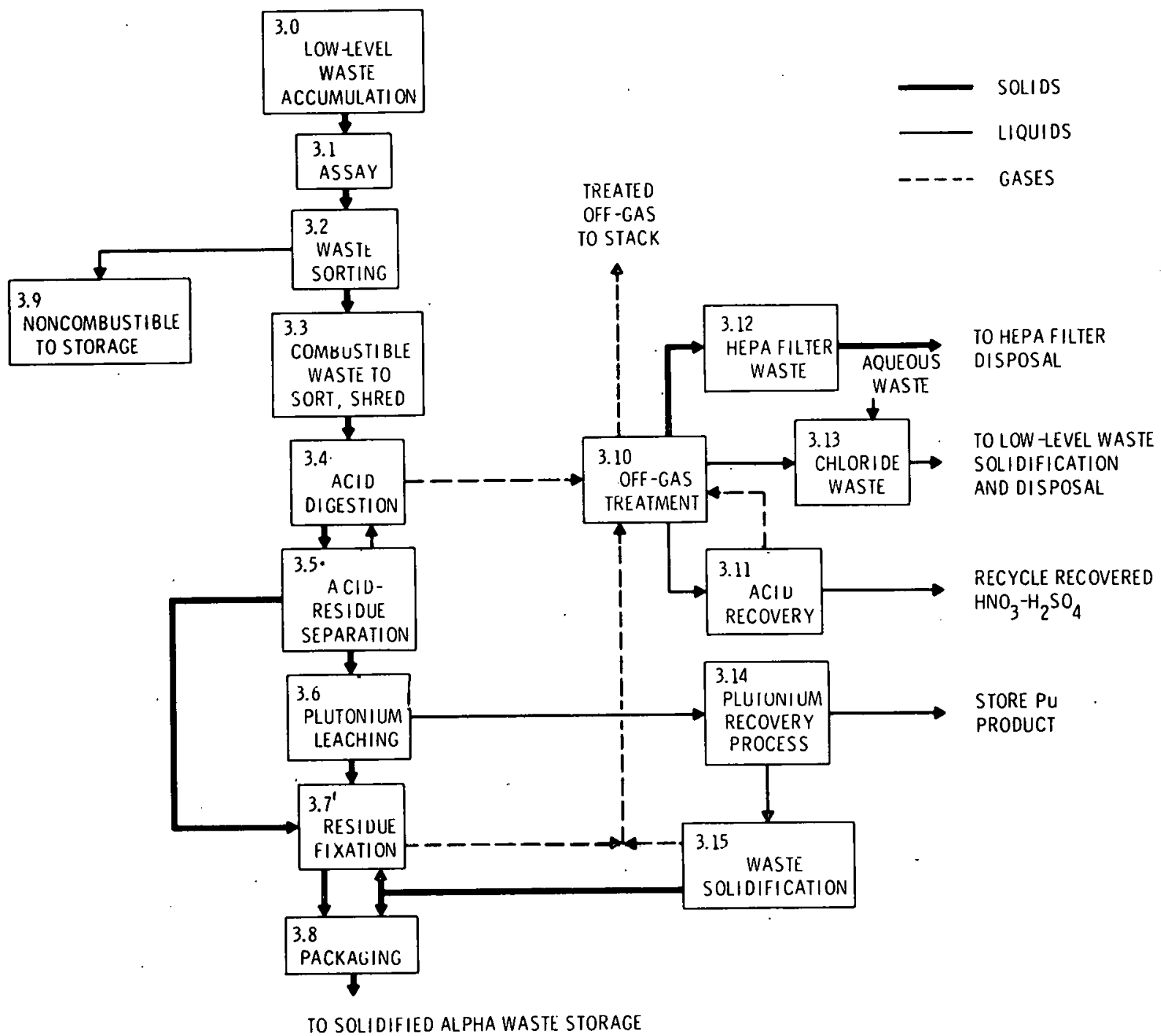

Figure 3.30 
THIS PAGE

\section{WAS INTENTIONALLY LEFT BLANK}


4. FUEL CYCLE EVALUATIONS FOR THORIUM-FUELED REACTORS

AND THE HTGR (Oak Ridge National Laboratory)

R. H. Rainey, W. L. Carter, D. R. Johnson, and J. A. Horak

\subsection{INTRODUCTION}

The analyses of the back cycles for the HTGRs using either the conventional or plutonium-uranium fuel and of the various other nuclear reactor systems with nonconventional (thorium-containing) fuels were made by staff members of the Oak Ridge National Laboratory.

At the time this report was originally prepared, the proliferation risk assessment techniques under development by Science Applications, Inc. $(\mathrm{SAI})^{1}$ and the descriptive matter on the various fuel types proposed in. the EPRI report ${ }^{2}$ were not avallable as a basis for the evaluation. This report therefore represents the authors' understanding of the various reactor systems based on the material distributed at the Atlanta meeting. ${ }^{3}$ An example of the differences between the fuel handling systems evaluated in this report and the fuel handling in ref. 1 is as follows: in this report, except where specified, recycled fuel was assumed to return to the same reactor; that is, if the fuels to the reactor were a driver fuel of ${ }^{235} \mathrm{UO}_{2}-{ }^{238} \mathrm{UO}_{2}$ and a fertile fuel of $\mathrm{ThO}_{2}$ and the ${ }^{233} \mathrm{U}$ was to be recycled to the $\mathrm{UO}_{2}$, then the new driver fuel would contain a mixture of ${ }^{23} \mathrm{U}$, $23{ }^{5} \mathrm{U}$ and ${ }^{238} \mathrm{U}$. In the EPRI report the new charge would contain two separate driver fuels, ${ }^{235} \mathrm{U}$ in ${ }^{238} \mathrm{U}$ and ${ }^{233} \mathrm{U}$ in ${ }^{238} \mathrm{U}$, which may be loaded in different reactors. This difference influences the proliferation evaluation, since credit is taken for the presence of the ${ }^{232} \mathrm{U}$ associated with the ${ }^{23} \mathrm{U}$ to make this fuel less attractive, either for a weapon directly or as a feed to an isotope enrichment plant. For this reason if highly enriched ${ }^{235} \mathrm{U}$ contained ${ }^{233} \mathrm{U}$, it was assumed to be much less attractive for proliferation than if the ${ }^{23}{ }^{3} \mathrm{U}$ were not present.

A report ${ }^{4}$ by H. C. Carney et al., HTGR Fuel Cycle - Definitions for Nonproliferation Assessment, General Atomic Company (Draft), was prepared at approximately the same time as this report. There was not enough time to make the two reports consistent for this publication, but the GA report will be very valuable for the next level of study. 


\section{2 EVALUATION PROCEDURE}

Figures 4.1 through 4.5 present the choice tree diagrams for the back cycle processing schemes of the various reactor systems being evaluated. A brief description is given of each type of reactor fuel recycle scheme and the composition of the fuel that would be the feed to the recovery plant. These descriptions assume that "homogeneous fuels" indicates that the reactor contains only one type fuel, which contains all the designated fissile and fertile materials. "Heterogeneous fuels" indicates that two or more types of fuel are in the reactor and that these are separable before entering the solvent extraction system. When needed, there is an indication that the fuel contains highly enriched uranium (HEU), lowenriched uranium (LEU), or either. The horizontal blocks indicate the reprocessing scheme that would be required for the head-end treatment, reprocessing; and refabrication of the fuel. An attempt was made to include all the choices that could be used to recycle the fuel from each reactor back to the same reactor. The form of the product(s) from each reprocessing and refabrication scheme is included.

The Leve1 1 Functional Flow Diagrams (FFDs) for the dissolution of metal-clad reactor fuel are given in Fig, 4,6. For Zircaloy-clad $\mathrm{UO}_{2}-\mathrm{Pu}_{2}$ fuel or stainless-steel-clad $\mathrm{UO}_{2}-\mathrm{PuO}_{2}$ or $\mathrm{UO}_{2}-\mathrm{ThO}_{2}$ a size reduction followed by a dissolution of the exposed fuel (chop-leach) would be used. For Zircaloy-clad $\mathrm{UO}_{2}-\mathrm{ThO}_{2}$ some as yet undecided method for removing the cladding would be required before the fuel is dissolved. The head-end processes for water-cooled reactors and for liquid-metal-cooled reactors are evaluated in Table 4.1. The FFD for HTGR fuel is given in Fig. 4.7 and evaluated in Table 4.2. For these FFDs, and all that follow, the processing steps being evaluated are enclosed in solid lines. The blocks enclosed by dashes are used to indicate related but not evaluated uperativis.

The FFDs for the various choices for reprocessing the reactor fuels are given in Figs. 4.8 through 4.21 and evaluated in Tables 4.3 through 4.25. These FFDs and tables include the modifications of the Purex and Thorex solvent extraction systems to accommodate the combinations of ${ }^{2}{ }^{5} \mathrm{U},{ }^{2}{ }^{3} \mathrm{U},{ }^{23}{ }^{8} \mathrm{U}, \mathrm{Pu}$, and $\mathrm{Th}$ that have been proposed for use in the reactors and the choices of coextraction and partitioning of these fuels 
in the reprocessing systems. In evaluating the development needed for the various operations, we assumed that mixtures of ${ }^{235} \mathrm{U}$ and ${ }^{238} \mathrm{U}$ would be converted to $\mathrm{UF}_{6}$ for return to an isotope enrichment facility. When ${ }^{2}{ }^{3} \mathrm{U}$ was present, we assumed that it would be enriched by blending with additional ${ }^{23} \mathrm{U}$ or enriched ${ }^{235} \mathrm{U}$. Since the plutonium from recycled power reactor fuels would contain relatively large quantities of ${ }^{238} \mathrm{Pu}$, the conversion and refabrication would require remotely operated equipment. Commercial-scale equipment for these operations has not been developed.

Columns giving Material Location and Materlal Description are included for used in future more refined evaluations of the attractiveness of the material for proliferation. The scales used in rating the effects of the convertibllity of the material and its radiation on the proliferation attractiveness are given in Chap. 1.

Figures 4.8 through 4.14 show various modifications of the Purex solvent extraction process for the reprocessing of fuels containing $235-238 \mathrm{U}$ or ${ }^{233-235-238} \mathrm{U}$ and plutonium. These modifications include the flowsheets for partitioning or coextraction of the uranium and plutonium or systems in which the plutonium remains with the fission products in the aqueous waste. Figures 4.15 through 4.21 give similar modifications for the Thorex process for the reprocessing of either ${ }^{23} \mathrm{U}$ and thorium or mixtures of ${ }^{23} \mathrm{U}$, thorium, and plutonium. There is only limited laboratory-scale data for the three-component system (U-Pu-Th), but the chemistry of the system indicates that processes of the types presented could be successfully operated.

The fuel refabrication flowsheets can a11 be described in terms of two functional flow diagrams. Figure 4.22 is the functional flow diagram for metal-clad sintered pellet fuel. This flow diagram applies to the LWR, HWR, and FBR cases. Figure 4.23 is the functional flow diagram for the fabrication of graphite fuel elements containing coated fuel microspheres. This flow diagram is peculiar to the HTGR. Tables 4.26 through 4.38 provide the preliminary proliferation analysis for the LWR, HWR, and FBR fuel cycles; each of these tables is associated with functional flow diagram 1, Fig. 4.22, Tables 4.39 through 4.46 are associated with functional flow diagram 2, Fig. 4.23, and provide the preliminary proliferation analyses for the HTGR fuel cycles. In addition to the information tabulated in the 
reprocessing analyses, Tables 4.26 through 4.46 also have tabulations of uranium enrichment as LEU, fissile content less than 4\%; MEU, fissile content greater than $4 \%$ and less than $15 \%$ (in the case of ${ }^{235} \mathrm{U}, 20 \%$ ); and HEU, fissile content greater than $15 \%$. The fissile concentration of fuel mixtures is also tabulated as low, less than $4 \%$; medium, between 4 and 15\%; and high, greater than $15 \%$.

For the HTGR cases, colocation of the reprocessing and refabrication plants has been assumed. The product of the HTGR fuel reprocessing plant will be aqueous solutions of uranium, plutonium, and thorium nitrates, which will be pumped directly to the fuel refabrication plant.

In all cases, the refabricated fuel has been assumed to be in the form of metal oxides. The functional flow dlagrams for metal carbide or nitride fuels would be no different at the Level 1 stage. Thus, the distinctions between the oxide fuel and more advanced types would not influence this preliminary analysis.

The analyses of fuel refabrication methods consider the uranium enrichments that are currently used or planned for refabricated fuel: LEU for LWR, HWR, and SSCR, and MEU for FBR and HTGR. The choice tree diagram, Fig. 4.1, considers some advanced HEU fuel as well. The refabrication analyses have not been tabulated for the advanced HEU systems. Nonetheless, the HEU systems can be evaluated by modifying the reference refabrication methods indicated on the choice tree diagram to indicate a compatibility value of $d$ for process steps 1,2 , and 3 . The refabrication methods for which the HEU fuel might be considered are $1,2,3,4,7,8$, 13 , and 14 .

In the evaluation of the effects on proliferation potential due to the difficulty associated with the conversion of the fissionable material to a form suitable for a weapon, it was assumed that low-enriched uranium (LEU) would require isotopic enrichment but that HEU or plutonlum would require only chemical conversion. It was also assumed that the irradiation level of plutonium separated from fission products would not be a major deterrent to its conversion to weapons material. On the other hand, the ${ }^{232} \mathrm{U}$ content of a weapon quantity of ${ }^{23{ }^{3}} \mathrm{U}$, would result in a much higher irradiation field and was considered a deterrent. 


\subsection{CONCLUSION FROM EVALUATION}

The evaluation of the reprocessing processes shows that a major area of proliferation potential is in the "rework and recycle" and the "waste treatment" areas. Even when the main process line is designed to minimize the potential for proliferation there is a relatively good chance that off-specification materials, because of either unintentional or intentional operational errors in the plant, would contain fissionable materials that would be attractive for proliferation. Essentially all process vessels are designed so that solutions can be sent to rework or waste. Due to its isotopic dilution LEU remains unattractive under all conditions. Similarly ${ }^{233} \mathrm{U}$ is always associated with ${ }^{232} \mathrm{U}$ and so is relatively unattractive. On the other hand, plutonium has no "natural" protection and is relatively easy to separate from impurities and so is a more attractive source of material for a weapon. This study shows that this remains true even when the processing plant is designed to leave the plutonium with the fission products.

This study assumed that the ${ }^{23} \mathrm{U}$ was associated with several hundred parts per million of ${ }^{232} \mathrm{U}$. Data that became available ${ }^{5}$ after much of this report was prepared indicate that the ${ }^{23} \mathrm{U}$ may contain as much as $1 \%{ }^{232} \mathrm{U}$. This would indicate that a $10-\mathrm{kg}{ }^{233} \mathrm{U}$ weapon may contain about $100 \mathrm{~g}$ of ${ }^{232} \mathrm{U}$ and have a radiation field of about $10^{4} \mathrm{R}$ at $0.3 \mathrm{~m}(1 \mathrm{ft})$. $\Delta t$ this level the "Radiation Hazard" would rate as "high" rather than "medium," as it was rated in this report. In order for the presence of the ${ }^{232} \mathrm{U}$ to contribute to the irradiation level of the ${ }^{233} \mathrm{U}$, the decay products of the ${ }^{232} \mathrm{U}$ must be present. When the ${ }^{232} \mathrm{U}$ is separated from all of its decay products, the regrowth of activity is limited primarily by the 1.9 -year ha1f-1ife of the ${ }^{228} \mathrm{Th}$. The activity reaches $1 \%$ of its maximum value. in about 15 days. If the uranium is not separated from the thorium in the reproccssing, the regrowth of the decay products is limited by the 3.6-day half-1ife of ${ }^{224} \mathrm{Ra}$. The time available for converting diverted ${ }^{23} \mathrm{U}$ to a weapon material before the decay products of the ${ }^{232} \mathrm{U}$ reach thousands of roentgens at one foot is only a few days when the uranium has been separated from thorium and is too short to be of practical value when the uranium and thorium are not separated. 


\subsection{REFERENCES}

1. G. Borgonnavi et al., A Preliminary Methodology for Evaluating the Proliferation Resistance of Altemative Nuclear Power Systems, SAI-78-596-WA, Science Applications, Inc. (June 15, 1977).

2. N. L. Shapiro and R. A. Matzie, Assessment of Thorium Fuel Cycles in Pressurized Water Reactors, EPRI-NP-359, Combustion Englneering, Inc. (February 1977).

3. Letter from J. A. Lenhard (ORO) to H. Postma (ORNL), Transmittal of Candidate Alternatives Regarding Proliferation Constraints on Various Fuel Cycles, with enclosure, "Nonproliferation Alternative Systems Assessment Program - Preliminary Program Plan," May 18, 1977.

4. H. C. Carney et al., H'l'GK t'uel l'ycle - Definitions for Nonproziferation Assessment, General Atomic Company (Draft).

5. T. H. Pigford and C. S. Yang, "Thorium Fuel Cycles," Draft prepared tor U.S. Environmental Protection Agency under EPA Contract 68-01-1962 with Science Applications, Inc. (June 1977). 
Group 1.2 (WR (Th-U)

Group 3.2 HWR (Th-U)

and 3.4.2 Spectral Shift (In-U)

1.2.1. 3.2.1. and 3.4.2 (full Recycle) HOMOGENEOUS FUEL

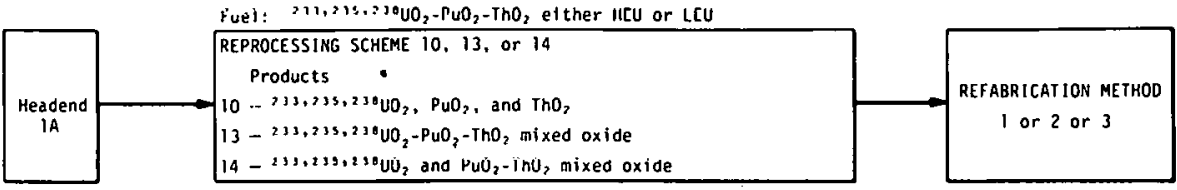

HETEROGENEOUS FUEL

Recycle to same fuel, i.e., Pu to U0:, and '2 'U to $\mathrm{ThO}_{2}$

Fuel 1: $23{ }^{2}{ }^{2}{ }^{\circ} \mathrm{UO}_{2}-\mathrm{PuO}_{2}$. HEU or LEU

Fuel 2: $2 \mathrm{HOO}_{2}-\mathrm{ThO}_{2}$

\begin{tabular}{|l|l|l|} 
Headend \\
IA
\end{tabular}$\left|\begin{array}{l}\text { REPROCESSING SCHEME } 1 \text { and } 8, \text { or I and 9, } \\
\text { or } 3 \text { and } 8, \text { or } 3 \text { and } 9 \\
\text { Products } \\
1-235,23 \mathrm{UF}_{6}, \mathrm{PuO}_{2} \\
3-235,238 \mathrm{UO}_{2}-\mathrm{PuO}_{2}, \mathrm{MOX} \\
8-23 \mathrm{UO}_{2}, \mathrm{ThO}_{2} \\
9-23 \mathrm{UO}_{2}-\mathrm{ThO}_{2} \text { mixed oxide }\end{array}\right| \begin{gathered}\text { REFABRICATION METHOD } \\
4 \text { and } 5 \text { or } \\
4 \text { and } 6 \text { or } \\
7 \text { and } 5 \text { or } \\
7 \text { and } 6\end{gathered}$

Cross progeny, i.e.. recycle " $3 \mathrm{U}$ to $\mathrm{UO}_{\text {; }}$ and $\mathrm{Pu}$ to $\mathrm{ThO}_{2}$

Fuel 1: $23,235,13 \mathrm{UO}_{2}$, $\mathrm{HEU}$ or LEU

Fuel 2: $\mathrm{PuO}_{2}-\mathrm{ThO}_{2}$

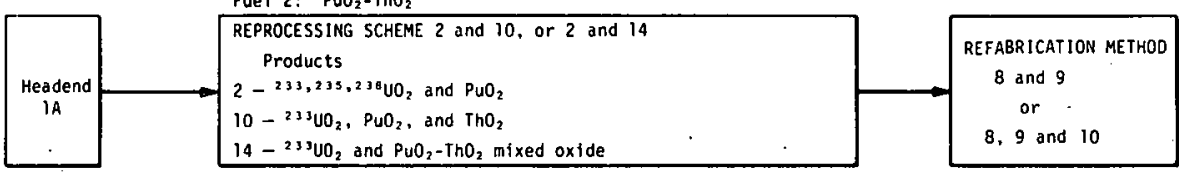

Plutonium recycle one pass only, i.e., plutonium from $\mathrm{UO}_{2}$

recycled to $\mathrm{ThO}_{2}$; plutonium from $\mathrm{ThO}_{2}$ discharged to aqueous phase

with fission products: ${ }^{2}$ " $U$ recycled to either $\mathrm{UO}_{2}$ or $\mathrm{IhO}_{2}$

Fuel 1: 233,235, $23 \mathrm{AOO}_{2}$, HEU Or LEU

Fuel 2: $\mathrm{PuO}_{2}-\mathrm{ThO}_{2}$

Fuel 1: $23 \mathrm{~S}_{2} 2{ }^{\mathrm{Ba}} \mathrm{UO}_{2}$, HEU or LEU

fuel 2: " ${ }^{3} \mathrm{UO}_{2}-\mathrm{PuO}_{2}-\mathrm{ThO}_{2}$

\begin{tabular}{|c|c|c|}
\hline \multirow[b]{2}{*}{$\begin{array}{l}\text { Headend } \\
\text { IA }\end{array}$} & \multirow{2}{*}{$\begin{array}{l}\text { REPROCESSIHG SCHEME } 1 \text { and } 12 \text { or } 2 \text { and } 11 \\
\text { Products } \\
1-235,23 \mathrm{UF}_{6} \text { and } \mathrm{PuO}_{2} \\
2-233,235,23 \mathrm{SO}_{2} \text { and } \mathrm{PuO}_{2} \\
11-2 \mathrm{SO}_{2} \text {, } \mathrm{ThO}_{2} \\
12-23 \mathrm{UO}_{2}-\mathrm{ThO}_{2} \text { mixed oxide }\end{array}$} & REFABRICATION METHOD \\
\hline & & $\begin{array}{c}\text { or } \\
9 \text { and } 8\end{array}$ \\
\hline
\end{tabular}

1.2 .2 and 3.2.2 (Partial recycle, plutonium stowaway) HOMOGENEOUS FUEL

\begin{tabular}{|c|c|c|}
\hline \multirow{2}{*}{ Headend } & $\begin{array}{l}\text { REPROCESSING SCHEME } 11 \text { or } 12 \\
\text { Products }\end{array}$ & REFABRICATION METHOD \\
\hline & $\begin{array}{l}11-233,235,238 \mathrm{UO}_{2}, \mathrm{ThO}_{2} \\
12-233,235,238 \mathrm{UO}_{2}-\mathrm{ThO}_{2} \text { mixed oxide }\end{array}$ & 5 or 6 \\
\hline
\end{tabular}

RETEROGENEOUS FUEL

${ }^{23} \mathrm{U}$ from the $\mathrm{ThO}_{2}$ could be recycled to either the $\mathrm{UO}_{2}$

or the $\mathrm{ThO}_{2}$

Fuel 1: $235,23 \mathrm{UO}_{2}$, HEU or LEU

Fuel 2: ${ }^{2}{ }^{3} \mathrm{JO}_{2}-\mathrm{ThO}_{2}$

Fuel 1: $233,235,23 \mathrm{UOO}_{2}$, HEU Or LEU

Fuel 2: $\mathrm{ThO}_{2}$

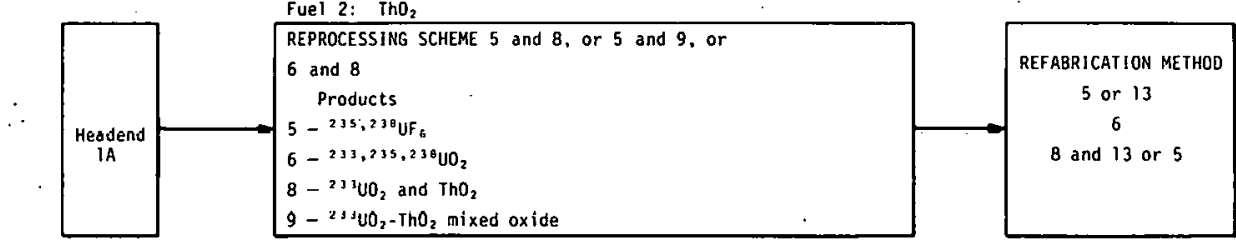

Fig. 4.1. Choice Tree Diagram for Recycle of Th-U Fuels in LWRs, HWRe, and SSCRe. 
2.1.1 Standard Recycle in HTGR

2.1.2 Spiked Recycle in HTGR

2.1.7 Standard Recycle in AGR

Fuel 1: $235,23 \mathrm{OUO}_{2}-\mathrm{PuO}_{2}$, $\mathrm{HEU}$

Fuel 2: ${ }^{235,238 \mathrm{UO}_{2} \text { (natural) }}$

\begin{tabular}{|c|c|c|}
\hline \multirow{2}{*}{$\begin{array}{l}\text { Headend } \\
\quad 2\end{array}$} & $\begin{array}{l}\text { REPROCESSING SCHEME } 1 \text { and } 1 \text {, or } 3 \text { and } 1 \\
\text { Products }\end{array}$ & \multirow{2}{*}{$\begin{array}{c}\text { REFABR ICATION METHOD } \\
14\end{array}$} \\
\hline & $\begin{array}{l}1-235,238 \mathrm{UF}_{6} \text { and } \mathrm{Pu}\left(\mathrm{NO}_{3}\right)_{4} \\
3-235,23 \mathrm{UO}_{2}\left(\mathrm{NO}_{3}\right)_{2}-\mathrm{Pu}\left(\mathrm{NO}_{3}\right)_{4}\end{array}$ & \\
\hline
\end{tabular}

\subsubsection{Coprocessed Recycle in HTGR}

Coprocessing both fuel types would not be a satisfactory procedure. The plutonium concentration in the natural uranium would increase continuously so the design of the fuel would have to change continuously. See above for acceptable choices.

2.1.4 Uranium Recycle with Plutonium Throwaway (stowaway)

Fuel 1: $235,238 \mathrm{UO}_{2}$, HEU

Fuel 2: $235,23{ }^{3} \mathrm{UO}_{2}$ (natural)

\begin{tabular}{|c|c|c|}
\hline \multirow{2}{*}{$\underset{\hat{L}}{\text { Headend }}$} & $\begin{array}{l}\text { REPROCESSING SCHEME } 5 \text { and } 5 \\
\text { Products }\end{array}$ & \multirow{2}{*}{$\begin{array}{l}\text { REFABRICATION METHOD } \\
\text { none requitied }\end{array}$} \\
\hline & $5-235,238 U_{6}$ & \\
\hline
\end{tabular}

2.1.5 Once-through cycle-----oxide fuel

2.1.6 Once-through cycle----metallic fuel

\begin{tabular}{|l|l}
$\begin{array}{l}\text { Headend } \\
\text { none required }\end{array} \longrightarrow \begin{array}{l}\text { REPROCESSING } \\
\text { none required }\end{array}$
\end{tabular}$\longrightarrow \begin{aligned} & \text { REFABRICATION METHOD } \\
& \text { none required }\end{aligned}$

F1g. 4.2, Cholce Tree Dlagram for Recycle of U-Pu Fuels in HTGRs. 
2.2.1 Full Recycle

-Recycle-F-iss i.le-Material.s-to-same-Microsphéres

Fuel 1: $235,23 \mathrm{UOO}_{2}-\mathrm{PuO}_{2}$

Fuel 2: ${ }^{2}{ }^{3} \mathrm{UO}_{2}-\mathrm{ThO}_{2}$

\begin{tabular}{|c|c|c|}
\hline \multirow{3}{*}{$\begin{array}{l}\text { Headend } \\
2\end{array}$} & $\begin{array}{l}\text { REPROCESSING SCHEME } 1 \text { and } 8 \text {, or } 1 \text { and } 9 \text {, } \\
\text { or } 3 \text { and } 8 \text {, or } 3 \text { and } 9 \\
\text { Products }\end{array}$ & \multirow{3}{*}{$\begin{array}{c}\text { REFABR ICATION METHOD } \\
14 \text { and } 15 \\
\text { or } \\
14 \text { and } 16 \\
\text { or } \\
17 \text { and } 15 \\
\text { or } \\
17 \text { and } 16\end{array}$} \\
\hline & $1-{ }^{235,238} \mathrm{UF}_{6}$ and $\mathrm{Pu}\left(\mathrm{NO}_{3}\right)_{6}$ & \\
\hline & $\begin{array}{l}\mathrm{B}-{ }^{2}{ }^{3} \mathrm{UO}_{2}\left(\mathrm{NO}_{3}\right)_{2} \text { and } \mathrm{Th}\left(\mathrm{NO}_{3}\right)_{4} \\
9-2{ }^{3} \mathrm{HO}_{2}\left(\mathrm{NO}_{3}\right)_{2}-\mathrm{Th}(\mathrm{NO})_{3}\end{array}$ & \\
\hline
\end{tabular}

Cross Progeny; Recycle Fissile Materials to Opposite Microspheres

Fuel 1: $233,235,23{ }^{\circ} \mathrm{UO}_{2}$

Fuel 2: $\mathrm{PuO}_{2}-\mathrm{ThO}_{2}$

\begin{tabular}{|c|c|c|}
\hline \multirow[b]{2}{*}{$\begin{array}{l}\text { Headend } \\
2\end{array}$} & $\begin{array}{l}\text { REPROCESSING SCHEME } 2 \text { and } 10 \text {, or } 2 \text { and } 14 \\
\text { Products }\end{array}$ & $\begin{array}{c}\text { REFABRICATION METHOD } \\
18 \text { and } 19\end{array}$ \\
\hline & $\begin{array}{l}.2-233,235,23{ }^{3} \mathrm{UO}_{2}\left(\mathrm{NO}_{3}\right)_{2} \text { and } \mathrm{Pu}\left(\mathrm{NO}_{3}\right)_{4} \\
10-{ }^{23} \mathrm{JO}_{2}\left(\mathrm{NO}_{3}\right)_{2}, \mathrm{Pu}\left(\mathrm{NO}_{3}\right)_{4} \text {, and } \mathrm{Th}\left(\mathrm{NO}_{3}\right)_{4} \\
14-{ }^{23} \mathrm{3OO}_{2}\left(\mathrm{NO}_{3}\right)_{2} \text { and } \mathrm{Pu}\left(\mathrm{NO}_{3}\right)_{4}-\mathrm{Th}\left(\mathrm{NO}_{3}\right)_{4}\end{array}$ & $\begin{array}{c}\text { or } \\
20 \text { and } 19\end{array}$ \\
\hline
\end{tabular}

2.2.2 Partial Recycle (Plutonium to Aqueous with Fission Products)

Recycle ${ }^{23} \mathrm{U}$ to the $\mathrm{UO}_{2}$ fuel

Fuel 1: $233,235,23 \mathrm{UO}_{2}$

Fuel 2: $\mathrm{ThO}_{2}$

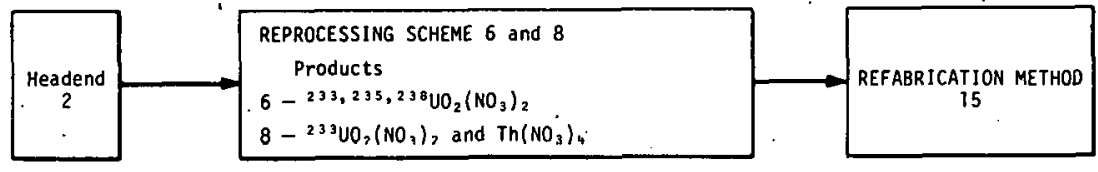

Recycle ${ }^{23} \mathrm{U}$ to the $\mathrm{ThO}_{2}$ Fuel

Fuel 1: $235,23 \mathrm{BOO}_{2}$ HEU or LEU

Fuel 2: ${ }^{23}{ }^{3} \mathrm{UO}_{2}-\mathrm{ThO}_{2}$

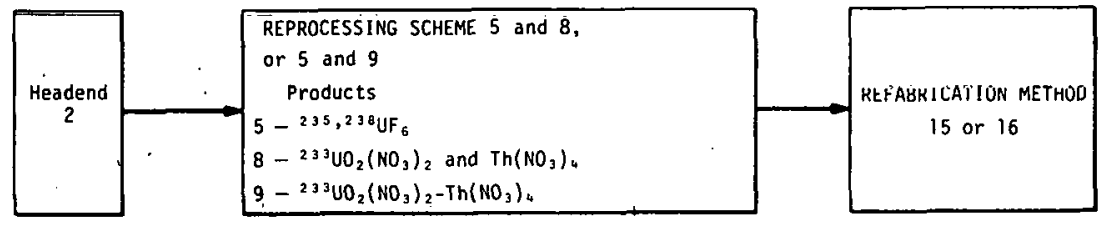

2.2.3 HEU -Th(Cambide) HTGR Full Recycle (Reforonco)

2.2.4 HEU-Th in Pebble-Bed Gas Reactor with Full Recycle (Reference)

Fuel 1: $233,235,238 \mathrm{UO}_{2}$

Fuel 2: ' $\mathrm{ThO}_{2}$

\begin{tabular}{|c|c|c|}
\hline \multirow{2}{*}{$\begin{array}{l}\text { Headend } \\
2\end{array}$} & $\begin{array}{l}\text { REPROCESSING SCHEME } 6 \text { and } 8 \\
\text { Products }\end{array}$ & \multirow{2}{*}{$\begin{array}{l}\text { REFABR ICATION METHOD } \\
15 \text { OR } 21\end{array}$} \\
\hline & $\begin{array}{l}6-233,235,23 \mathrm{UO}_{2}\left(\mathrm{NO}_{3}\right)_{2} \\
8-{ }^{23}{ }^{3} \mathrm{UO}_{2}\left(\mathrm{NO}_{3}\right)_{2} \text { and } \mathrm{Th}\left(\mathrm{NO}_{3}\right)_{4}\end{array}$ & \\
\hline
\end{tabular}

F1g, 4.3. Cholce Tree Dlagram for Recycle of Th-U Fuels in HTGRs. 
GROUP 4.2 LMFBR (Th-U Cycle)

4.2.1 U-Pu-Th Full Recycle LMFBR/LWR

Fuel to LWR ( ${ }^{23} \mathrm{U} U$ from LMFBR)

Fuel 1: 233,235,238 $\mathrm{UO}_{2}$, LEU

\begin{tabular}{c|c|c|}
$\begin{array}{c}\text { Headend } \\
\text { la }\end{array}$ & $\begin{array}{l}\text { REPROCESSING SCHEME 2 } \\
\text { Products } \\
2-233,235,23 \mathrm{UO}_{2} \text { and } \mathrm{PuO}_{2}\end{array}$
\end{tabular}

Fuel to LMFBR (Pu from LWR)

Fuel 1: 235, 23A $\mathrm{HO}_{2}-\mathrm{PuO}_{2}$ LEU Or HEU

Fuel 2: $\mathrm{ThO}_{2}$

\begin{tabular}{|c|c|c|}
\hline \multirow[b]{2}{*}{$\begin{array}{l}\text { Headend } \\
\text { ib }\end{array}$} & $\begin{array}{l}\text { RÉPROCESSSING SCHEME } 1 \text { and } 8 \\
\text { Products }\end{array}$ & REFABRICATION METHOD \\
\hline & $\begin{array}{l}1-235,29 \mathrm{UF}_{6} \text { and } \mathrm{PuO}_{2} \\
8-23 \mathrm{UO}_{2} \text { and } \mathrm{ThO}_{2}\end{array}$ & 4 \\
\hline
\end{tabular}

4.2.2 U-233/U-238/Th LMF8R/LWR, U recycle, Pu throwaway

Fuel to LWR ( 2 a a $U$ from LMFBR)

Fuel 1: $233,235,23{ }^{3} \mathrm{UO}_{2}$, LEU

\begin{tabular}{|c|c|c|}
\hline \multirow{2}{*}{$\begin{array}{l}\text { Headend } \\
\text { la }\end{array}$} & $\begin{array}{l}\text { REPROCESSING SCHEME } 6 \\
\text { Products }\end{array}$ & REFABRICATION METHOD \\
\hline & $6-233,235,23{ }^{1} \| n_{\lambda}$ (Pul with FPs) & 8 \\
\hline
\end{tabular}

Fuel to LMFBR

ruel 1! LOS $2 \mathrm{SOUU}_{2}$, HLU

Fuel 2: $\mathrm{ThO}_{2}$

\begin{tabular}{|c|c|c|}
\hline \multirow{2}{*}{$\begin{array}{l}\text { Heádénd } \\
\text { lh }\end{array}$} & $\begin{array}{l}\text { REPROCESSING SCHEME } 5 \text { and } 8 \\
\text { Products }\end{array}$ & \multirow{2}{*}{$\begin{array}{c}\text { REFAËRICÁI IÚN ME I HUU } \\
13\end{array}$} \\
\hline & $\begin{array}{l}5=235,233_{11 F_{0}}\left(P_{4} \text { with } F_{G G}\right) \\
8-23 \mathrm{UO}_{2} \text { and } \mathrm{ThO}_{2}\end{array}$ & \\
\hline
\end{tabular}

4.2̇.3 U-233/Th LMFBR/LWR full recycle

Fuel to $L W \bar{R}\left({ }^{2}{ }^{39} \mathrm{U}\right.$ from $L M F B R$ )

Fuel 1: 233,235,238 UQ?, LEU

\begin{tabular}{|c|c|c|}
\hline \multirow{2}{*}{$\begin{array}{l}\text { Headent } \\
\text { la }\end{array}$} & $\begin{array}{l}\text { REPROCESSING SCHEME } 2 \\
\text { rroduCTS }\end{array}$ & \multirow{2}{*}{$\begin{array}{c}\text { RFPABR TCATION METFÜD } \\
8\end{array}$} \\
\hline & $2-233,235,23 \mathrm{uOO}_{2}$ & \\
\hline
\end{tabular}

Fuel to LMFBR

Fuel 1: ${ }^{2}{ }^{3} \mathrm{UO}_{2}-\mathrm{ThO}_{2}$, LEU

Fuel 2: $\mathrm{ThO}_{2}$

\begin{tabular}{|c|c|c|}
\hline \multirow{2}{*}{$\begin{array}{l}\text { Headend } \\
\text { ib }\end{array}$} & \multirow{2}{*}{$\begin{array}{l}\text { REPROCESSING SCHEME } 8 \text { (combine fuels) } \\
\text { Producte } \\
8-{ }^{23} \mathrm{JO}_{2} \text { and } \mathrm{ThO}_{2}\end{array}$} & REFABRICATION MFTHON \\
\hline & & 5 \\
\hline
\end{tabular}

Fig. 4.4. Choice Tree Diagram for Recycle of Th-U Fuels in LMFBRs. 
GROUP 5.2 GCFR (Th-U Cycle)

5.2.1 U-Pu-Th Full Recycle GCFR/LWR

Fuel to LWR ( $23 \mathrm{~J}$ from GCFR)

Fuel 1: $233,235,23 \mathrm{UO}_{2}, \mathrm{LEU}$

\begin{tabular}{|c|c|c|}
\hline $\begin{array}{c}\text { Headend } \\
\text { IA }\end{array}$ & $\begin{array}{l}\text { REPROCESSING SCHEME 2 } \\
\text { Produets } \\
233,235,23 \mathrm{BuO}_{2} \text { and } \mathrm{PuO}_{2}\end{array}$
\end{tabular}

Fuel to GCFR (PU from LWR)

Fuel 1: $235,23 \mathrm{UO}_{2}-\mathrm{PuO}_{2}$, LEU Or HEU

Fuel 2: $\mathrm{ThO}_{2}$

\begin{tabular}{|c|c|c|}
\hline \multirow[t]{2}{*}{$\begin{array}{l}\text { Headend } \\
\text { IA }\end{array}$} & \multirow{2}{*}{$\begin{array}{l}\text { REPROCESSING SCHEME } 1 \text { and } 8 \\
\text { Products } \\
1-{ }^{235,238} \mathrm{UF}_{6} \text { and } \mathrm{PuO}_{2} \\
8-{ }^{23}{ }^{3} \mathrm{UO}_{2} \text { and } \mathrm{ThO}_{2}\end{array}$} & REFABRICATION METHOD \\
\hline & & 4 \\
\hline
\end{tabular}

5.2.2 U-233/U-238/Th GCFR/LWR, U recycle, Pu stowaway

Fuel to LWR ( ${ }^{233} \mathrm{U}$ from GCFR)

Fuel 1: $233,235,23 \mathrm{UOO}_{2}$, LEU

\begin{tabular}{c|c|c|}
\hline $\begin{array}{l}\text { Headend } \\
\text { IA }\end{array}$ & $\begin{array}{l}\text { REPROCESSING SCHEME } 6 \\
\text { Products } \\
6-233,235,238 \mathrm{UO}_{2} \text { (Pu with FPS) }\end{array}$
\end{tabular}

Fuel to GCFR

Fuel 1: $235,238 \mathrm{VO}_{2}$, HEU

Fuel 2: $\mathrm{ThO}_{2}$

\begin{tabular}{|c|c|c|}
\hline \multirow[t]{2}{*}{$\begin{array}{l}\text { Headend } \\
\text { IA }\end{array}$} & $\begin{array}{l}\text { REPROCESSING SCHEME } 5 \text { and } 8 \\
\text { Products }\end{array}$ & REFABRICATION METHOD \\
\hline & $\begin{array}{l}5-235,23{ }^{3} \mathrm{UF}_{6} \text { (Pu with FPs) } \\
8-{ }^{233} \mathrm{PO}_{2} \text { and } \mathrm{ThO}_{\mathrm{z}}\end{array}$ & 13 \\
\hline
\end{tabular}

3.2.3 U-233/Ih tiltk/LWK, tüll recycie

Fuel to LWR $\left({ }^{23} \mathrm{U}\right.$ from GCFR)

Fuel 1: $233,235,23{ }^{3} \mathrm{UO}_{2}$, LEU

\begin{tabular}{|l|l|}
$\begin{array}{c}\text { Headend } \\
\text { IA }\end{array}$ & $\begin{array}{l}\text { REPROCESSING SCHEME 2 } \\
\text { Products } \\
2-23,215,2,8 \mathrm{UO}_{2}\end{array}$
\end{tabular}

Fuel to GCFR

Fuel 1: ${ }^{2}{ }^{3} \mathrm{HO}_{2}-\mathrm{ThO}_{2}$, LEU

Fuel 2: $\mathrm{ThO}_{2}$

\begin{tabular}{|c|c|c|c|}
\hline \multirow[t]{2}{*}{$\begin{array}{l}\text { Headend } \\
\text { IA }\end{array}$} & & $\begin{array}{l}\text { REPROCESSING SCHEME } 8 \text { (combine fuels) } \\
\text { Products }\end{array}$ & . REFABRICATION METHOD \\
\hline & - & $8-23{ }^{3} \mathrm{UO}_{2}$ and $\mathrm{ThO}_{2}$ & 5 \\
\hline
\end{tabular}

FIg. 4.5. Cholce Tree Dlagram for Recycle of Th-U Fuels in GCFRs. 


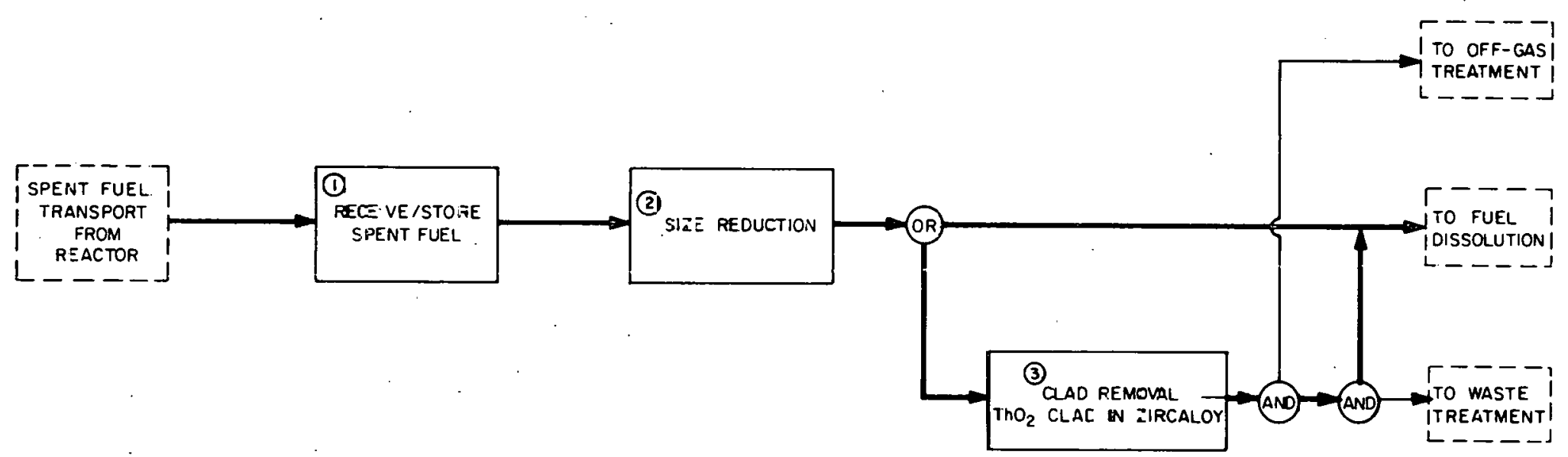

Fig. 4.6. Head-Erd Scheme 1 - Leve1 1 Functional Flow Iliagram: Head-End Treatment of LWR, HWR, and FBR Fuels. 
Table 4.1.: Head-End Processing. Scheme 1

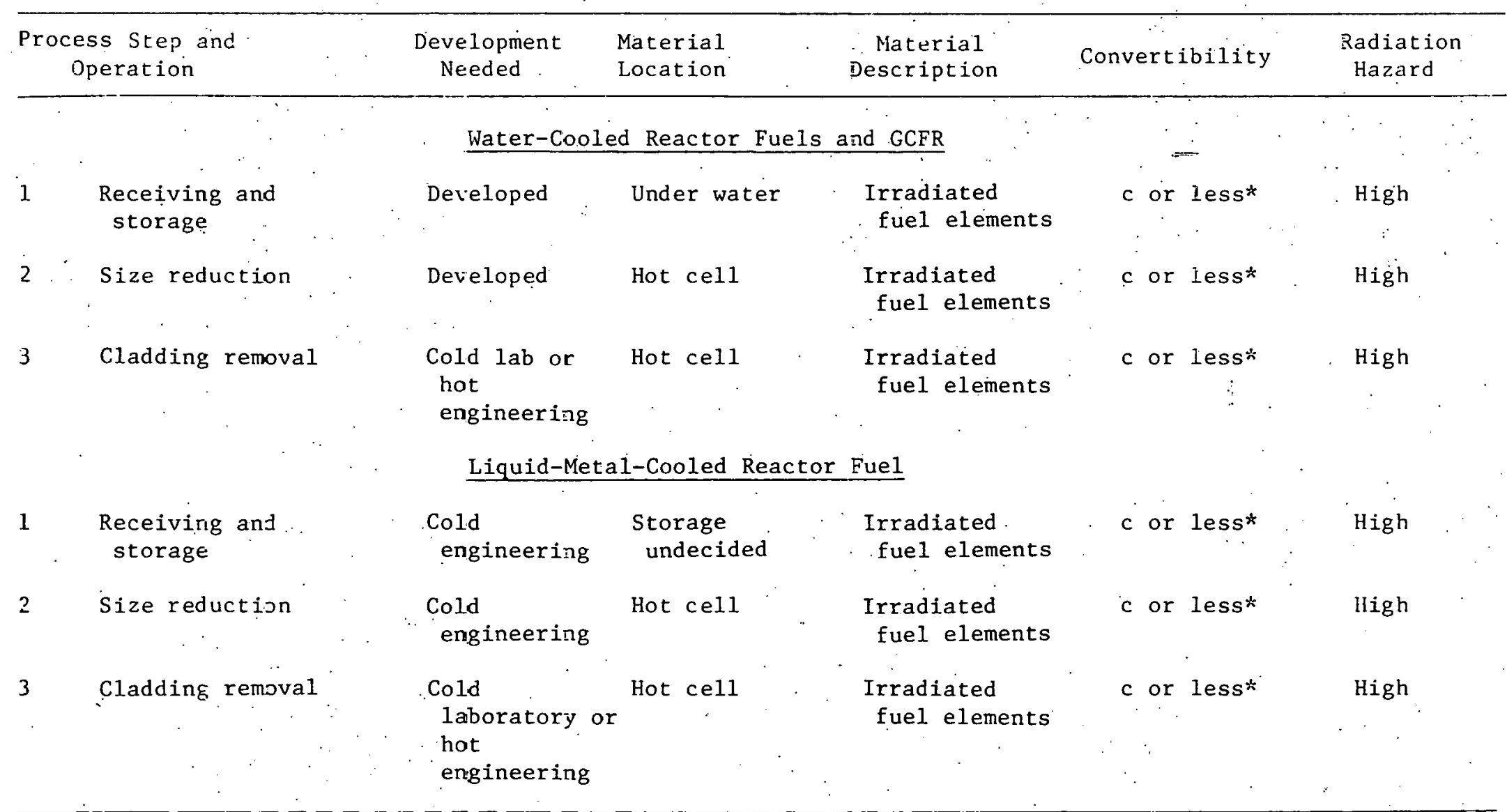

*Could also require isotope separation, which would lower the rating of the convertibility. 


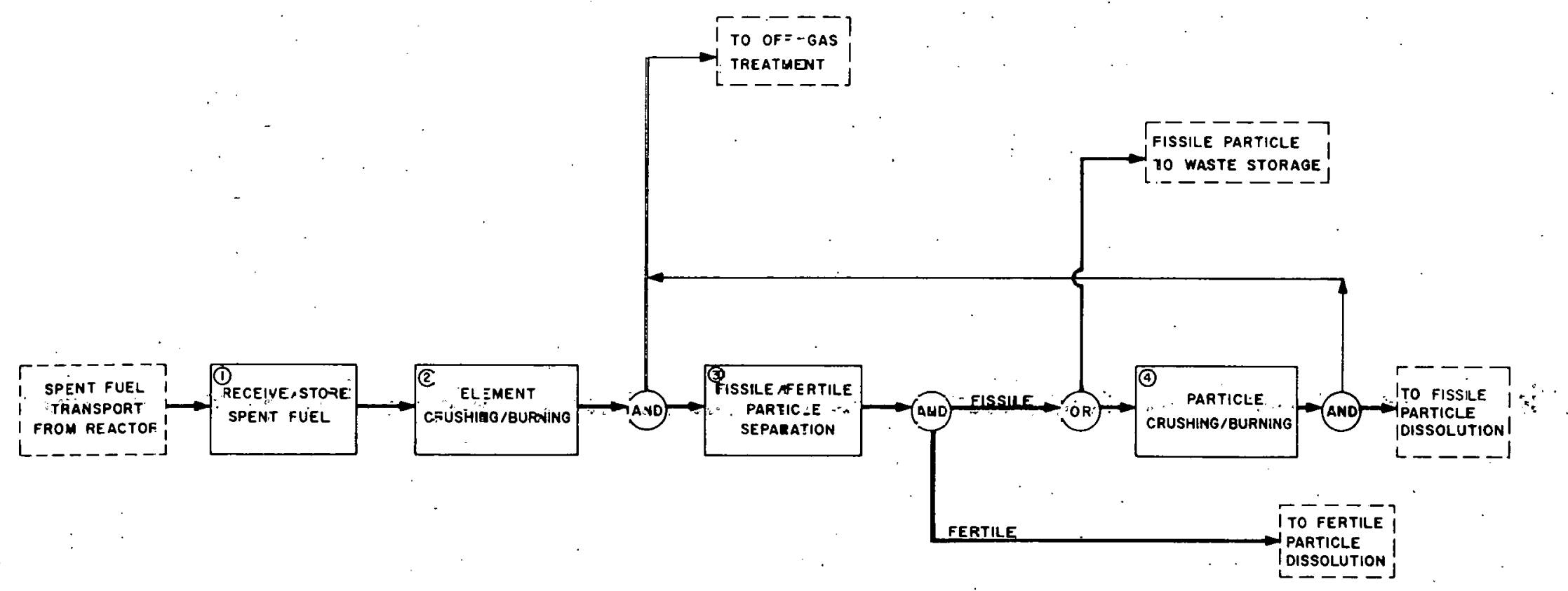

Fig. 4.7. Head-Erd Schere 2-Leve1 1 Functional Flow Diagram: Hecd-End Treatment of HTGR Fuel. 
Table 4.2. Head-End Reprocessing Scheme 2 for HTGR

\begin{tabular}{|c|c|c|c|c|c|c|}
\hline \multicolumn{2}{|c|}{$\begin{array}{c}\text { Process Ster and } \\
\text { Operation }\end{array}$} & \multirow{2}{*}{$\begin{array}{l}\begin{array}{l}\text { Development } \\
\text { Needed }\end{array} \\
\begin{array}{l}\text { Cold } \\
\text { engineering }\end{array}\end{array}$} & \multirow{2}{*}{$\frac{\begin{array}{l}\text { Material } \\
\text { Location }\end{array}}{\text { Vault storage }}$} & \multirow{2}{*}{$\begin{array}{c}\text { Material } \\
\text { Description }\end{array}$} & \multirow{2}{*}{$\frac{\text { Convertibility }}{\text { c or less* }}$} & \multirow{2}{*}{$\frac{\begin{array}{c}\text { Radiation } \\
\text { Hazard }\end{array}}{\text { High }}$} \\
\hline 1 & $\begin{array}{l}\text { Receiving and } \\
\text { storage }\end{array}$ & & & & & \\
\hline 2 & $\begin{array}{l}\text { Fuel element } \\
\text { crush and burn }\end{array}$ & $\begin{array}{l}\text { Cold } \\
\text { engineering }\end{array}$ & Hot cell & $\begin{array}{l}\text { Irradiated } \\
\text { microspheres }\end{array}$ & c or less* & High \\
\hline 3 & $\begin{array}{l}\text { Fissile-fertile } \\
\text { separation }\end{array}$ & $\begin{array}{l}\text { Cold } \\
\text { engineering }\end{array}$ & Hot cell & $\begin{array}{l}\text { Irradiated } \\
\text { microspheres }\end{array}$ & $c$ or less* & High \\
\hline 4 & $\begin{array}{l}\text { Particle crish } \\
\text { and burn }\end{array}$ & $\begin{array}{l}\text { Ccld } \\
\text { engineering }\end{array}$ & Hot cell & $\begin{array}{l}\text { Irradiated } \\
\text { fuel kernels }\end{array}$ & c or less* & High \\
\hline
\end{tabular}

*Could also require isotope separation, which would lower the rating of the convertibility: 
ORNL DWG $77: 1414$

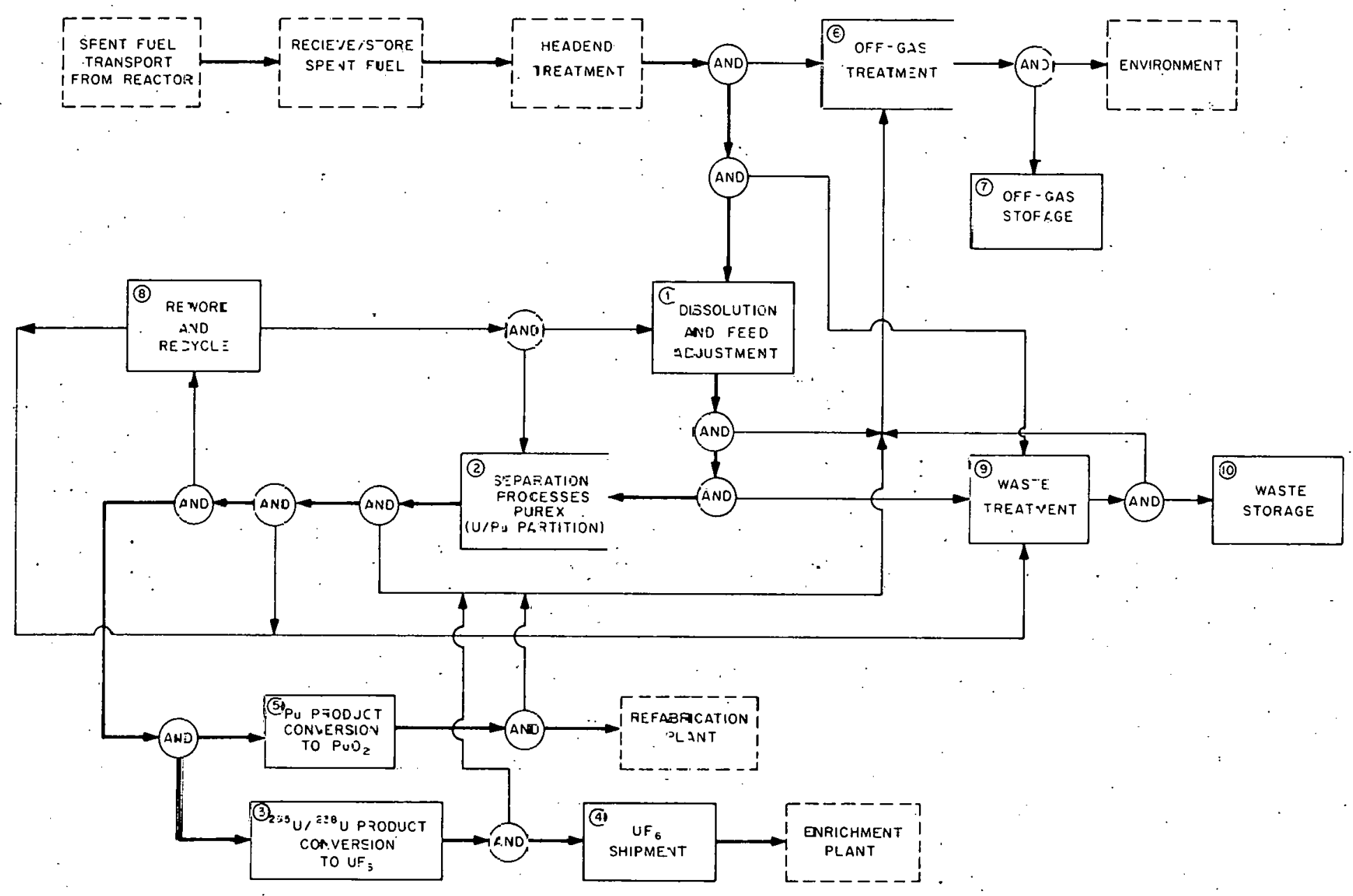

Fig. 4.8. Reprocessing Scheme 1-Level 1 Functional Flow Diagram: Reprocessing $\left({ }^{235} \mathrm{U},{ }^{238} \mathrm{U}\right) \mathrm{O}_{2}-\mathrm{PuC}_{2}$ Fuel by the Purex Process. Partition of uranium and plutonium. 
Table 4.3. Analysis for Reprocessing Scheme 1 for $<20 \%{ }^{235} \mathrm{U}$

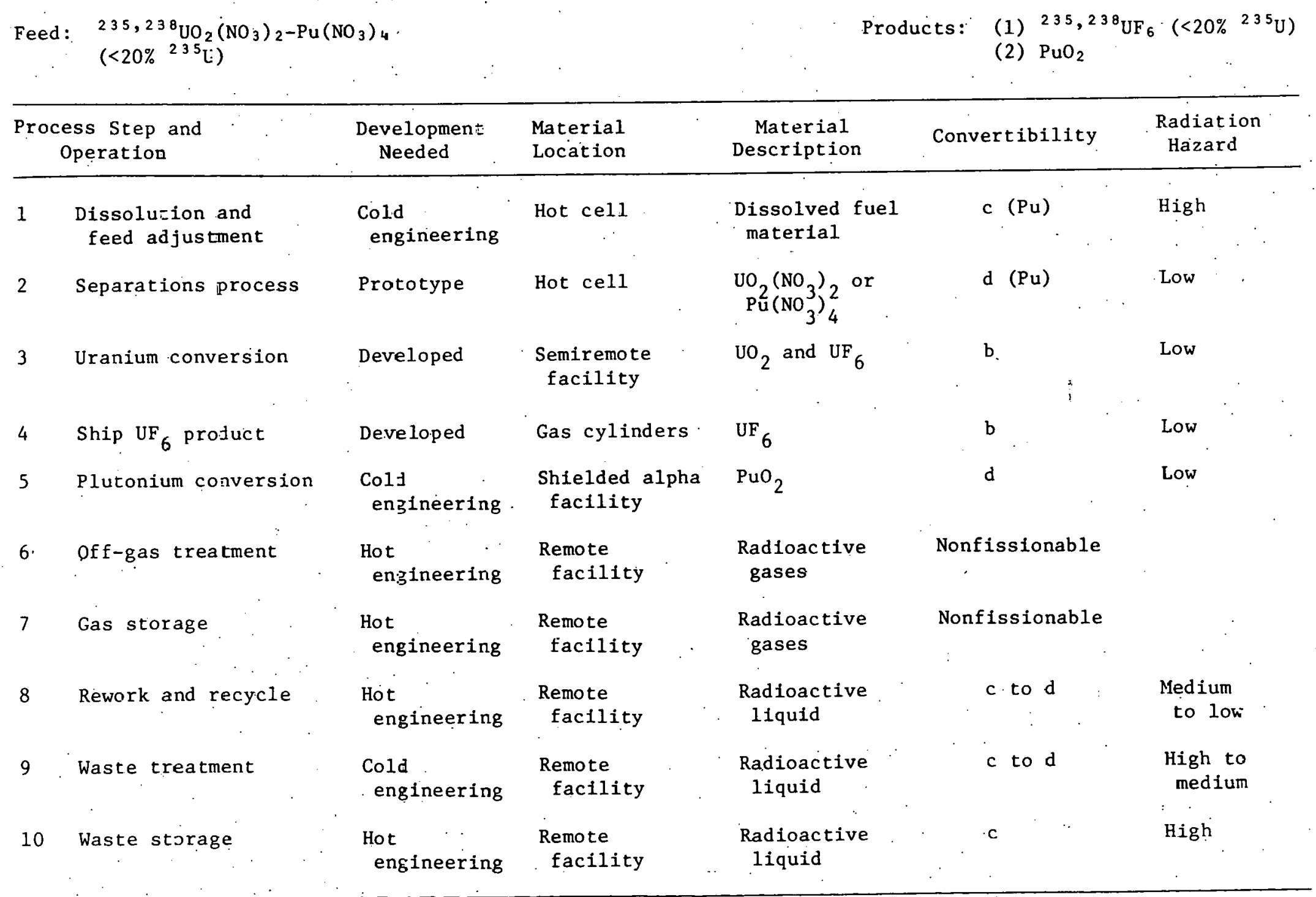


Table 4.4. Analysis for Reprocessing Scheme 1 for $>20 \%$. ${ }^{235} \mathrm{U}$
Feed: $\quad 235,238 \mathrm{UO}_{2}\left(\mathrm{NO}_{3}\right)_{2}-\mathrm{Pu}\left(\mathrm{NO}_{3}\right)_{4}\left(>20 \%{ }^{235} \mathrm{U}\right)$
Preducts:
(1) $235238 \mathrm{UF}_{6} \quad\left(>20 \%{ }^{235} \mathrm{U}\right)$
(2) $\mathrm{PuO}_{2}$

\begin{tabular}{|c|c|c|c|c|c|c|c|}
\hline & $\begin{array}{l}\text { cess Step and } \\
\text { Operation }\end{array}$ & $\begin{array}{l}\text { Development } \\
\text { Needed }\end{array}$ & $\begin{array}{l}\text { Material } \\
\text { Location }\end{array}$ & $\begin{array}{c}\text { Material } \\
\text { Description }\end{array}$ & Convertibility & $\begin{array}{l}\text { Radiation } \\
\text { Hazard }\end{array}$ & \\
\hline 1 & $\begin{array}{l}\text { Dissolution and } \\
\text { feed adjustment }\end{array}$ & $\begin{array}{l}\text { Cold } \\
\text { engineering }\end{array}$ & Hot cell & $\begin{array}{l}\text { Dissclved fuel } \\
\text { material. }\end{array}$ & c & High & \\
\hline 2 & $\begin{array}{l}\text { Separations } \\
\text { process }\end{array}$ & Pro:otype & Got cell & $\begin{aligned} \mathrm{UO}_{2}\left(\mathrm{UO}_{3}\right)_{2} & \text { or } \\
\mathrm{Pu}\left(\mathrm{UO}_{3}\right)_{4} & \text { solution }\end{aligned}$ & n & Low & \\
\hline 3 & Uranium conversion & Developed & $\begin{array}{l}\text { Semiremote } \\
\text { facility }\end{array}$ & $\mathrm{UO}_{2}$ and $\mathrm{UF}_{\epsilon}$ & d & Low & - \\
\hline 4 & Ship UF 6 procict & Developed & Gas cylinders & $\mathrm{UF}_{6}$ & d & Low & \\
\hline 5 & Plutonium conversion & $\begin{array}{l}\text { Cold } \\
\text { engineering }\end{array}$ & $\begin{array}{l}\text { Shielced a-pha } \\
\text { factlity }\end{array}$ & $\mathrm{PuO}_{2}$ & $d$ & Low & \\
\hline 6 & Ofí-gas treatment & $\begin{array}{l}\text { Hot } \\
\text { engineering }\end{array}$ & $\begin{array}{l}\text { Remote } \\
\text { facillty }\end{array}$ & $\begin{array}{l}\text { Radijactive } \\
\text { gases }\end{array}$ & Nonfissionable & & \\
\hline 7 & Gas storage & $\begin{array}{l}\text { Hot } \\
\text { engineering }\end{array}$ & $\begin{array}{l}\text { Remote } \\
\text { facility }\end{array}$ & $\begin{array}{l}\text { Radisactive } \\
\text { gases }\end{array}$ & Nonfissionable & & \\
\hline 8 & $\begin{array}{c}\text { Rework and recycle } \\
\text { : }\end{array}$ & $\begin{array}{l}\text { Hot } \\
\text { ergineering }\end{array}$ & $\begin{array}{l}\text { Remote } \\
\text { facility }\end{array}$ & $\begin{array}{l}\text { Radioactive } \\
\text { liquid }\end{array}$ & c to d & Medium & \\
\hline 9 & Waste treatment & $\begin{array}{l}\text { Colld } \\
\text { er.gineering }\end{array}$ & $\begin{array}{l}\text { Remote } \\
\text { facility }\end{array}$ & $\begin{array}{l}\text { Radioactive } \\
\text { liquid }\end{array}$ & $c$ to d & High & \\
\hline 10 & Waste storage & $\begin{array}{l}\text { Hot } \\
\text { eagineering }\end{array}$ & $\begin{array}{l}\text { Renote } \\
\text { facility }\end{array}$ & $\begin{array}{l}\text { Radioactive } \\
\text { liquid }\end{array}$ & c & High & \\
\hline
\end{tabular}


ORNL OWG. 77-1413

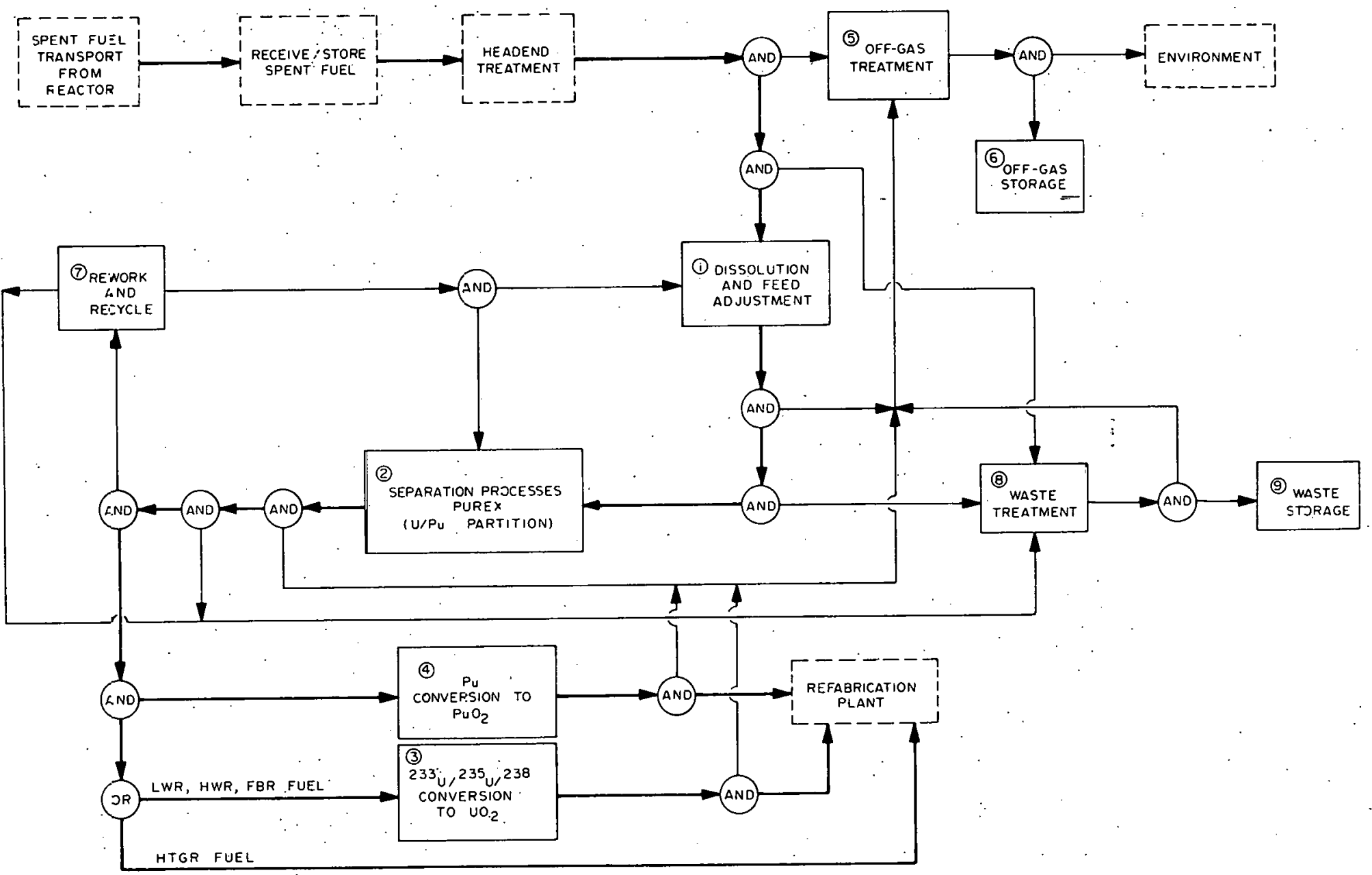

Fig. 4:9. Reprocessing scheme 2 - Level 1 Functional Flow Diagram: Reprocessing $\left({ }^{233} \mathrm{U},{ }^{238} \mathrm{U}\right) \mathrm{O}_{2} \mathrm{Fuel}$ by the Purex Process. Partition of uranium and plutonium. 
Fable 4.5. Analysis for Reprozessirig Scheme 2 for $<15 \%$-Enriched $23{ }^{3} \mathrm{U}$

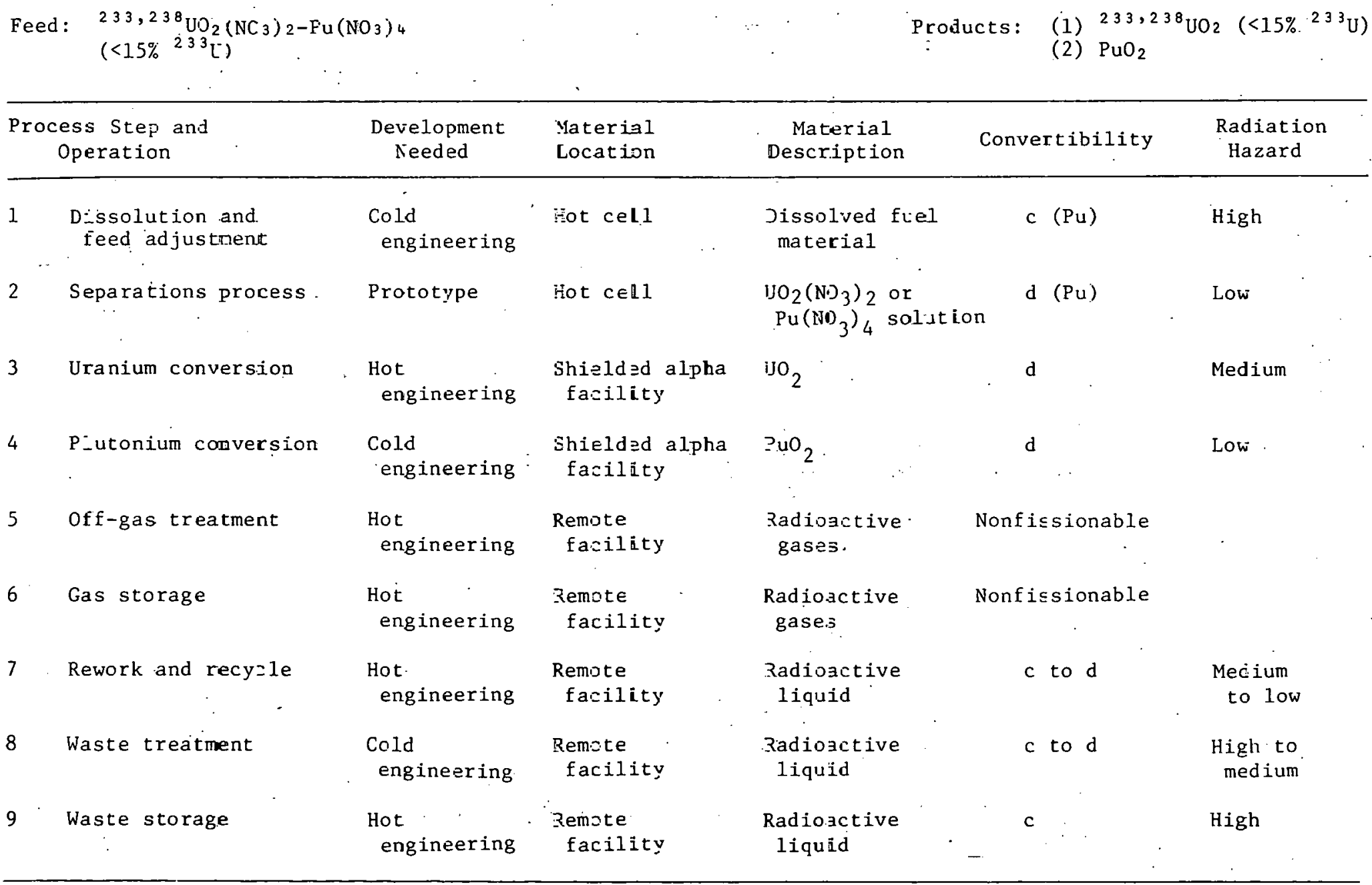


Table 4.6. Analysis for Reprocessing Scheme 2 for $>15 \%$-Enriched $23{ }^{3} \mathrm{Li}$

Feed: $\quad 233,238 \mathrm{UO}_{2}\left(\mathrm{NO}_{3}\right)_{2}-\mathrm{Pu}\left(\mathrm{NO}_{3}\right)_{4} \cdot\left(>15 \% \cdot{ }^{23} \mathrm{U}\right)$

Products: (1) ${ }^{233,23{ }^{8} \mathrm{UO}_{2}}$

(2) $\mathrm{PuO}_{2}$

\begin{tabular}{|c|c|c|c|c|c|c|}
\hline \multicolumn{2}{|c|}{$\begin{array}{l}\text { Process Step and } \\
\text { Operation }\end{array}$} & \multirow{2}{*}{$\begin{array}{l}\begin{array}{l}\text { Development } \\
\text { Needed }\end{array} \\
\begin{array}{l}\text { Cold } \\
\text { engineering }\end{array}\end{array}$} & \multirow{2}{*}{$\begin{array}{l}\text { Material } \\
\text { Location }\end{array}$} & \multirow{2}{*}{$\begin{array}{c}\text { Material } \\
\text { Description } \\
\begin{array}{c}\text { Dissolved fuel } \\
\text { materia! }\end{array}\end{array}$} & Convertibility & \multirow{2}{*}{$\begin{array}{c}\begin{array}{c}\text { Radiation } \\
\text { Hazard }\end{array} \\
\text { High }\end{array}$} \\
\hline 1 & $\begin{array}{l}\text { Dissolution and } \\
\text { feed adjustment }\end{array}$ & & & & c & \\
\hline 2 & $\begin{array}{l}\text { Separations } \\
\text { process }\end{array}$ & Prototype & Hot cell & $\begin{array}{l}\mathrm{UO}_{2}\left(\mathrm{NO}_{3}\right)_{2} \text { or } \\
\mathrm{Pu}\left(\mathrm{NO}_{3}\right)_{4} \text { solution }\end{array}$ & $\mathrm{d}(\mathrm{Pu})$ & Low \\
\hline 3 & Uranium conversion & $\begin{array}{l}\text { Hot } \\
\text { engineering }\end{array}$ & $\begin{array}{l}\text { Shielded alpha } \\
\text { facility }\end{array}$ & $\mathrm{UO}_{2}$ & $d^{*}$ & Medium \\
\hline 4 & Plutonium conversion & $\begin{array}{l}\text { Cold } \\
\text { enzineering }\end{array}$ & $\begin{array}{l}\text { Shielded alpha } \\
\text { facility }\end{array}$ & $\mathrm{PuO}_{2}$ & $\mathrm{~d}$ & Low \\
\hline 5 & off-gas treatment & $\begin{array}{l}\text { Hot } \\
\text { engineering }\end{array}$ & $\begin{array}{l}\text { Remote } \\
\text { facility }\end{array}$ & $\begin{array}{l}\text { Radioactive } \\
\text { gases }\end{array}$ & Nonfissionable & Medium \\
\hline 6 & Gas storage & $\begin{array}{l}\text { Hot } \\
\text { engineering }\end{array}$ & $\begin{array}{l}\text { Remote } \\
\text { facility }\end{array}$ & $\begin{array}{l}\text { Radioactive } \\
\text { gases }\end{array}$ & Nonfissionable & Mediun \\
\hline 7 & Rework and recycle & $\begin{array}{l}\text { Hot } \\
\text { engineering }\end{array}$ & $\begin{array}{l}\text { Remote } \\
\text { facility }\end{array}$ & $\begin{array}{l}\text { Radioactive } \\
\text { liquid }\end{array}$ & c to $d$ & $\begin{array}{l}\text { Medium } \\
\text { to low }\end{array}$ \\
\hline 8 & Waste treatment & $\begin{array}{l}\text { Cold } \\
\text { er:gineering }\end{array}$ & $\begin{array}{l}\text { Remote } \\
\text { facility. }\end{array}$ & $\begin{array}{l}\text { Radioactive } \\
\text { liquid }\end{array}$ & $c$ to $d$ & $\begin{array}{l}\text { High to } \\
\text { medium }\end{array}$ \\
\hline 9 & Waste storage & $\begin{array}{l}\text { Hot } \\
\text { engineering }\end{array}$ & $\begin{array}{l}\text { Remote } \\
\text { facility }\end{array}$ & $\begin{array}{l}\text { Radioactive } \\
\text { liquid }\end{array}$ & c & High \\
\hline
\end{tabular}

*A $10 \mathrm{~kg}$ bat:ch of ${ }^{233} \mathrm{U}$ in equilibrium with the daughters of the ${ }^{232} \mathrm{U}$ it contains would result in about 100 to $1000 \mathrm{R}$ radiation field at one foot distance. 


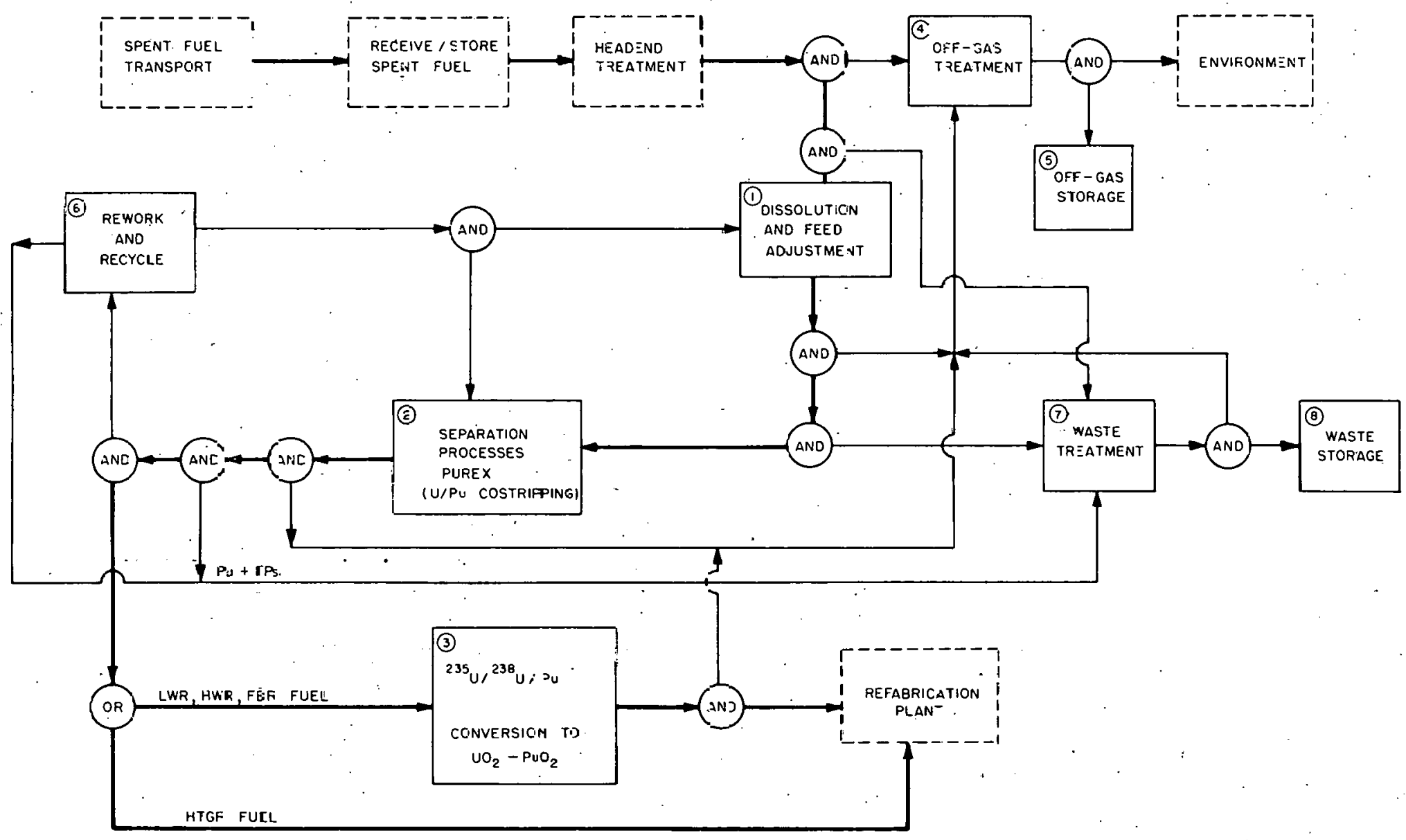

Fig. 4.10. Reprocessing Scheme 3 - Level 1 Functional Flow Diagram: Reprocessing $\left({ }^{23} \mathrm{U},{ }^{238} \mathrm{U}\right) \mathrm{O}_{2}-\mathrm{PuO}=$ Fuel by the Purex Process. Jastripping of Uranium and Plutonium. 
Table 4.7. Analysis for Reprocessing Scheme 3 HEU or LEU - Factors Determined by Plutonium Feed: $\quad 2.35,238 \mathrm{UO}_{2}\left(\mathrm{NO}_{3}\right)_{2}-\mathrm{Pu}\left(\mathrm{NO}_{3}\right)_{\mathrm{L}} * \quad$ Product: ${ }^{235,23.8} \mathrm{UO}_{2}-\mathrm{PuO}_{2}$

\begin{tabular}{|c|c|c|c|c|c|c|}
\hline \multicolumn{2}{|c|}{$\begin{array}{c}\text { Process Step and } \\
\text { Operation }\end{array}$} & \multirow{2}{*}{$\begin{array}{l}\begin{array}{l}\text { Development } \\
\text { Needed }\end{array} \\
\begin{array}{l}\text { Colld } \\
\text { ergineering }\end{array}\end{array}$} & \multirow{2}{*}{$\frac{\begin{array}{l}\text { Material } \\
\text { Location }\end{array}}{\text { Hot cell }}$} & \multirow{2}{*}{$\begin{array}{c}\begin{array}{c}\text { Material } \\
\text { Description }\end{array} \\
\begin{array}{c}\text { Dissolved fuel } \\
\text { material }\end{array}\end{array}$} & Convertibility & \multirow{2}{*}{$\frac{\begin{array}{l}\text { Radiation } \\
\text { Hazard }\end{array}}{\text { High }}$} \\
\hline 1. & $\begin{array}{l}\text { Dissolution and } \\
\text { feed adjustment }\end{array}$ & & & & c $\quad \cdots \quad=$ & \\
\hline 2 & Separations process & Pretotype & Hot cell & $\begin{array}{l}\mathrm{UO}_{2}\left(\mathrm{NO}_{3}\right)_{2}-\mathrm{Pu}\left(\mathrm{NO}_{3}\right)_{4} \\
\text { solution }\end{array}$ & d. & Low \\
\hline 3 & Conversion to MOX & $\begin{array}{l}\text { Cold } \\
\text { er:gineering }\end{array}$ & $\begin{array}{l}\text { Shielded alpha } \\
\text { facility }\end{array}$ & $\mathrm{UO}_{2}-\mathrm{PuO}_{2}$ & $d$ & Low \\
\hline 4 & of $f$-gas treatment & $\begin{array}{l}\text { Hot } \\
\text { ergineering }\end{array}$ & $\begin{array}{l}\text { Remote } \\
\text { facility }\end{array}$ & $\begin{array}{l}\text { Radioactive } \\
\text { gases }\end{array}$ & Nonfissionable & Medium \\
\hline 5 & Gas storage & $\begin{array}{l}\text { Hot } \\
\text { engineering }\end{array}$ & $\begin{array}{l}\text { Remote } \\
\text { facility }\end{array}$ & $\begin{array}{l}\text { Radioactive } \\
\text { gases }\end{array}$ & Nonfissionable & Medium \\
\hline 6 & Rework and rəcycle & $\begin{array}{l}\text { Hot } \\
\text { ergineering. }\end{array}$ & $\begin{array}{l}\text { Remote } \\
\text { facility }\end{array}$ & $\begin{array}{l}\text { Radioactive } \\
\text { liquid }\end{array}$ & c to $d$. & $\begin{array}{l}\text { Medium } \\
\text { to low }\end{array}$ \\
\hline 7 & Waste treatment & $\begin{array}{l}\text { Cold } \\
\text { engineering }\end{array}$ & $\begin{array}{l}\text { Remote } \\
\text { facility }\end{array}$ & $\begin{array}{l}\text { Radioactive } \\
\text { liquid }\end{array}$ & $c$ to $d$ & $\begin{array}{l}\text { High to } \\
\text { medium }\end{array}$ \\
\hline 8 & Waste storage & $\begin{array}{l}\text { Hot } \\
\text { engineëring }\end{array}$ & $\begin{array}{l}\text { Remote } \\
\text { facility }\end{array}$ & $\begin{array}{l}\text { Radioactive } \\
\text { liquid }\end{array}$ & $c$ & High \\
\hline
\end{tabular}

*The uranium can be any concentration of ${ }^{235} \mathrm{U}$ in ${ }^{238} \mathrm{U}$. 


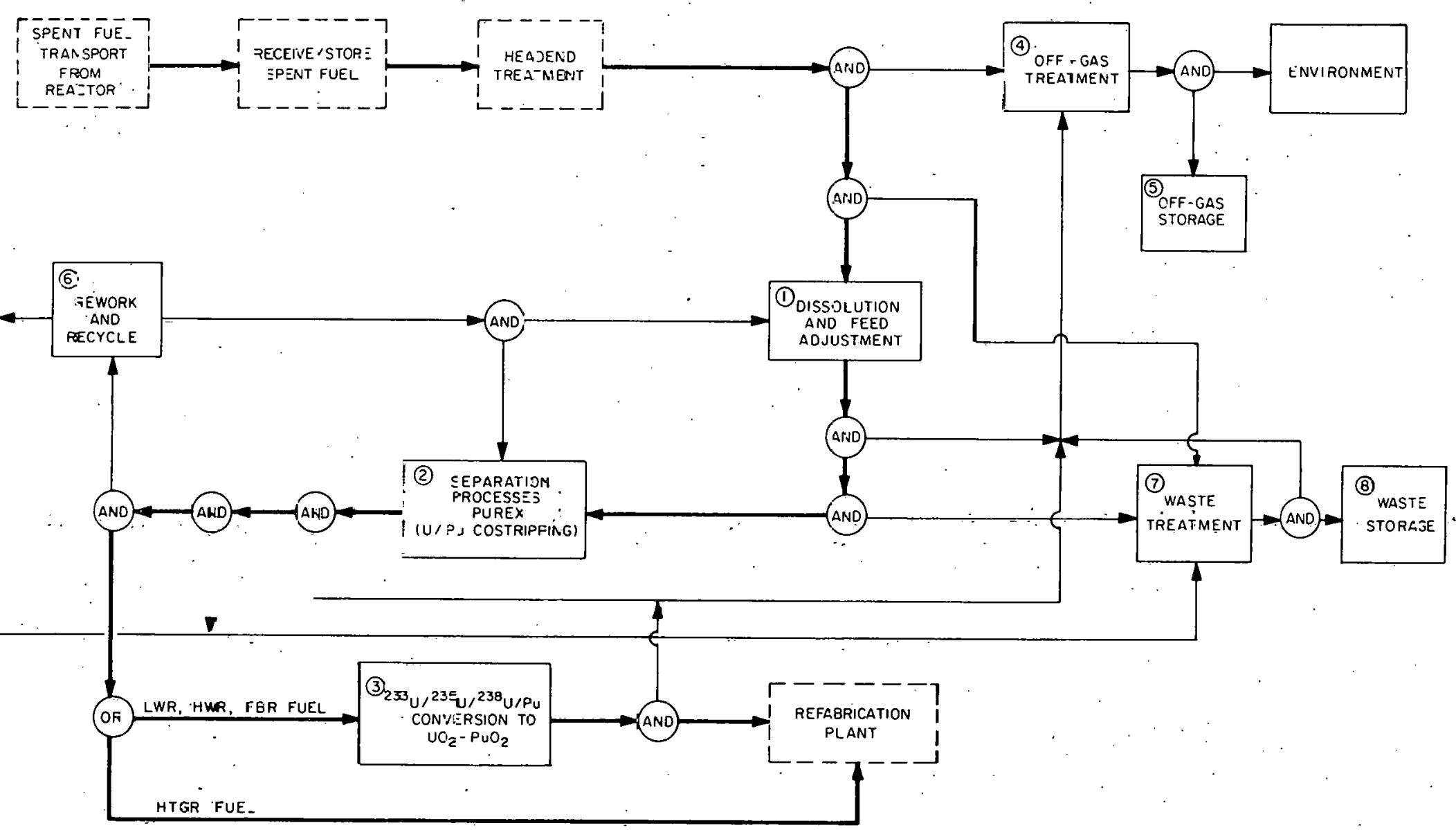

Fig. 4.11. Reprocessing Scheme 4-Leve- 1 Functional Flow Diagram: Reprocessing $\left({ }^{233} U,{ }^{235} U\right.$, $\left.{ }^{2}{ }^{38} \mathrm{U}\right) \mathrm{O}_{2}-\mathrm{PuO}_{2}$ Fuel by the Purex Process; Dostr-ppir.g. of Uranium and Plutonium. 
Table 4.\&. Analysis for Reprocessing Scheme 4 HEU or LEU - Factors Determined by Plutonium

\begin{tabular}{|c|c|c|c|c|c|c|}
\hline \multicolumn{2}{|c|}{$\begin{array}{c}\text { Process Step and } \\
\text { Operation }\end{array}$} & \multirow{2}{*}{$\begin{array}{l}\begin{array}{c}\text { Development } \\
\text { Needed }\end{array} \\
\begin{array}{c}\text { Cold } \\
\text { engineering }\end{array}\end{array}$} & \multirow{2}{*}{$\begin{array}{l}\text { Material } \\
\text { Location }\end{array}$} & \multirow{2}{*}{$\begin{array}{c}\begin{array}{c}\text { Material } \\
\text { Description }\end{array} \\
\begin{array}{c}\text { Dissolved fuel } \\
\text { material }\end{array}\end{array}$} & Convertibility & \multirow{2}{*}{$\begin{array}{l}\begin{array}{c}\text { Radiation } \\
\text { Hazard }\end{array} \\
\text { High }\end{array}$} \\
\hline- & $\begin{array}{l}\text { Dissolution and } \\
\text { feed adjustment }\end{array}$ & & & & c & \\
\hline 2 & Separations process & Prototype & Hot cell & $\begin{array}{l}\mathrm{UO}_{2}\left(\mathrm{NO}_{3}\right) 2^{-} \\
\quad \mathrm{Pu}\left(\mathrm{NO}_{3}\right)_{4} \text { solut }\end{array}$ & on & Low \\
\hline 3 & MOX conversion & $\begin{array}{l}\text { Cold } \\
\text { engineering }\end{array}$ & $\begin{array}{c}\text { Semiremote } \\
\text { facility }\end{array}$ & $\mathrm{UO}_{2}-\mathrm{PuO}_{2}$ & d $\quad \vdots$ & Low \\
\hline 4 & Off-gas treatment & $\begin{array}{l}\text { Hot } \\
\text { engineering }\end{array}$ & $\begin{array}{l}\text { Remote } \\
\text { facility }\end{array}$ & $\begin{array}{l}\text { Radioactive } \\
\text { gases }\end{array}$ & Nonfissionable & Medium \\
\hline 5 & Gas storage & $\begin{array}{l}\text { Hot } \\
\text { engineering }\end{array}$ & $\begin{array}{l}\text { Remote } \\
\text { facility }\end{array}$ & $\begin{array}{l}\text { Radioactive } \\
\text { gases }\end{array}$ & Nonfissionable & Medium: \\
\hline 6 & $\begin{array}{l}\text { Rework and } \\
\text { recjele }\end{array}$ & $\begin{array}{l}\text { Hot } \\
\text { engineering }\end{array}$ & $\begin{array}{l}\text { Remote } \\
\text { facility }\end{array}$ & $\begin{array}{l}\text { Radioactive } \\
\text { liquid }\end{array}$ & c to d & $\begin{array}{l}\text { Medium } \\
\text { to } 10 \text { w }\end{array}$ \\
\hline$?$ & Waste treatment & $\begin{array}{l}\text { Cold } \\
\text { engineering }\end{array}$ & $\begin{array}{l}\text { Remote } \\
\text { facility }\end{array}$ & $\begin{array}{l}\text { Radioactive } \\
\text { liquid }\end{array}$ & c to d & $\begin{array}{l}\text { High to } \\
\text { medium }\end{array}$ \\
\hline 8 & Waste stcrage & $\begin{array}{l}\text { Hot } \\
\text { engineering }\end{array}$ & $\begin{array}{l}\text { Remote } \\
\text { facility }\end{array}$ & $\begin{array}{l}\text { Radioactive } \\
\text { liquid }\end{array}$ & c & High \\
\hline
\end{tabular}

*The uranium can be any concentration of ${ }^{233} \mathrm{U}$ in ${ }^{238} \mathrm{U}$. 
ORNL OWG. 77-1410

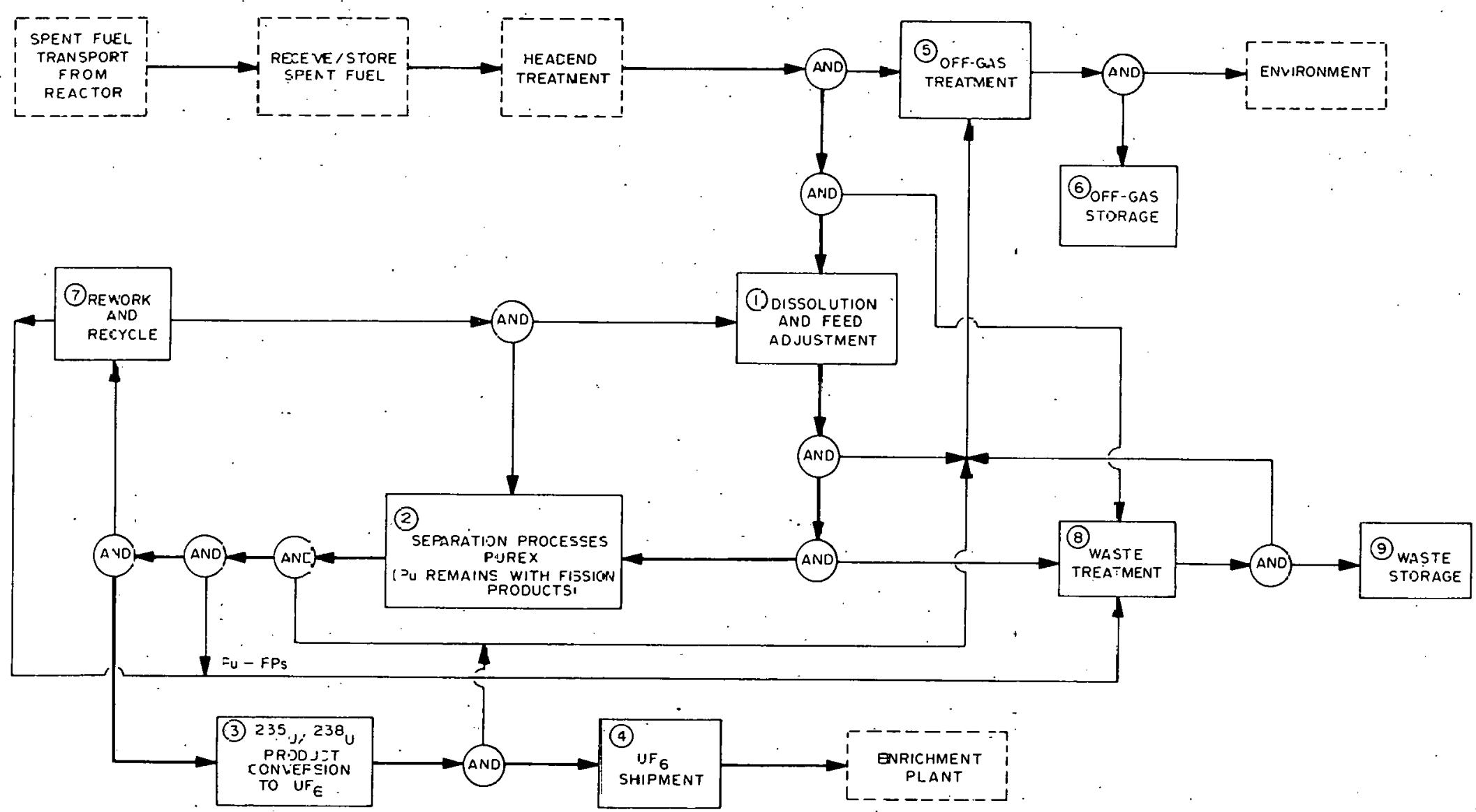

Fig. 4.12. Reprocessing Scheme 5 - Leve1 1 Functional Flow Diagran:- Reprocessing $\left({ }^{235} \mathrm{U},{ }^{238} \mathrm{U}-\mathrm{Pu}\right) \mathrm{O}_{2}$ Fuel by the Purex Process. Plutonium stowaway with iission products. 
Table 4.9. Anılysis for Reprocessing Scheme 5 for $<20 \%$-Enriched ${ }^{23} \mathrm{U}$

Feed: $\quad 235,233 \mathrm{UO}_{2}\left(\mathrm{NO}_{3}\right)_{2}-\mathrm{Pu}\left(\mathrm{NO}_{3}\right)_{4}\left(<20 \%{ }^{235} \mathrm{U}\right)$

Product: (1) $235,238 \mathrm{UF}_{6}\left(<20 \%{ }^{235} \mathrm{U}\right)$

Plutionium to aqueous waste for storage

\begin{tabular}{|c|c|c|c|c|c|c|}
\hline \multicolumn{2}{|c|}{$\begin{array}{l}\text { Process Step and } \\
\text { Operation }\end{array}$} & \multirow{2}{*}{$\begin{array}{l}\begin{array}{c}\text { Development } \\
\text { Needed }\end{array} \\
\begin{array}{c}\text { Cold } \\
\text { engineerirg }\end{array}\end{array}$} & \multirow{2}{*}{$\begin{array}{l}\text { Material } \\
\text { Location }\end{array}$} & \multirow{2}{*}{$\begin{array}{c}\begin{array}{c}\text { Material } \\
\text { Description }\end{array} \\
\begin{array}{c}\text { Dissolved fuel } \\
\text { material }\end{array}\end{array}$} & Convertibility & \multirow{2}{*}{$\frac{\begin{array}{c}\text { Radiacion } \\
\text { Hazard }\end{array}}{\text { High }}$} \\
\hline 1 & $\begin{array}{l}\text { Dissolution and } \\
\text { feed adjustment }\end{array}$ & & & & c $(\mathrm{Pu})$ & \\
\hline 2 & Separations process & Procotype & Hot cell & $\begin{array}{r}\mathrm{UO}_{2}\left(\mathrm{NO}_{3}\right)_{2} \\
\text { solution }\end{array}$ & $b *$ & Low \\
\hline 3 & $\begin{array}{c}\text { Uranium =onversion } \\
\end{array}$ & Developed & $\begin{array}{l}\text { Semiremote } \\
\text { facility }\end{array}$ & $\mathrm{UO}_{2}$ and $\mathrm{UF}_{6}$ & $b$ & Low \\
\hline 4 & Ship $U F_{6}$ product & Developed & Gas cylinders & $\mathrm{UF}_{6}$ & $\mathrm{~b}$ & Low \\
\hline 5 & Off-gas treatment & $\begin{array}{l}\text { Hot } \\
\text { engineering }\end{array}$ & $\begin{array}{l}\text { Remote } \\
\text { facility }\end{array}$ & $\begin{array}{l}\text { Radioactive } \\
\text { gases }\end{array}$ & Nonfissionable & Medium \\
\hline 6 & Gas storage & $\begin{array}{l}\text { Hot } \\
\text { engineering }\end{array}$ & $\begin{array}{l}\text { Remote } \\
\text { facility }\end{array}$ & $\begin{array}{l}\text { Radioactive } \\
\text { gases }\end{array}$ & Nonfissionable & Medium \\
\hline 7 & Rework and recycle & $\begin{array}{l}\text { Hot } \\
\text { engineering }\end{array}$ & $\begin{array}{l}\text { Remote } \\
\text { facility }\end{array}$ & $\begin{array}{l}\text { Radioactive } \\
\text { liquid }\end{array}$ & $b$ & $\begin{array}{l}\text { Medium } \\
\text { to low }\end{array}$ \\
\hline 8 & Waste treatment & $\begin{array}{l}\text { Cold } \\
\text { engineering }\end{array}$ & $\begin{array}{l}\text { Remote } \\
\text { facility }\end{array}$ & $\begin{array}{l}\text { Radioactive } \\
\text { liquid }\end{array}$ & c to $d$ & $\begin{array}{l}\text { High to. } \\
\text { medium }\end{array}$ \\
\hline 9 & Waste storage & $\begin{array}{l}\text { Hot } \\
\text { engineering }\end{array}$ & $\begin{array}{l}\text { Remote } \\
\text { facility }\end{array}$ & $\begin{array}{l}\text { Radioactive } \\
\text { liquid }\end{array}$ & c & High \\
\hline
\end{tabular}

*With relatively simple changes in the separations process flowsheet the plutonium could be recovered in a form that would enhance relative attractiveness. 
Table 4.10. Analysis โo Reprocessing Scheme 5 for $>20 \%$-Enriched $235 \mathrm{U}$

\begin{tabular}{|c|c|c|c|c|c|c|}
\hline \multicolumn{2}{|c|}{$\begin{array}{c}\text { Process Step and } \\
\text { Opezation }\end{array}$} & \multirow{2}{*}{$\begin{array}{l}\text { Development } \\
\text { Needed }\end{array}$} & \multirow{2}{*}{$\begin{array}{l}\text { Material } \\
\text { Location }\end{array}$} & \multirow{2}{*}{$\begin{array}{c}\begin{array}{c}\text { Material } \\
\text { Description }\end{array} \\
\begin{array}{c}\text { Dissolved Fuə1 } \\
\text { material }\end{array}\end{array}$} & Convertibility & \multirow{2}{*}{$\begin{array}{c}\begin{array}{c}\text { Radiation } \\
\text { Hazard }\end{array} \\
\text { High }\end{array}$} \\
\hline 1 & $\begin{array}{l}\text { Dissolution and } \\
\text { feed adjus zment }\end{array}$ & & & & c $(\mathrm{Pu})$ & \\
\hline 2 & Separations process & Prototype & Hot $=e 11$ & $\begin{array}{l}\mathrm{UO}_{i}\left(\mathrm{NO}_{3}\right)_{2} \\
\text { scilution }\end{array}$ & $d^{*}$ & Low \\
\hline 3 & Uraniun cenrersion & Developed & $\begin{array}{l}\text { Semiremote } \\
\text { Eacility }\end{array}$ & $\mathrm{UO}_{z}$, and $\mathrm{UF}_{6}$ & $d$ & Low \\
\hline 4 & Siip UF 6 product & Developed & Gas sylirders & $\mathrm{UF}_{6}$ & $d$ & Low \\
\hline 5 & OEf-gas treatmer: " & $\begin{array}{l}\text { Hct } \\
\text { engineering }\end{array}$ & $\begin{array}{l}\text { Remote } \\
\text { facility }\end{array}$ & $\begin{array}{l}\text { Racioactive } \\
\text { gases }\end{array}$ & Nonfissionable & Medium \\
\hline 6 & Gas storage & $\begin{array}{l}\text { Hot } \\
\text { engineering }\end{array}$ & $\begin{array}{l}\text { Remote } \\
\text { facility }\end{array}$ & $\begin{array}{l}\text { Racioactive } \\
\text { gases }\end{array}$ & Nonfissionable & Medium \\
\hline 7 & Rework and reçcle & $\begin{array}{l}\text { Hot } \\
\text { engineering }\end{array}$ & $\begin{array}{l}\text { Remote } \\
\text { facility }\end{array}$ & $\begin{array}{l}\text { Racioactive } \\
\text { liquid }\end{array}$ & $c$ to $d$ & $\begin{array}{l}\text { Medium to } \\
\text { low }\end{array}$ \\
\hline 8 & Waste treatmen: & $\begin{array}{l}\text { Cold } \\
\text { engineering }\end{array}$ & $\begin{array}{l}\text { Remote } \\
\text { facility }\end{array}$ & $\begin{array}{l}\text { Racioactive } \\
\text { liquid }\end{array}$ & c to d & $\begin{array}{l}\text { High to } \\
\text { medium }\end{array}$ \\
\hline 9 & Waste storage & $\begin{array}{l}\text { Hot } \\
\text { engineering }\end{array}$ & $\begin{array}{l}\text { Remote } \\
\text { Eacility }\end{array}$ & $\begin{array}{l}\text { Racioactive } \\
\text { I=quid }\end{array}$ & c & $\mathrm{High}$ \\
\hline
\end{tabular}

*Plutonium caula be recovered by making relativeiy simple flowsheet changes, but this would not increase the relative attractiveness. 
ORNL OWG 77.1409

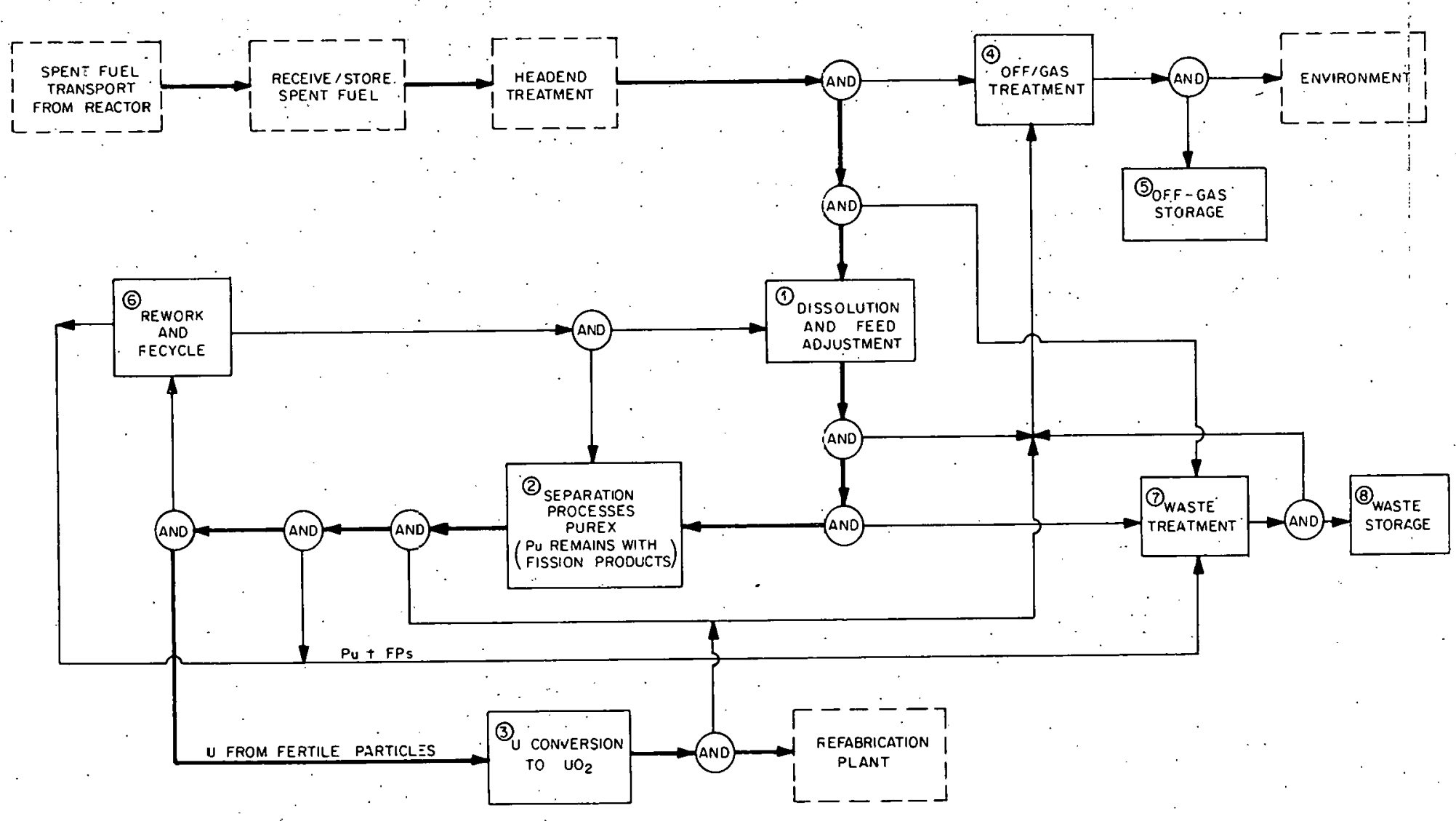

Fig. 4.13. Reprocessing Scheme 6-Leve1 1 Functional Flow Diagram: Reprocessing $\left({ }^{3}{ }^{3} \mathrm{U},{ }^{38} \mathrm{U}\right) \mathrm{O}_{2}-\mathrm{PuO}_{2}$ Fuel by the Purex Process. Plutonium stowaway with fission products. 
Tabl $\supseteq 4.11$. Aralysis fcr Reprocessirg Scheme 6 for $: 15 \%$-Enriched ${ }^{23} \mathrm{U}$

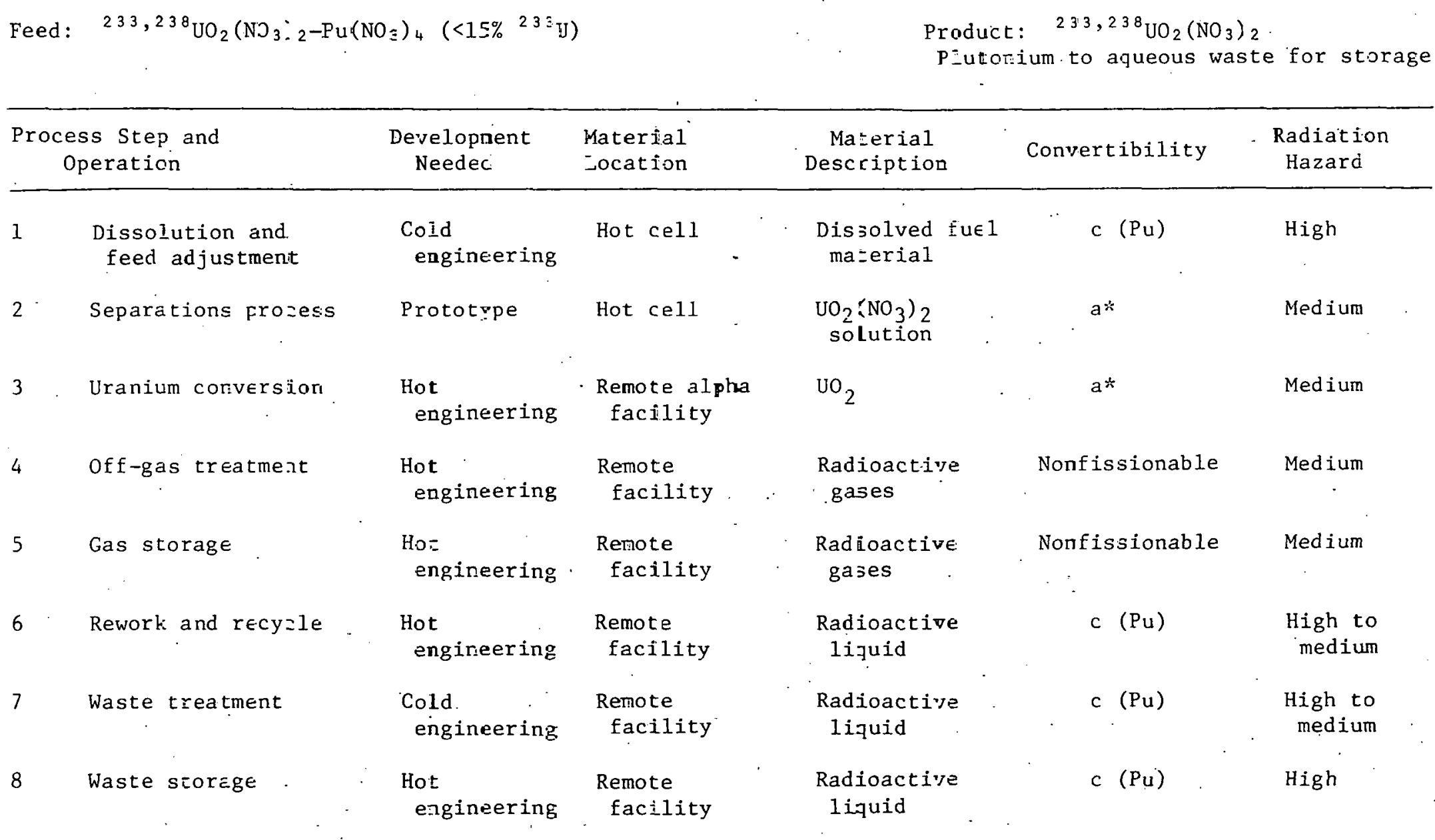

*With relatively simple changes in the separations process flowsheet the plutonium could be recovered. 
Table 4.12. Analysis for Reprocessing Scheme 6 for $>15 \%$-Enriched ${ }^{23} \mathrm{U}$

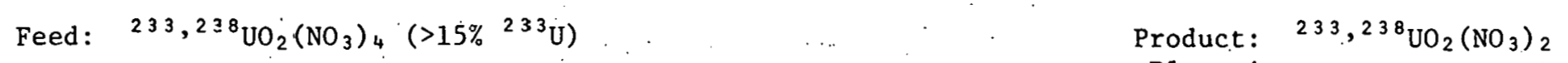

Plutonium to aqueous waste for storage

\begin{tabular}{|c|c|c|c|c|c|c|}
\hline \multicolumn{2}{|c|}{$\begin{array}{l}\text { Process Step and } \\
\therefore \text { Operation }\end{array}$} & \multirow{2}{*}{$\begin{array}{l}\begin{array}{l}\text { Development } \\
\text { Needed }\end{array} \\
\text { Ccld } \\
\text { engineering }\end{array}$} & \multirow{2}{*}{$\frac{\begin{array}{l}\text { Material } \\
\text { Location }\end{array}}{\text { Hot cell }}$} & \multirow{2}{*}{$\frac{\begin{array}{c}\text { Material } \\
\text { Description }\end{array}}{\begin{array}{c}\text { Dissolved fuel } \\
\text { material }\end{array}}$} & Convertibility & \multirow{2}{*}{$\begin{array}{l}\begin{array}{c}\text { Radiation } \\
\text { Hazard }\end{array} \\
\text { High } \\
\because\end{array}$} \\
\hline 1. & $\begin{array}{l}\text { Dissolction and } \\
\text { feed adjustment }\end{array}$ & & & & $c$ & \\
\hline 2 & Separations process & Prototype & Hot cell & $\begin{array}{r}\mathrm{UO}_{2}\left(\mathrm{NO}_{3}\right)_{2} \\
\text { solution }\end{array}$ & $\therefore c^{*}$ & Medium \\
\hline 3 & Uraniun conversion & $\begin{array}{l}\text { Hct } \\
\text { engineering }\end{array}$ & $\begin{array}{l}\text { Remote alpha } \\
\text { facility }\end{array}$ & $\mathrm{UO}_{2}$ & $\mathrm{~d} \cdot \mathrm{t}$ & Medium \\
\hline 4 & off-gas treatment & $\begin{array}{l}\text { Ho.t } \\
\text { engineering }\end{array}$ & $\begin{array}{l}\text { Remote } \\
\text { facility }\end{array}$ & $\begin{array}{l}\text { Radioactive } \\
\text { gases }\end{array}$ & Nonfissionable & Medium \\
\hline 5 & Gas storage & $\begin{array}{l}\text { Hot } \\
\text { engineering }\end{array}$ & $\begin{array}{l}\text { Remote } \\
\text { facility }\end{array}$ & $\begin{array}{l}\text { Radioactive } \\
\text { gases }\end{array}$ & Nonfissionable & Medium \\
\hline 6 & Rework and recycle & $\begin{array}{l}\text { Hot } \\
\text { engineering }\end{array}$ & $\begin{array}{l}\text { Remote } \\
\text { facility }\end{array}$ & $\begin{array}{l}\text { Radioactive } \\
\text { liquid }\end{array}$ & c & $\begin{array}{l}\text { High to } \\
\text { medium }\end{array}$ \\
\hline 7 & Waste treatment & $\begin{array}{l}\text { Cold } \\
\text { engineering }\end{array}$ & $\begin{array}{l}\text { Remote } \\
\text { facility }\end{array}$ & $\begin{array}{l}\text { Radioactive } \\
\text { liquid }\end{array}$ & c & $\begin{array}{l}\text { High to } \\
\text { medium }\end{array}$ \\
\hline 8 & Waste storage & $\begin{array}{l}\text { Hot } \\
\text { engineering }\end{array}$ & $\begin{array}{l}\text { Remote } \\
\text { facility }\end{array}$ & $\begin{array}{l}\text { Radioactive } \\
\text { liquid }\end{array}$ & c & Higin \\
\hline
\end{tabular}

*With relatively simple changes in the separations process flowsheet the plutonium could be recovered. tA $10 \mathrm{~kg}$ batch of ${ }^{233} \mathrm{U}$ in equilibrium with the daughters of the ${ }^{232} \mathrm{U}$ it contains would result in a 100 to $1000 \mathrm{R}$ radiation field at one foot distance. 


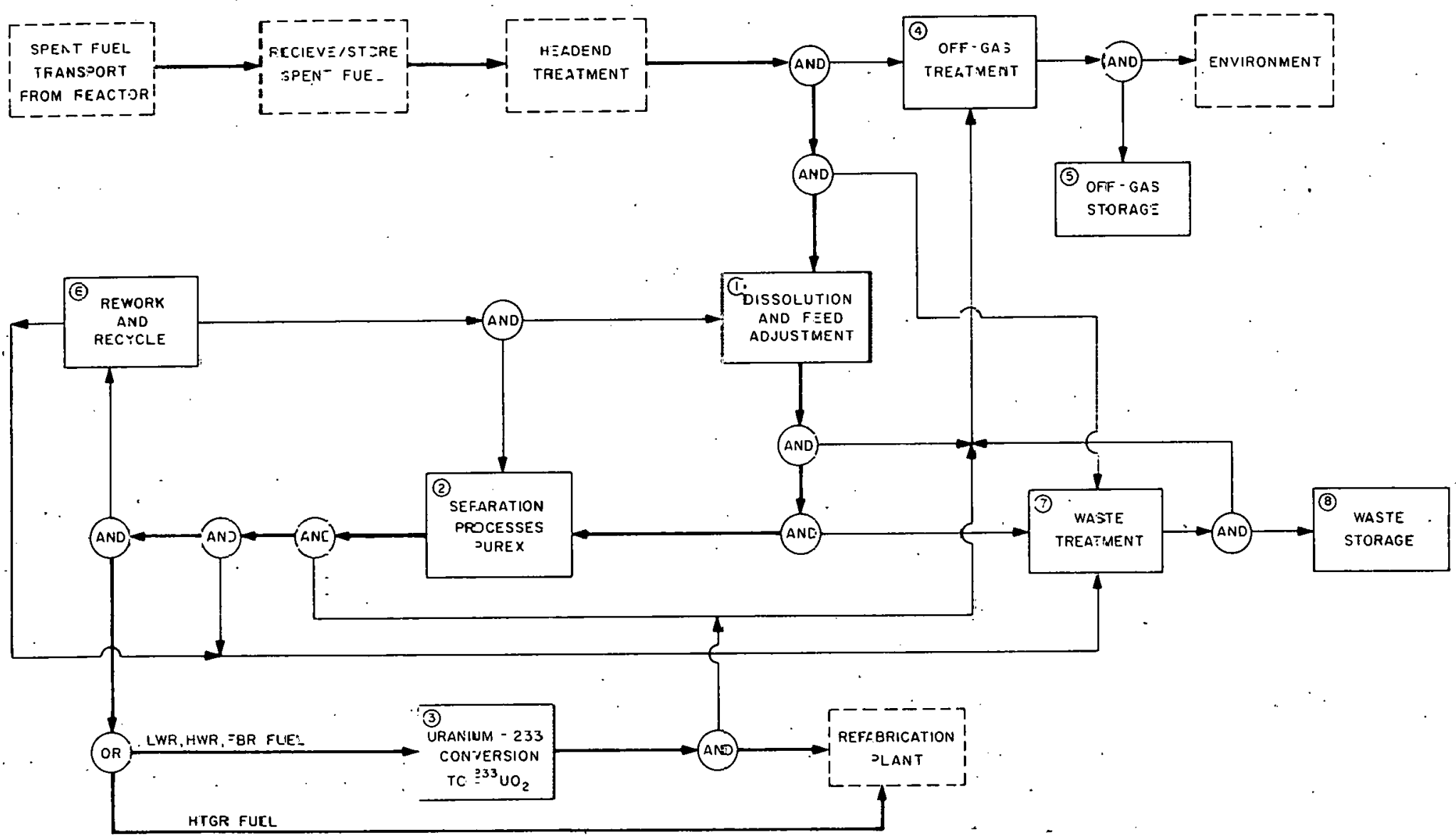

Fig. 4.14. Reprocessing 3cheme? - Level 1 Functional Flow Diagram: Reprocessing ${ }^{23} \mathrm{UO}_{2}$ Fuel by the Purex Proce:s. 
Table 4.13. Analysis for Reprocessing Scheme 7

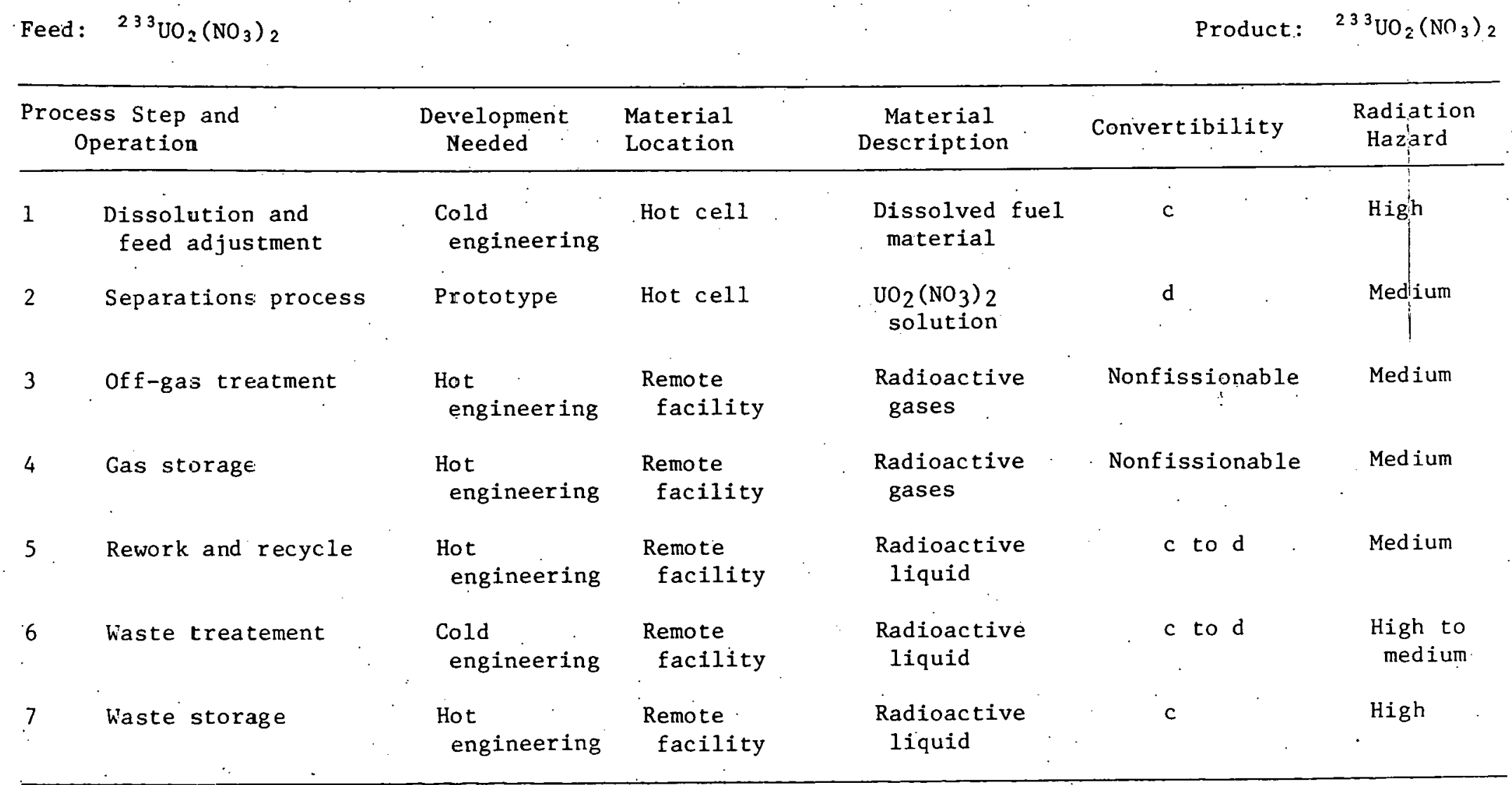

${ }^{*} 10 \mathrm{~kg}$ batch of ${ }^{23{ }^{3} \mathrm{U}}$ in equilibrium with the daughters of the ${ }^{232} \mathrm{U}$ it contains would result in about 100 to $1000 \mathrm{R}$ radiation field at one foot distance. 


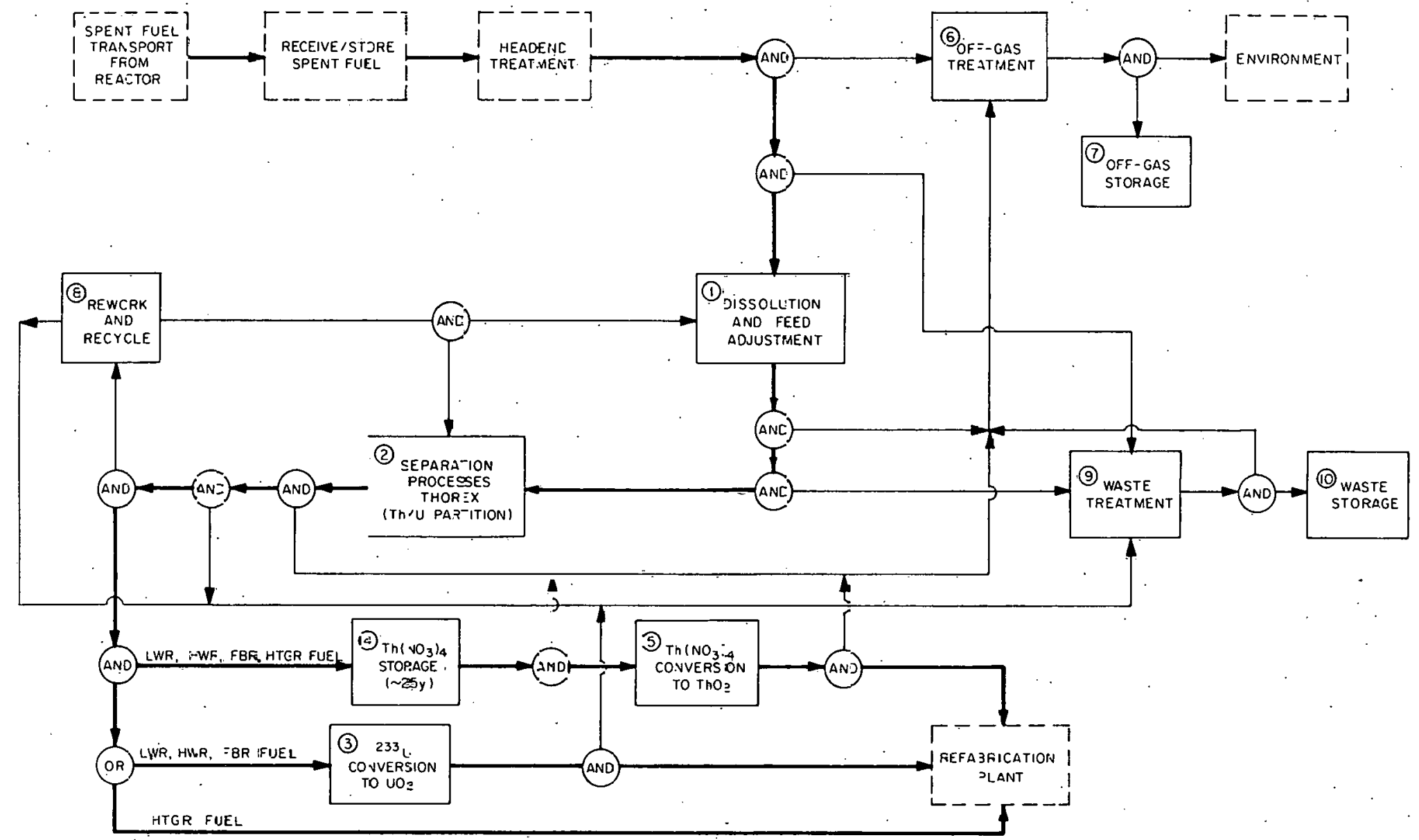

Fig. 4.15. Reprocessing Scheme 3-Level 1 Functional Flow Diagram: Reprocessing ${ }^{23}{ }^{3} \mathrm{UO}_{-} \mathrm{ThO}_{2}$ Fuel by the Thor $\in \mathrm{x}$ Process. Partition of thorium and uranium. 
Table 4.14, Analysis for Reprocessing Scheme 8

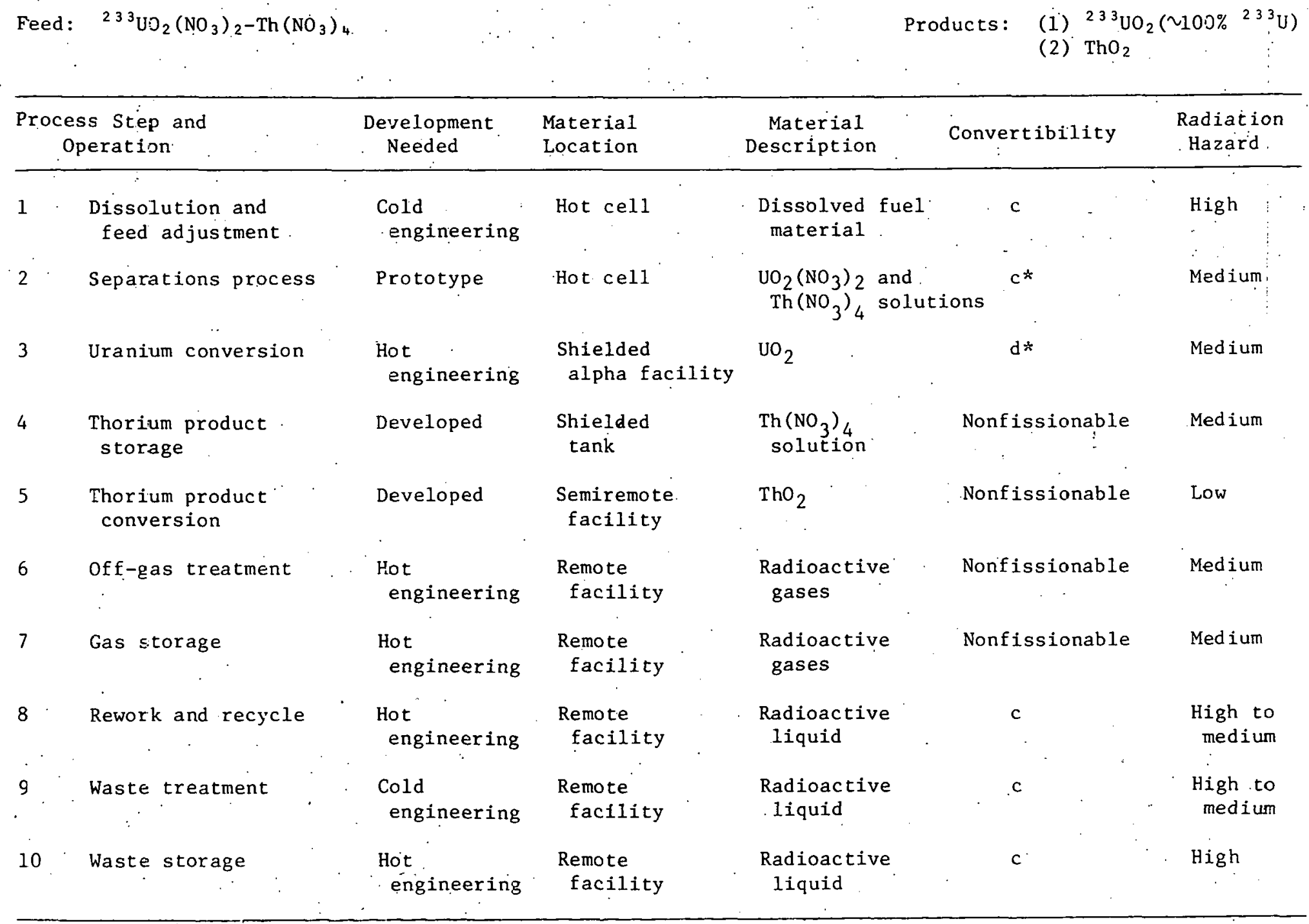

$*_{\mathrm{A}} 10 \mathrm{~kg}$ batch of ${ }^{233} \mathrm{U}$ in equilibrium with the daughters of the ${ }^{232} \mathrm{U}$ it contains would result in about a 100 to $1000 \mathrm{R}$ radiation fielc at one foot distance. 
ORNL DWG. 77-1406

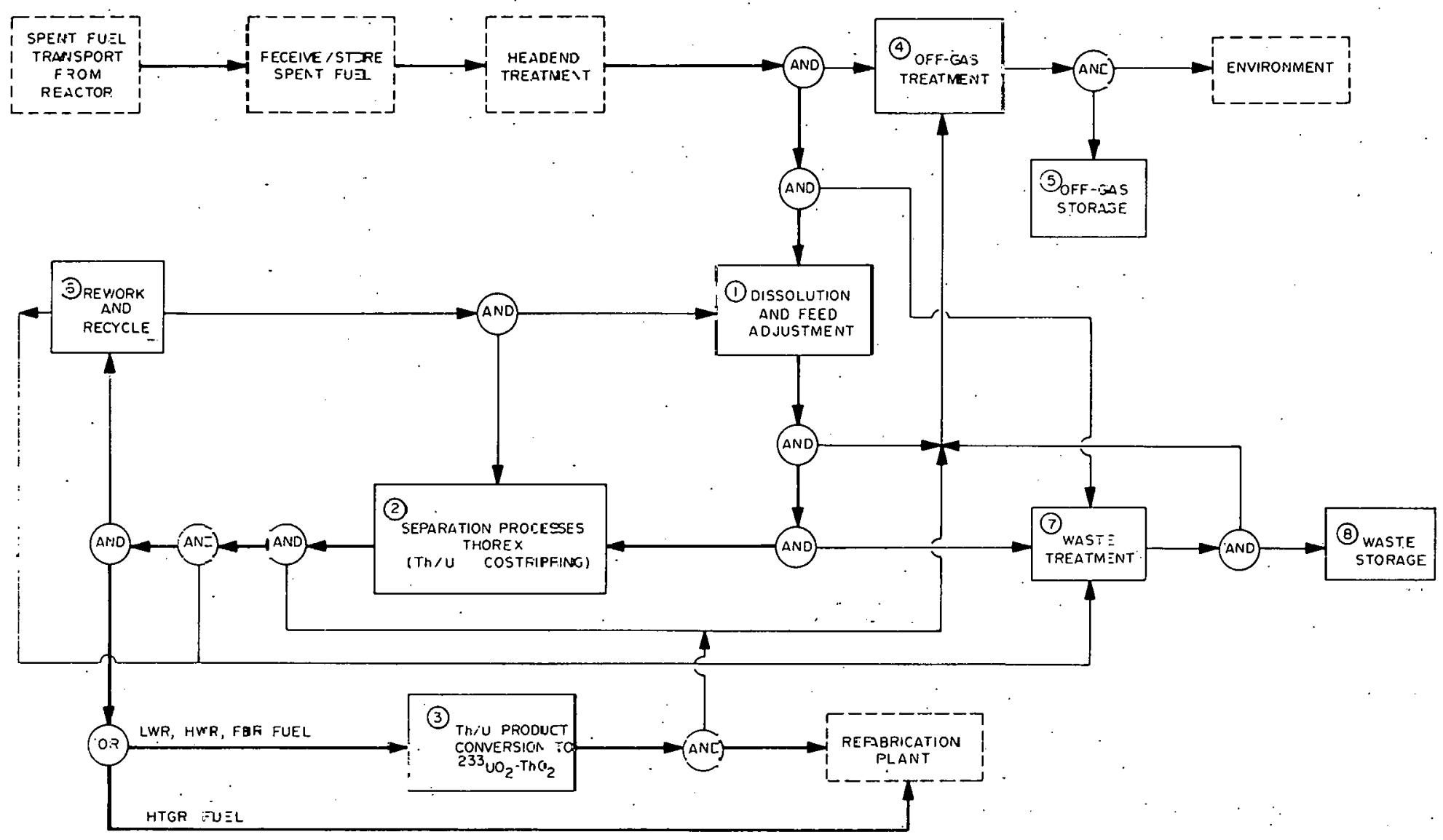

Fig. 4.16. Reprocessing Scheme 7 - Level 1 Functioral Flcw Iiagram: Reprocessing $2{ }^{3} \mathrm{UO}^{-\mathrm{ThO}_{2}}$ Fuel by the Thorex Process. Costrifping of Thorium and Uranium. 
Table 4.15. Analysis for Reprocessing Scheme 9

\begin{tabular}{|c|c|c|c|c|c|c|}
\hline \multicolumn{2}{|c|}{$\begin{array}{c}\text { Process Step and } \\
\text { Operation }\end{array}$} & $\begin{array}{l}\text { Development } \\
\text { Needed }\end{array}$ & $\begin{array}{l}\text { Material } \\
\text { Location }\end{array}$ & $\begin{array}{c}\text { Material } \\
\text { Description }\end{array}$ & Convertibility & $\begin{array}{l}\text { Radiation } \\
\text { Hazard }\end{array}$ \\
\hline$I$ & $\begin{array}{l}\text { Dissolution and } \\
\text { feed adjustment }\end{array}$ & $\begin{array}{l}\text { Cold } \\
\text { engineering }\end{array}$ & Hot cell & $\begin{array}{l}\text { Dissolved fuel } \\
\text { material }\end{array}$ & $c^{-}$ & High \\
\hline 2 & Separations process & Prototype & Hot cell & $\begin{array}{l}\mathrm{UO}_{2}\left(\mathrm{NO}_{3}\right) 2_{2}-\mathrm{Th}\left(\mathrm{NO}_{3}\right)_{4} \\
\text { sollution }\end{array}$ & $c^{*}$ & Medium \\
\hline 3 & Product conversion & $\begin{array}{l}\text { Hot } \\
\text { engineering }\end{array}$ & $\begin{array}{l}\text { Shielded alphà } \\
\text { facility }\end{array}$ & $\mathrm{UO}_{2}-\mathrm{ThO}_{2}$ & $c^{*}$ & Medium \\
\hline 4 & off-gas treatment. & $\begin{array}{l}\text { Hot } \\
\text { engineering }\end{array}$ & $\begin{array}{l}\text { Remote } \\
\text { facility }\end{array}$ & $\begin{array}{l}\text { Radioactive } \\
\text { gases }\end{array}$ & Nonfissionable & Medium \\
\hline 5 & Gas storage & $\begin{array}{l}\text { Ho: } \\
\text { engineering }\end{array}$ & $\begin{array}{l}\text { Remote } \\
\text { facility }\end{array}$ & $\begin{array}{l}\text { Radioactive } \\
\text { gases }\end{array}$ & Nonfissionable & Medium \\
\hline 6 & Rework and recycle. & $\begin{array}{l}\text { Ho= } \\
\text { engineering }\end{array}$ & $\begin{array}{l}\text { Remote } \\
\text { facility }\end{array}$ & $\begin{array}{l}\text { Radioactive } \\
\text { liquid }\end{array}$ & c & $\begin{array}{l}\text { High to } \\
\text { medium }\end{array}$ \\
\hline 7. & Waste treatment & $\begin{array}{l}\text { Cold } \\
\text { engineering }\end{array}$ & $\begin{array}{l}\text { Remote } \\
\text { facility }\end{array}$ & $\begin{array}{l}\text { Radioactive } \\
\text { liquid }\end{array}$ & c & $\begin{array}{l}\text { High: to } \\
\text { medium }\end{array}$ \\
\hline 8 & Waste storage & $\begin{array}{l}\text { Hot } \\
\text { engineering }\end{array}$ & $\begin{array}{l}\text { Remote } \\
\text { facility }\end{array}$ & $\begin{array}{l}\text { Radioactive } \\
\text { liquid }\end{array}$ & c & $\mathrm{High}$ \\
\hline
\end{tabular}

${ }^{*} \mathrm{~A} 10 \mathrm{~kg}$ batch of ${ }^{233} \mathrm{U}$ in equilibrium with the daughters of the ${ }^{232} \mathrm{U}$ it contains would result in about a 100 to 1000 R radiation field it one foot distance. 


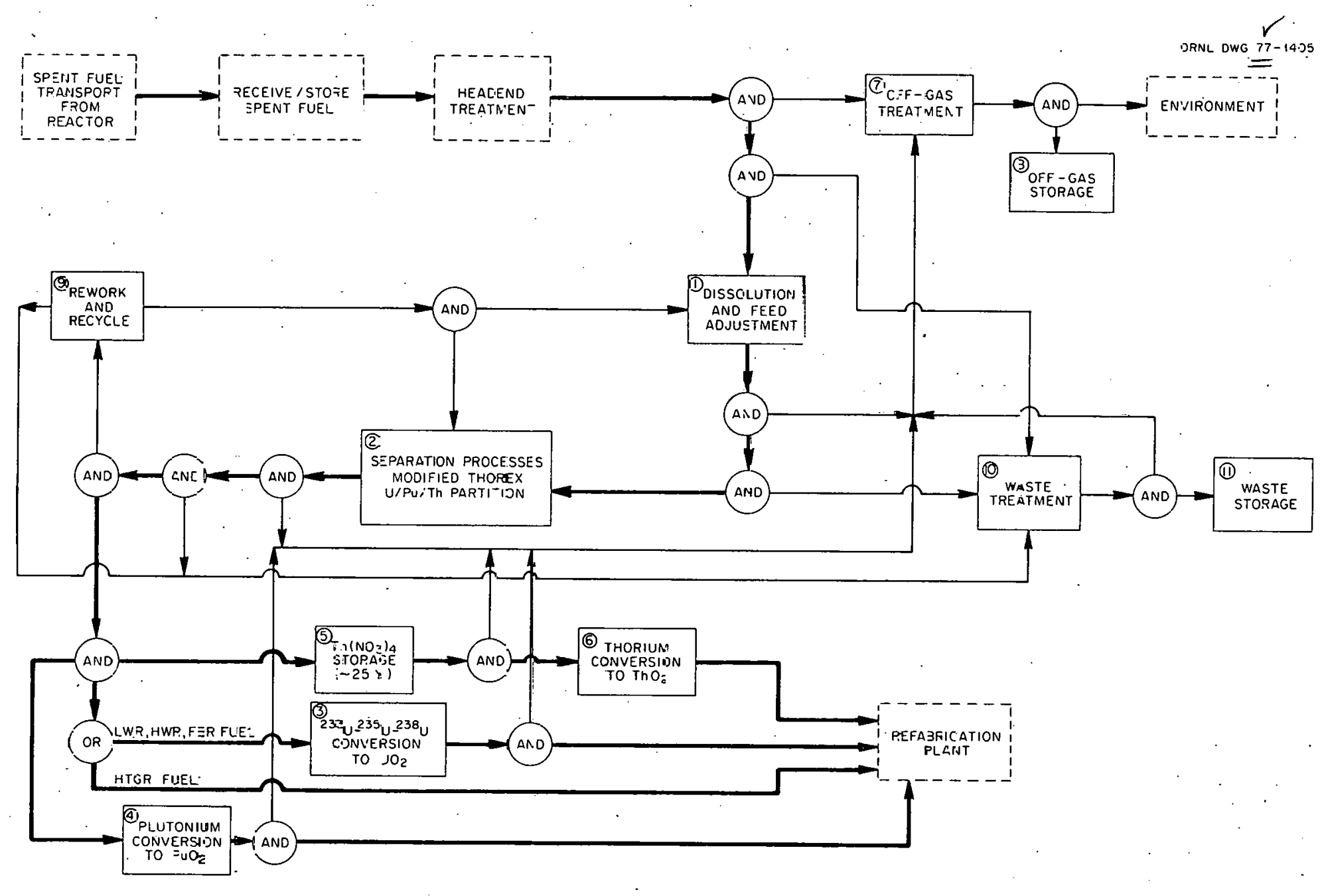

Fig. 4.1?. Reprocessing Scheme 10 - Leve1 1 Functional Flow Diagram: Reprocessing $\left({ }^{23} \mathrm{U},{ }^{35} \mathrm{U},{ }^{2} 8_{\mathrm{ij}}\right) \mathrm{O}_{2}-\mathrm{PuO}_{2}-\mathrm{ThO}_{2}$ and ${ }^{23}{ }^{3} \mathrm{UO}_{2}-\mathrm{PuO}_{2}-\mathrm{ThO}_{2}$ Fuel by the Modified Thorex Process. Partition of urazium, piutcnium, and thorium. 
Table 4.16. Analysis for Reprocessing Scheme 10 for $<15 \%$-Enriched ${ }^{23} U+{ }^{23} U$

Feed: $\quad 233,235,238 \mathrm{UO}_{2}\left(\mathrm{NO}_{3}\right)_{2}-\mathrm{Pu}\left(\mathrm{NO}_{3}\right)_{4}-\mathrm{Th}\left(\mathrm{NO}_{3}\right)_{4}$ $(<15 \% 233,235 \mathrm{U})$.

Products:

(1) $233,235,238 \mathrm{UO}_{2}(<15 \%, 233,235 \mathrm{U})$

(2) $\mathrm{PuO}_{2}$

(3) $\mathrm{ThO}_{2}$

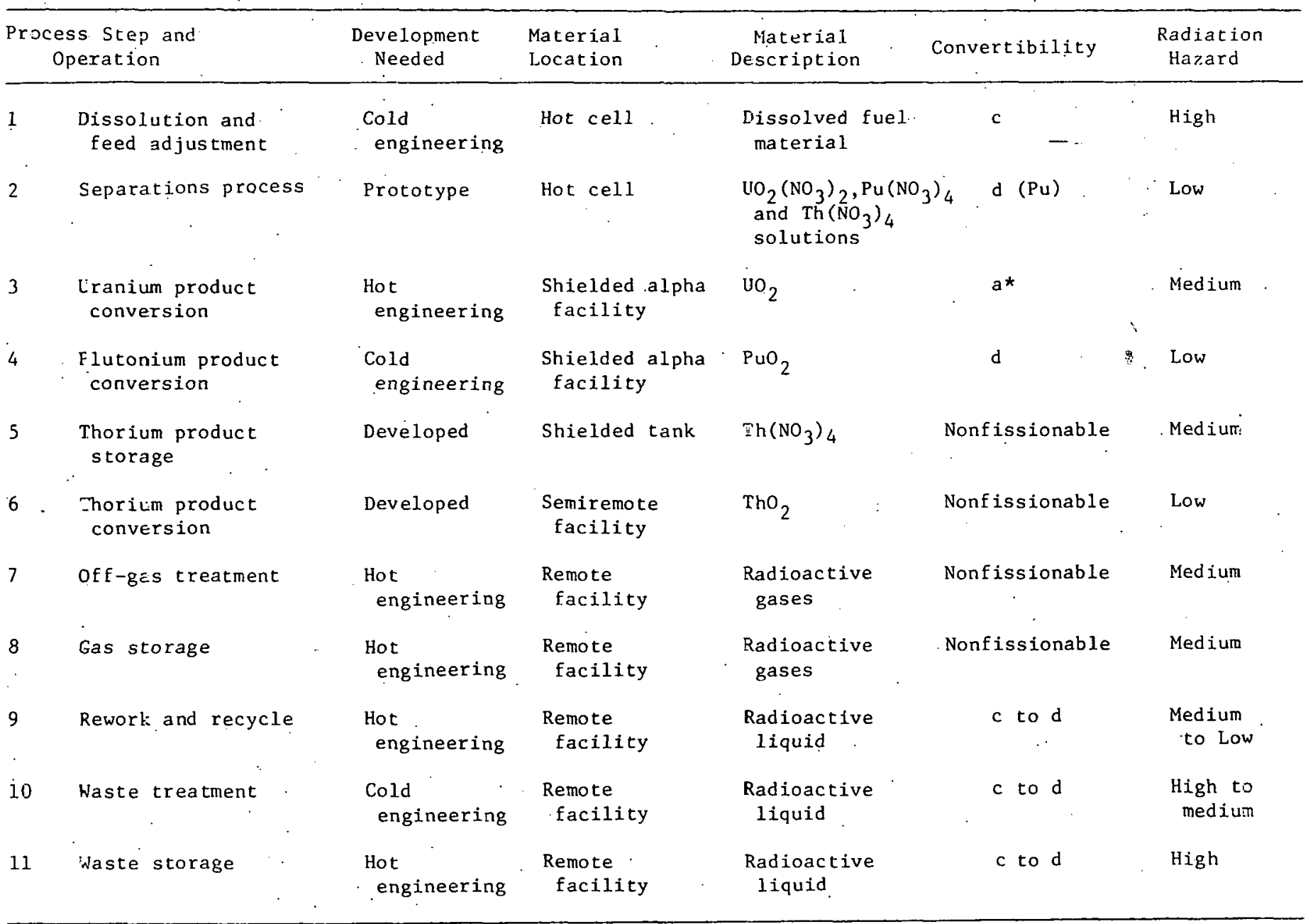

${ }^{*} 10 \mathrm{~kg}$ batch of ${ }^{233} \mathrm{U}$ in equilibrium with the daughter of the ${ }^{232} \mathrm{U}$ it contains would result in a 100 to $1000 \mathrm{R}$ radiation field at one foot distance. 
Table 4.17, Analysis for Reprocessing Scheme 10 三or $>15 \%$ - Inriched ${ }^{23} \mathrm{U}+{ }^{235} \mathrm{U}$

Feed: $\quad 233,235,23 \varepsilon_{\mathrm{UO}_{2}}\left(\mathrm{NO}_{3}\right)_{2}-\mathrm{Pu}\left(\mathrm{NO}_{3}\right)_{4}-\mathrm{Th}\left(\mathrm{NO}_{3}\right)$ $\left(>15 \%{ }^{23}, \tilde{\varepsilon} 35 \mathrm{U}\right)$

Prcducts: (1) $233,235,238 \mathrm{UO}_{2}(>15 \%, 233,235 \mathrm{U})$

(2) $\mathrm{PuO}_{2}$

(3) $\mathrm{ThO}_{2}$

\begin{tabular}{|c|c|c|c|c|c|c|}
\hline \multicolumn{2}{|c|}{$\begin{array}{c}\text { Process } S=e^{p} \text { ar.d } \\
\text { Operation }\end{array}$} & \multirow{2}{*}{$\begin{array}{c}\begin{array}{c}\text { Development } \\
\text { Needed }\end{array} \\
\text { Cold } .\end{array}$} & \multirow{2}{*}{$\begin{array}{l}\text { Material } \\
\text { Location } \\
\text { Hot cel }\end{array}$} & \multirow{2}{*}{$\begin{array}{c}\begin{array}{c}\text { Material } \\
\text { Description }\end{array} \\
\begin{array}{r}\text { Dissclived fuel } \\
\text { material }\end{array}\end{array}$} & Convertibility & \multirow{2}{*}{$\begin{array}{l}\text { Radiation } \\
\text { Hinzird }\end{array}$} \\
\hline J. & $\begin{array}{l}\text { Dissolutjon and } \\
\text { Feed adjustment }\end{array}$ & & & & c & \\
\hline 2 & Separaticns process & Prototype & Het cell & $\begin{array}{l}\mathrm{UO}_{2}\left(\mathrm{NO}_{3}\right)_{2}, \mathrm{Pu}(\mathrm{NO} \\
\left.\mathrm{Th}\left(\mathrm{NM}_{3}\right)_{4}\right)_{4} \text { sclut }\end{array}$ & $\begin{array}{l}3)_{4} d \\
\text { Lons }\end{array}$ & Low \\
\hline 3 & $\begin{array}{l}\text { Uranium } F=0 d d c t \\
\text { conversion }\end{array}$ & $\begin{array}{l}\text { Hot } \\
\text { engineering }\end{array}$ & $\begin{array}{l}\text { Srieifed alfoha } \\
\text { facility }\end{array}$ & $\mathrm{UO}_{2}$ & $\mathrm{~d}:$ & Med i um \\
\hline 4 & $\begin{array}{l}\text { Plutonium product } \\
\text { conversion }\end{array}$ & $\begin{array}{l}\text { Cold } \\
\text { engineering }\end{array}$ & $\begin{array}{l}\text { Shielled alfha } \\
\text { facility }\end{array}$ & $\mathrm{PuO}_{2}$ & d & Low \\
\hline 5 & $\begin{array}{l}\text { Thorium pirodist } \\
\text { storage }\end{array}$ & ['eveloped & Stiel Jec tark & $\begin{array}{l}\mathrm{Th}\left(\mathrm{NOO}_{3}\right)_{4} \\
\text { solurtion }\end{array}$ & Nonficsionable & Medium \\
\hline 6 & $\begin{array}{l}\text { Thorium prodiact } \\
\text { conversion }\end{array}$ & [eveloped & $\begin{array}{l}\text { Semir smcte- } \\
\text { facility }\end{array}$ & $\mathrm{ThO}_{2}$ & Nonfissionable & Low \\
\hline 7 & off-gas trea=ment & $\begin{array}{l}\text { Fot } \\
\text { engineeriris }\end{array}$ & $\begin{array}{l}\text { Remot? } \\
\text { facility }\end{array}$ & $\begin{array}{l}\text { Radiogctive } \\
\text { gases }\end{array}$ & Nonf issionable & Med ium \\
\hline 8 & Gas stozage & $\begin{array}{l}\text { Hot } \\
\text { engineering }\end{array}$ & $\begin{array}{l}\text { Remot } \geq \\
\text { facility }\end{array}$ & $\begin{array}{l}\text { Radijactive } \\
\text { gas } \equiv 3\end{array}$ & Nonfissionable & Medium \\
\hline 9 & Rework an: recycle & $\begin{array}{l}\text { Hot } \\
\text { engineering }\end{array}$ & $\begin{array}{l}\text { Remotz } \\
\text { facility }\end{array}$ & $\begin{array}{l}\text { Radijactive } \\
\text { liquid }\end{array}$ & c to d & $\begin{array}{l}\text { Medium } \\
\text { to low }\end{array}$ \\
\hline 10 & Waste tre $\equiv$ tment & $\begin{array}{l}\text { Cold } \\
\text { engineering }\end{array}$ & $\begin{array}{l}\text { Remote } \\
\text { facility }\end{array}$ & $\begin{array}{l}\text { Radiogctive } \\
\text { liquid. }\end{array}$ & c to d & $\begin{array}{l}\text { High to } \\
\text { medium }\end{array}$ \\
\hline 11 & Waste storage & $\begin{array}{l}\text { Hot } \\
\text { engineering }\end{array}$ & $\begin{array}{l}\text { Remote } \\
\text { facility }\end{array}$ & $\begin{array}{l}\text { Radiozctive } \\
\text { liquid }\end{array}$ & c & $\mathrm{High}$ \\
\hline
\end{tabular}

$*_{A} 10 \mathrm{~kg}$ batch of ${ }^{23} \mathrm{U}$ in equilibriun with the daughters of the ${ }^{232} \mathrm{U}$ it contains would result in a 100 to $1.000 \mathrm{R}$ radiatios $\mathrm{f}=\mathrm{eld}$ at one foot distance. 


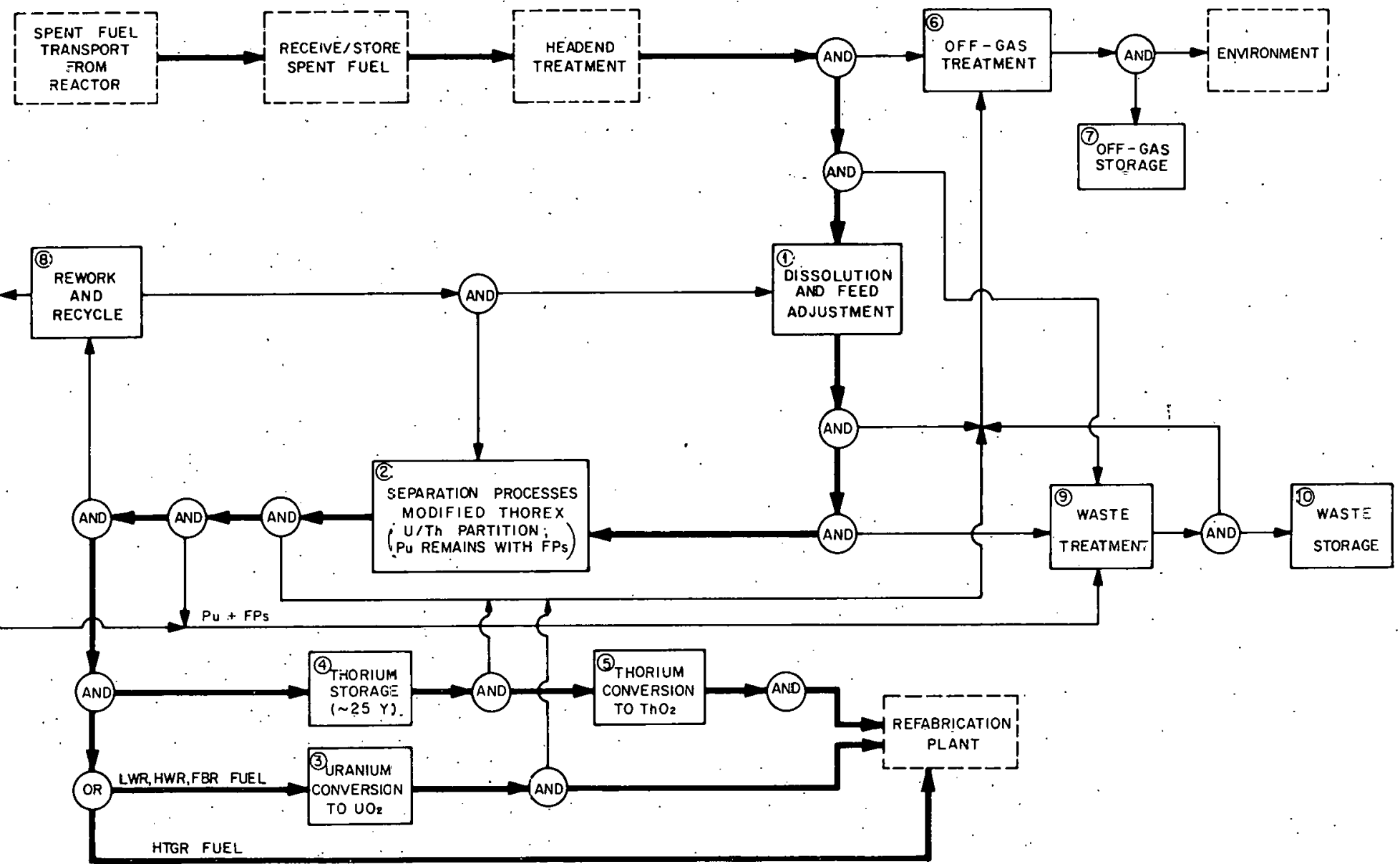

Fig. 4.18. Reprocessing Scheme 11 - Level 1 Functional Flow Diagram: Reprocessing $\left({ }^{3}{ }^{3} \mathrm{U},{ }^{3} \mathrm{~J} \mathrm{U},{ }^{3}{ }^{8} \mathrm{U}\right) \mathrm{O}_{2}-\mathrm{PuO}_{2}-\mathrm{ThO}_{2}$ Fuei or ${ }^{23}{ }^{3} \mathrm{UO}_{2}-\mathrm{PuO}_{2}-\mathrm{ThO}_{2}$ Fuel by the Modified Thorex Process. Partition of uranium and thorium. Plutonium stowaway with fission products. 
Table 4.18. Analysis for Reprocessing Saheme 11 for $<15 \%$-Enriched ${ }^{233} U+{ }^{235} U$
Feed:

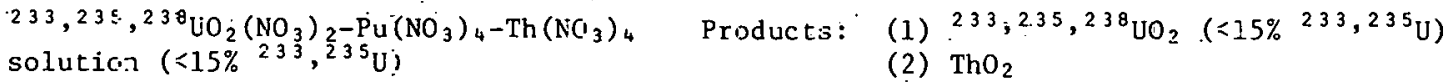

Pluton-un remains in the aqueoss phase with the fission products

\begin{tabular}{|c|c|c|c|c|c|c|c|}
\hline \multicolumn{2}{|c|}{$\begin{array}{c}\text { Process step and } \\
\text { Operation }\end{array}$} & \multirow{2}{*}{$\begin{array}{l}\begin{array}{c}\text { Development } \\
\text { Needed }\end{array} \\
\begin{array}{c}\text { Cold } \\
\text { engineerins }\end{array}\end{array}$} & \multirow{2}{*}{$\begin{array}{l}\text { Material } \\
\text { location }\end{array}$} & \multirow{2}{*}{$\begin{array}{c}\text { Material } \\
\text { Description } \\
\begin{array}{c}\text { Dissolvəd fuel } \\
\text { materi } \exists 1\end{array}\end{array}$} & Colvertibility & \multicolumn{2}{|l|}{$\begin{array}{l}\text { Radiation } \\
\text { Hazard }\end{array}$} \\
\hline 1 & $\begin{array}{l}\text { Dissolution and } \\
\text { feed ad-us tment }\end{array}$ & & & & c & $\mathrm{High}$ & \\
\hline 2 & Separatizns process & Frotctype & Hot cell & 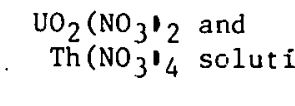 & ions & Mediumı & \\
\hline 3 & Uranium =onversion & $\begin{array}{l}\text { Hot } \\
\text { engineering }\end{array}$ & $\begin{array}{l}\text { Shielded alfha } \\
\text { facility }\end{array}$ & $\mathrm{UO}_{2}$ & a & Medium & \\
\hline 4 & $\begin{array}{l}\text { Thorium Jrociuct } \\
\text { storage }\end{array}$ & Developed & Shield „d tark & $\begin{array}{l}\mathrm{Th}\left(\mathrm{NO}_{3}\right)_{4} \\
\text { solution. }\end{array}$ & Nonfissionabie & Medium & . \\
\hline 5 & $\begin{array}{l}\text { Tharium product } \\
\text { canversion }\end{array}$ & Developed & $\begin{array}{l}\text { Semiremote } \\
\text { fanility }\end{array}$ & $\mathrm{ThO}_{2}$ & Nonfissionable & Low & \\
\hline 6 & off-gas =reatment & $\begin{array}{l}\text { Hot } \\
\text { engineering }\end{array}$ & $\begin{array}{l}\text { Remate } \\
\text { facility }\end{array}$ & $\begin{array}{l}\text { Radioactive } \\
\text { gases }\end{array}$ & Nonfissionable & Medium & \\
\hline 7 & Gas storaze & $\begin{array}{l}\mathrm{H} \supset \mathrm{t} \\
\quad \text { əngineering }\end{array}$ & $\begin{array}{l}\text { Remote } \\
\text { facil } 1 \text { ty }\end{array}$ & $\begin{array}{l}\text { Radioactive } \\
\text { gases }\end{array}$ & Nonf issionable & Medium & \\
\hline 8 & Rework and recycle & $\begin{array}{l}\text { Hot } \\
\text { əngineering }\end{array}$ & $\begin{array}{l}\text { Remote } \\
\text { facility }\end{array}$ & $\begin{array}{l}\text { Radioactive } \\
\text { liquid }\end{array}$ & c to $d$ & $\begin{array}{l}\text { Medium } \\
\text { to low }\end{array}$ & \\
\hline 9 & Waste treatment & $\begin{array}{l}\text { Cold } \\
\text { engineering }\end{array}$ & $\begin{array}{l}\text { Femote } \\
\text { facility }\end{array}$ & $\begin{array}{l}\text { Radioactive } \\
\text { liquid }\end{array}$ & $c$ to d $(P, u)$ & $\begin{array}{l}\text { High to } \\
\text { low }\end{array}$ & \\
\hline 10 & Waste stc rag? & $\begin{array}{l}\text { Hot } \\
\text { engineering }\end{array}$ & $\begin{array}{l}\text { Semote } \\
\text { facility }\end{array}$ & $\begin{array}{l}\text { Radioactive } \\
\text { liquid }\end{array}$ & c & High & \\
\hline
\end{tabular}

* With rela-ivaly simple changes in the separations process flowsheet the plutonium could be recovered. 
Table 4.19. Analysis for Reprocessing Scheme 11 for $>15 \%$-Enriched ${ }^{233} \mathrm{U}+{ }^{235} \mathrm{U}$

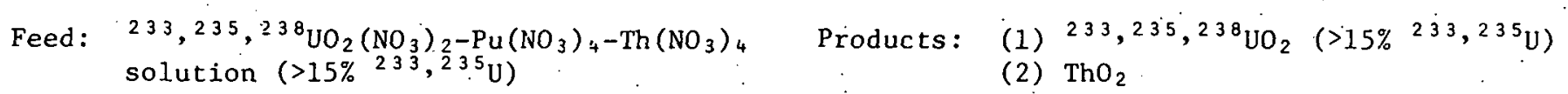

Plutonium remains in the aqueous phase with the fission products

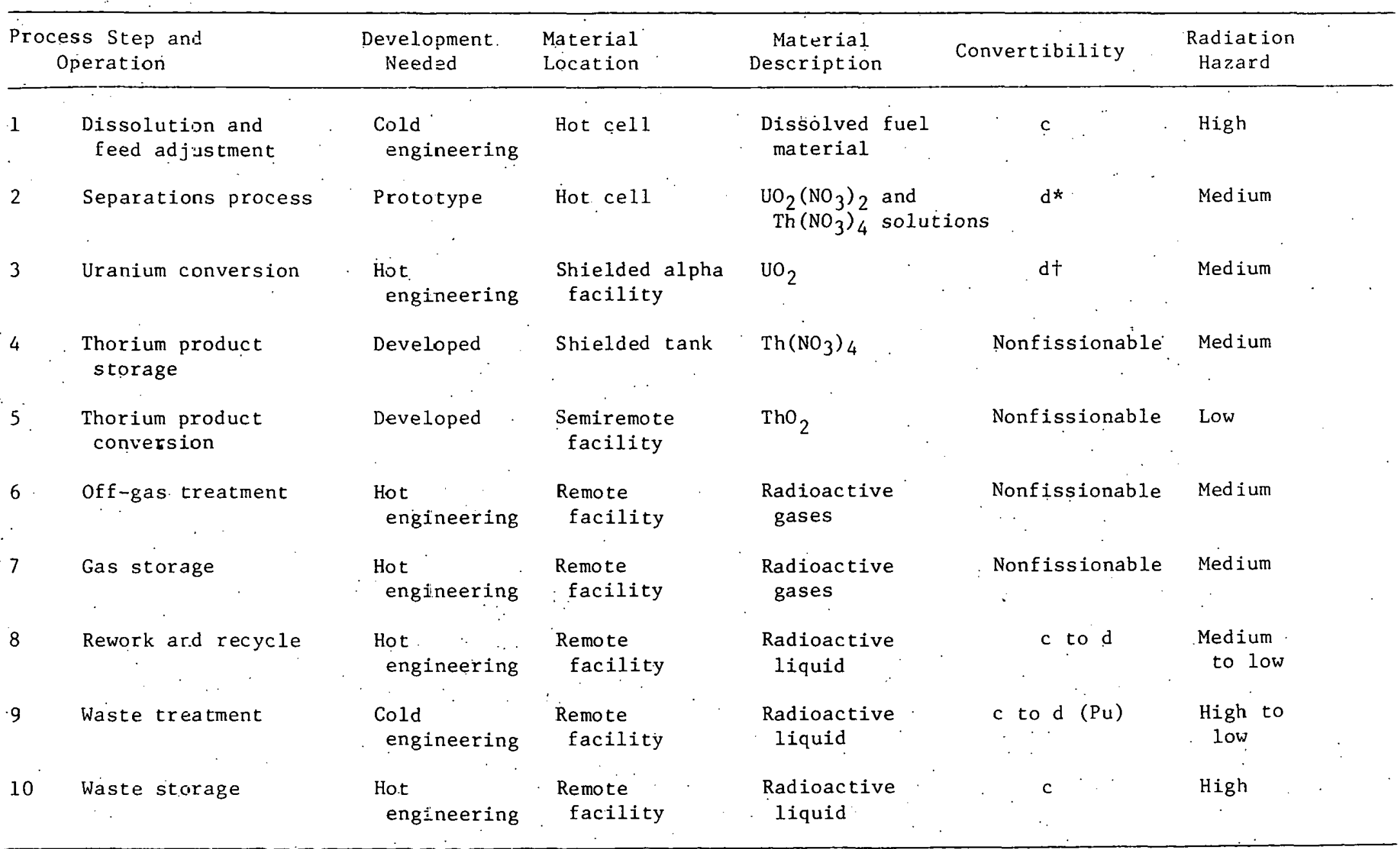

*With relctively simple changes in the separations process flowsheet the plutionium could be recovered.

tA $10 \mathrm{~kg}$ tatch of ${ }^{23}{ }^{3} \mathrm{U}$ in equilibrium with the daughters of the ${ }^{232} \mathrm{U}$ it contains would result in a 100 . to $1000 \mathrm{R}$ radiation field at one foot distance. 


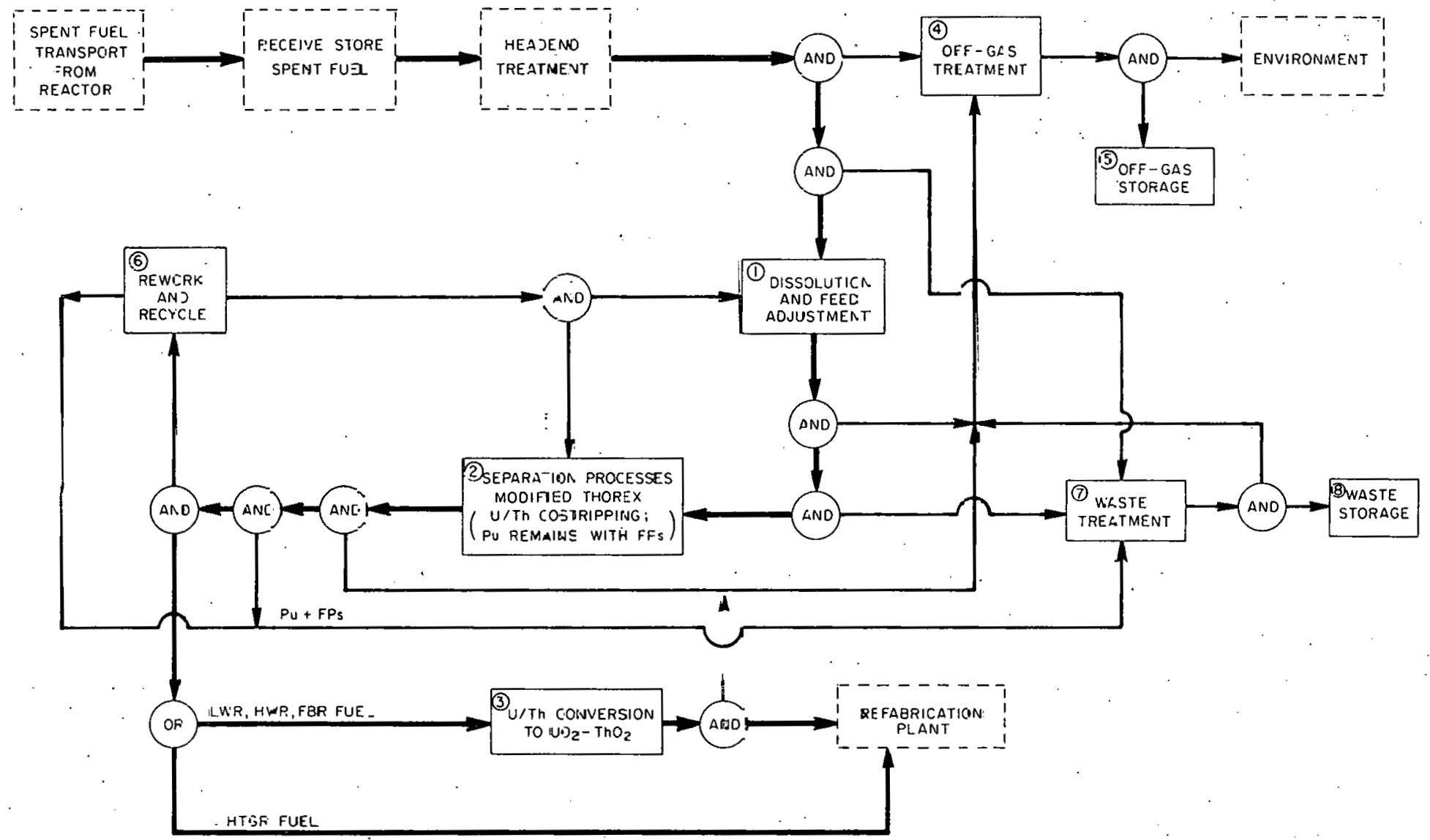

Fig. 4.19. Reprocessing Scheme 12 - Level 1 Functional Flow Diagram: Reprocessing $\left({ }^{23} \mathrm{U},{ }^{35} \mathrm{U},{ }^{238} \mathrm{U}^{3} \mathrm{O}_{2}-\mathrm{PuO}_{2}-\mathrm{ThO}_{2}\right.$ Fuel $\mathrm{Dr}{ }^{233} \mathrm{DO}_{2}-\mathrm{Pu}_{2}-\mathrm{ThO}_{2}$ Fuel by the Modified Thorex Process. Costripping of Uranium and Thorium. Plutönium stowaway with fission procucts. 
Table 4.20. Analysis for Reprocessing Scheme 12 for $<15 \%$-Enriched ${ }^{233} \mathrm{U}+{ }^{235} \mathrm{U}$

Feed: $\quad 233,235,238 \mathrm{UO}_{2}\left(\mathrm{NO}_{3}\right)_{2}-\mathrm{Pu}\left(\mathrm{NO}_{3}\right)_{4}-\mathrm{Th}\left(\mathrm{NO}_{3}\right)_{4}$ solution Product: (1) $233,235,238 \mathrm{UO}_{2}-\mathrm{ThO}_{2}\left(<15 \%{ }^{233,235} \mathrm{U}\right)$

$(<15 \% 233,235 \mathrm{U}) \quad \because \quad$ Plutonium remains with fission products in aqueous waste

\begin{tabular}{|c|c|c|c|c|c|c|c|}
\hline & $\begin{array}{l}\text { Ss Step and } \\
\text { peration. }\end{array}$ & $\begin{array}{l}\text { Development } \\
\text { Needed }\end{array}$ & $\begin{array}{l}\text { Material } \\
\text { Location }\end{array}$ & $\begin{array}{c}\text { Material } \\
\text { Description }\end{array}$ & onvertibility & $\begin{array}{l}\text { Radiation } \\
\text { Hazard }\end{array}$ & \\
\hline 1 & $\begin{array}{l}\text { Dissolution and } \\
\text { feed adjustment }\end{array}$ & $\begin{array}{l}\text { Colc } \\
\text { engineering }\end{array}$ & Hot cell & $\begin{array}{l}\text { Dissolved fuel } \\
\text { material }\end{array}$ & c & High. & \\
\hline 2 & Separations process & Prototype & Hot cell & $\begin{array}{l}\mathrm{UO}_{2}\left(\mathrm{NO}_{3}\right)_{2}-\mathrm{Th}\left(\mathrm{NO}_{3}\right)_{4} \\
\text { solution }\end{array}$ & $a *$ & Medium & \\
\hline 3 & Product conversion & $\begin{array}{l}\text { Hot } \\
\text { engineering }\end{array}$ & $\begin{array}{l}\text { Shielded alpha } \\
\text { facility }\end{array}$ & $\mathrm{UO}_{2}-\mathrm{ThO}_{2}$ & $\vdots$ & Medium & \\
\hline 4 & Of $\mathrm{f}$-gas trea:ment & $\begin{array}{l}\text { Hot } \\
\text { engineering }\end{array}$ & $\begin{array}{l}\text { Remote } \\
\text { facility }\end{array}$ & $\begin{array}{l}\text { Radiaoctive } \\
\text { gases }\end{array}$ & Nonfissionable & Medium & \\
\hline 5 & Gas storage & $\begin{array}{l}\text { Hot } \\
\text { engineering }\end{array}$ & $\begin{array}{l}\text { Remote } \\
\text { facility }\end{array}$ & $\begin{array}{l}\text { Radioactive } \\
\text { gases }\end{array}$ & Nonfissionable & Medium . & \\
\hline 6 & Rework and recycle & $\begin{array}{l}\text { Hot } \\
\text { engineering }\end{array}$ & $\begin{array}{l}\text { Remote } \\
\text { facility }\end{array}$ & $\begin{array}{l}\text { Radioactive } \\
\text { liquid }\end{array}$ & $c$ to $d(\mathrm{Pu})$ & $\begin{array}{l}\text { Medium } \\
\text { to low }\end{array}$ & \\
\hline 7 & Waste treatment & $\begin{array}{l}\text { Cold } \\
\text { engineering }\end{array}$ & $\begin{array}{l}\text { Remote } \\
\text { facility }\end{array}$ & $\begin{array}{l}\text { Radioactive } \\
\text { liquid }\end{array}$ & c to $d(P u)$ & $\begin{array}{l}\text { High to } \\
\text { medium }\end{array}$ & \\
\hline 8 & Waste storage & $\begin{array}{l}\text { Hot } \\
\text { engineering }\end{array}$ & $\begin{array}{l}\text { Remote } \\
\text { facility. }\end{array}$ & $\begin{array}{l}\text { Radioactive } \\
\text { liquid }\end{array}$ & c & High & \\
\hline
\end{tabular}

*The plutonium could be recovered with the uranium and thorium by use of relatively simple process changes. 
Table 4.21. Analysis for Reprocessing Scheme 12 for $>15 \%$-Enriched ${ }^{23}{ }^{3} \mathrm{U}+{ }^{235} \mathrm{U}$

\begin{tabular}{|c|c|c|c|c|c|c|}
\hline \multicolumn{2}{|c|}{$\begin{array}{c}\text { Process Step and } \\
\text { Operation }\end{array}$} & \multirow{2}{*}{$\begin{array}{l}\begin{array}{l}\text { Development } \\
\text { Needed }\end{array} \\
\begin{array}{c}\text { Eold } \\
\text { engineering }\end{array}\end{array}$} & \multirow{2}{*}{$\begin{array}{l}\text { Material } \\
\text { Location }\end{array}$} & \multirow{2}{*}{$\begin{array}{c}\begin{array}{c}\text { Material } \\
\text { Descriftion }\end{array} \\
\begin{array}{c}\text { Dissolved fuel } \\
\text { material }\end{array}\end{array}$} & Convertibility & \multirow{2}{*}{$\begin{array}{c}\begin{array}{c}\text { Radiation } \\
\text { Hazard }\end{array} \\
\text { High }\end{array}$} \\
\hline 1 & $\begin{array}{l}\text { Dissolution a-d } \\
\text { feed adjustm } \cong n t\end{array}$ & & & & $\therefore$ & \\
\hline 2 & Sefarations process & Prototyp & Hot cell & $\begin{array}{l}\left.\mathrm{UO}_{2}\left(\mathrm{NO}_{3}\right) 2_{2}-\mathrm{Th}: \mathrm{HO}_{\xi}\right)_{4} \\
\text { solution }\end{array}$ & $c *$ & Medium \\
\hline 3 & Prcduce conversior & Cold & $\begin{array}{l}\text { Siieldet alfha } \\
\text { facility }\end{array}$ & $\mathrm{UO}_{2}-\mathrm{ThO}_{2}$ & $\therefore$ & Medium \\
\hline 4 & off-gas treatmen: & $\begin{array}{l}\text { 弚 } \\
\text { engineering }\end{array}$ & $\begin{array}{l}\text { Remote } \\
\text { facility }\end{array}$ & $\begin{array}{l}\text { Radicective } \\
\text { gases }\end{array}$ & Nonfissionable & Medium \\
\hline 5 & Gas storage & $\begin{array}{l}\text { Hot } \\
\text { engineezing }\end{array}$ & $\begin{array}{l}\text { Remote } \\
\text { facility }\end{array}$ & $\begin{array}{l}\text { Radioactive } \\
\text { gases: }\end{array}$ & Nonfissionable. & Medium \\
\hline 6 & Rework and reicycle & $\begin{array}{l}\text { Hot } \\
\text { enginee:ing }\end{array}$ & $\begin{array}{l}\text { Rミmote } \\
\text { facility }\end{array}$ & $\begin{array}{l}\text { Radioactive } \\
\text { liquid }\end{array}$ & c tc d (Pu) & $\begin{array}{l}\text { Medium } \\
\text { to low }\end{array}$ \\
\hline 7 & Waste treatment & $\begin{array}{l}\text { Cold } \\
\text { enginee-ing }\end{array}$ & $\begin{array}{l}\text { Remote } \\
\text { Eacility }\end{array}$ & $\begin{array}{l}\text { Radioactive } \\
\text { liquid }\end{array}$ & c to $d(\mathrm{Pu})$ & $\begin{array}{l}\text { High to } \\
\text { medium }\end{array}$ \\
\hline 8 & Wasce storage & $\begin{array}{l}\text { Hot } \\
\text { enginee=ing }\end{array}$ & $\begin{array}{l}\text { Remote } \\
\text { Eacili }=y\end{array}$ & $\begin{array}{l}\text { Radioactive } \\
\text { liquid }\end{array}$ & $c$ & $\mathrm{High}$ \\
\hline
\end{tabular}

*The plutonium coold be recovered with the uranium and thorium by use cf relatively simple process changes.

TA $10 \mathrm{~kg}$ batch of ${ }^{23} \mathrm{U}$.in equilibrium with the daughters of the ${ }^{232} \mathrm{U}$ it contains would result in a 100 to $1000 R$ radiation field at ore foot distance. 
ORNL OWG 77.1403

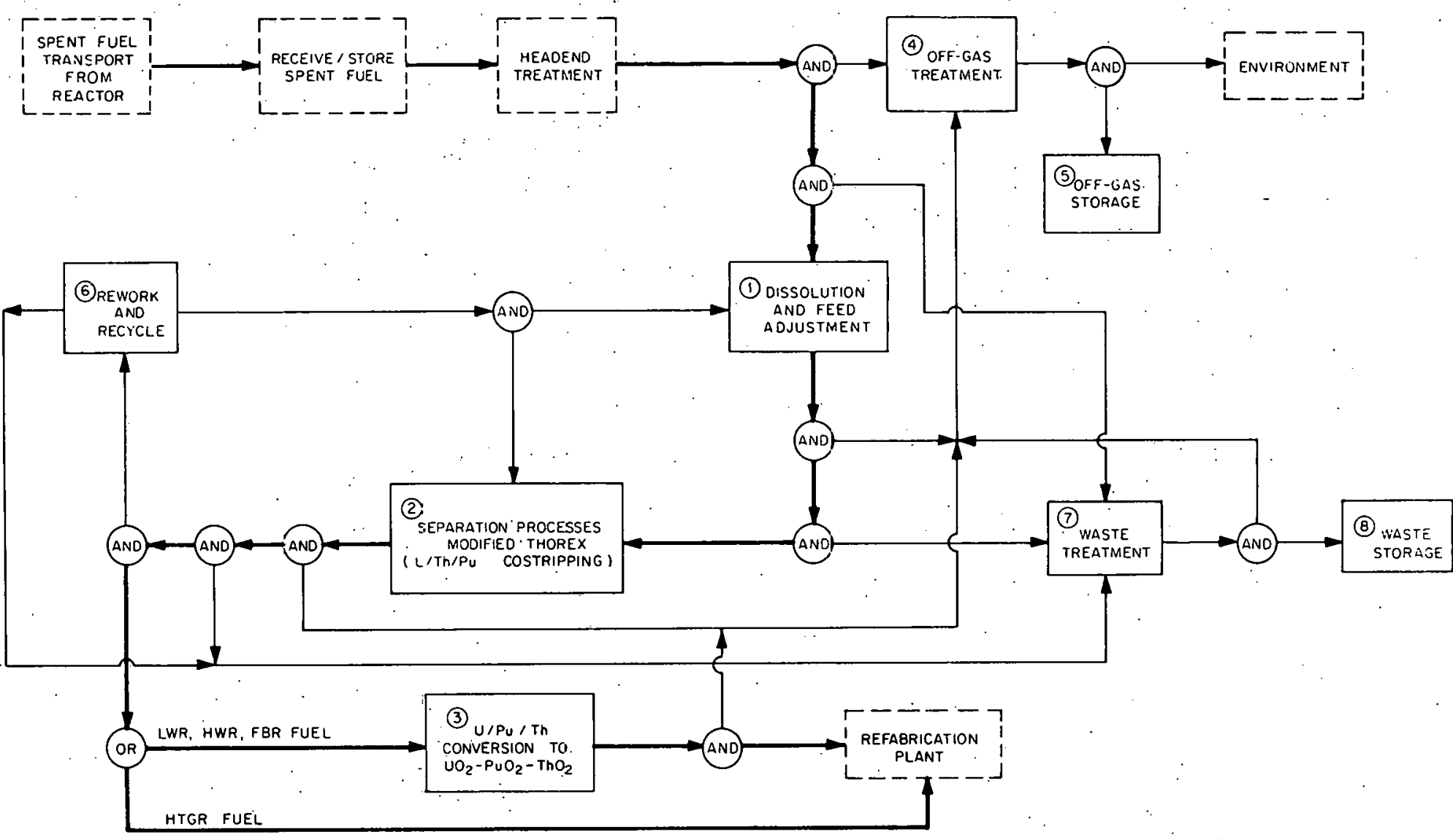

(233ig. 4.20. Reprocessing Scheme 13 - Level 1 Functional Flow Diagram: Reprocessing Costripping of Uranium, Plutonium, and Thorium. 
Table 4.22. Analysis for Reprocessing Scheme 13 for $<15 \%$ Enriched ${ }^{233} U+{ }^{235} U$

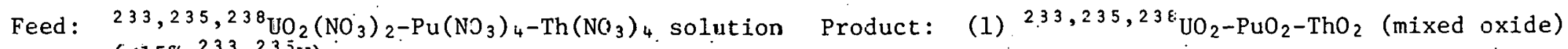
$(<15 \% 233,23.5 \mathrm{U})$

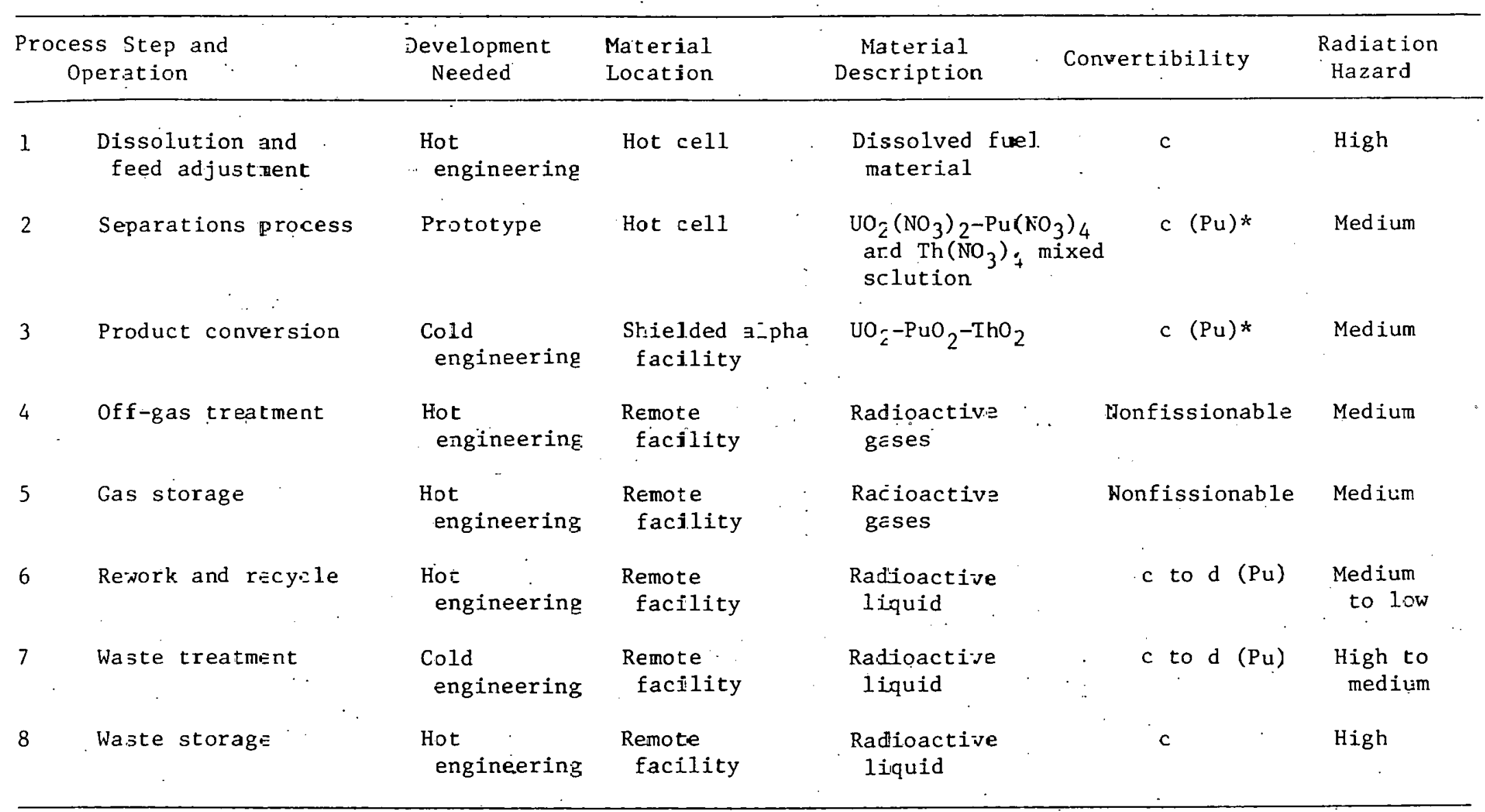


Table 4.23. Analysis for Reprocessing Scheme 13 for $>15 \%$-Enriched $233,235 \mathrm{U}$

Feed: $\begin{aligned} & 233,235,238 \mathrm{UO}_{2}\left(\mathrm{NO}_{3}\right)_{2}-\mathrm{Pu}\left(\mathrm{NO}_{3}\right)_{4}-\mathrm{Th}\left(\mathrm{NO}_{3}\right)_{4} \text { solution Product: (1) } 233,235,238 \mathrm{UO}_{2}-\mathrm{PuO}_{2} \text {-ThO } 2 \text { (mixed oxides) } \\ & (>15 \%, 233,235 \mathrm{U})\end{aligned}$

\begin{tabular}{|c|c|c|c|c|c|c|}
\hline \multicolumn{2}{|c|}{$\begin{array}{c}\text { Frocess Step and } \\
\text { Operation }\end{array}$} & \multirow{2}{*}{$\begin{array}{l}\begin{array}{c}\text { Development } \\
\text { Neaded }\end{array} \\
\begin{array}{l}\text { Cold } \\
\text { enjineering }\end{array}\end{array}$} & \multirow{2}{*}{$\begin{array}{l}\text { Material } \\
\text { Location } \\
\text { Hot cell. }\end{array}$} & \multirow{2}{*}{$\begin{array}{c}\text { Material } \\
\text { Description } \\
\begin{array}{c}\text { Dissolved fuel } \\
\text { material }\end{array}\end{array}$} & Convertibility & \multirow{2}{*}{$\begin{array}{c}\begin{array}{c}\text { Radiation } \\
\text { Hazard }\end{array} \\
\cdot \text { High }\end{array}$} \\
\hline 1. & $\begin{array}{l}\text { Dissolution and } \\
\text { feed adjustment }\end{array}$ & & & & c & \\
\hline 2 & Separations process & Prototype & Hot cell & $\begin{array}{l}\mathrm{UO}_{2}\left(\mathrm{NO}_{3}\right)_{2}-\mathrm{Pu}\left(\mathrm{NO}_{3}\right)_{4-}- \\
\mathrm{Th}\left(\mathrm{NO}_{3}\right)_{4} \text { mixed } \\
\text { solutions }\end{array}$ & $c(\mathrm{Pu}) *$ & Medium \\
\hline 3 & Product conversion & $\begin{array}{l}\text { Colft } \\
\text { lajoratory }\end{array}$ & $\begin{array}{l}\text { Shielded alpha } \\
\text { facility }\end{array}$ & $\mathrm{UO}_{2}-\mathrm{PuO}_{2}-\mathrm{ThO}_{2}$ & $c(\mathrm{Pu}) *$ & Medium \\
\hline 4 & Off-gas treatment & $\begin{array}{l}\text { Hot } \\
\text { engineering }\end{array}$ & $\begin{array}{l}\text { Remote } \\
\text { facility }\end{array}$ & $\begin{array}{l}\text { Radioactive } \\
\text { gases }\end{array}$ & Nonfissionable & Medium \\
\hline 5 & Gas storage & $\begin{array}{l}\text { Hot } \\
\text { enzineering. }\end{array}$ & $\begin{array}{l}\text { Remote } \\
\text { facility. }\end{array}$ & $\begin{array}{l}\text { Radioactive } \\
\text { gases }\end{array}$ & Nonfissionable & Med ium \\
\hline 6 & Rework and recycle & $\begin{array}{l}\text { Hot } \\
\text { engineering }\end{array}$ & $\begin{array}{l}\text { Remote } \\
\text { facility }\end{array}$ & $\begin{array}{l}\text { Radioactive } \\
\text { liquid }\end{array}$ & c to d & $\begin{array}{l}\text { Medium } \\
\text { to low }\end{array}$ \\
\hline 7 & Waste treatment & $\begin{array}{l}\text { Cold } \\
\text { engineering }\end{array}$ & $\begin{array}{l}\text { Remote } \\
\text { facility }\end{array}$ & $\begin{array}{l}\text { Radioactive } \\
\text { liquid }\end{array}$ & $c$ to $d$ & $\begin{array}{l}\text { High to } \\
\text { medium }\end{array}$ \\
\hline 8 & Waste storage & $\begin{array}{l}\text { Hot } \\
\text { engineering }\end{array}$ & $\begin{array}{l}\text { Remote } \\
\text { facility }\end{array}$ & $\begin{array}{l}\text { Radioactive } \\
\text { liquid }\end{array}$ & c & $\mathrm{High}$ \\
\hline
\end{tabular}

*The plutonium could be separated from the other components by use of relatively simple process changes. 
ORNL OWG $77-1402$

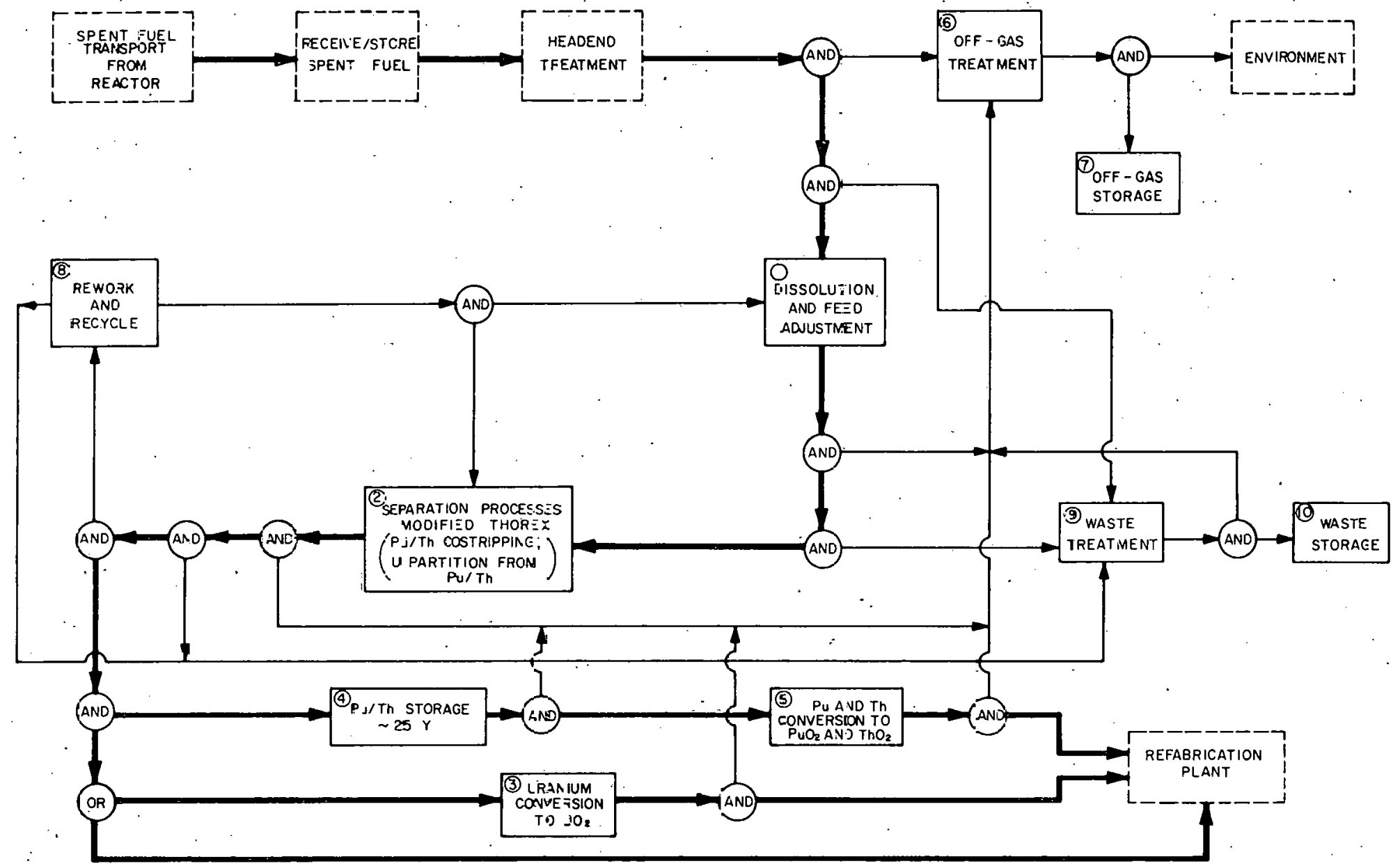

Fig. 4.21. Reprocessing Scheme -4 - Level 1 Functional Flow Diagram: Reprocessing $\left({ }^{2} 3{ }^{3} \mathrm{U},{ }^{3} \mathrm{U},{ }^{2}{ }^{8} \mathrm{U}\right) \mathrm{O}_{2}-\mathrm{PuO}_{\overline{4}}-\mathrm{ThO}_{2}$ Fuel and ${ }^{23}{ }^{3} \mathrm{UO}_{2}-\mathrm{PuO}_{2}-\mathrm{TH}_{2}$. Fuel by the Modified Thorex Process. Costripping of plutonium and thorium. Partition of uranium from plutonium-thorium mixture. 
Table 4.24. Analys-s for Reprocessing Scheme 14 for $<15 \%$-Enriched ${ }^{23}{ }^{3} U+{ }^{235} U$

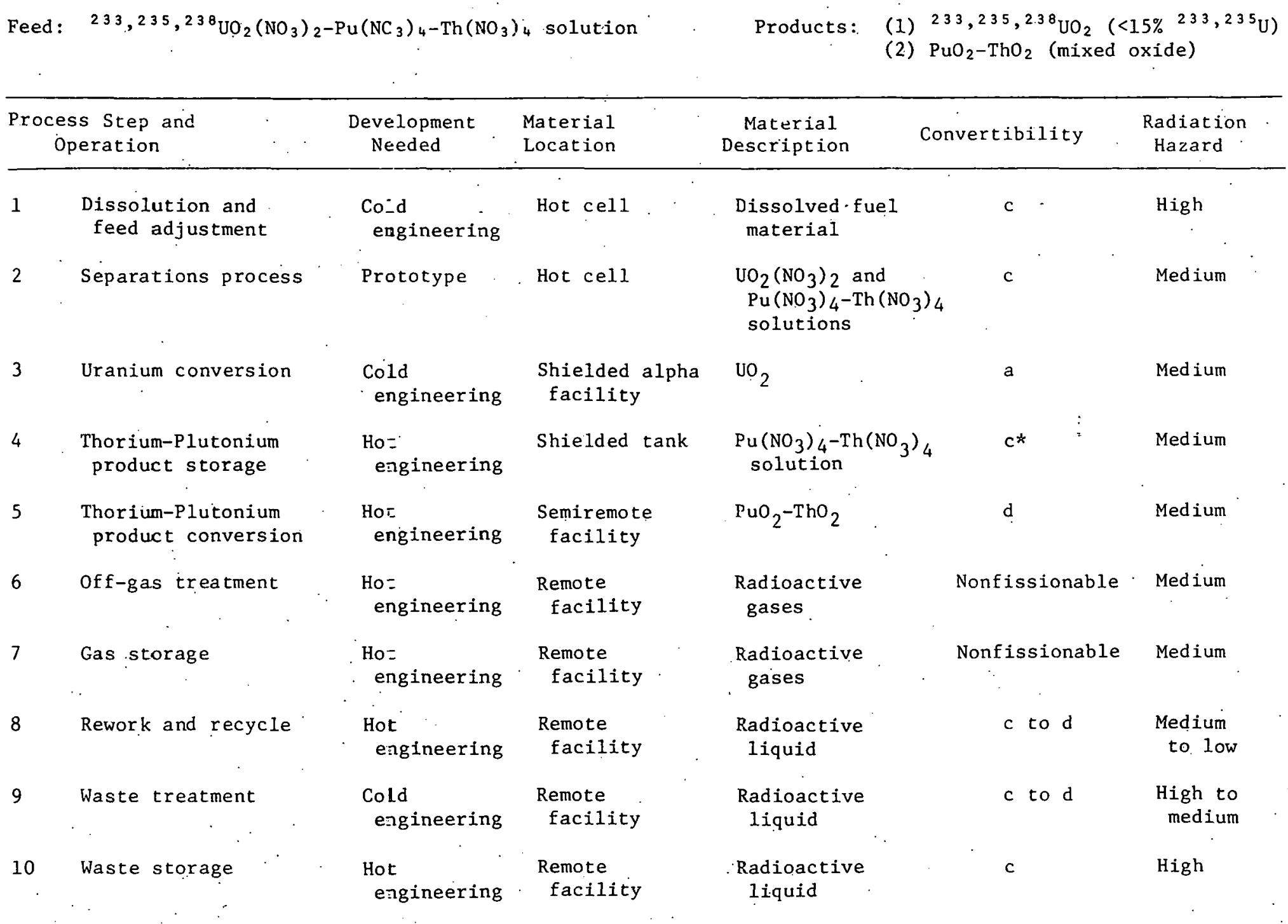

*The plutonium could be separated from the thorium by use of relatively simple process changes. 
Table 4.25. Analysis for Reprocessing Scheme 14 for $>15 \%$ Enriched ${ }^{233} \mathrm{U}+{ }^{235} \mathrm{U}$ Feed: $233,235,238 \mathrm{UO}_{2}\left(\mathrm{NO}_{3}\right)_{2}-\mathrm{Pu}\left(\mathrm{NO}_{3}\right)_{4}-\mathrm{Th}\left(\mathrm{HO}_{3}\right)_{4}$ solution

Product: $(1) 233,235,238 \mathrm{UO}_{2}\left(>15 \%{ }^{233,235} \mathrm{U}\right)$

(2) $\mathrm{PuO}_{2}-\mathrm{ThO}_{2}$ (mixed oxide)

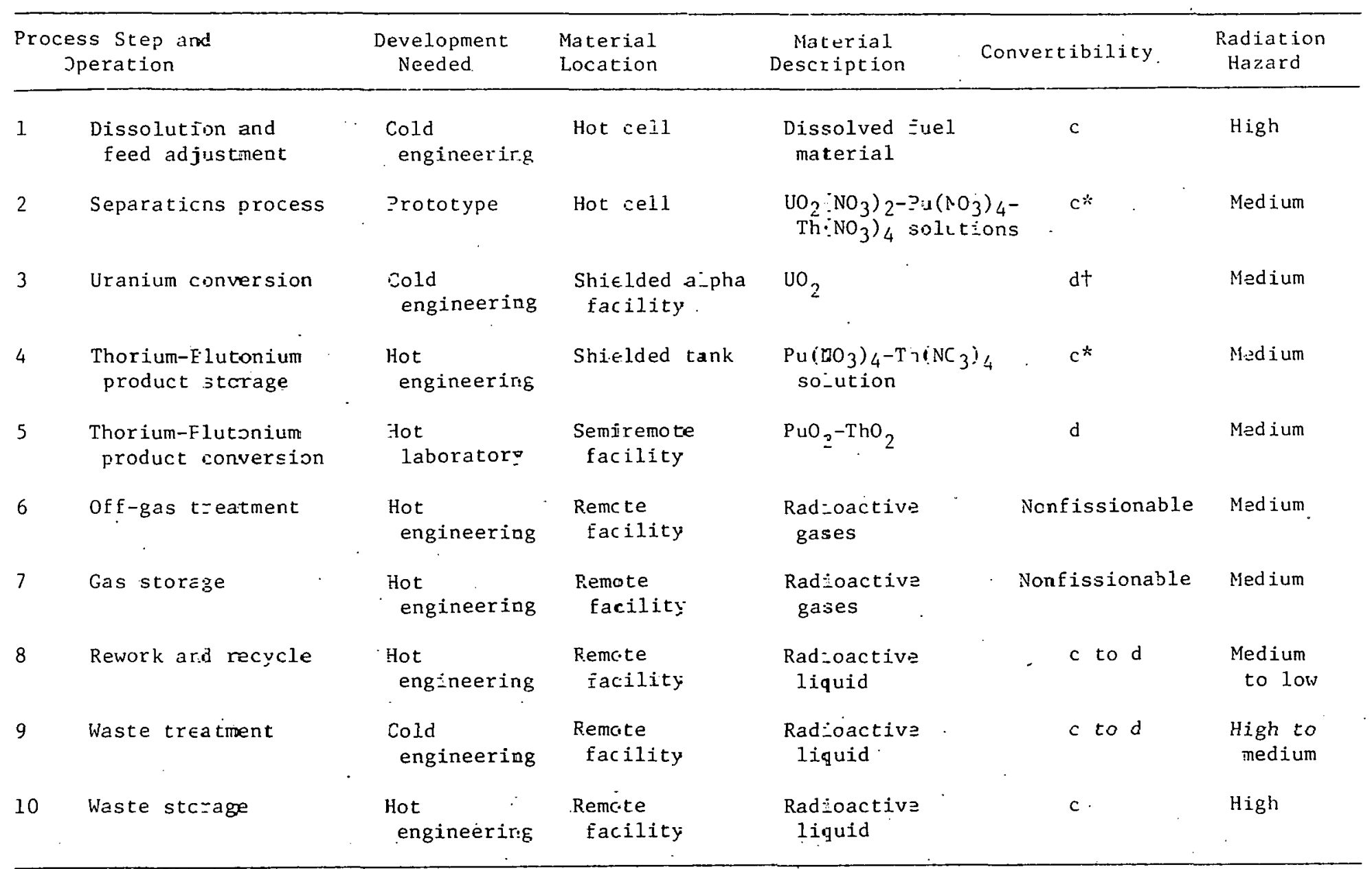

*The plutonitm could te separated fron the chorium by use of relativelo simple process changes.

tA $10 \mathrm{~kg}$ batch of ${ }^{233} \mathrm{U}$ in equilibrium with the ${ }^{2: 2 \cdot \mathrm{J}}$ it contains would zesult in a. 100 to $1000 \mathrm{R}$ radiation field at one foot distance. 


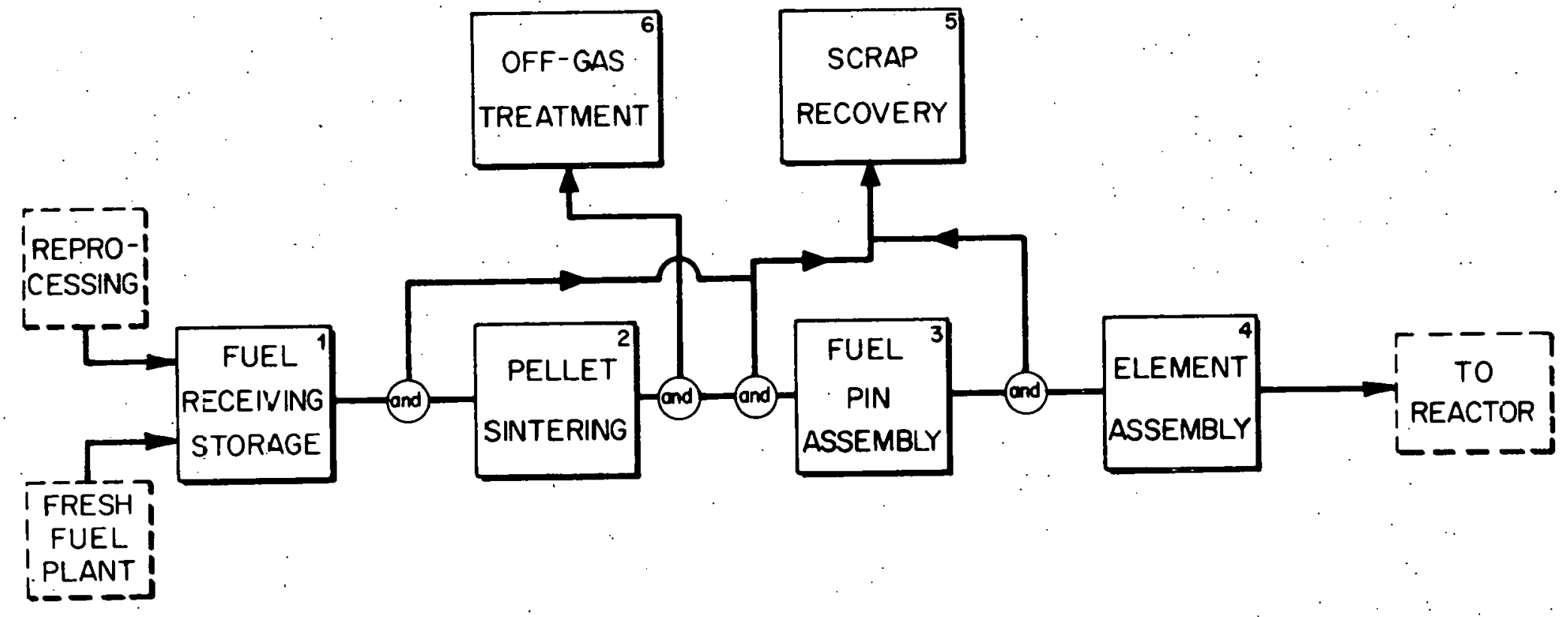

Fig. 4.22. Diagram 1, Leve1 1 Functional Flow Diagram: LWR-HWR-FBR Fuel Element Fabrication. 
Table 4.26. Analysis of Elel Refabrication Method 1, F1ow Diagram 1

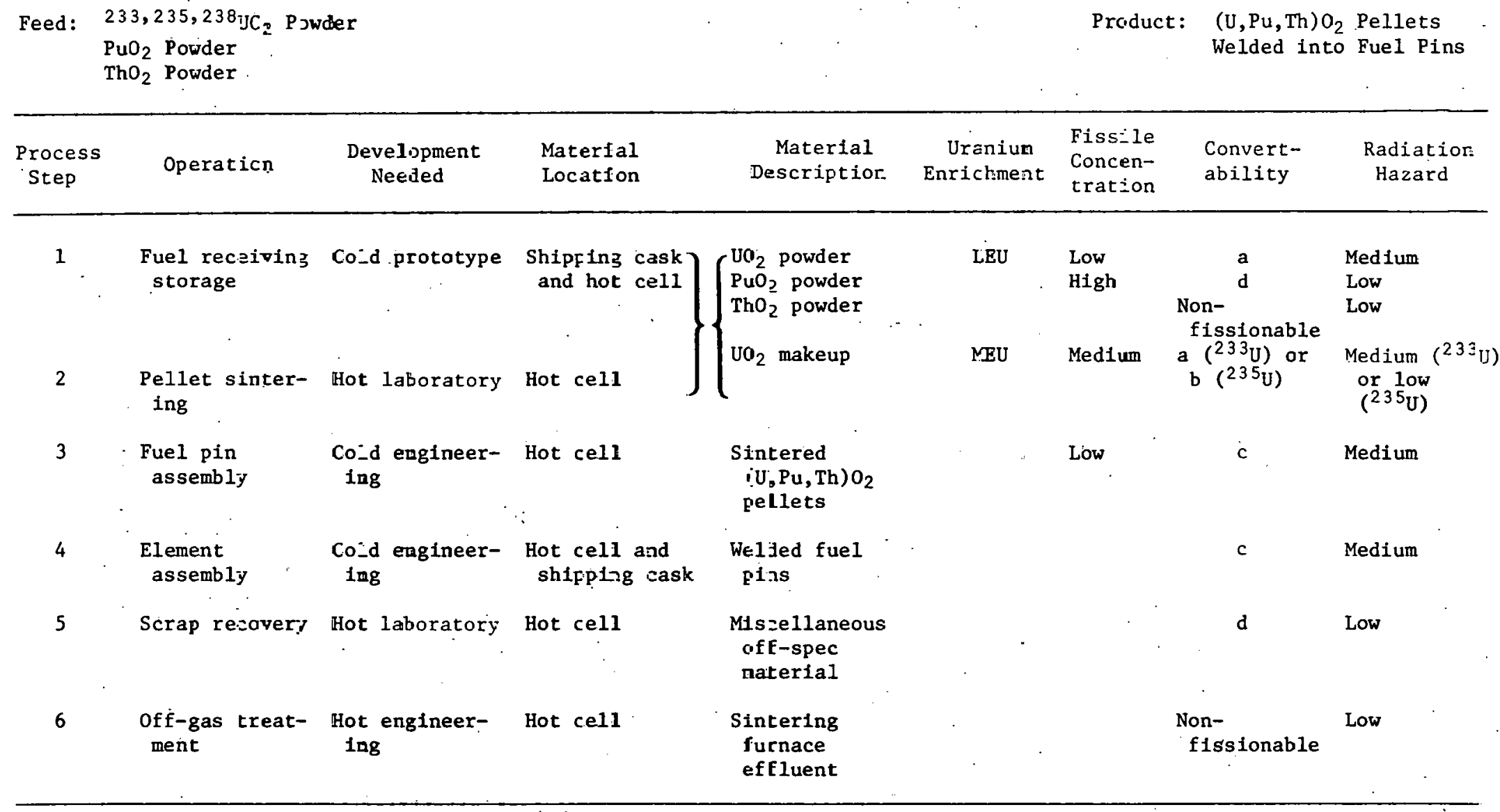


Table 4.27. Analysis of Fuel Refabrication Method 2, Flow Diagram 1

Feed: Mixed 0xides of and $T h$
Product: Sintered Pellets of

(U, $\mathrm{Pu}, \mathrm{Th}) \mathrm{O}_{2}$ Welded into Fuel Pins

\begin{tabular}{|c|c|c|c|c|c|c|c|c|}
\hline $\begin{array}{l}\text { Process } \\
\text { Step }\end{array}$ & Operation & $\begin{array}{l}\text { Development } \\
\text { Needed }\end{array}$ & $\begin{array}{l}\text { Material } \\
\text { Location }\end{array}$ & $\begin{array}{c}\text { Material } \\
\text { Description }\end{array}$ & $\begin{array}{c}\text { Uranium } \\
\text { Enrichment }\end{array}$ & $\begin{array}{l}\text { Fissile } \\
\text { Concen- } \\
\text { tration }\end{array}$ & $\begin{array}{l}\text { Convert- } \\
\text { ability }\end{array}$ & $\begin{array}{l}\text { Radiation } \\
\text { Hazard }\end{array}$ \\
\hline 1 & $\begin{array}{l}\text { Fuel receiving } \\
\text { storage }\end{array}$ & Cold prototype & $\begin{array}{l}\text { Shipping cask } \\
\text { and hot cell }\end{array}$ & $\left(\begin{array}{l}(\mathrm{U}, \mathrm{Pu}, \mathrm{Th}) \mathrm{O}_{2} \\
\text { powder }\end{array}\right.$ & LEU & Low & c & Medium \\
\hline 2 & $\begin{array}{l}\text { Pellet sinter- } \\
\text { Ing }\end{array}$ & Hot laboratory & Hot cell & $\mathrm{UO}_{2}$ makeup & MEU & Medium & $\begin{array}{c}a(233 U) \text { or } \\
b(235 U)\end{array}$ & $\begin{array}{l}\text { Medium }(233 \mathrm{U} \\
\text { or Low } \\
(235 \mathrm{U})\end{array}$ \\
\hline 3 & $\begin{array}{l}\text { Fuel pin } \\
\text { assembly }\end{array}$ & $\begin{array}{l}\text { Cold eng1neer- } \\
\text { ing }\end{array}$ & $\begin{array}{l}\text { Hot cell } \\
:\end{array}$ & $\begin{array}{l}\text { Sintered } \\
\text { (U,Pu,Th)O } \\
\text { pellets }\end{array}$ & . & & c. & Medium \\
\hline 4 & $\begin{array}{l}\text { Element } \\
\text { assemb } 1 y\end{array}$ & $\begin{array}{l}\text { Cold engineer- } \\
\text { Ing }\end{array}$ & $\begin{array}{l}\text { Hot cell and } \\
\text { shipping cask }\end{array}$ & $\begin{array}{l}\text { Welded fuel } \\
\text { pins }\end{array}$ & · & & c & Medium \\
\hline 5 & Scrap recovery & Hot 1aboratory & Hot cell & $\begin{array}{l}\text { Miscellaneous } \\
\text { off-spec } \\
\text { material }\end{array}$ & & . & c & $\begin{array}{l}\text { Medium } \\
\text {. }\end{array}$ \\
\hline 6 & $\begin{array}{l}\text { Off-Gas Treat- } \\
\text { men: } \\
\end{array}$ & $\begin{array}{l}\text { Hot engineer- } \\
\text { Ing }\end{array}$ & Hot cell & $\begin{array}{l}\text { Stntering } \\
\text { furnace } \\
\text { effluent }\end{array}$ & . & . & $\begin{array}{l}\text { Non- } \\
\text { fissionable }\end{array}$ & Low \\
\hline
\end{tabular}


Tabie 4.28. Analysis of Fue1 Refabrication Method 3, Flow Diagram 1

Feed: $\quad 233,235,23800_{i=}$ and $(\mathrm{Pu}, \mathrm{Th}) \mathrm{O}_{2}$
Product: (U, Pu, Th) $\mathrm{O}_{2}$ Sintered Pellets Welded in Fuel Pins

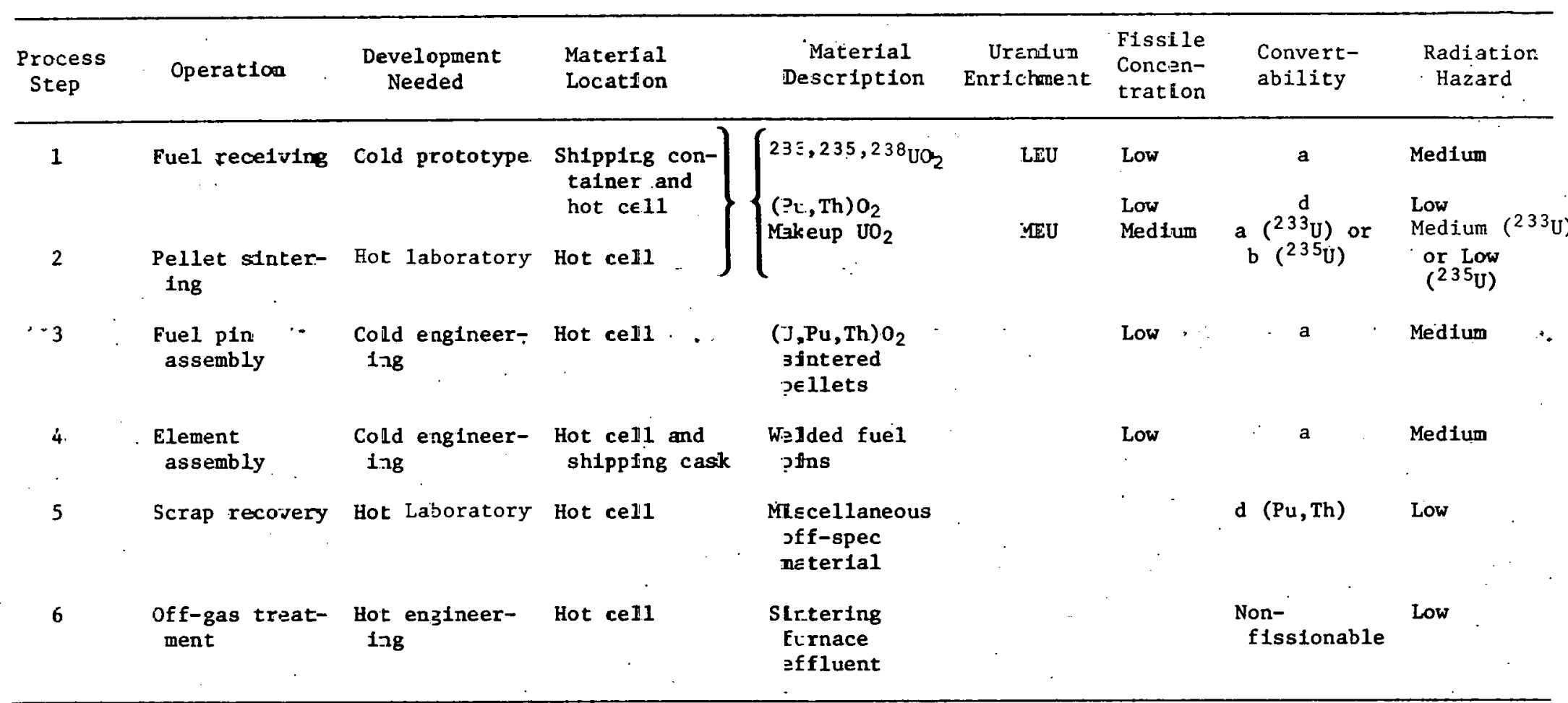


Table 4.29." Analysis of Fuel Refabrication Method 4, Flow Diagram 1

Feed: $\mathrm{PuO}_{2}$ Powder

$2{ }^{38} \mathrm{UO}_{2}$ Powder
Product: (Pu, ${ }^{238} \mathrm{U}_{2} \mathrm{O}_{2}$ Pellets

Welded into Fuel Pins

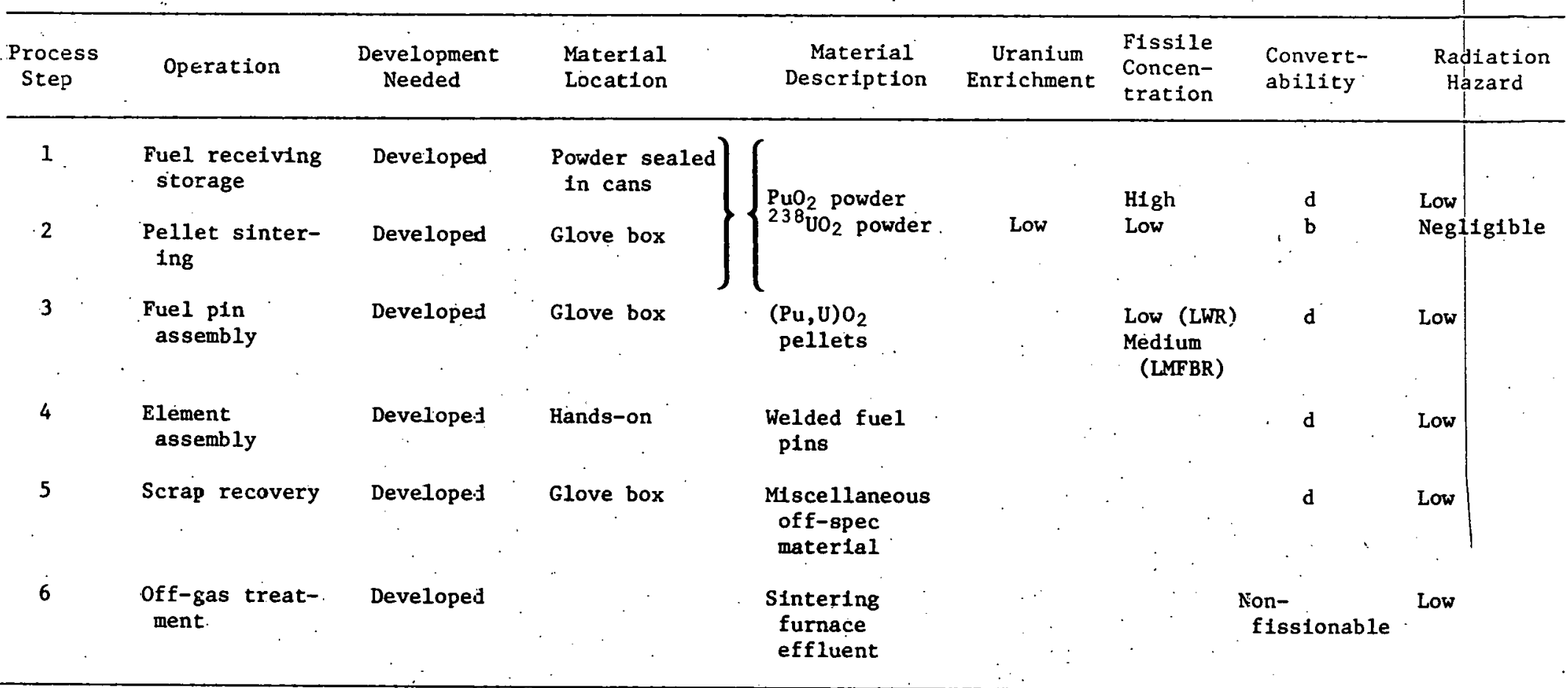


Table 4.30. Analysis of FLe1 Refabrication Method 5. Flow Diegram 1

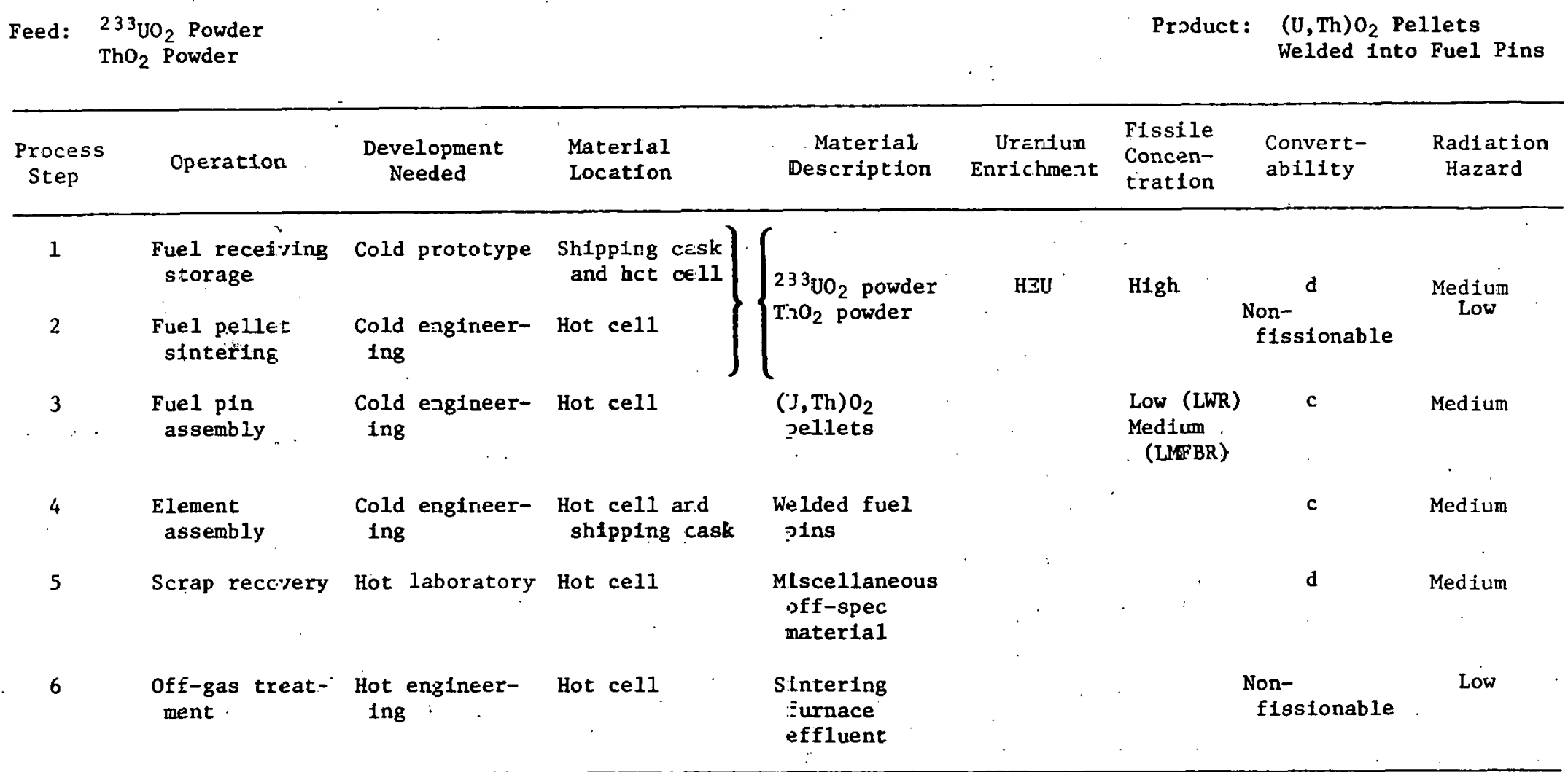


Table 4.31. Analysis of Fuel Refabrication Method 6, Flow Diagram 1

Feed: $\left(233^{3}, \mathrm{Th}\right) \mathrm{O}_{2}$ Powder

Product: $\left({ }^{233} \mathrm{U}, \mathrm{Th}\right) \mathrm{O}_{2}$ Pellets We1ded Into Fuel Pins

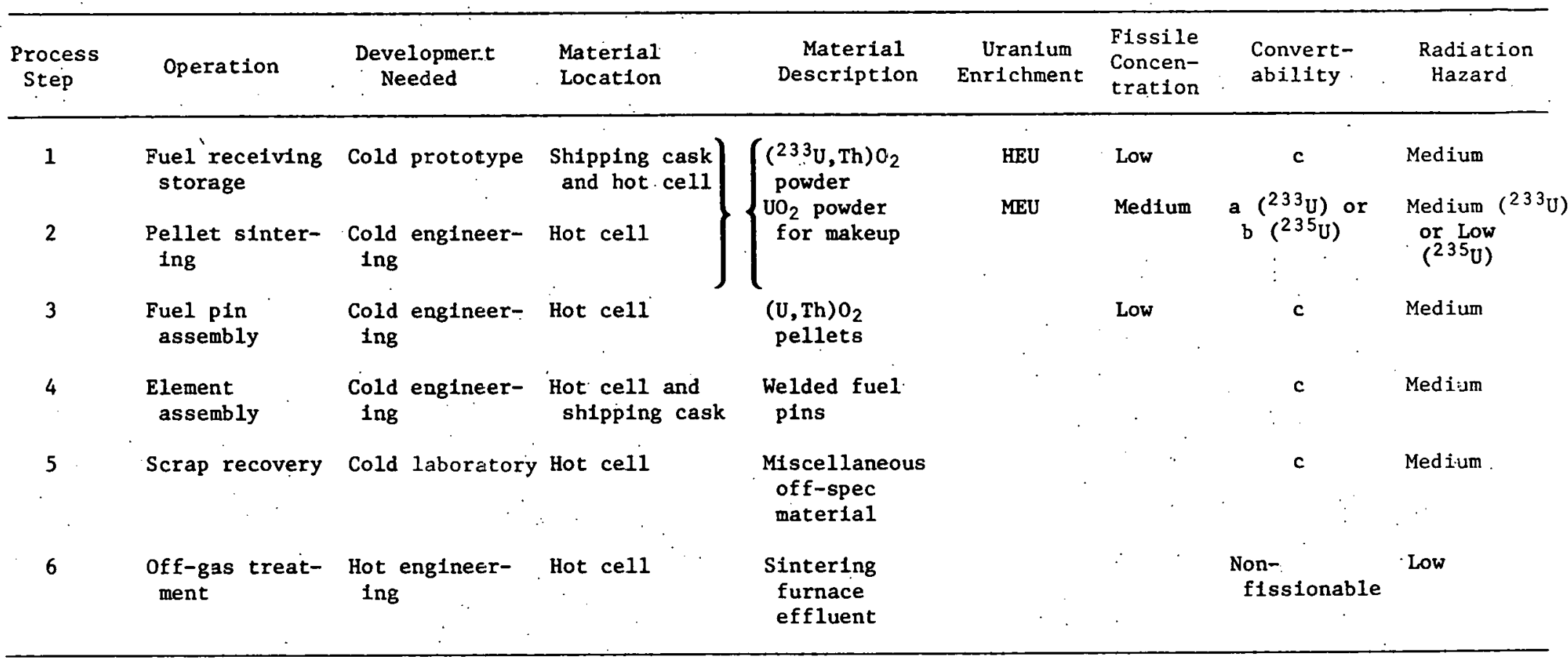


Table 4.3\%. Analysis of Fuel Refabrication Method 7, Flow Diagram 1

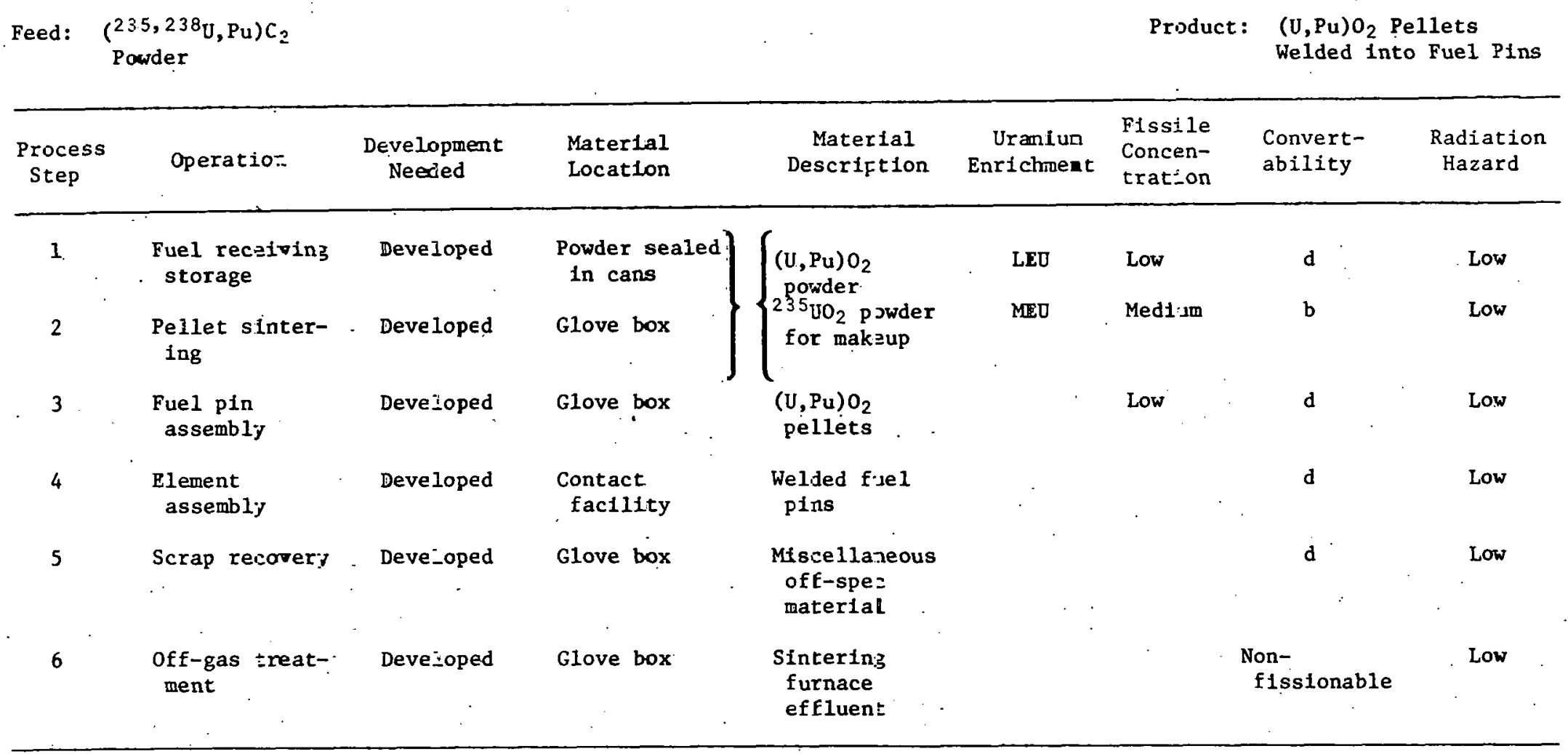


Table 4.33. Analysis of Fuel Refabrication Method 8, Flow Diagram 1

Feed: $233,235,238 \mathrm{UO}_{2}$ Powder

Product: $\mathrm{UO}_{2}$ Pellets Welded $\checkmark \quad$ into Fuel Pins

\begin{tabular}{|c|c|c|c|c|c|c|c|c|}
\hline $\begin{array}{l}\text { Process } \\
\text { Step }\end{array}$ & Operation & $\begin{array}{l}\text { Development } \\
\text { Needed }\end{array}$ & $\begin{array}{l}\text { Material } \\
\text { Location }\end{array}$ & $\begin{array}{c}\text { Material } \\
\text { Description }\end{array}$ & $\begin{array}{c}\text { Uranlum } \\
\text { Enrichment }\end{array}$ & $\begin{array}{l}\text { Fissile } \\
\text { Concen- } \\
\text { tration }\end{array}$ & $\begin{array}{l}\text { Convert- } \\
\text { ability }\end{array}$ & $\begin{array}{l}\text { Radiation } \\
\text { Hazard }\end{array}$ \\
\hline 1 & $\begin{array}{l}\text { Fuel receiving } \\
\text { storage }\end{array}$ & Cold prototype & $\begin{array}{c}\text { Shipping cask } \\
\text { and hot cell }\end{array}$ & \multirow[t]{2}{*}{$\begin{array}{l}\mathrm{UO}_{2} \text { powder } \\
\mathrm{UO}_{2} \text { makeup }\end{array}$} & $\begin{array}{l}\text { LEU } \\
\text { MEU }\end{array}$ & $\begin{array}{l}\text { Low } \\
\text { Medium }\end{array}$ & $a\left({ }^{233} u\right)$ or & \multirow{2}{*}{$\begin{array}{l}\text { Medium } \\
\text { Medium }(233 \mathrm{U}) \\
\text { or low } \\
\left(235_{\mathrm{U}}\right)\end{array}$} \\
\hline 2 & $\begin{array}{l}\text { Pellet sinter- } \\
\text { ing }\end{array}$ & $\begin{array}{l}\text { Cold engineer- } \\
\text { Ing }\end{array}$ & Hot cell. & & & & & \\
\hline 3 . & $\begin{array}{l}\text { Fuel pin } \\
\text { assembly }\end{array}$ & $\begin{array}{l}\text { Cold engineer- } \\
\text { ing. }\end{array}$ & Hot cell & $\begin{array}{c}\text { Sintered } \mathrm{UO}_{2} \\
\text { pellets }\end{array}$ & LEU & Low & $\mathbf{a}$ & Medium \\
\hline 4 & $\begin{array}{l}\text { Element } \\
\text { assembly }\end{array}$ & $\begin{array}{l}\text { Cold engineer- } \\
\text { ing }\end{array}$ & $\begin{array}{l}\text { Hot cell and } \\
\text { shipping cask }\end{array}$ & $\begin{array}{l}\text { Welded fuel } \\
\text { pins }\end{array}$ & . & & $\mathbf{a}$ & Medium \\
\hline 5 & Scrap recovery & $\begin{array}{l}\text { Cold engineer- } \\
\text { ing }\end{array}$ & Hot cell & $\begin{array}{l}\text { Miscellaneous } \\
\text { of } f-s p e c \\
\text { material }\end{array}$ & & & $a$ or $b$ & Medium or low \\
\hline 6 & $\begin{array}{l}\text { off-gas treat- } \\
\text { ment }\end{array}$ & $\begin{array}{l}\text { Hot engineer- } \\
\text { Ing }\end{array}$ & Hct cell & $\begin{array}{l}\text { Sintering } \\
\text { furnace } \\
\text { effluent }\end{array}$ & & & $\begin{array}{l}\text { Non- } \\
\text { fissionable }\end{array}$ & Low \\
\hline
\end{tabular}


Tatle 4.34. Analysis of Fuel Refab-ication Method 9, Flow Diagram 1

Feed: $\mathrm{PuO}_{2}$ Powder $\mathrm{ThO}_{2}$ Powder

Product: ( $\mathrm{Pu}, \mathrm{Th}) \mathrm{O}_{2}$ Pellets Welded Into Fuel Pins.

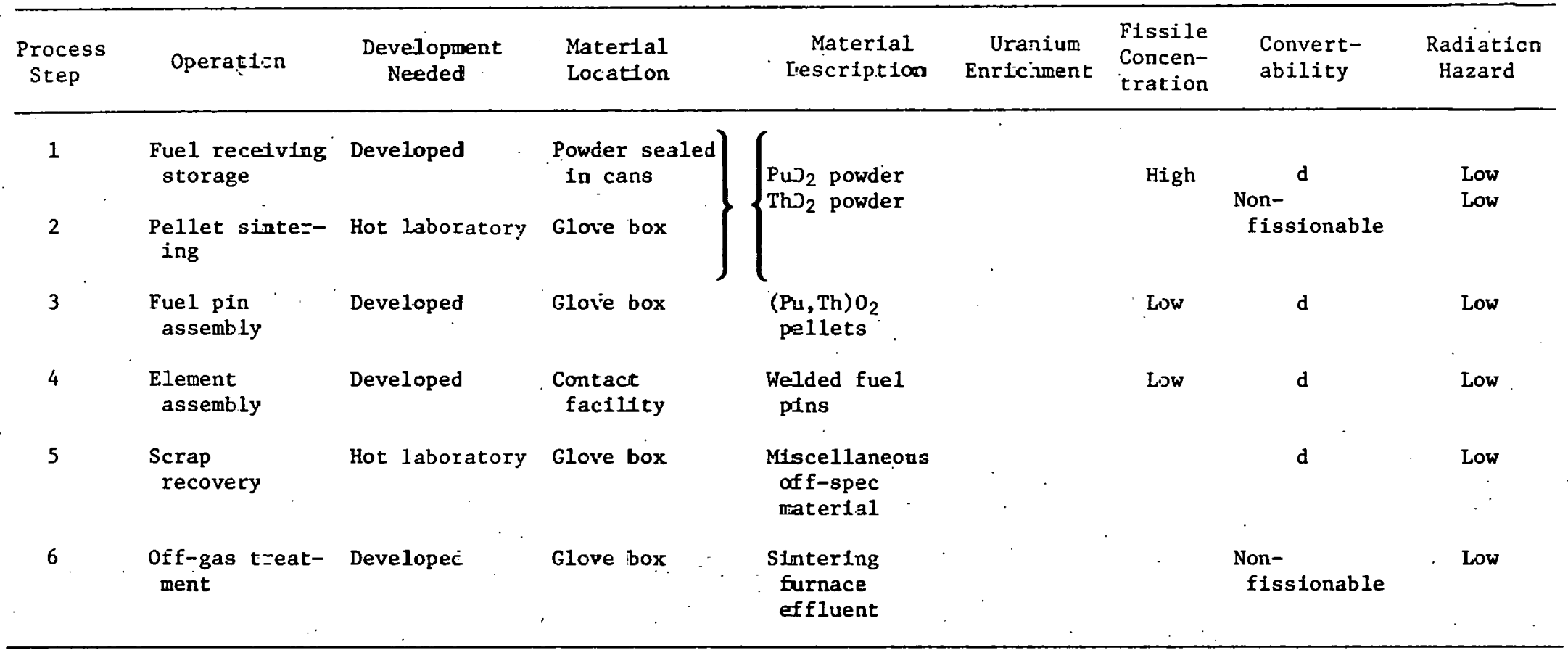


Table 4.35. Anàlysis of Fuel Refabrication Method 10, Flow Diagram 1

Feed: (Pu, Th $) \mathrm{O}_{2} \cdot$ Powder
Product: ( $\mathrm{Pu}, \mathrm{Th}) \mathrm{O}_{2}$ Pellets Welded Into Fuel P1ns

\begin{tabular}{|c|c|c|c|c|c|c|c|c|}
\hline $\begin{array}{l}\text { Process } \\
\text { Step }\end{array}$ & Operation & $\begin{array}{l}\text { Development } \\
\text { Needed }\end{array}$ & $\begin{array}{l}\text { Material } \\
\text { Location }\end{array}$ & $\begin{array}{c}\text { Material } \\
\text { Description }\end{array}$ & $\begin{array}{c}\text { Uranium } \\
\text { Enrichment }\end{array}$ & $\begin{array}{l}\text { Fissile } \\
\text { Concen- } \\
\text { tration }\end{array}$ & $\begin{array}{l}\text { Convert- } \\
\text { ability }\end{array}$ & $\begin{array}{l}\text { Radiation } \\
\text { Hazard }\end{array}$ \\
\hline 1 & $\begin{array}{l}\text { Fuel recelving } \\
\text { storage }\end{array}$ & Developed & $\begin{array}{l}\text { Powder sealed } \\
\text { In cans }\end{array}$ & $(\mathrm{Pu}, \mathrm{Th}) \mathrm{O}_{2}$ powder & $\mathbf{r}$ & Low & $=d$ & Low \\
\hline 2 & $\begin{array}{l}\text { Pellet sinter- } \\
\text { ing. }\end{array}$ & Hot laboratory & Glove box & $\mathrm{PuO}_{2}$ makeup & & H1gh & d & \\
\hline 3 & $\begin{array}{l}\text { Fuel pin } \\
\text { assembly. }\end{array}$ & Developed & Glove box & $\begin{array}{l}(\mathrm{Pu}, \mathrm{Th}) \mathrm{O}_{2} \\
\text { pellets }\end{array}$ & & Low & d & Low \\
\hline 4 & $\begin{array}{l}\text { Element } \\
\text { assembly }\end{array}$ & Developed & $\begin{array}{l}\text { Contact } \\
\text { facility }\end{array}$ & $\begin{array}{l}\text { Welded fuel. } \\
\text { plns }\end{array}$ & . & Low & d & Low \\
\hline 5 & Scrap recovery & Hot laboratory & Glove box & $\begin{array}{l}\text { Miscellaneous } \\
\text { off-spec } \\
\text { material }\end{array}$ & · & . & d d & Low \\
\hline 6 & $\begin{array}{l}\text { Off-zas treat- } \\
\text { ment. }\end{array}$ & Developed & Glove box & $\begin{array}{l}\text { Sintering } \\
\text { furnace } \\
\text { effluent }\end{array}$ & . & & $\begin{array}{l}\text { Non- } \\
\text { fisstonable }\end{array}$ & Low \\
\hline
\end{tabular}


Table 4.36. Analysis of Fue1 Refabrication Method 1.1,

Flow Diagram 1

Feed: $\quad 233,235,238 \mathrm{Ua}_{2}$ Powder $\mathrm{ThO}_{2}$ Powder
Product: (U,Th) $\mathrm{O}_{2}$ Pellets Welded into Fuel Pins

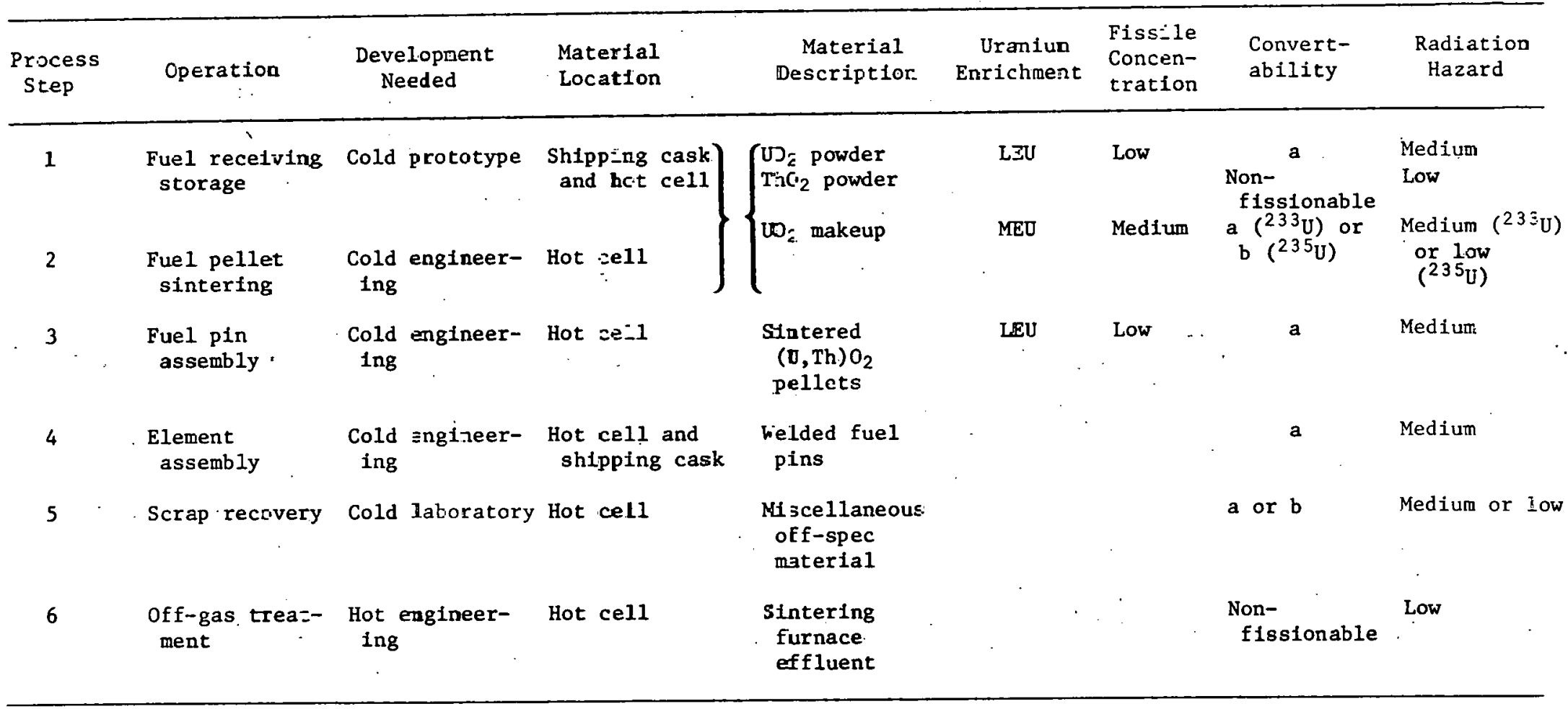


Table 4.37. Analysis of Fuel Refabrication Method 12, Flow Diagram 1

Feed: $\quad(233,235,238 \mathrm{U}, \mathrm{Th}) \mathrm{O}_{2}$ Powder

Feed? $\left(233,235,23 \theta^{2}, \mathrm{Th}_{2} \mathrm{O}_{2}\right.$ Powder

\begin{tabular}{|c|c|c|c|c|c|c|c|c|}
\hline $\begin{array}{l}\text { Process } \\
\text { Step }\end{array}$ & Operation & $\begin{array}{l}\text { Developnent } \\
\text { Needec }\end{array}$ & $\begin{array}{l}\text { Materfal } \\
\text { Location }\end{array}$ & $\begin{array}{c}\text { Material } \\
\text { Description }\end{array}$ & $\begin{array}{c}\text { Uranium } \\
\text { Enrichment }\end{array}$ & $\begin{array}{l}\text { Fissile } \\
\text { Concen- } \\
\text { tration }\end{array}$ & $\begin{array}{l}\text { Convert- } \\
\text { ability }\end{array}$ & $\begin{array}{l}\text { Radiation } \\
\text { Hazard }\end{array}$ \\
\hline 1 & $\begin{array}{l}\text { Fuel recaiving } \\
\text { storage }\end{array}$ & Cold prototype & $\begin{array}{r}\text { Shipping cask } \\
\text { and hot cell }\end{array}$ & {$\left[\begin{array}{l}(\mathrm{U}, \mathrm{Th}) \mathrm{O}_{2} \\
\text { powder }\end{array}\right.$} & & & & \\
\hline 2 & $\begin{array}{l}\text { Pellet sinter- } \\
\text { Ing }\end{array}$ & $\begin{array}{l}\text { Cold engineer- } \\
\text { ing }\end{array}$ & Hot cell & $\mathrm{vO}_{2}$ makeup & MEU & Med1um & $\begin{array}{c}a(233 \mathrm{U}) \text { or } \\
\mathrm{b} \cdot\left(235_{\mathrm{U}}\right)\end{array}$ & Medium or \\
\hline 3 & $\begin{array}{l}\text { Fuel pin } \\
\text { assembly }\end{array}$ & $\begin{array}{l}\text { Cold engineer- } \\
\text { Ing }\end{array}$ & Hot cell & $\begin{array}{l}\text { Sintered } \\
(\mathrm{U}, \mathrm{Th}) \mathrm{O}_{2} \\
\text { pellets }\end{array}$ & LEU & Low & . $\mathbf{a}$ & Medium \\
\hline 4 & $\begin{array}{l}\text { Element } \\
\text { assembly }\end{array}$ & $\begin{array}{l}\text { Cold engineer- } \\
\text { Ing }\end{array}$ & $\begin{array}{l}\text { Hot cell and } \\
\text { shipping cask }\end{array}$ & $\begin{array}{l}\text { Welded fuel } \\
\text { pins }\end{array}$ & & & $\mathbf{a}$ & Medium \\
\hline 5 & Scrap recovery & Cold laboratory & Hot cell & $\begin{array}{l}\text { Miscellaneous } \\
\text { off-spec } \\
\text { materlal }\end{array}$ & & & $a$ or $b$ & Medium or \\
\hline 6 & $\begin{array}{l}\text { Off-gas treat- } \\
\text { ment }\end{array}$ & $\begin{array}{l}\text { Hot engineer- } \\
\text { ing }\end{array}$ & Hot cell & $\begin{array}{l}\text { Sintering } \\
\text { furnace } \\
\text { effluent }\end{array}$ & & & $\begin{array}{l}\text { Non- } \\
\text { fissionable }\end{array}$ & Low \\
\hline
\end{tabular}

Product: (U, Th) $\mathrm{O}_{2}$ Pellets Welded Into Fuel Pins

光


Table 4.38, Aralysis of Fiel Refabrication Məthod 13, F1Cw Diagram 1

\begin{tabular}{|c|c|c|c|c|c|c|c|c|}
\hline Feed: & 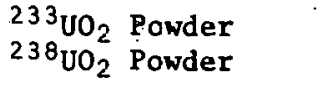 & & - & & & Product: & $\begin{array}{l}\mathrm{UO}_{2} \text { Pellets } \\
\text { into Fuel } \mathrm{P}\end{array}$ & $\begin{array}{l}\text { Welded } \\
\text { ns }\end{array}$ \\
\hline $\begin{array}{l}\text { Process } \\
\text { Step }\end{array}$ & Operation & $\begin{array}{l}\text { Development } \\
\text { Needed }\end{array}$ & $\begin{array}{l}\text { Material } \\
\text { Location }\end{array}$ & $\begin{array}{c}\text { Material } \\
\text { Description }\end{array}$ & $\begin{array}{c}\text { Uran:um } \\
\text { Enrl=hnent }\end{array}$ & $\begin{array}{l}\text { Fissile } \\
\text { Concen- } \\
\text { tration }\end{array}$ & $\begin{array}{l}\text { Convert- } \\
\text { ability }\end{array}$ & $\begin{array}{c}\text { Radiation } \\
\text { Hazarć }\end{array}$ \\
\hline 1 & $\begin{array}{l}\text { Fuel recelvirg } \\
\text { storage }\end{array}$ & Cole prototype & $\begin{array}{c}\text { Shipping cask } \\
\text { and hot cell }\end{array}$ & $\begin{cases}23{ }^{3} \mathrm{UO}_{2} & \text { powder } \\
238^{8} \mathrm{UO}_{2} & \text { powder }\end{cases}$ & $\begin{array}{l}\text { EEU } \\
\text { LEU }\end{array}$ & $\begin{array}{l}\text { High } \\
\text { Low }\end{array}$ & $\begin{array}{l}\mathrm{d} \\
\mathrm{b}\end{array}$ & $\begin{array}{l}\text { Medium } \\
\text { Low }\end{array}$ \\
\hline 2 & $\begin{array}{l}\text { Fuel pellet } \\
\text { sinter1ing }\end{array}$ & $\begin{array}{l}\text { Cold engineer- } \\
\text { Ing }\end{array}$ & Hot cell & & & & & \\
\hline 3 & $\begin{array}{l}\text { Fuel pin } \\
\text { assembiy. }\end{array}$ & $\begin{array}{l}\text { Cold engineer- } \\
\text { Ing }\end{array}$ & Ho: cell & {$\left[\mathrm{TO}_{2}\right.$ pellets } & LEL & $\begin{array}{l}\text { Low (LWR) } \\
\text { Medium } \\
\text { (LMFBR) }\end{array}$ & $\mathbf{a}$ & Medium \\
\hline 4 & $\begin{array}{l}\text { Element } \\
\text { asserb-y }\end{array}$ & $\begin{array}{l}\text { Cold engineer- } \\
\text { Ing. }\end{array}$ & $\begin{array}{l}\text { Hot cell and } \\
\text { silpping cask }\end{array}$ & $\begin{array}{l}\text { Velded fuel. } \\
\text { pins }\end{array}$ & & & a & Yedium \\
\hline 5 & Scrap recover: & Hot lab.oratcry & Hot cell & $\begin{array}{l}\text { Miscellaneous } \\
\text { off-spec } \\
\text { materfal }\end{array}$ & & & $\mathrm{d}$ & Medium \\
\hline 6 & $\begin{array}{l}\text { Off-ges } \operatorname{tr} \in \mathrm{a}=- \\
\text { ment }\end{array}$ & $\begin{array}{l}\text { Hot engineer- } \\
\text { ing }\end{array}$ & Hot cell & $\begin{array}{l}\text { Sintering } \\
\text { furnace } \\
\text { effluent }\end{array}$ & & & $\begin{array}{l}\text { Yon- } \\
\text { fissionable }\end{array}$ & Low \\
\hline
\end{tabular}




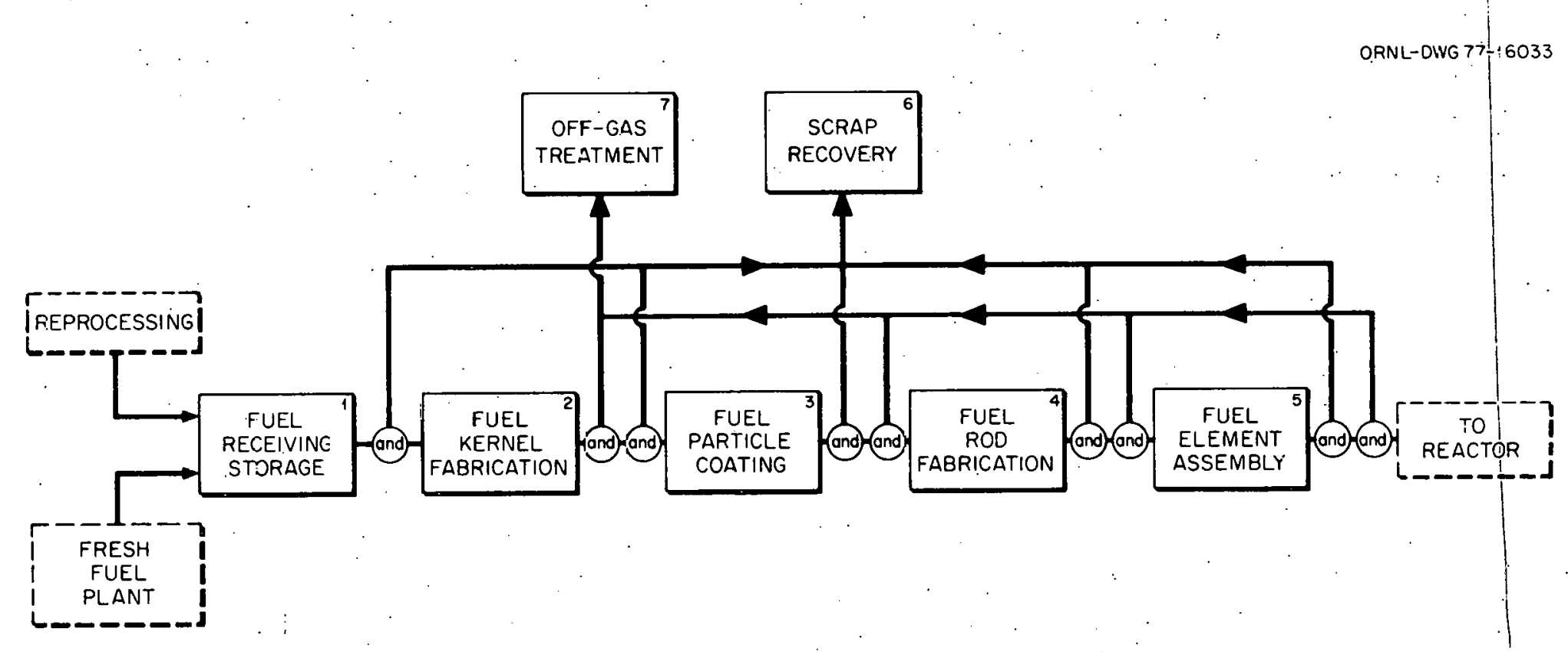

Fig. 4.23. Diagram. 2: Level 1 Functional Flow Diagram: HTGR Fuel Element Fabrication. 
Ta: 1 le 4.39. Aralysis of Fuel Fabrication Metiod 14, F1cw Diagram 2

Feed: $\mathrm{Pu}\left(\mathrm{NO}_{3}\right)_{4}$ Soluticn

$235,23 \mathrm{UO}_{2}\left(\mathrm{Ni}_{3}\right)=$ solution
Product: Coated (U, $\mathrm{Pu})_{2}$ Fue1 Particles Within a

Graphite Fuel Element

\begin{tabular}{|c|c|c|c|c|c|c|c|c|c|}
\hline $\begin{array}{l}\text { Process } \\
\text { Step }\end{array}$ & Operation & $\begin{array}{l}\text { Development } \\
\text { NeEded }\end{array}$ & $\begin{array}{l}\text { Materlal } \\
\text { Location }\end{array}$ & $\begin{array}{l}\text { Material } \\
\text { Lescription }\end{array}$ & $\begin{array}{c}\text { Uranitm } \\
\text { Enri }=\text { bment }\end{array}$ & $\begin{array}{l}\text { Fissile } \\
\text { Concen- } \\
\text { tration }\end{array}$ & $\begin{array}{l}\text { Convert- } \\
\text { ability }\end{array}$ & & $\begin{array}{l}\text { Radiation } \\
\text { Hazard }\end{array}$ \\
\hline 1 & $\begin{array}{l}\text { Fuel receiving } \\
\text { storage }\end{array}$ & $\begin{array}{l}\text { Hot er.ginaer- } \\
=\mathrm{ng}\end{array}$ & Glove: box & $\begin{array}{c}\left.\mathrm{Fu}^{-} \mathrm{NO}_{3}\right)_{L} \\
\text { solution }\end{array}$ & & High & $d$ & & Low \\
\hline 2 & $\begin{array}{l}\text { Fuel kernel } \\
\text { fabrication }\end{array}$ & $\begin{array}{l}\text { Hot englneer- } \\
\text { ing }\end{array}$ & Glove jox & $\begin{array}{r}\mathrm{CO} \cdot\left(\mathrm{NO}_{3}\right)_{2} \\
\text { solution }\end{array}$ & LEJ & Low & b $b$ & . & Low \\
\hline 3 & $\begin{array}{l}\text { Fuel particle } \\
\text { coating. }\end{array}$ & $\begin{array}{l}\text { Hot englneer- } \\
\text { ing. }\end{array}$ & Glove jox & $\begin{array}{l}\mathrm{U}, \mathrm{Pu}) \mathrm{O}_{2} \text { fuel } \\
\text { kernels }\end{array}$ & L.EU & Medium & d & & Low \\
\hline 4 & $\begin{array}{l}\text { Fuel rod } \\
\text { fabrication. }\end{array}$ & Cold prototype & Glove box & $\begin{array}{l}\text { Cozted fuel } \\
\text { particles }\end{array}$ & . & & $d$ & & Low \\
\hline 5 & $\begin{array}{l}\text { Fuel element } \\
\text { assembly }\end{array}$ & Cold prototype & Glave box & $\begin{array}{l}\text { Pitch bonded } \\
\text { fuel rods }\end{array}$ & . & & d & & Low \\
\hline 6 & Scrap recovery & $\begin{array}{l}\text { Hot engireer- } \\
\text { Ing }\end{array}$ & Glove box & $\begin{array}{l}\text { Utscellaneous } \\
\text { off-spec } \\
\text { materlal }\end{array}$ & - & r. & d & & Low \\
\hline 7 & $\begin{array}{l}\text { Off-gas treat- } \\
\text { ment }\end{array}$ & Developed & Glove box & $\begin{array}{l}\text { Radioactive } \\
\text { gases }\end{array}$ & & & $\begin{array}{l}\text { Non- } \\
\text { fissionable }\end{array}$ & & Low \\
\hline
\end{tabular}


Table 4.40. Analysis of Fuel Fabrication Method 15, F1ow Diagram 2

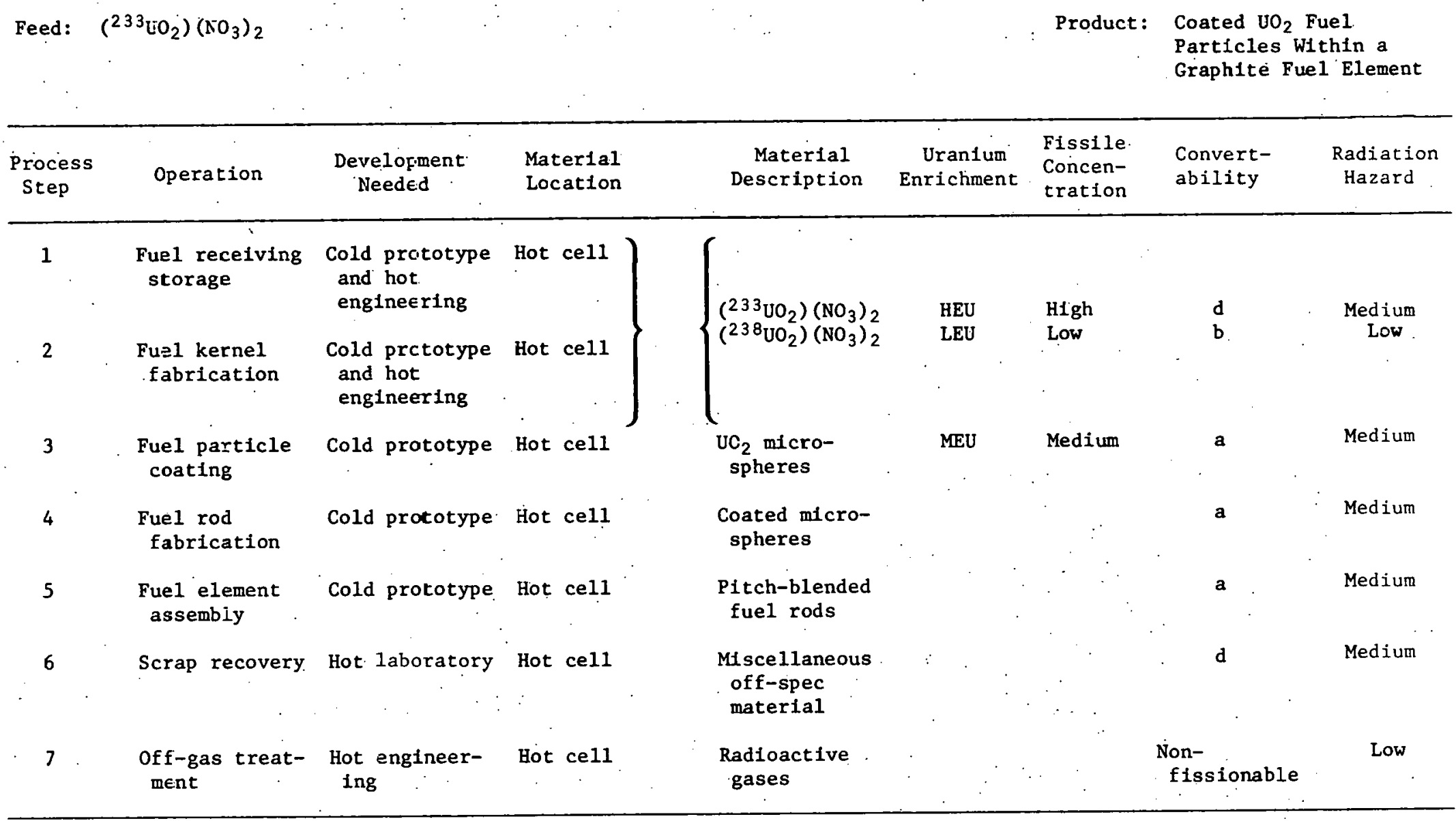


Tatile 4.41. Anaiysis of Fuel Fabricaiion Method 16, Flow Diagram 2

Feed: Mixed Solutions of Th and ${ }_{23}^{3} \mathrm{U}$ n 1 trate
Product: Coated (U, Th) $\mathrm{O}_{2}$ Fue 1 Particles Within a Graphite Fuel Element

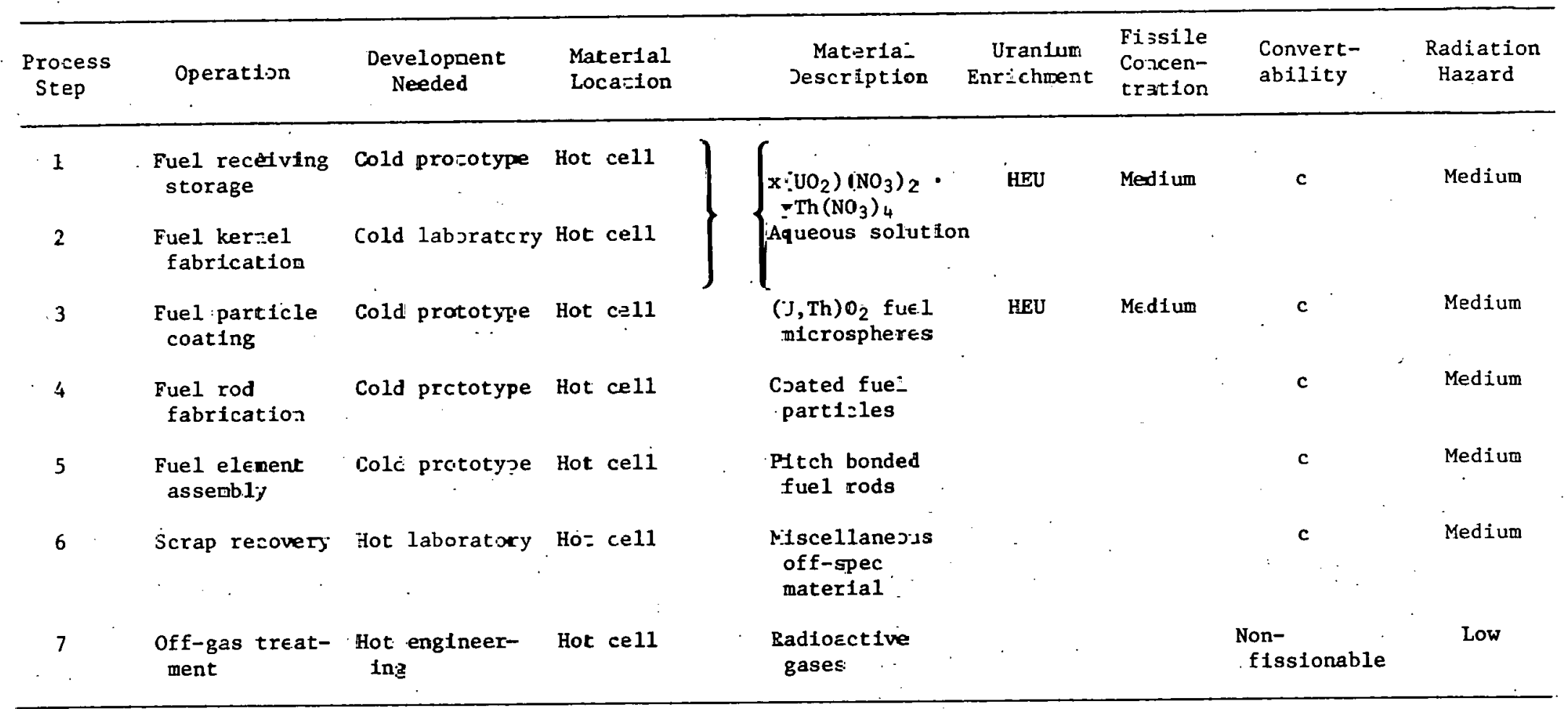


Table 4.42. Analysis of Fuel Fabrication Method 17, Flow Diagram 2

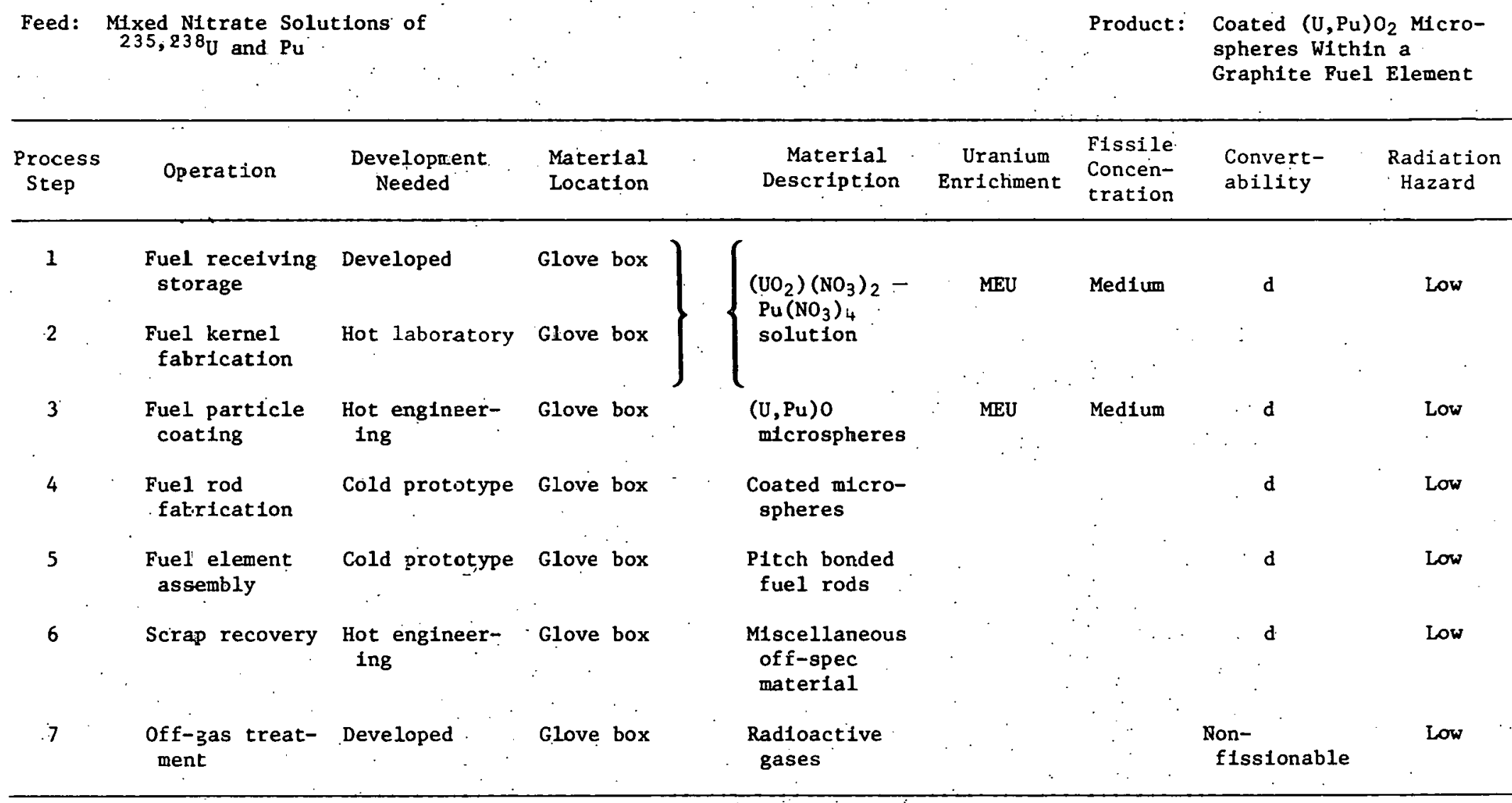


Table 4.43. Anaiysis of Fuel Fabrication Method 18, Flow Diagram 2

Feed: $\mathrm{Pu}\left(\mathrm{NO}_{3}\right)_{4}$ Solution
Product: Coated $\mathrm{PuO}_{2}$ Microspheres Combined with Coated $\mathrm{ThO}_{2}$ Microspheres in a Graphite Fuel Element

\begin{tabular}{|c|c|c|c|c|c|c|c|c|}
\hline $\begin{array}{l}\text { Process } \\
\text { Step }\end{array}$ & Operation & $\begin{array}{l}\text { Development } \\
\text { Needed }\end{array}$ & $\begin{array}{l}\text { Mcterial } \\
\text { Lacation }\end{array}$ & $\begin{array}{c}\text { Material } \\
\text { Description }\end{array}$ & $\begin{array}{c}\text { Uranium } \\
\text { Enrichnent }\end{array}$ & $\begin{array}{l}\text { Fissile } \\
\text { Concen- } \\
\text { tration }\end{array}$ & $\begin{array}{l}\text { Convert- } \\
\text { ability }\end{array}$ & $\begin{array}{l}\text { Raciation } \\
\text { Hazard }\end{array}$ \\
\hline 1 & Fuel recelving & Deveioped & Glove box & & & & & \\
\hline 2 & $\begin{array}{l}\text { storage } \\
\text { Fuel kerzel } \\
\text { fabrication }\end{array}$ & Jot ¿abcrato=y & Glove box & $\begin{array}{l}\mathrm{Pu}\left(\mathrm{NO}_{3}\right)_{4} \\
\text { solution }\end{array}$ & & Hizh & $d$ & Low \\
\hline 3 & $\begin{array}{l}\text { Fuel particle } \\
\text { coating }\end{array}$ & $\begin{array}{l}\text { Hot engineer- } \\
\text { Ing }\end{array}$ & Glore box & $\begin{array}{l}\mathrm{FuO}_{2} \text { micro- } \\
\text { spheres }\end{array}$ & & High & $\mathrm{d}$ & Low \\
\hline 4 & $\begin{array}{l}\text { Fuel rod } \\
\text { fabric } \equiv t i o n\end{array}$ & Cold prototype & Glove box & $\begin{array}{l}\text { Coatec } \mathrm{PuO}_{2} \\
\text { microspheres }\end{array}$ & & - & $d$ & Low \\
\hline 5 & $\begin{array}{l}\text { Fuel element } \\
\text { assembly }\end{array}$ & Colc prototspe & Glowe box & $\begin{array}{l}\text { Pitch bonded } \\
\text { fuel rods }\end{array}$ & & . & d & Low \\
\hline 6 & Scrap recoyery & Hot latoratory & Glcve box & $\begin{array}{l}\text { Miscellaneous } \\
\text { off-spec } \\
\text { material }\end{array}$ & & - & d & Low \\
\hline 7 & $\begin{array}{l}\text { off-gas treet- } \\
\text { ment }\end{array}$ & Developed & Glove box & $\begin{array}{l}\text { Radioactive } \\
\text { gases }\end{array}$ & : & & $\begin{array}{l}\text { Non- } \\
\text { fissionable }\end{array}$ & Low \\
\hline
\end{tabular}


Tab13 4.44. Analysis of Fuel Fabrication Method 19, Flow. Diagram 2

Feed: $\quad{ }^{23}{ }^{3} \mathrm{UO}_{2}\left(\mathrm{NO}_{3}\right)_{2}$ Solutions, HEU and LEU

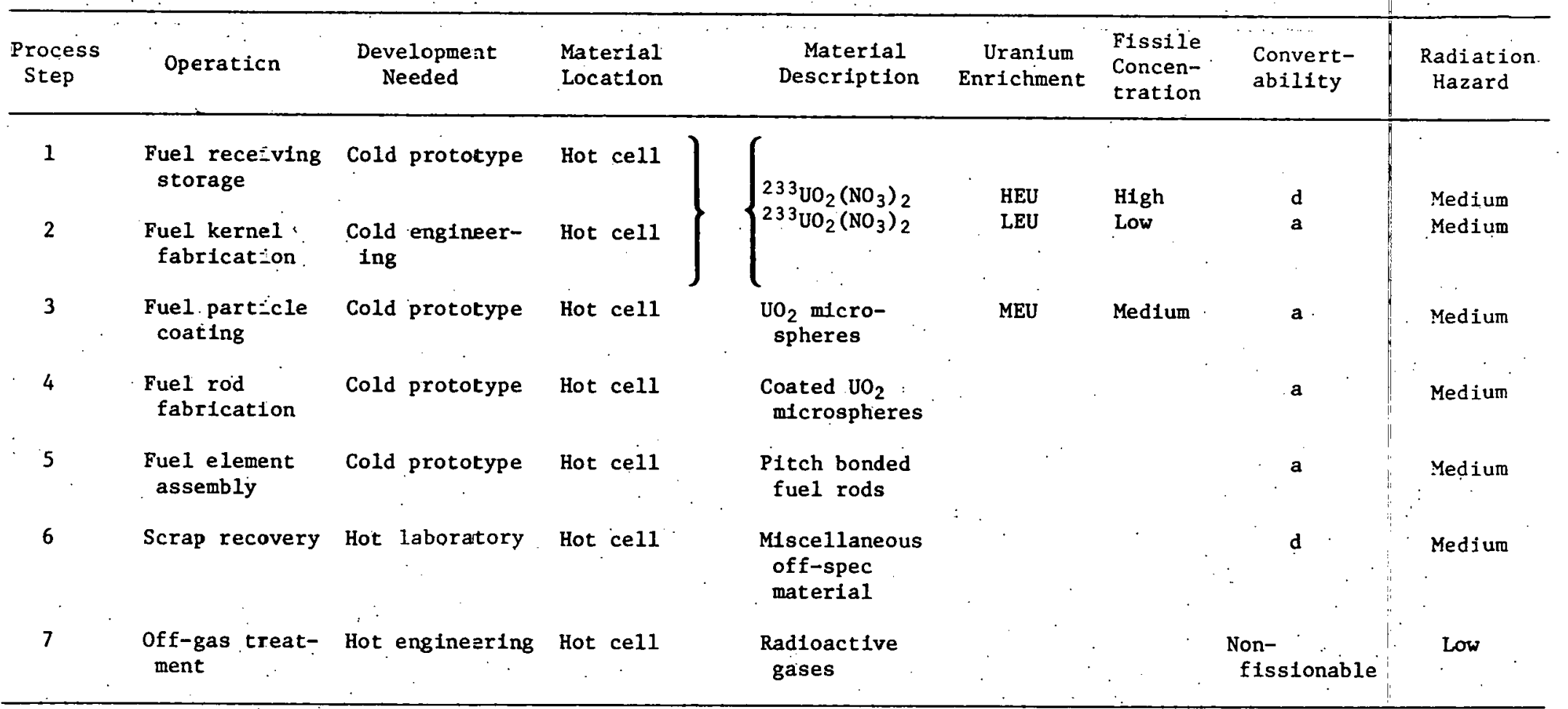

Product: Coated $\mathrm{UO}_{2} \mathrm{MJ}$ crospheres in a Graphite Fuel Element

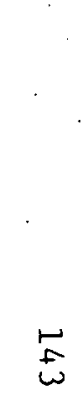


Table 4.45. Analysis of Fuel Fabrication Method 20, Flow Diagram 2

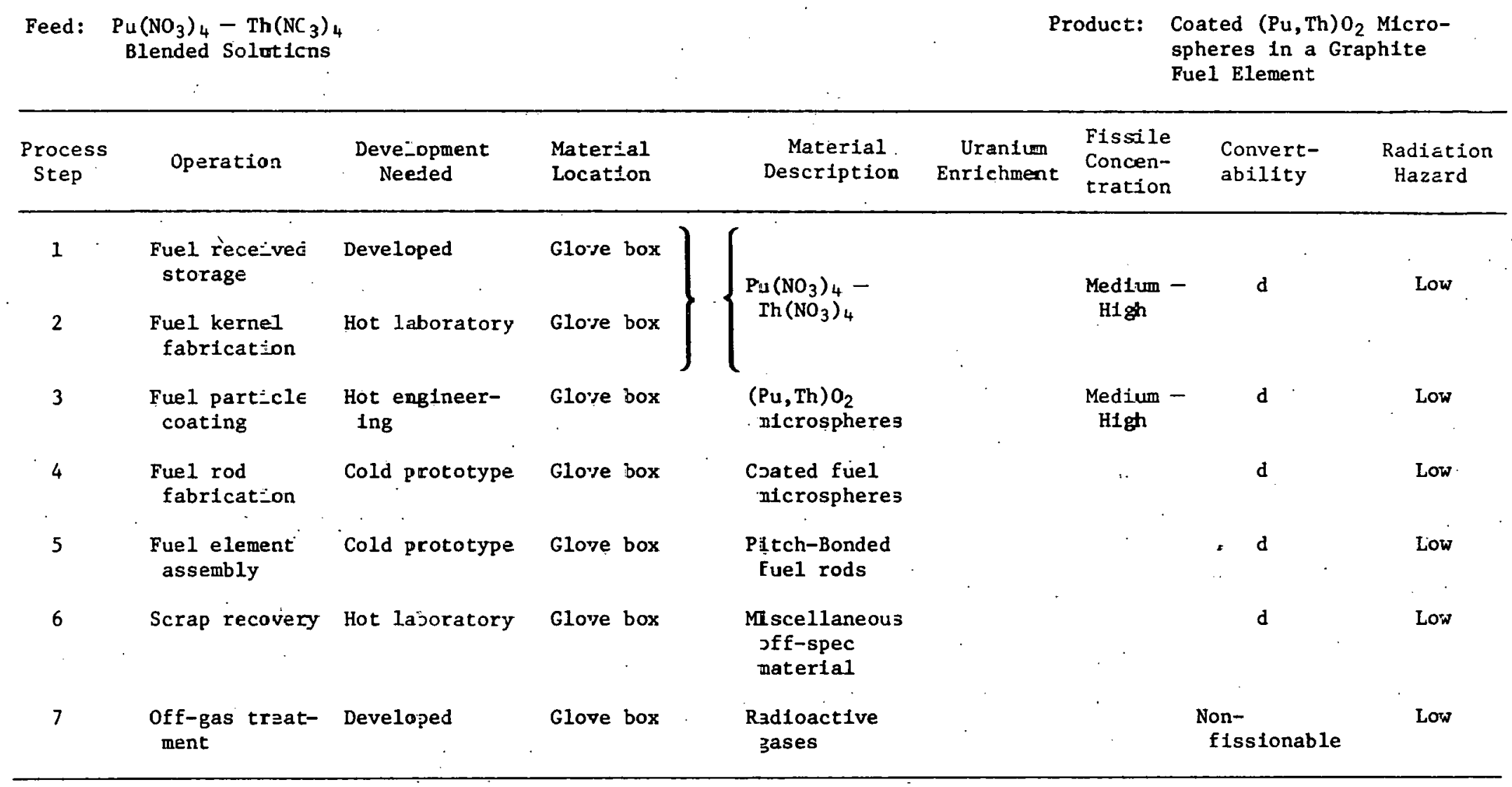


Table 4.46: Analysis of Fuel Fabrication Method 21, Flow Diagram 2

Feed: ${ }^{233} \mathrm{UO}_{2}\left(\mathrm{NO}_{3}\right)_{2}$ Solution
Product: Coated. $\mathrm{UO}_{2}$ Microspheres W1thin Sphericall Graphite Fuel- Elements

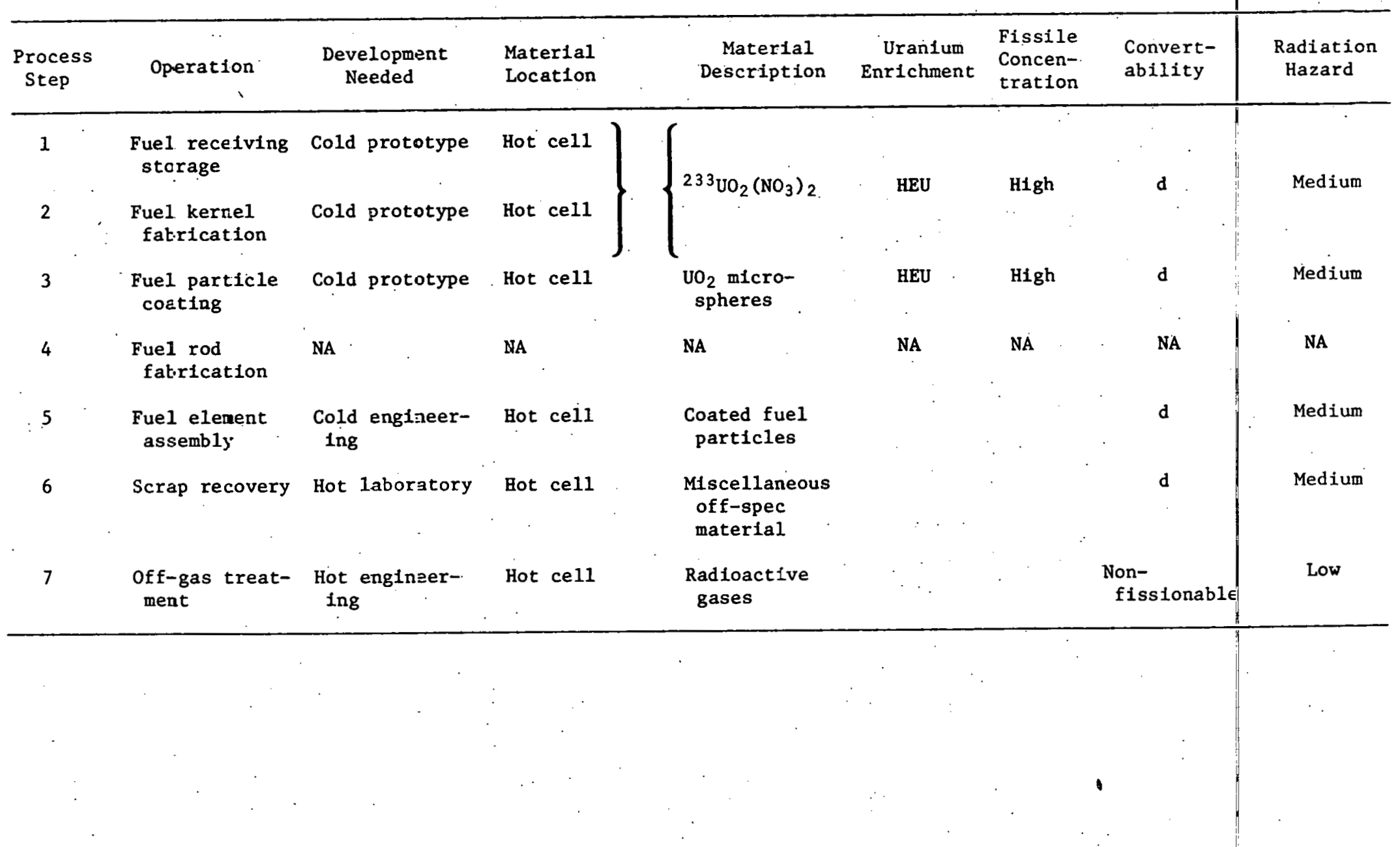




\section{THIS PAGE \\ WAS INTENTIONALLY \\ LEFT BLANK}




\title{
5. FUEL CYCLE EVALUATIONS FOR URANIUM-PLUTONIUM FUELS IN LWRS (Savannah River Laboratory)
}

Savannah River Laboratory

\author{
E. I. du Pont de Nemours and Co. \\ Aiken, South Carolina
}

F. R. Field and F. E. Driggers

\subsection{INTRODUCTION}

The President's Nuclear Policy Statement of October 28, 1976, identified activities by the U.S. Government to reduce the risk of nuclear weapon proliferation while providing for the continued use of nuclear power worldwide. The United States Energy Research and Development Administration (ERDA) is developing a Nonproliferation Alternative Systems Assessment Program (NASAP) to implement the Nuclear Policy Statement. As shown in Figure 5.1, a cooperative program to identify and evaluate alternative nuclear fuel cycles is under the direction of the Division of Nuclear Research and Applications (NRA); the Division of Waste Management, Production, and Reprocessing (WPR); and the Division of Safeguards and Security (DSS). The objective of this program is to define viable fuel cycles which have the most potential for reducing the risks of nuclear weapon proliferation. Laboratories currently participating in the WPR program are:

Argonne National Laboratory (ANL)

Hanford Engineering Development Laboratory (HEDL)

Oak Ridge National Laboratory (ORNL)

Savannah. Kiver Laboratory (SKL)

The study of alternative fuel cycles is proceeding in phases; in Phase 1 , the interest is to consider a wide range of possible fuel cycles. In Phase 2, the number of fuel cycles will be reduced for detailed study.

* The information contained in this article was developed during the course of work under Contract No. AT(07-2)-1 with the U.S. Energy Research and Development. Administration. 


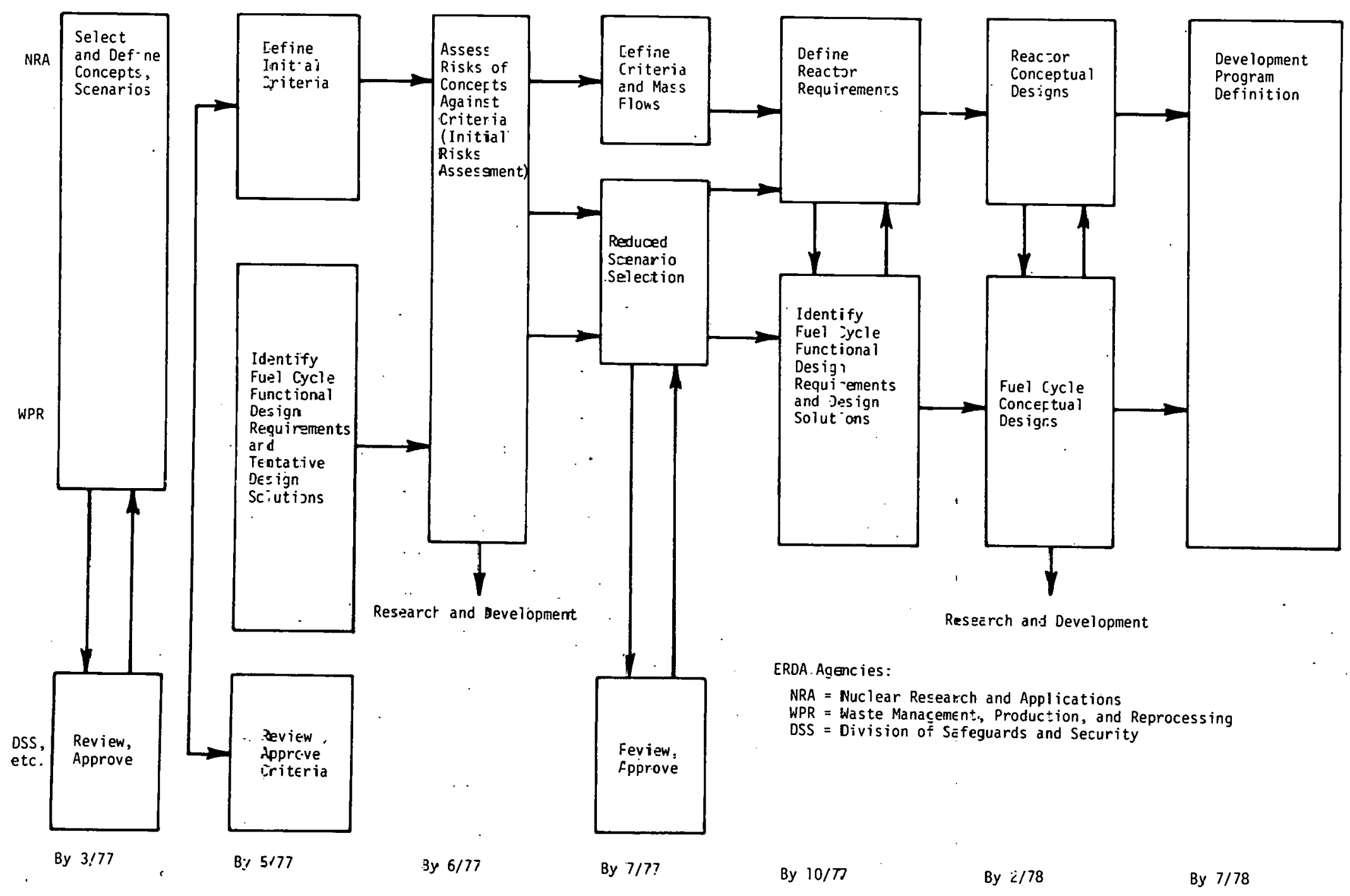

Fig. 5.1. Schedule for Assessment of Alternative Fuel Cycles 
This report combines three previous Phase 1 SRL reports into a single document describing 16 fuel cycles (Table 5.1) and completes Phase 1 for SRL. The diagrams for the 16 fuel cycles cover two levels, Level 0 and Level 1. Level 0 is defined to include the major segments of a fuel cycle such as Enrichment, Keprocessing, Terminal Waste Storage, Mixed Oxide (MOX) Fuel Fabrication, etc., while Level 1 identifies major process steps within each segment; i.e.; shearing fuel and solvent extraction are process steps for the Reprocessing segment. In Phase 2, Level 2 diagrams will expand Level 1 processes to detailed equipment operations. Costs and resource demands will be included.

Each Level 1 diagram is complemented by a table that describes the development status of each process and some of the relevant characteristics of the material in process (fissionable content, radiation level, etc.). The development status will be used to estimate the cost and time frame for development of such a fuel cycle. The material characteristics are intended to be used to analyze the relative resistance to proliferation of a fuel cycle or to compare fuel cycles to other non-fuel cycle paths to proliferation (e.g., research reactor or enrichment plant). The methods to analyze fuel cycles are to be developed by Science Applications, Iric., under contract to the NRA.

\subsection{DISCUSSION}

The 16 cases (Table 5.1) are discussed individually. Seven cases are associated with the light water reactor (LWR). Two cases concerning the yas-cuoled reactor (GCR) are derived from generic LWR cases. Three cases concern the heavy water reactor (HWR), three cases involve hybrid LWR-HWR operation, and the final case, energy center (EC), is a combination of fuel cycle cases.

\subsubsection{Case 1.1.1 (LWR): Recycle of Uranium and Plutonium (Base)}

The itajur segments of this fuel cycle (Level 0 ) are shown schematically in Figure 5.2. Major process steps (Level 1) are shown in Figures 5.3, 5.4, and 5.5. The state-of-the-art and material characteristics for the chemical 
Table 5.1. Fuel Cycle Alternatives

\begin{tabular}{|c|c|c|c|c|}
\hline Cas & e Description & Case Number & Tables & $\begin{array}{l}\text { Process } \\
\text { Figures }\end{array}$ \\
\hline \multirow[t]{8}{*}{ A. } & $\underline{\mathrm{LWR}}$ & & & \\
\hline & Recycle of Uranium and Plutonium (Reference) & 1.1 .1 & 5.2 & $5.2-5.5$ \\
\hline & Recycle of Uranium and Spiked Plutonium & 1.1 .2 . & 5.3 & $5.6-5.9$ \\
\hline & $\begin{array}{l}\text { Recycle of Uranium and Spiked Uranium - } \\
\text { Plutonium Oxide (Coprocessed) }\end{array}$ & 1.1 .3 & 5.4 & $5.10-5.13$ \\
\hline & $\begin{array}{l}\text { Recycle of Uranium; Plutonium Diverted to } \\
\text { High Activity Waste Stream }\end{array}$ & 1.1 .4 & 5.5 & $5.14-5.16$ \\
\hline & Fuel Throwaway - Oxide Fuel & 1.1 .5 & 5.6 & $5.17-5.19$ \\
\hline & Fuel Tlıúwáwày a Metal Fuel & 1.1 .6 & 5.7 & $5.20 \quad 5.32$ \\
\hline & $\begin{array}{l}\text { Recycle of Uranium and Uranium-Plutonium } \\
\text { Oxide (Coprocessed) }\end{array}$ & 1.1 .7 & 5.9 & $5.23-5.26$ \\
\hline \multirow[t]{3}{*}{$\overline{\mathrm{B}}$. } & $\underline{\text { Gas-Cooled Reactors }}^{a}$ & , & & \\
\hline & Fuel Throwaway - Metal Fuel (Magnox) & 2.1 .6 & 5.10 & $5.27-5.29$ \\
\hline & $\begin{array}{l}\text { Recycle of Uranium and Plutonium in } \\
\text { Advanced Gas Reactors (Oxide Fuel) }\end{array}$ & $2.1: 7$ & 5.11 & $5.30-5.33$ \\
\hline \multirow[t]{4}{*}{ C. } & $\underline{\mathrm{HWR}}$ & & & \\
\hline & Recycle of Plutonium ${ }^{b}$ & 3.1 .1 & 5.12 & $5.34-5.37$ \\
\hline & Recycle of Spiked Plutoniumb & 3.1 .2 & 5.13 & $5.38-5.41$ \\
\hline & $\begin{array}{l}\text { Fuel Throwaway - Oxide Fue }{ }^{b} \\
\text { LWR-HWR Hybr1ds }\end{array}$ & 3.1 .3 & 5.14 & $5.42-5.44$ \\
\hline \multirow{3}{*}{ i. } & Tandem Cycle - Reconstituted LWR Fuel & 3.3 .1 & 5.15 & $5.45-5.48$ \\
\hline & $\begin{array}{l}\text { Tandem Cycle - Fuel not Reconstituted } \\
\quad \text { (LWR fuel compatible with HWR operation) }\end{array}$ & 3.3 .2 & 5.16 & $5.49-5.51$ \\
\hline & $\begin{array}{l}\text { Spectral Shift Reactor - Throwaway of } \\
\text { Oxide. Fllel (I,WR-HWR hyhrid) }\end{array}$ & 3.4 .1 & $5.1 \%$ & $5.52-5.53$ \\
\hline \multirow[t]{2}{*}{$\mathrm{F}$. } & Fnergy rentere & · & & \\
\hline & $\begin{array}{l}\text { U-Pu LWR with Recycle of Pu Fuel Inside } \\
\text { Center; U Fueled LWR Outside Center, } \\
\text { Irradiated Fuel Transferred to } \\
\text { Lnergy Center }\end{array}$ & 7.1 .1 & 5.18 & $5.54-5.58$ \\
\hline
\end{tabular}

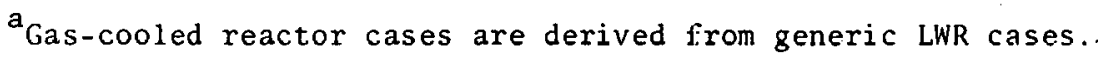

${ }^{b}$ HWR cases are derived from generic LWR cases, except uranium is not recycled because of $10 w^{235} \mathrm{U}$ content.

${ }^{c}$ Derived from the previous tandem case.

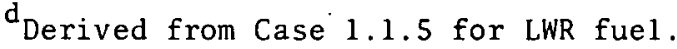

energy center cases are combinations of other fuel cycle cases.
} 
LEVEL 0

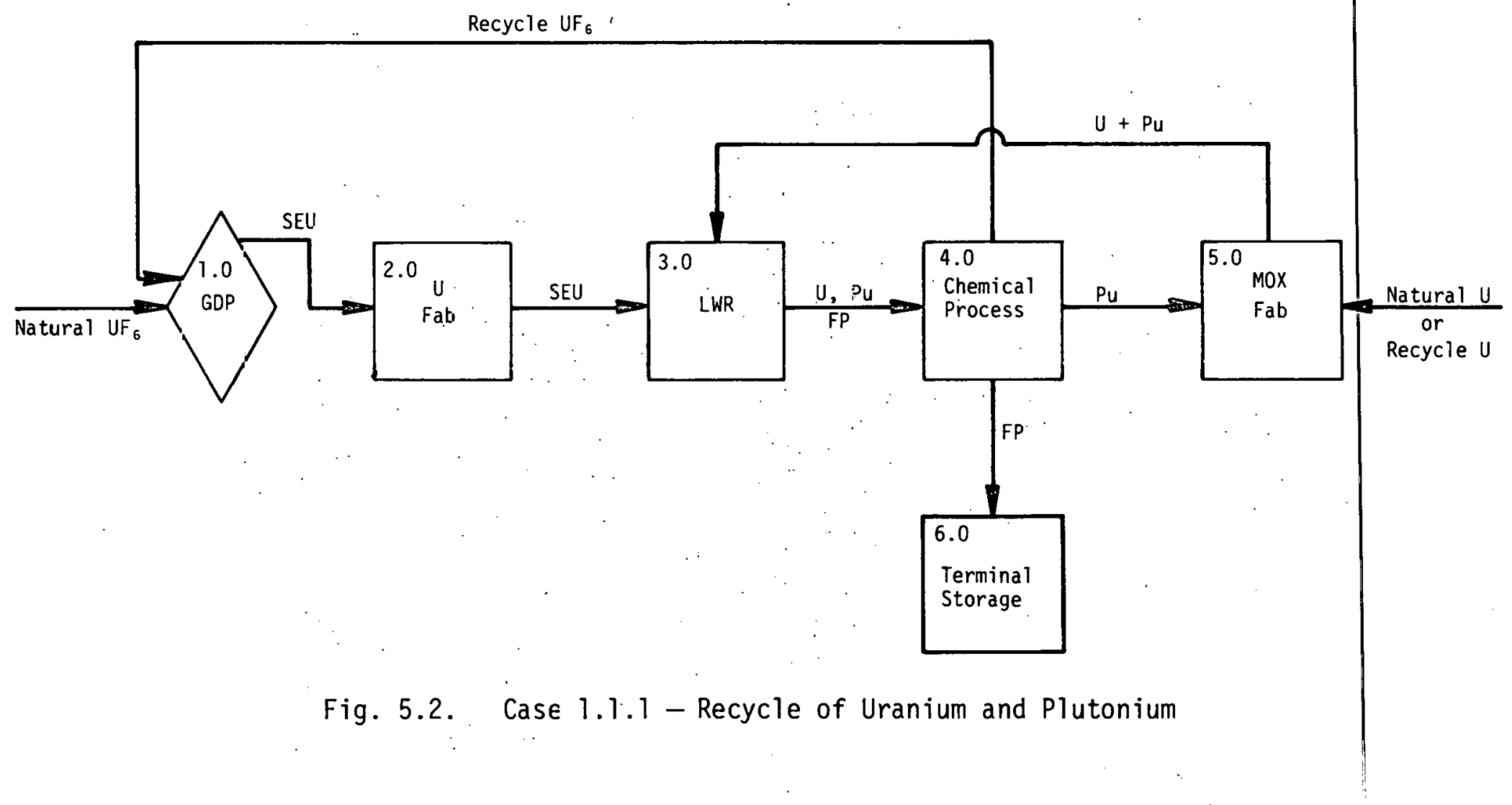


LEVEL 1

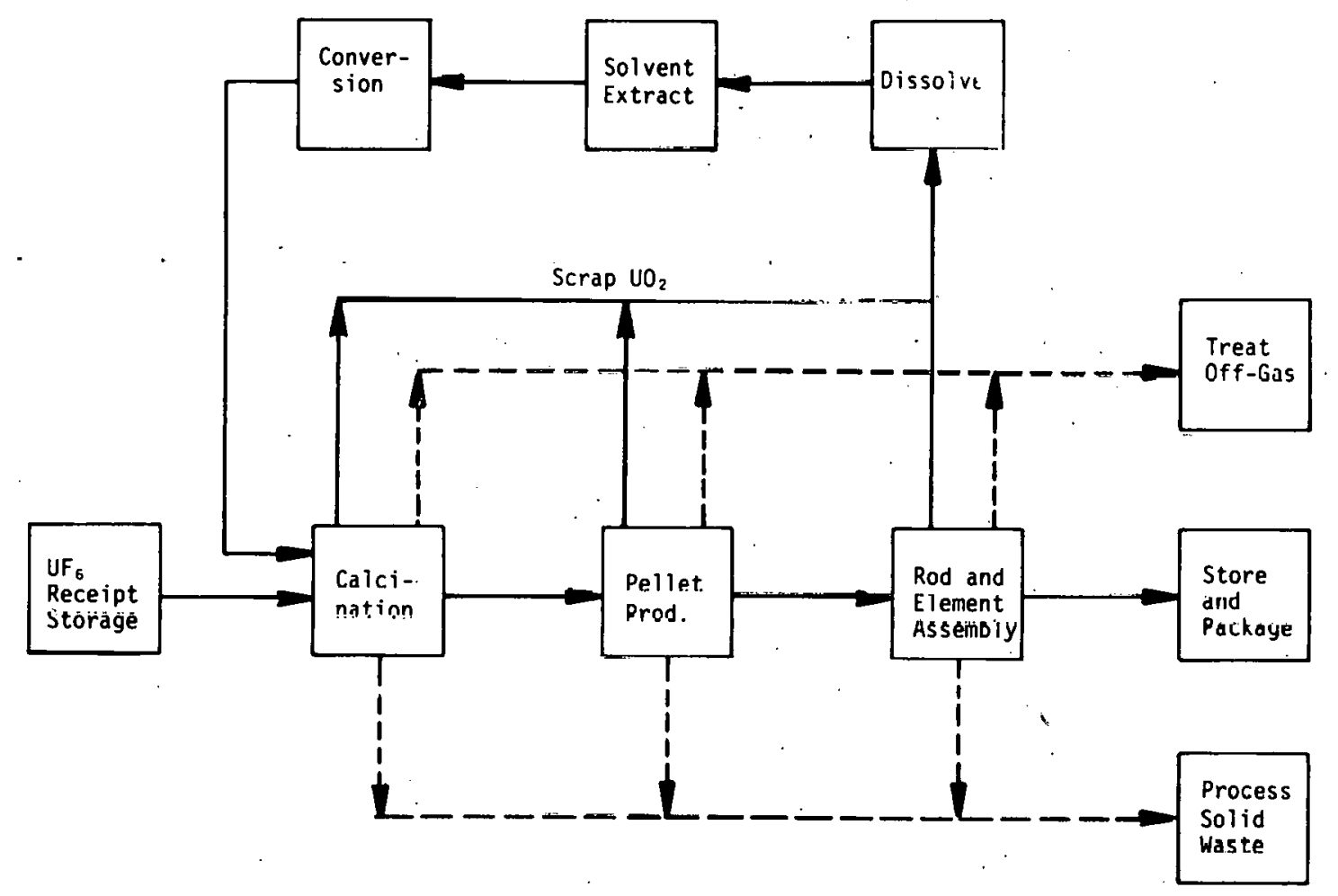

All functions are developed state of the art; material has negligible radiation level.

Material convertibility is Category B for all steps except

"Treat Off-Gas" and "Process Solid Waste."

Fig. 5.3. Case 1.1.1 - Recycle of Uranium and Plutonium; Slightly Enriched $(2-4 \%, 235 \mathrm{U})$ Uranium Fabrication (2.0) 
LEVEL 1

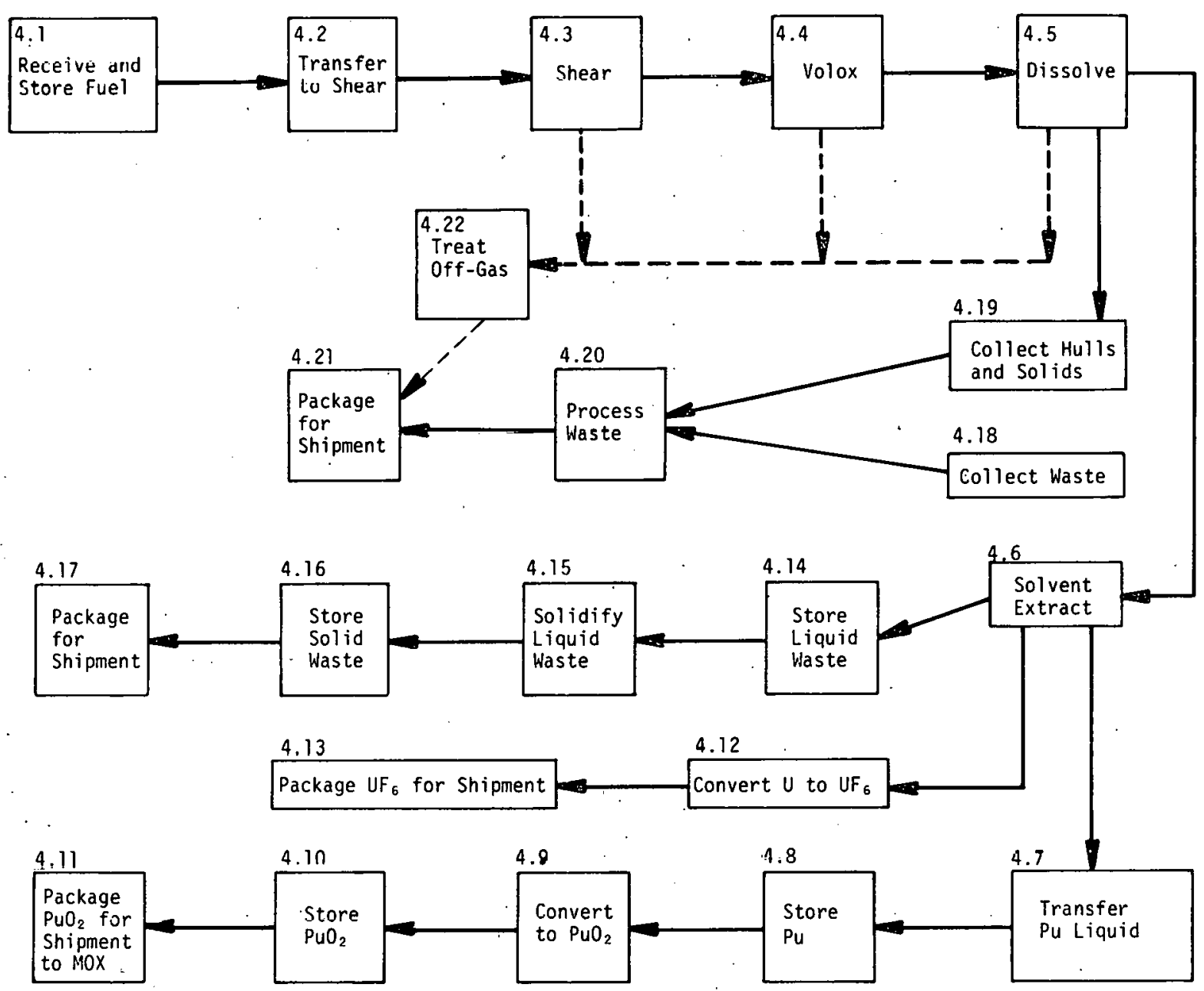

Fig. 5.4. Case 1.1.1 - Recycle of Uranium and Plutonium; Chemical Reprocessing (4.0) 
LEVEL 1

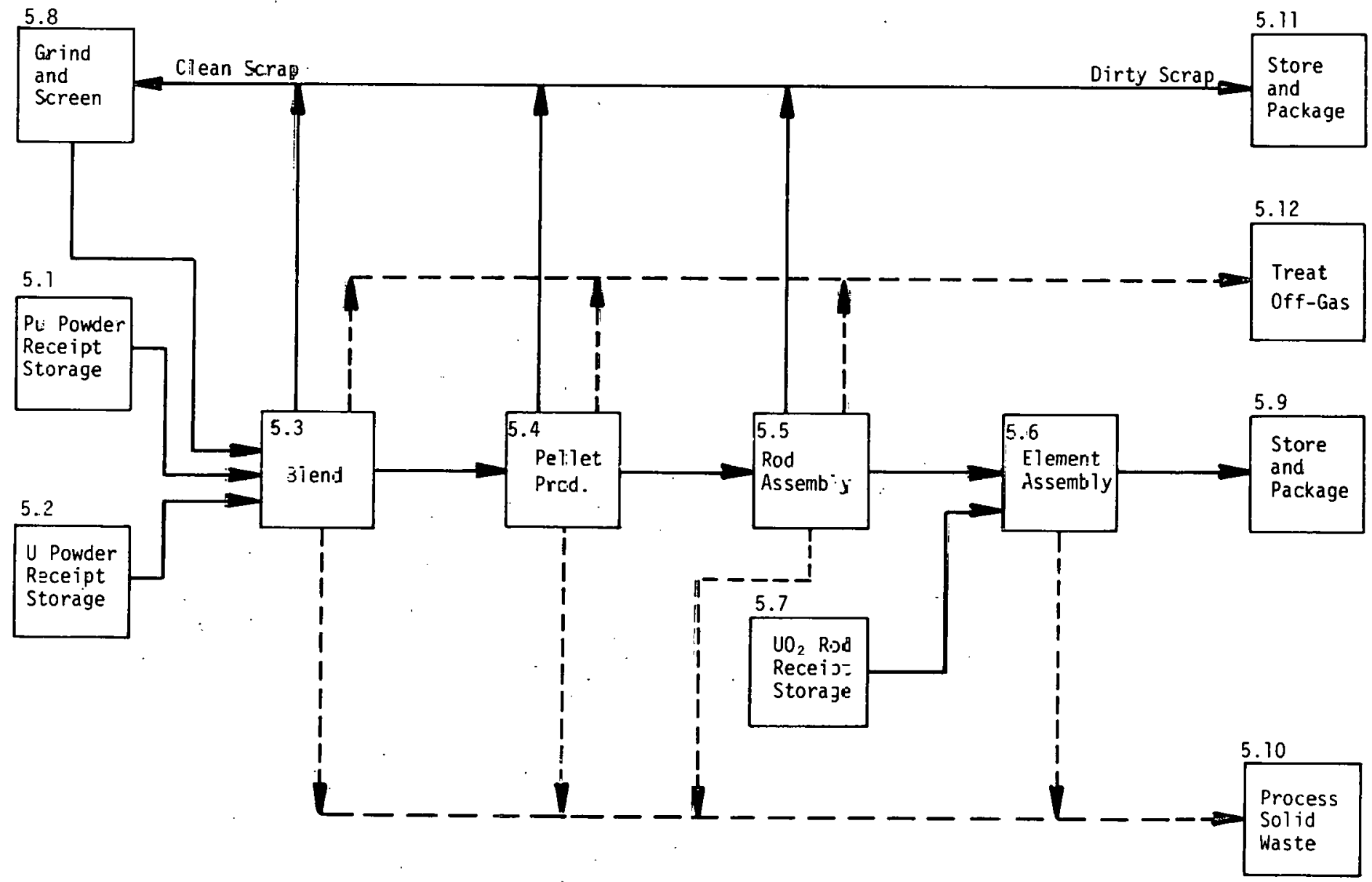

Fig. 5.5. Case 1.1.1 - Recycle of Uranium and Plutonium; MOX Fabrication (5.0) 
reprocessing step (4.0) and the MOX fabrication step (5.0) are shown in Table 5.2. This fuel cycle is probably the most well-defined and will be useful in the study as a reference cost case.

The MOX plant is assumed to be located at a separate site from the reprocessing plant (also in Cases 1.1.2, 1.1.3, and 1.1.7). A co-1ocated MOX plant could be another case for evaluation.

\subsubsection{Case 1.1.2 (LWR): Recycle of Uranium and Spiked Plutonium}

Level 0 segments are shown schematically in Figure 5.6; Level 1 steps, in Figures 5.7, 5.8, and 5.9. The state-of-the-art and material characteristics for the chemical reprocessing step (4.0) and refabrication step (5.0) are shown in Table 5.3.

Fission products in the plutonium may interfere with proven fabrication methods and quality control inspection of MOX fuel and thereby affect the fuel power guarantees that are customary for fuel fabricators to offer utilities.

The optimum amount of radiation to be emitted by the plutonium is a balance of the benefits gained in resistance to unauthorized use to the cost penalties in processing. Pending more study (see Section 5.4, "Spiking Plutonium"), the plutonium stream from the first Purex cycle of solvent extraction is assumed to contain the desired level of fission product content in the plutonium in Cases 1.1.2, 1.1.3, and 3.1.2. Radiation emitted will vary with fuel power, fuel decay period, chemical processing techniques, and other factors. 
KEY to Symbols in Tables 5.2 through 5.18

A. State of the Art (8 stages)
$S=$ Study Concept
$\mathrm{HE}=$ Hot Engineering
$\mathrm{CL}=$ Cold Laboratory
$\mathrm{CP}=$ Cold Prototype
HL - Hot Laboratory
HnF = Hot. Demonstration Facility
$\mathrm{CE}=$ Cold Engineering
$\mathrm{D}=$ Developed

B. Radiation Hazard (4 ranges)

$\begin{array}{ll}\text { High: } & >10^{4} \mathrm{R} / \mathrm{hr} \\ \text { Medium: } & 10 \text { to } 10^{4} \mathrm{R} / \mathrm{hr} \\ \text { Low: } & <10 \mathrm{R} / \mathrm{hr} \\ \text { Negligible: } & ₹ 100 \mathrm{mR} / \mathrm{hr}\end{array}$

C. Material Convertibility ( 4 classes of fissionable materia1)

$A=$ Matrial needs isotope separation for enrichment to weapons grade and is radioactive.

$B=$ Mat.erial needs isotope separation for enrichment to weapons grade.

$\mathrm{C}=$ Highly radioactive material mixed with fissionable material, but chemically separable.

$D=$ Minor impurities or minor chemical changes needed to convert to weapons-grade material. 
Table 5.2. Case 1.1.1 (LWR): Recycle of Iranium and Plutuniau (Roference Promesis)

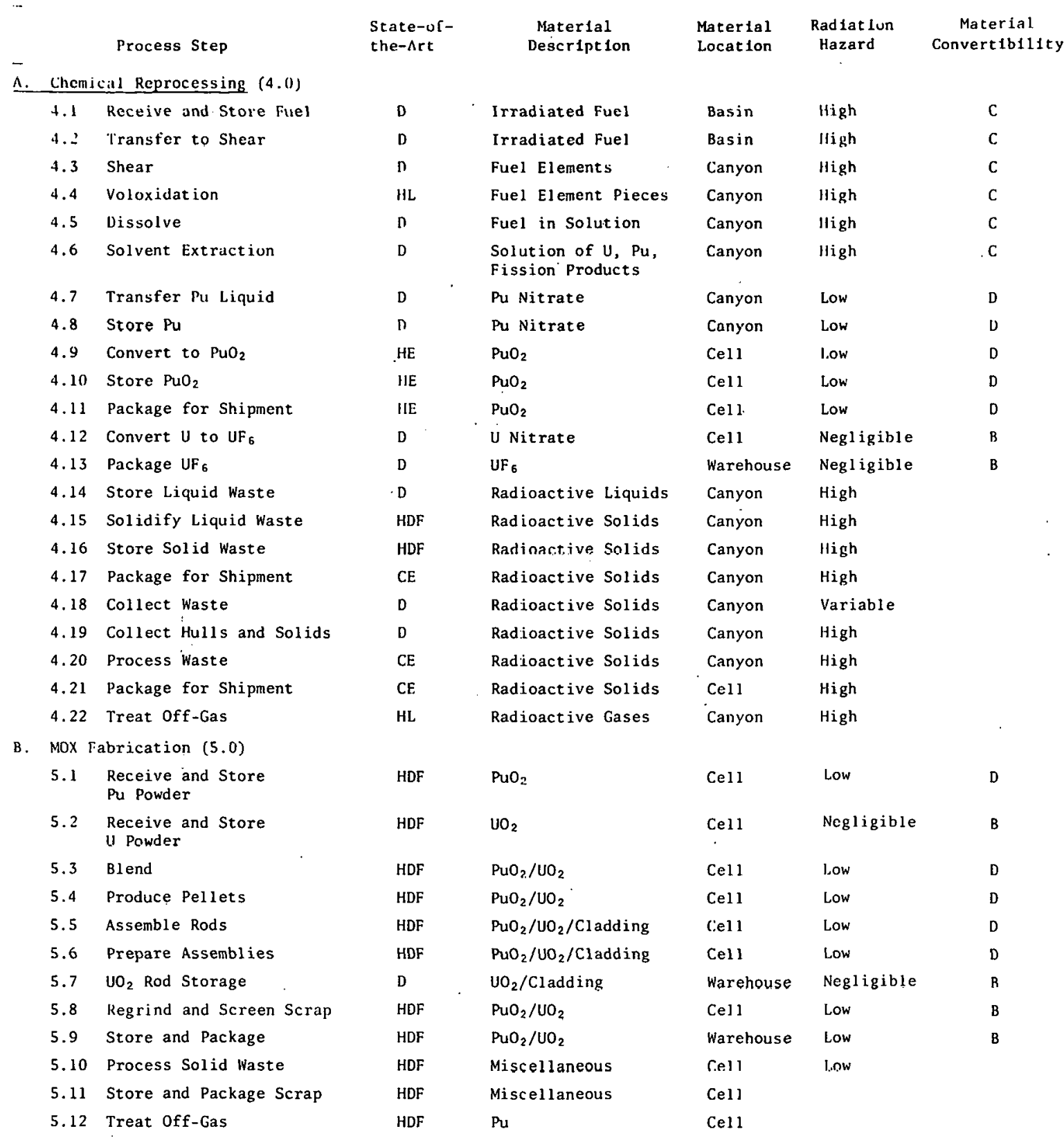


LEVEL 0

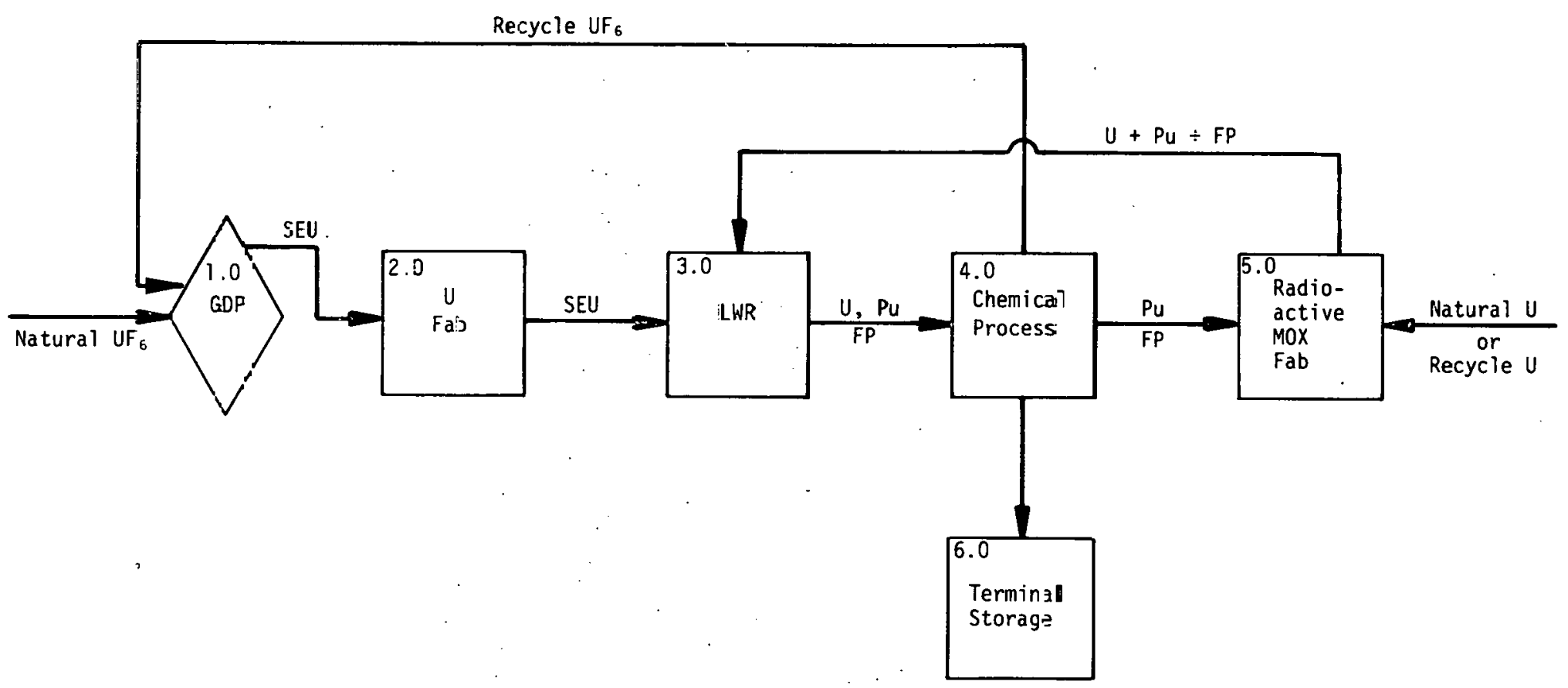

Fig. 5.6. Case 1.1.2 - Recycle of Uranium and Plutonium with Fission Products 
LEVEL 1

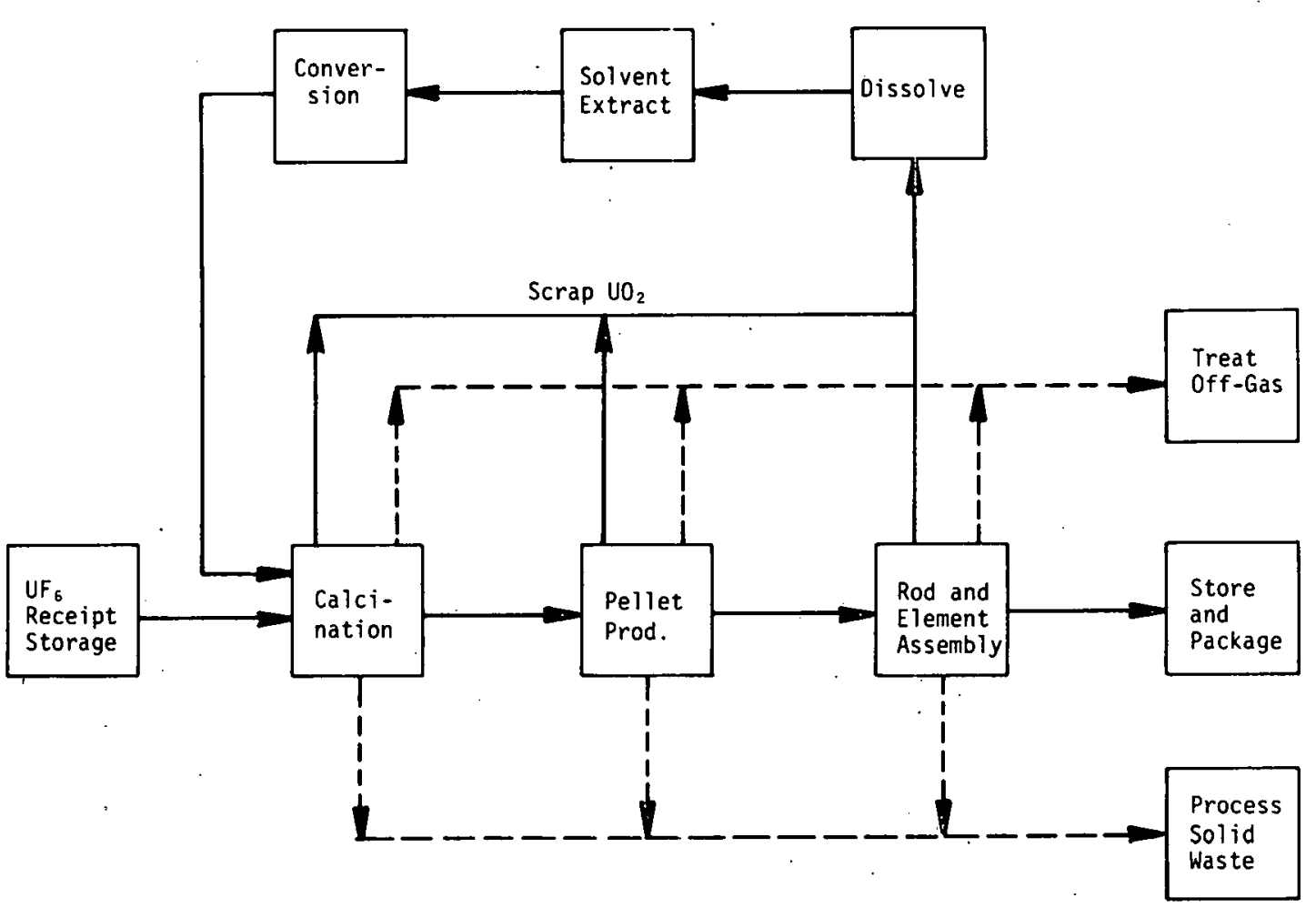

All functions are developed state of the art; material is a negligible radiation hazard. Material convertibility is Category B for all steps except "Treat Off-Gas" and "Process sol id Waste."

Fig. 5.7. Case 1.1.2 - Recycle of Uranium and Plutonium with Fission Products; Slightly Enriched (2-4\% $235 \mathrm{U}$ ) Uranium Fabrication (2.0) 
LEVEL ।

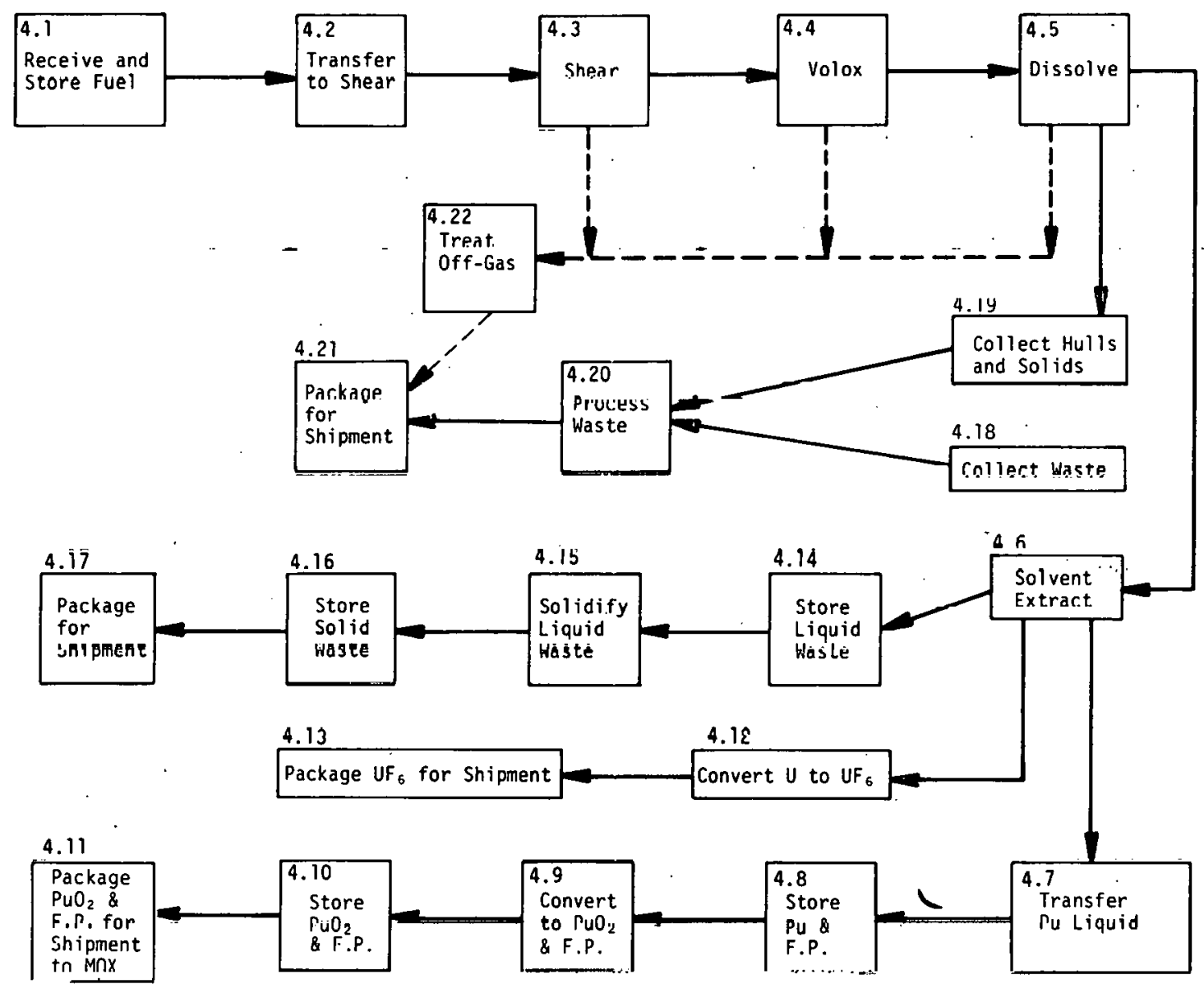

Fiy. 5.8. Làse 1.1.2 - Recycle of Uranium and Plutonium with Fission Products; Chemical Reprocessing (4.0) 
LEVEL 1

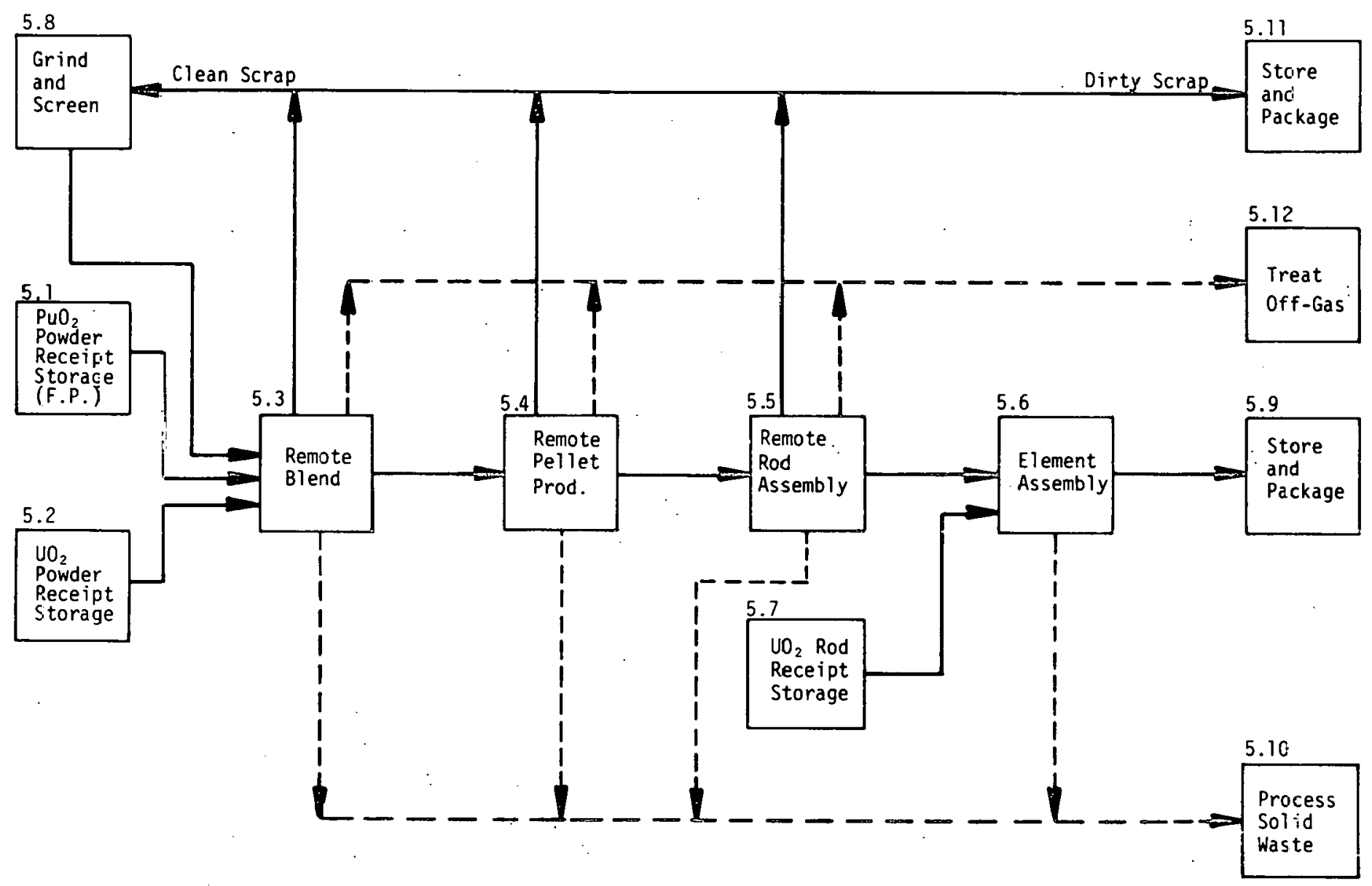

Fig. 5.9. Case 1.1.2 - Recycle of Uranium and Plutonium with Fission Products; MOX Fabrication (5.0) 
Table 5.3. Case 1.1.2 (LWR): Rerycle of Uranlum and Spiked Plutonium

\begin{tabular}{|c|c|c|c|c|c|c|c|}
\hline & & Process Step & $\begin{array}{l}\text { State-of- } \\
\text { the-Art }\end{array}$ & $\begin{array}{l}\text { Material } \\
\text { Description }\end{array}$ & $\begin{array}{l}\text { Material } \\
\text { Location }\end{array}$ & $\begin{array}{l}\text { Radiation } \\
\text { Hazard }\end{array}$ & $\begin{array}{c}\text { Material } \\
\text { Convertibility }\end{array}$ \\
\hline \multirow[t]{23}{*}{ A. } & Chemi & a 1 Reprocessing $(4.0)$ & $\cdot$ & & & & $\cdot$ \\
\hline & 4.1 & Receive and Store Fuel & $\mathbf{D}$ & I rradiated Fuel & Basin & $\mathrm{High}$ & C \\
\hline & +.2 & Transfer to Shear & D & Irradiated Fuel & Basin & $\mathrm{High}$ & $c$ \\
\hline & 4.3 & Shear & D & Fuel Elements & Canyon & $\mathrm{High}$ & C \\
\hline & 4.4 & Voloxidation & HL & Fuel Element Pieces & Canyon & Nigh & ¿ \\
\hline & 4.5 & Missolve & D & Fuel in Solution & Canyon & High & c: \\
\hline & 4.6 & Solvent Extraction & D & $\begin{array}{l}\text { Solution of } U_{;} P u, \\
\text { Fission Products }\end{array}$ & Canyon & $\mathrm{Hi}$ gh & $i$ \\
\hline & $4 .=$ & Transter Pu Liquid & $\mathbf{C P}$ & Pu Nitrate, Fission Prod. & Canyon & Medium & c. \\
\hline & 4.8 & Store Pu & $\mathrm{CP}$ & Pu Vitrate, Fission Prod. & Canyon & Medium & $\mathrm{c}$ \\
\hline & 1.9 & Convert to $\mathrm{PuO}_{2}$ & $C P$ & $\mathrm{PuO}_{2}$, fission Frod. & Ce 1.1 & Mcdium & $\dot{c}$ \\
\hline & 4.10 & Store $\bar{P}_{10}$ & $\mathrm{CP}$ & $\mathrm{HuU}_{2}, \mathrm{Fission}$ Prōd. & Lèll & Meoium & ᄂ \\
\hline & +.11 & Pacliage for Shipment & $\mathrm{Cp}$ & $\mathrm{PuO}_{2}, \mathrm{Hission}$ Irod. & léll & Medium & ¿: \\
\hline & +.12 & Comvert $\mathrm{U}$ to $\mathrm{UF}_{6}$ & D & U Nitrate & Cell & Negligible & B \\
\hline & 4.13 & Package $U F_{6}$ & D & $\mathrm{UF}_{6}$ & Narehouse & Negligible & B \\
\hline & 4.14 & Store Liquid Waste & 0 & Radioacrive Liquids & Canyon & High & \\
\hline & 4.15 & Sulidily Liquid Waste & IIDF & Radioactive Solids' & Canyon & High & \\
\hline & +.16 & Store Solid Waste & HDF & Radioactive Solids & Canyon & High & \\
\hline & $+.1^{\prime \prime}$ & Hackage for shipment & CE & Radioactive Solids & Canyon & lligh & \\
\hline & 4.18 & Collect Waste & D & Radioactive Solids & Canyon & l'ariable & \\
\hline & +19 & rnllert Hulls and Snlids & D & Radioactive Solids & Canyon & High & \\
\hline &.$+ \vdots 10$ & Piuless Hasie & $\mathrm{CL}$ & Radiualion Solids & Canjon & lligh & \\
\hline & 4.21 & Package for Shipment & CE & Radioactive Solids & Ce11 & $\mathrm{High}$ & \\
\hline & .13 & Treat nffagas & HI. & Radioactive Gases & Canyon & High & \\
\hline B. & \multicolumn{7}{|c|}{ Yox Fabrication $(5.0)$} \\
\hline & 3.1 & $\begin{array}{l}\text { Reecive and Store } \\
\text { Pu Powder }\end{array}$ & cl & $\mathrm{PuO}_{2} / \mathrm{F} . \mathrm{F}$ & Coll & Medium & C \\
\hline & 5.2 & $\begin{array}{l}\text { Receive and Store } \\
\text { U Powder }\end{array}$ & HDF & $\mathrm{NO}_{2}$ & Cell & Vegligible & B \\
\hline & 5.5 & Blend & $\mathrm{CP}$ & $\mathrm{PuO}_{2} / \mathrm{UO}_{2} /$ F.P. & Cell & ledium & c \\
\hline & 5.4 & Plüduce Pellets & $C P$ & $\mathrm{PuO}_{2} / \mathrm{UO}_{2} / \mathrm{F} . \Gamma$ & $\mathrm{CeII}$ & Medium & c \\
\hline & 5.5 & Assemble Rods & $\mathrm{CP}$ & $\mathrm{PuO}_{2} / \mathrm{UO}_{2} / \mathrm{Cladd}$ ing/F:P. & Cell & Medium & c \\
\hline & 5.0 & Prepare Assemblies & $\mathrm{CP}$ & $\mathrm{PuO}_{2} / \mathrm{UO}_{2} / \mathrm{Cladding} / \mathrm{F} . \mathrm{P}$. & Cell & Medium & $c$ \\
\hline & 5.7 & Ine Rnd Starage & $C P$ & $\operatorname{IIn} n_{2} /$ C.1 ardd ing & Cell & Vegligible & B \\
\hline & 5.8 & Regrind and Screen Scrap & $\mathrm{CP}$ & $\mathrm{PuO}_{2} / \mathrm{UO}_{2} /$ F.P. & Cell & Medium & c \\
\hline & 3.9 & Sicule allu Pathage & $\mathrm{CF}$ & $\mathrm{PuO}_{2} / \mathrm{UO}_{2} / \Gamma . \Gamma$ & $\mathrm{Cell}$ & Medium & c \\
\hline & 5.10 & Process Solid Waste & HDF & Miscellaneous & Cell & $\cdot$ & \\
\hline & 5.11 & Store and Package Scrap & HUF & Miscellaneous & Cell & & \\
\hline & 5.12 & Treat oft-Gas & HDF & $\mathrm{Pu}$ & Cell & & \\
\hline
\end{tabular}




\subsubsection{Case 1.1.3 (LWR): Recycle of Uranium and Spiked Uranium - Plutonium Oxide (Coprocessed)}

Level 0 segments are shown schematically in Figure 5.10; Leve1 1 steps, in Figures 5.11, 5.12, and 5.13. The state-of-the-art and material characteristics for the chemical processing step (4.0) and the MOX fabrication step (5.0) are shown in Table 5.4.

The coprocessed product is about $10 \% \mathrm{Pu}-90 \% \mathrm{U}$ with excess uranium separated and converted to $\mathrm{UF}_{6}$. The fission product content is assumed to vary as previously discussed. See also the section "Spiking Plutonium."

\subsubsection{Case 1.1.4 (LWR): Recycle of Uranium (Plutonium Diverted to High Activity Waste Stream)}

Leve1 0 segments are shown schematically in Figure 5.14; Level 1 steps, in Figures 5.15 and 5.16. The state-of-the-art and material description for the chemical reprocessing step (4.0) are shown in Table 5.5.

This fuel cycle complicates the waste processing steps and yields none of the economic benefit from plutonium recycle as in Reference Case 1.1 .1 .

\subsubsection{Case 1.1.5 (LWR): Fuel Throwaway - Oxide Fuel}

Level 0 segments are shown schematically in Figure 5.17; Level 1 steps, in Figures 5.18 and 5.19. The state-of-the art and material characteristics for the major processing steps are shown in Table 5.6.

A portion of this fuel cycle is the current mode of LWR operation in the U.S. and thus is a present-day reference similar to Case 1.1.1. Irradiated fuel is currently being stored at LWR sites in the U.S. ERDA has programs to define the away-from-reactor storage systems and the terminal waste disposal systems for irradiated LWR fuel.

\subsubsection{Case 1.1.6 (IWR): Fue1 Throwaway = Metal Fuel}

Leve1 0 segments are shown schematically in Figure 5.20; Level 1 steps, in Figures 5.21 and 5.22. The state-of-the-art and material characteristics for the fuel encapsulation steps (8.0) are shown in Table 5.7.

The process description is similar to Case 1.1 .5 , except that no metal fuel fabrication industry exists. Uranium metal fuel for LWR's would 
LEVEL 0

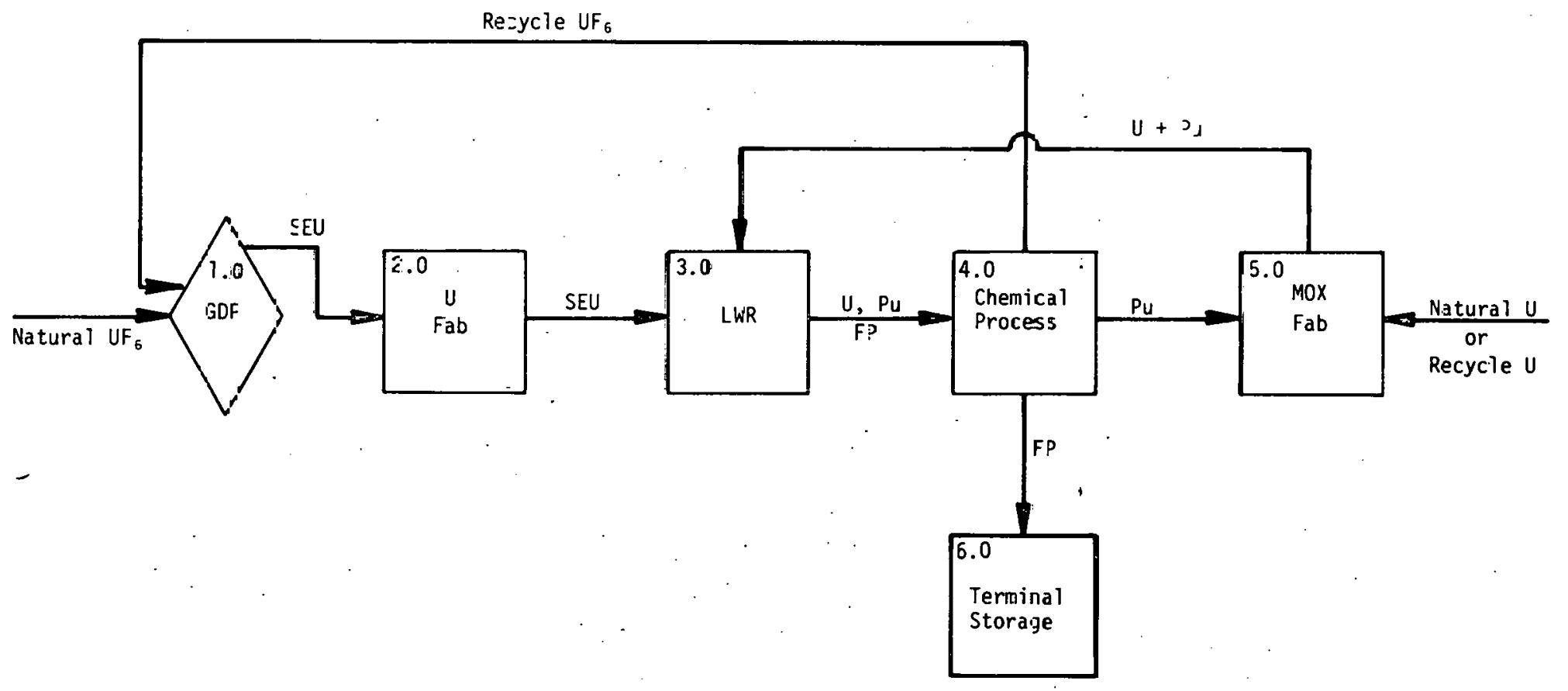

Fig. 5.10. Case i.1.3-Recicle of Uranium and Spiked Uranium-Plutonium Oxide (Coprocessed) 


\section{LEVEL 1}

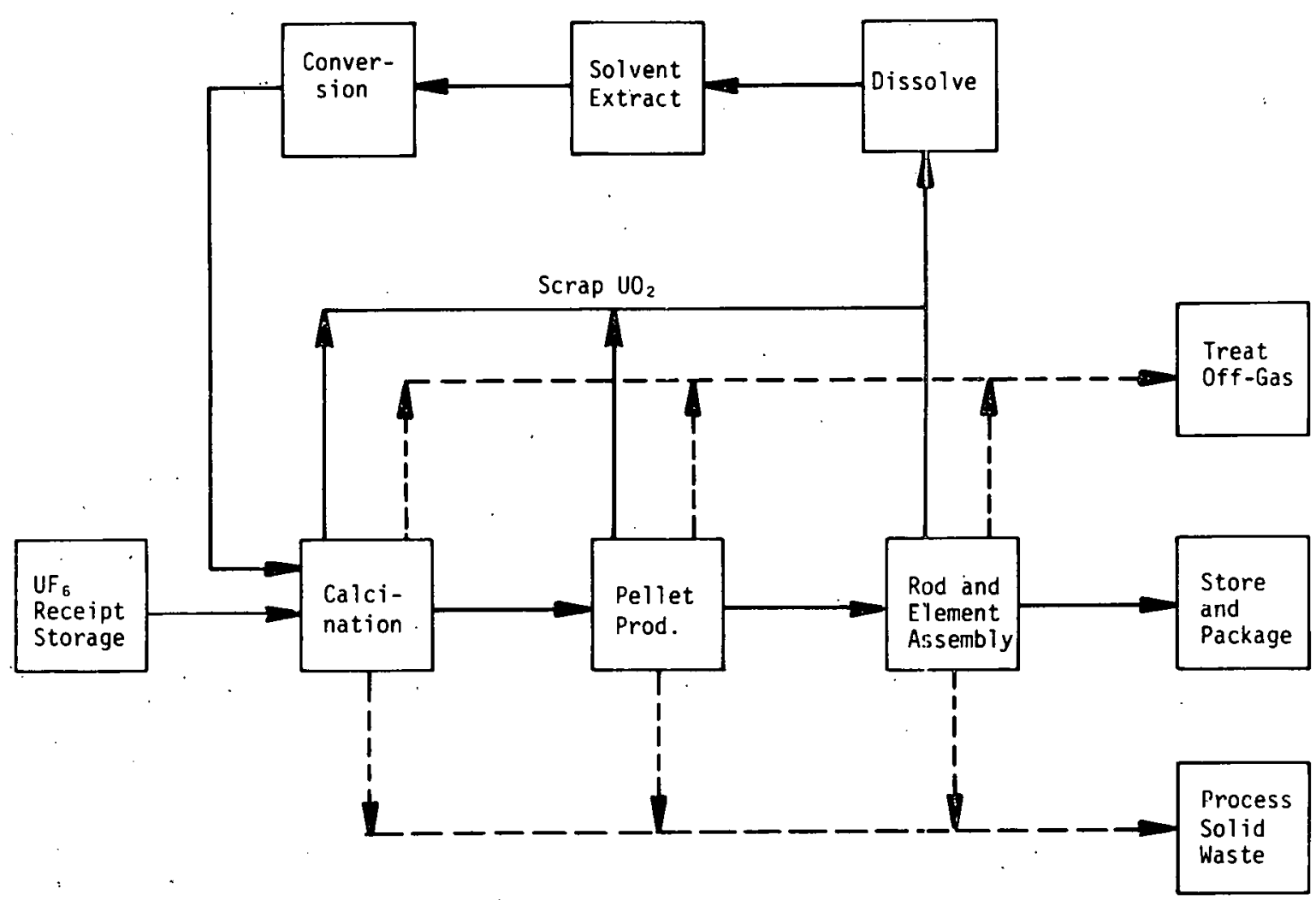

All functions are developed state of the art; material is a negligible radialiun hacard.

Material convertibility is Category $B$ for all steps except "Treat Off-Gas" and "Process Sol id Waste."

Fig. 5.11. Case 1.1.3 - Recycle of Uranium and Spiked Uranium-Plutonium Oxide (Coprocessed); Slightly Enriched (2-4\% $235 \mathrm{U})$ Uranium Fabrication (2.0) 
LEVEL 1

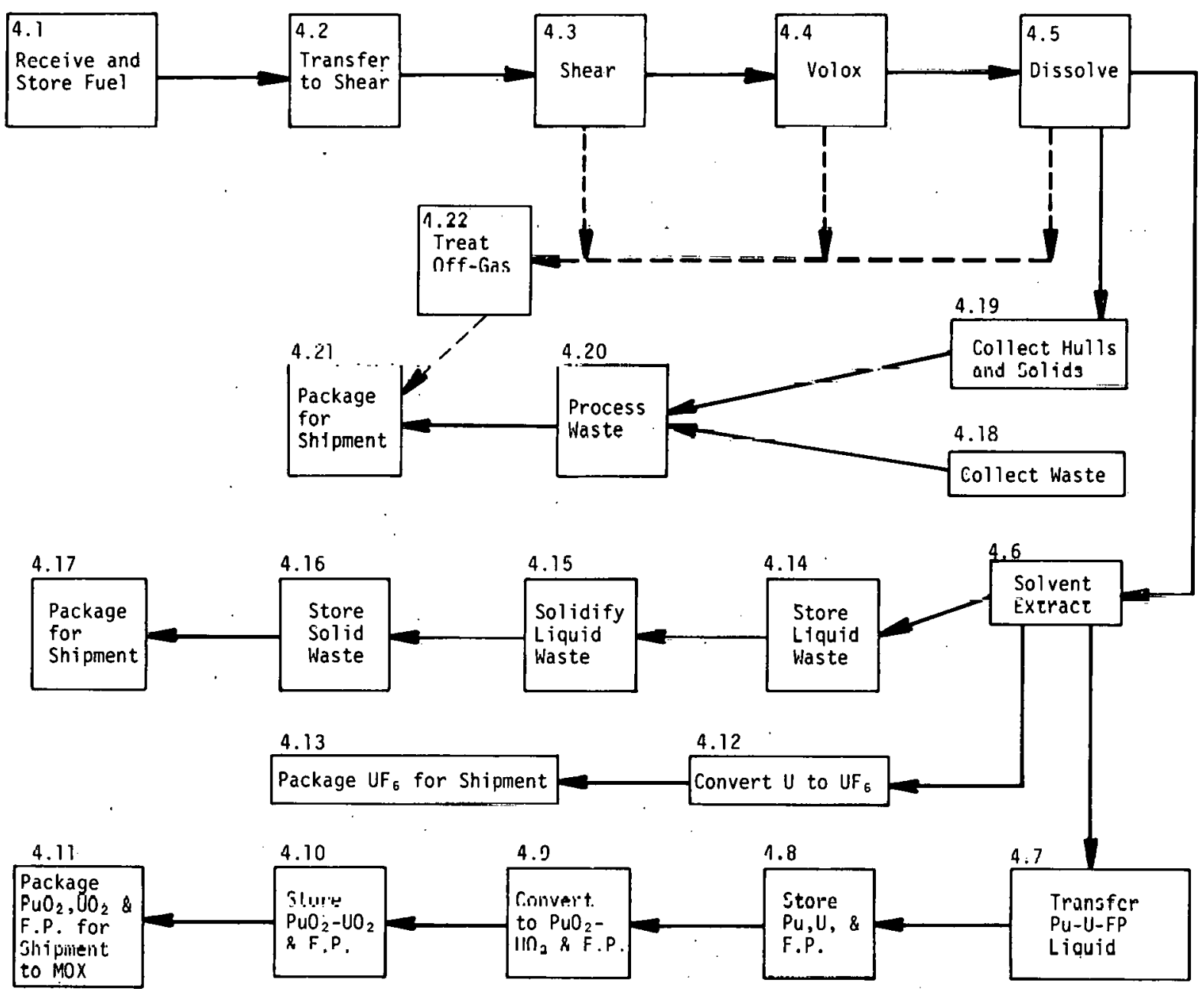

Fig. 5.12 Case 1.1.3 - Recycle of Uranium and Spiked Uranium - Plutonium Oxide (Coprocessed); Chemical Reprocessing (4.0) 
LEVEL 1

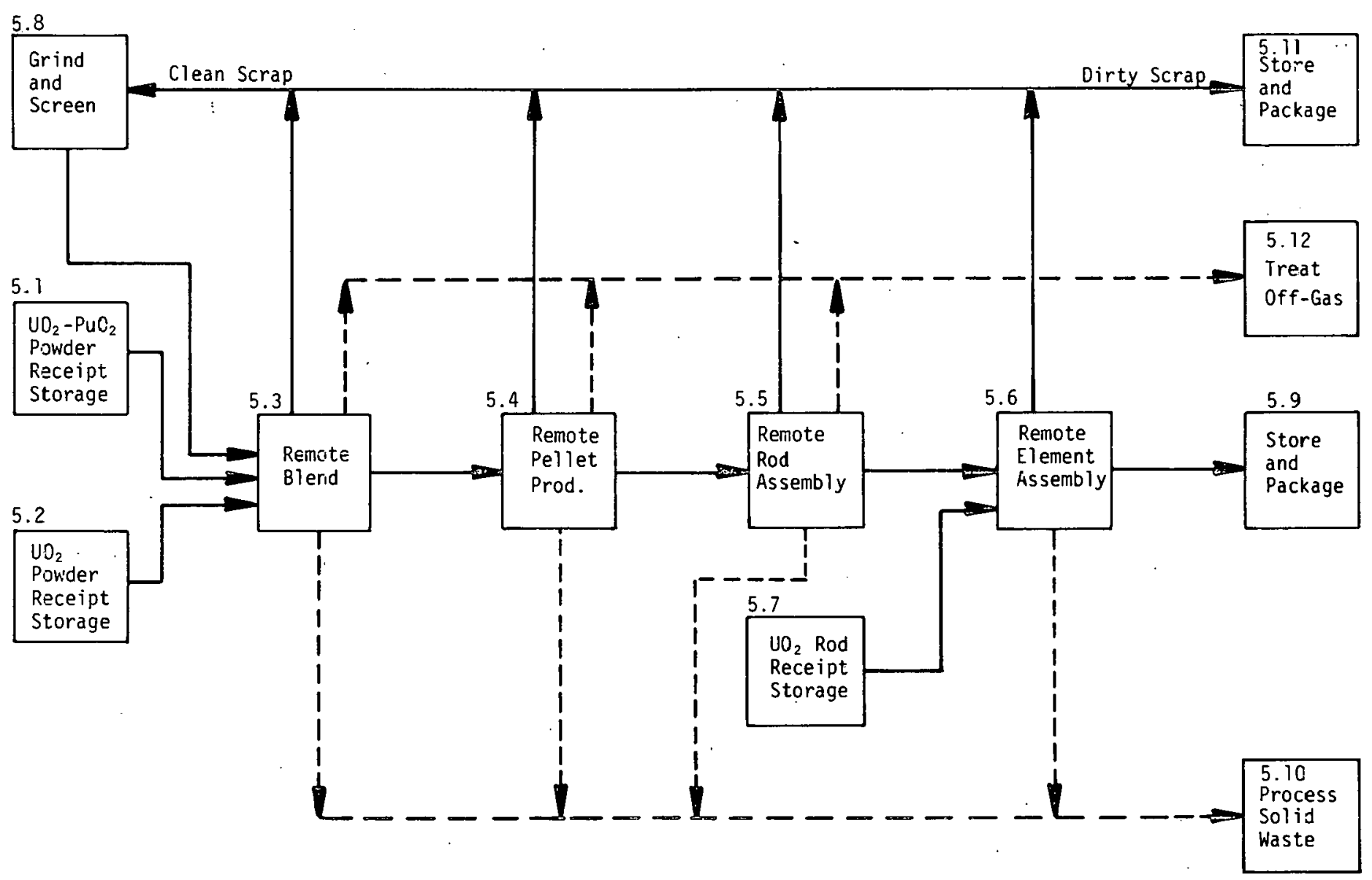

Fig. 5.13. Case 1.1.3 - Recycle of Uranium and Spiked Uranium-Plutonium 0xide (Coprocessed); MOX Fabrication (5.0) 
Tlable 5.4. (ase 1.1.3 (I.WR): Recycle of Uraniun and Spiked Uranium-Plutonium Oxide (Coprocessed)

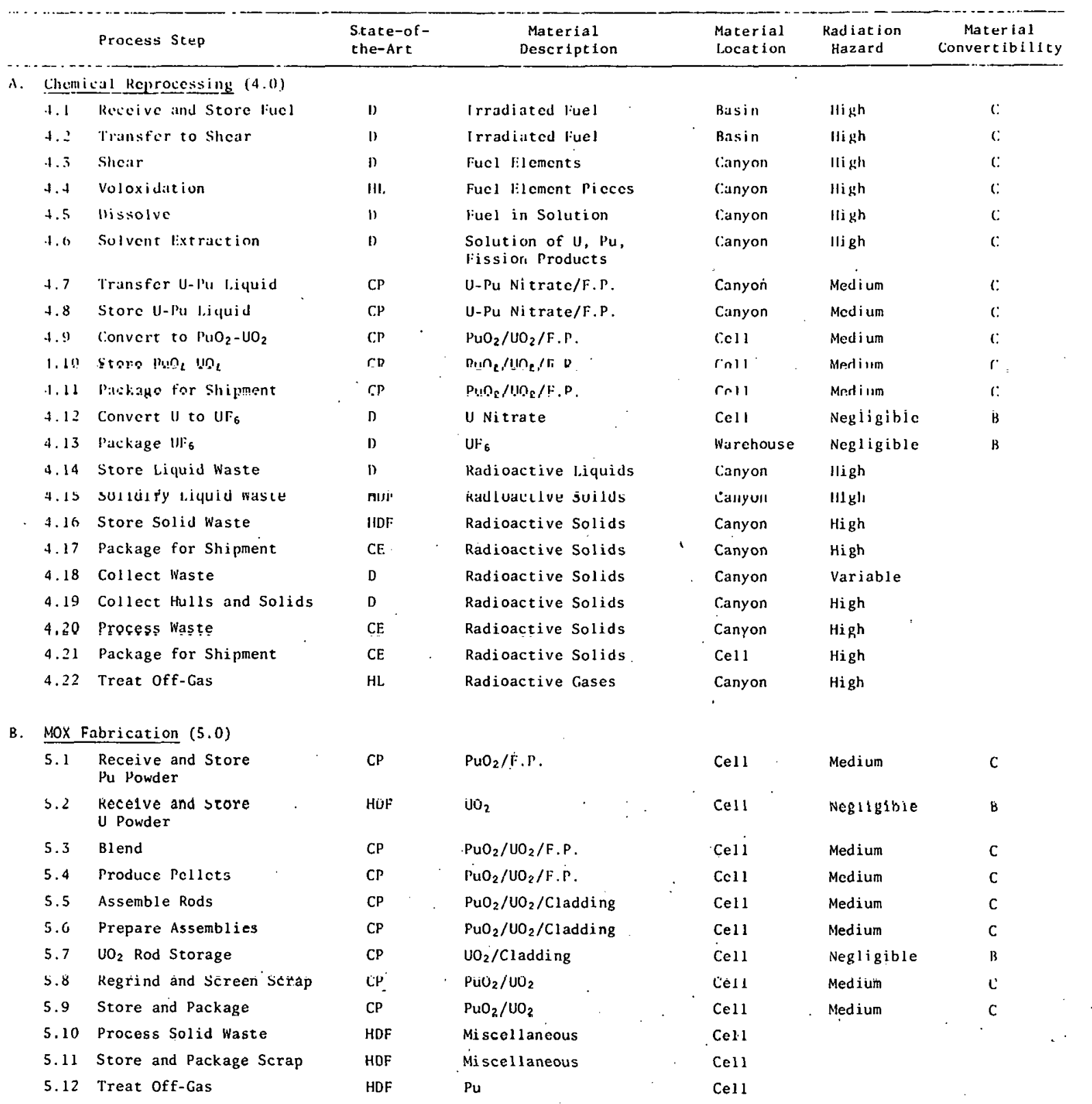


LEVEL 0

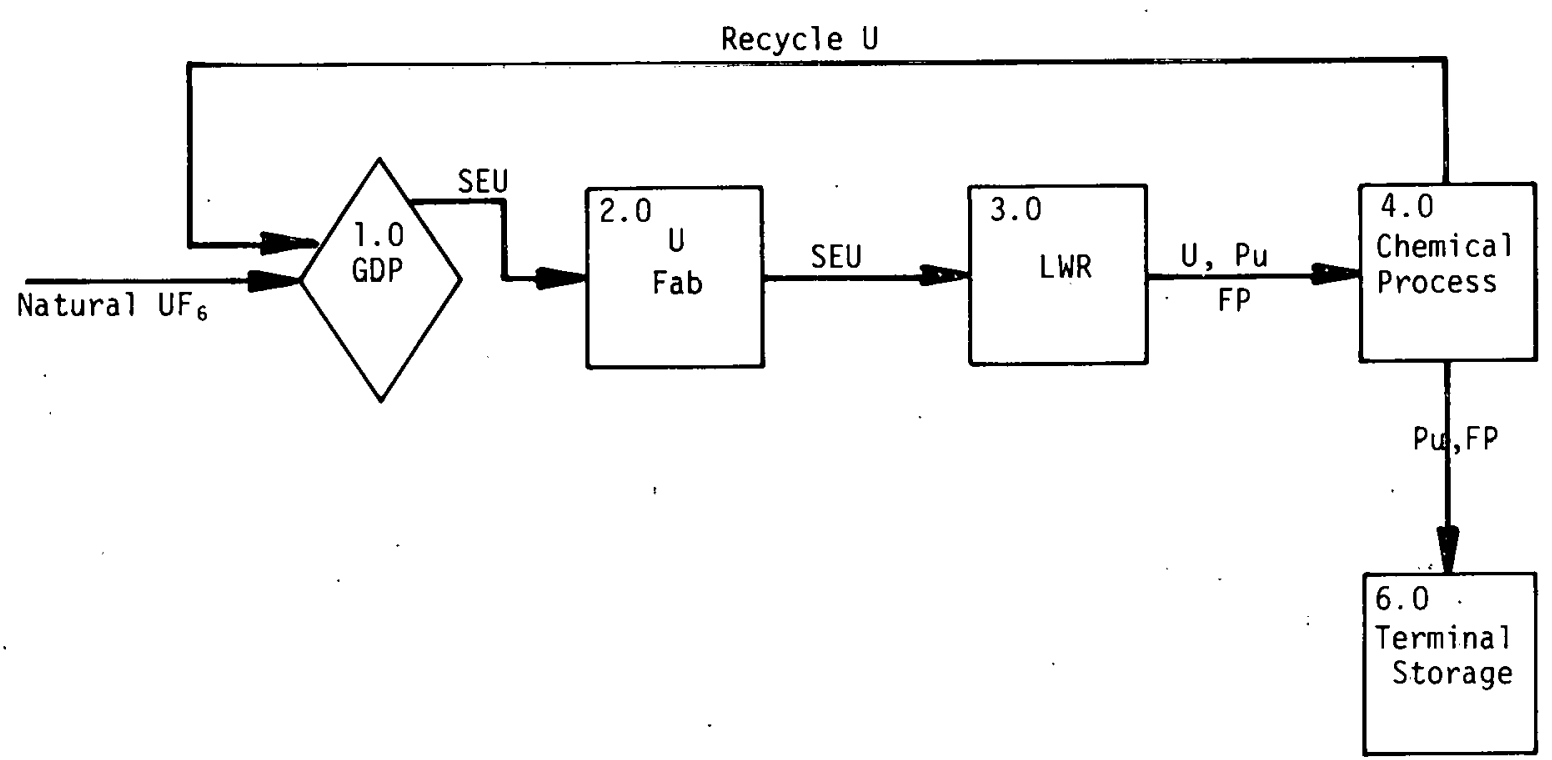

Fig. 5.14. Case 1.1.4 - Recycle of Uranium (Diversion of Plutonium to HAW Stream) 


\section{LEVEL 1}

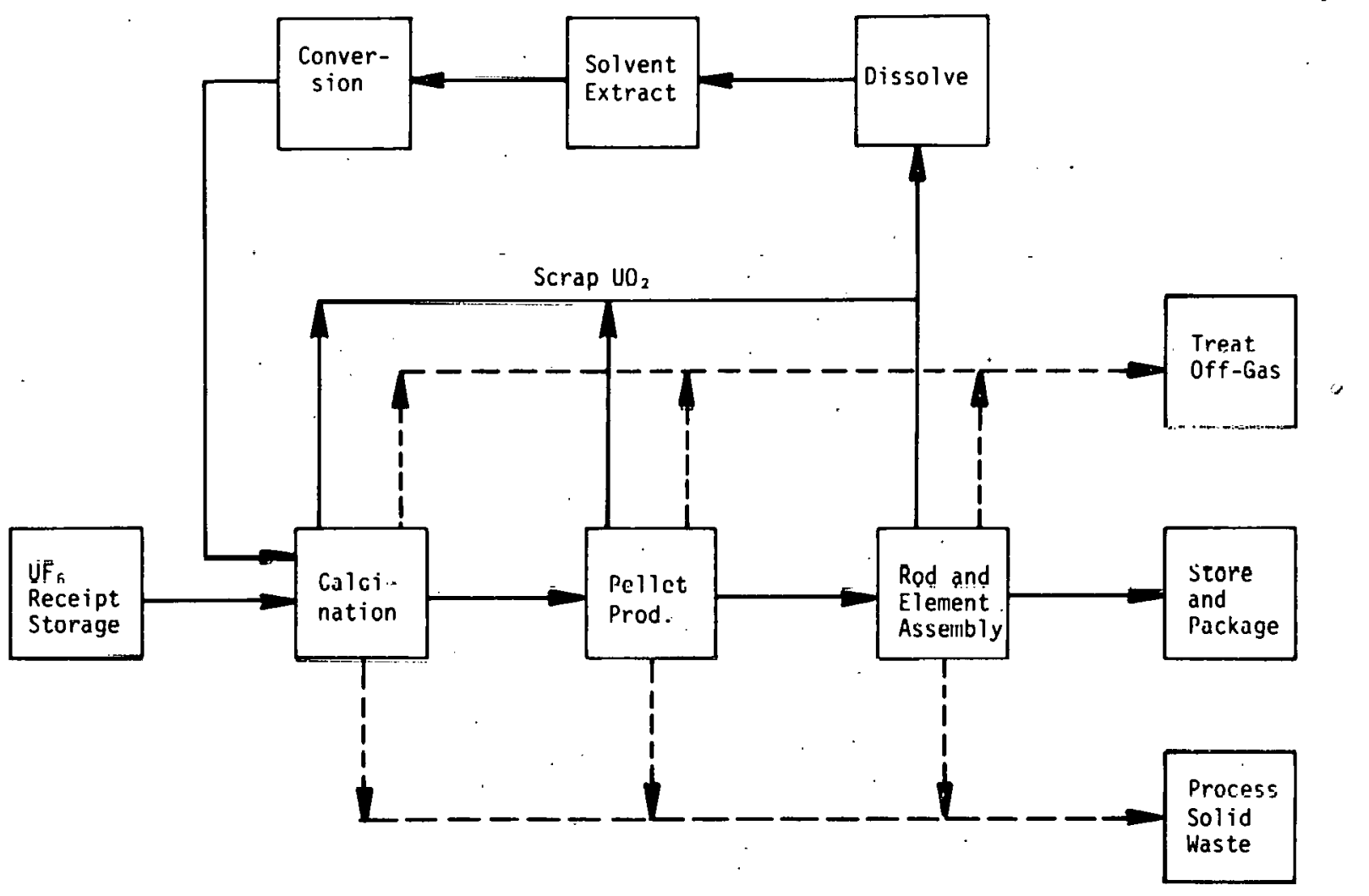

All functions are developed state of the art; material is a negligible radiation hazard.

Material convertibility is Catcgopy B for all steps except "Treat Off-Gas" and "Process Sol id Waste."

Fig. 5.15. Case 1.1.4-Recycle of Uranium (Diversion of Plutonium to HAW Stream); 31 ightly Enriched $(2-4 \% 235 \mathrm{U})$ Uranium Fabrication (2.0) 
LEVEL 1

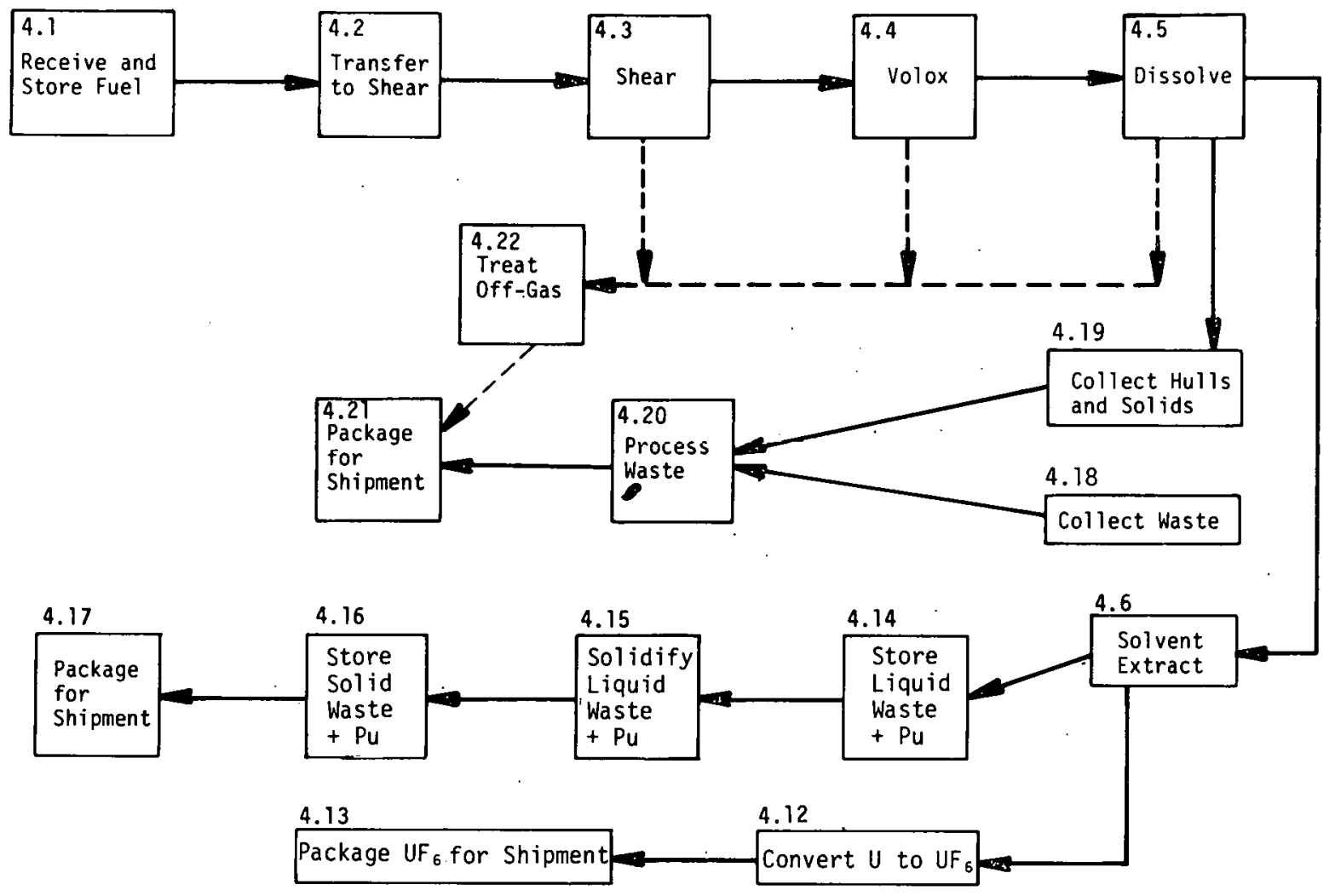

Fig. 5.16. Case 1.1.4 - Recycle of Uranium (Diversion of Plutonium to HAW Stream); Chemical Reprocessing (4.0) 
Table 5.5. Case 1.1.4 (I.WR): Recycle of Uranium (Plutonium Diverted to Waste)

\begin{tabular}{|c|c|c|c|c|c|c|}
\hline & Process Step & $\begin{array}{l}\text { State-of- } \\
\text { the Art }\end{array}$ & $\begin{array}{l}\text { Material } \\
\text { Description }\end{array}$ & $\begin{array}{l}\text { Material } \\
\text { Location }\end{array}$ & $\begin{array}{c}\text { Radiation } \\
\text { Hazard }\end{array}$ & $\begin{array}{c}\text { Material } \\
\text { Convertibility }\end{array}$ \\
\hline \multicolumn{7}{|c|}{ (hemicill Rejrocessing $(4.0)$} \\
\hline+.1 & Receive and Store Fuel & 0 & I rradiated fuel & Basin & High & i: \\
\hline 4.2 & Trunster to Shear & D. & Irradiated Fuel & Basin & IIigh & i: \\
\hline+.3 & Shear & b & luel Flements & Canyon & High & i: \\
\hline 1.4 & Voloxidation & HII. & Fuel Element Pieces & Canyon & Iligh & $c$ \\
\hline 4.5 & llissolve & $\mathrm{v}$ & Fuel in Solution & Canyon & Iligh & c: \\
\hline 4.6 & Solvent lixtraction & n & $\begin{array}{l}\text { Solution of } \mathrm{U}, \mathrm{Pu}, \\
\text { Fission Products }\end{array}$ & Canyon & lligh & c: \\
\hline 4.12 & Convert $\mathrm{U}$ to $\mathrm{UF}_{6}$ & 0 & U Nitrate & Cell & Negligiblo & $B$ \\
\hline 4.15 & Package UF 6 & 1) & $\mathrm{UF}_{6}$ & Warehouse & Negligible & $B$ \\
\hline 4.14 & Store Liquid Wastc & [) & Radioactive Liquids/Pu & Canyon & lligh & i: \\
\hline $1.1,5$ & Snlidify l,iuguid Waste & HDF & Kadioactive Solids/Pu & Canyon & $\mathrm{H} 1 \mathrm{gh}$ & c \\
\hline 116 & Store Solid Waste & HDF & Radioactive Solids/Pu & Canyon & Hi gh & $\mathrm{C}$ \\
\hline 4.17 & Package for Shipment & $\mathrm{CE}$ & Radioactivo Solidr/Pu & Canyon & II gh & $\mathrm{C}$ \\
\hline+.18 & Collect Waste & D & Radioactive Solids & Canyon & Variable & \\
\hline 4.19 & Collect Hulls and Solids & D & Radioactive Solids & Canyon & $\mathrm{High}$ & \\
\hline 4.20 & Pucess Wasto & $\mathrm{CF}$ & Radioactive \$olids & Cányon & Hi ght & \\
\hline+.21 & Package for Shipment & CE & Radioactive Solids & Ceil & Higlı & \\
\hline+.22 & Treat off-Gas & HL & Radioactive Gases & Canyon & $\mathrm{High}$ & \\
\hline
\end{tabular}


LEVEL 0

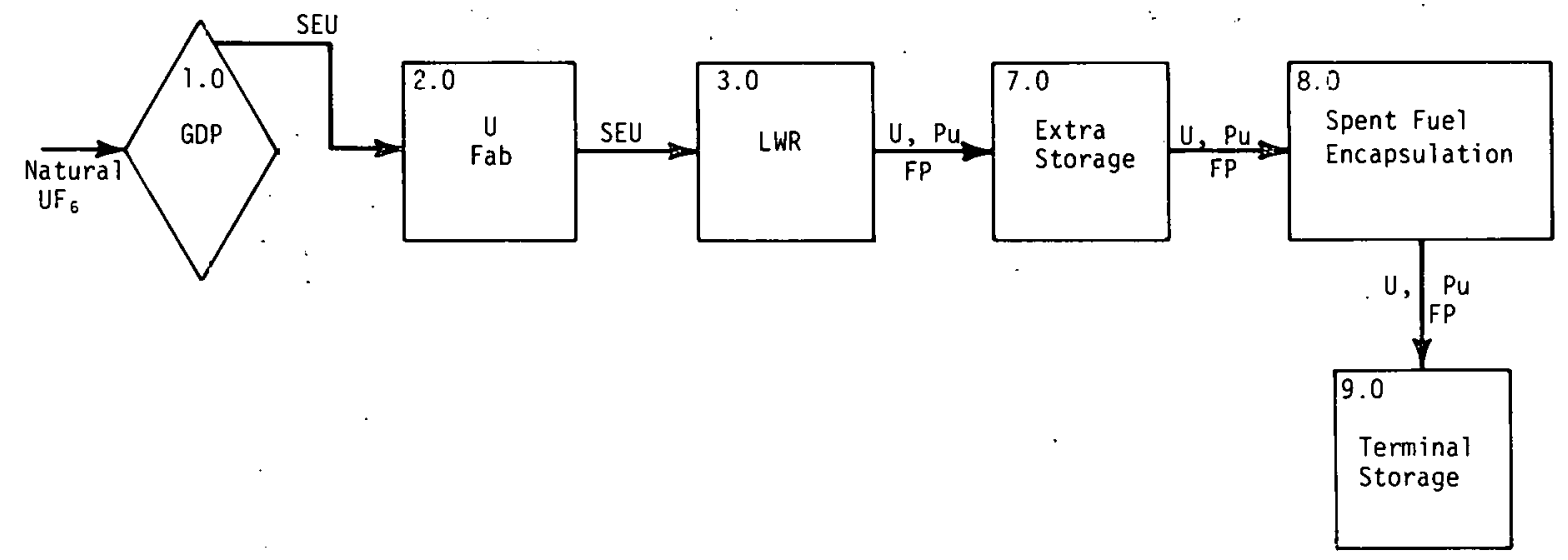

Fig. 5.17. Case 1.1.5 - Fuel Throwaway (Oxide Fuel) 


\section{LEVEL 1}

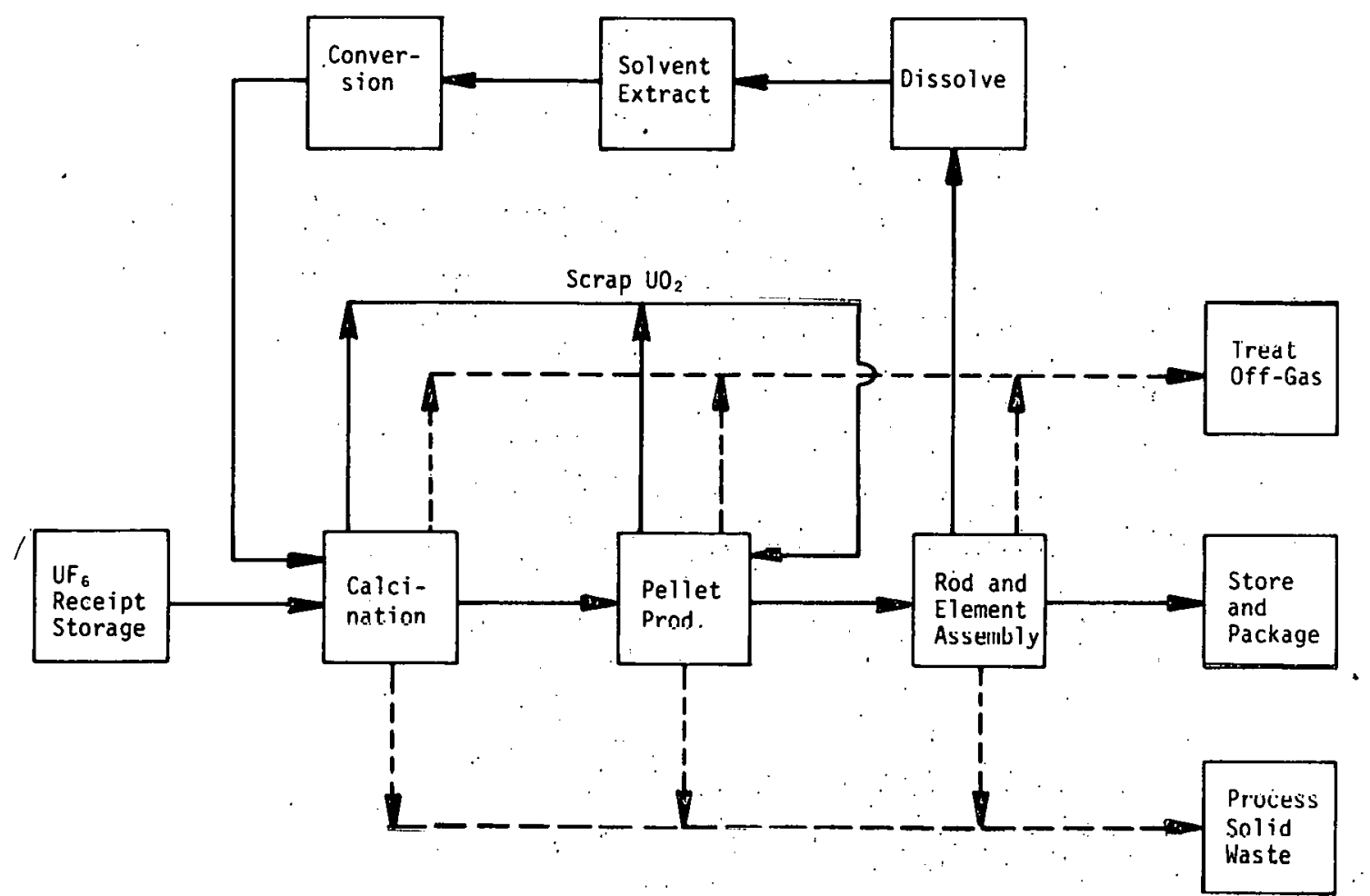

All functions are developed state of the ariz matertal is d Heyligible radiation nazard.

Material convertibility is Category B for all steps except "Treat Off-Gas" and "Process Solid Waste."

Fig. 5.18. Case 1.1.5 - Fuel Throwaway (Oxide Fuel); Slightly Enriched $\left(2-4 \%^{2}{ }^{5} \mathrm{U}\right)$ Uranium Fabrication (2.0) 
LEVEL 1

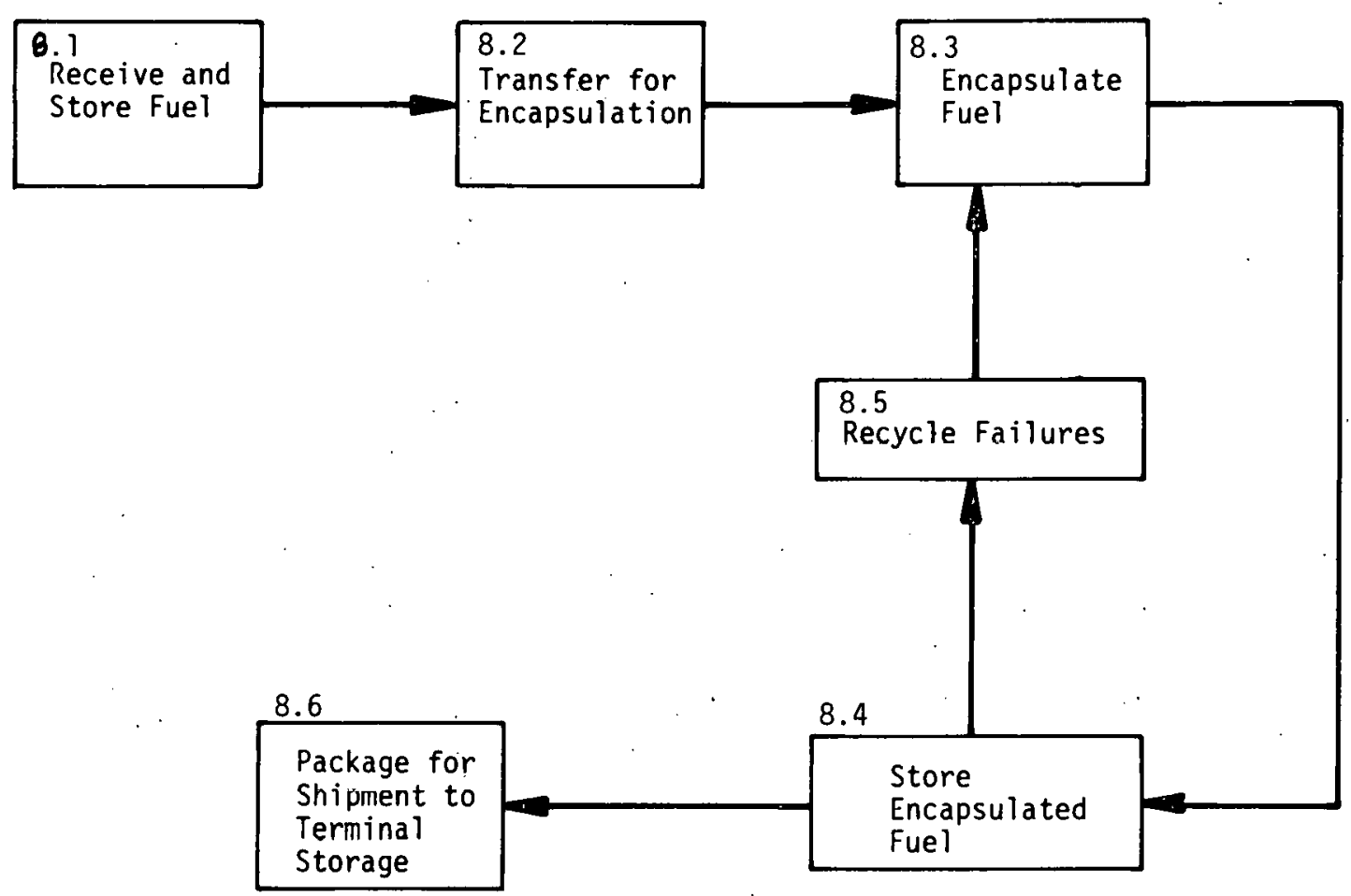

FIG. 5.19, Case 1.1.5 - Fuel Throwaway (Oxide Fue 1); Encapsulate Fuel (5.0) 
Table 5.6. Case 1.1.5 (LWR): Find Fluruwawaly (10xide liuld)

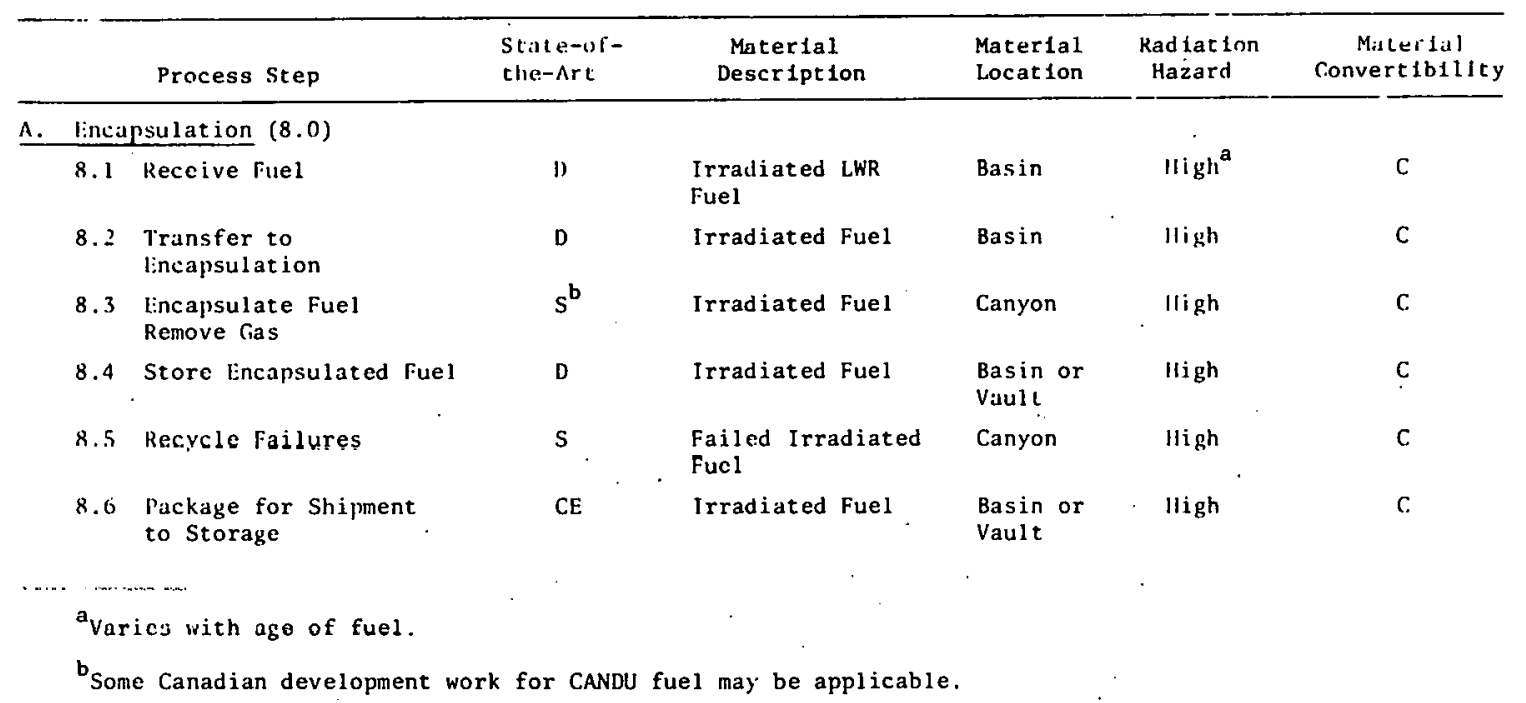

\section{Level 0}

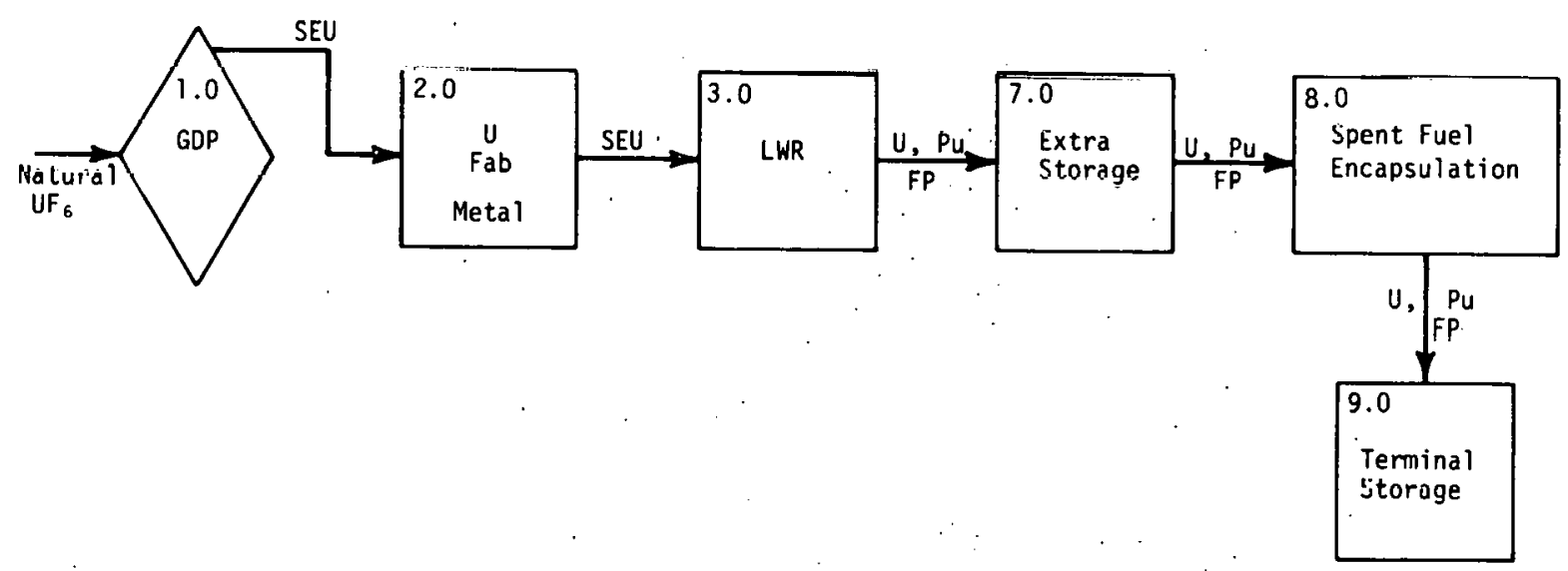

Fig. 5.20. Case 1.1.6 - Fuel Throwaway (Metal ruel) 
LEVEL 1

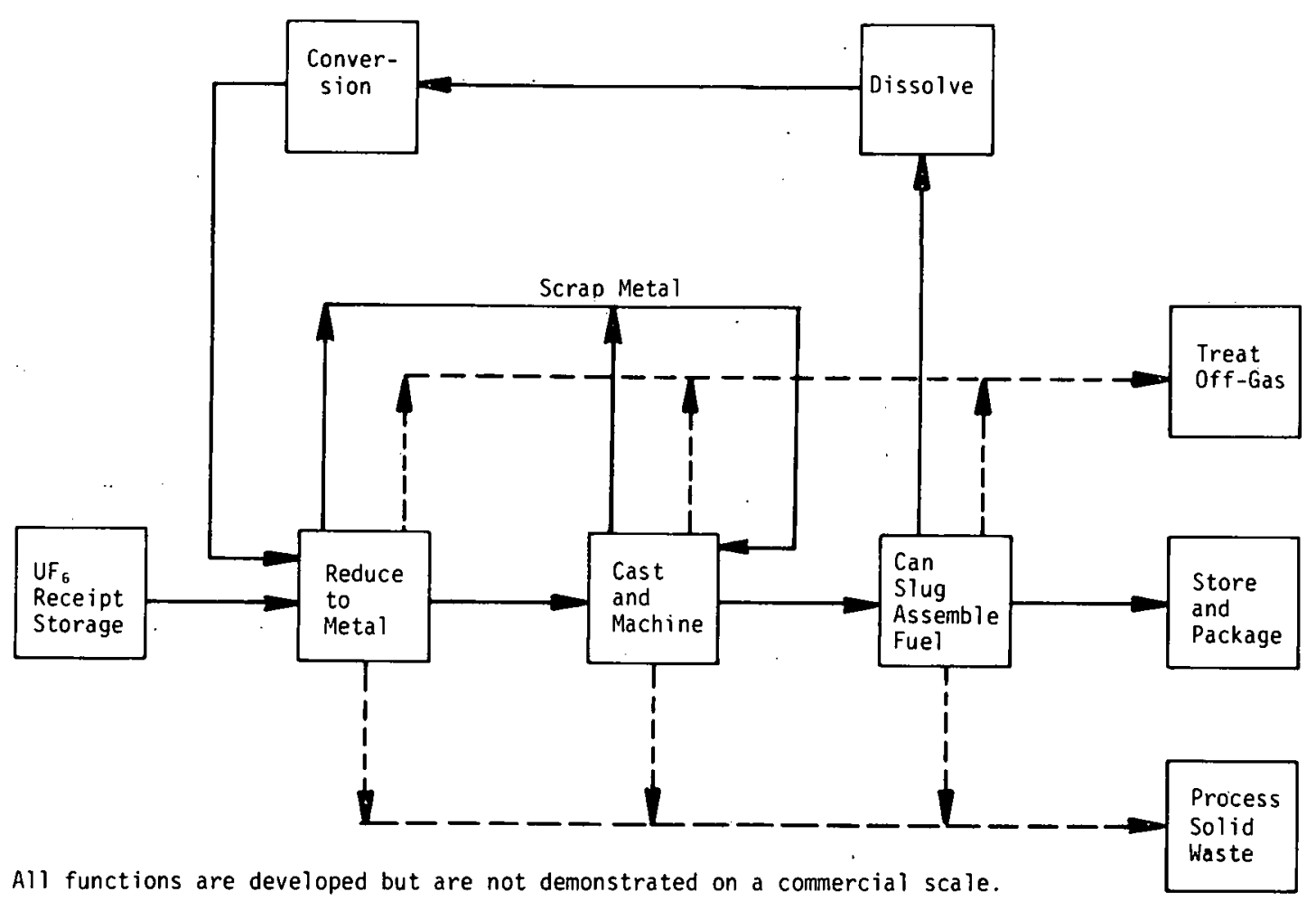

Material is a negligible radiation hazard.

Material convertibility is Category B for all steps except "Treat Off-Gas" and "Process Solid Waste."

Fig. 5.21. Case 1.1.6 - Fuel Throwaway (Metal Fuel); Slightly Enriched $\left(2-4 \%{ }^{235} \mathrm{U}\right)$ Uranium Fabrication (2.0) 
LEVEL 1

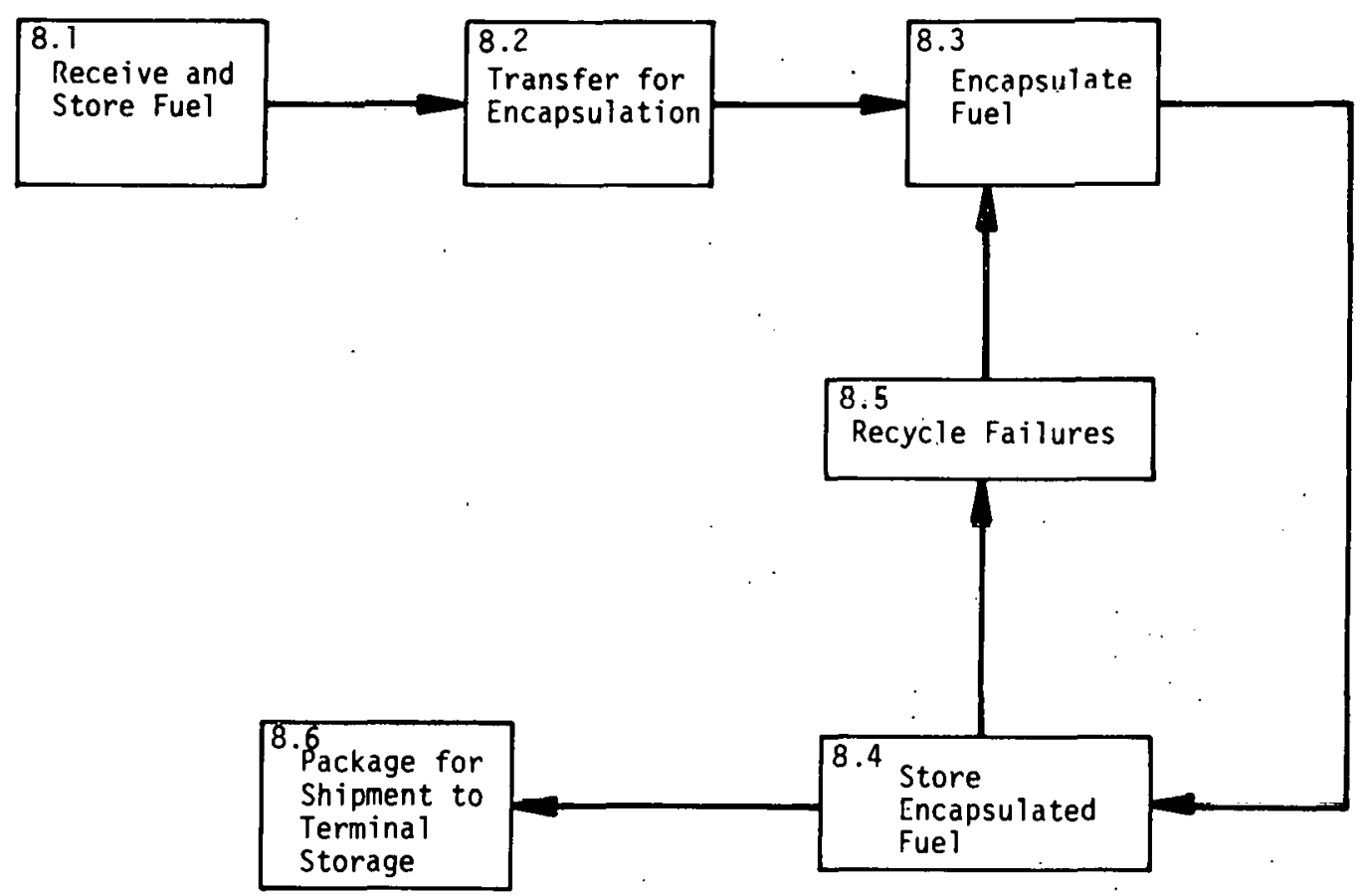

Fig. 5.22. Case 1.1.6 - Fuel Throwaway (Metal Fuel); Fnrapsulate Fuel (8.0)

Table 5.7. Comparison of Oxide and Metal Fuel Cycles for LWR

\begin{tabular}{|c|c|c|}
\hline r.ys 1 e & nxide & Me.tal \\
\hline Fuel Enrichment, $\%{ }^{235} U$ charged & 3.2 & $1 . \dot{5}$ \\
\hline Fuel Exposure, MWD/tonne & 30,000 & $12,000 \cdot(6000)^{8}$ \\
\hline $\begin{array}{l}\text { Uranium Feed Requircd, } \\
\text { Tails }=0.25 \% 2{ }^{3} 5 \mathrm{U} \text { (throwaway) } \mathrm{kg} / \mathrm{kg} \text { fuel }\end{array}$ & $5.8 \overline{7}$ & 2.71 \\
\hline Normalized and Corrected for Fuel Exposure & 1.0 & 1.15 \\
\hline $\begin{array}{l}\text { Enrichment Required, } \\
\text { Tails }=0.25 \% 235 \mathrm{U} \text { (throwaway), SWU } / \mathrm{kg} \text { fuel }\end{array}$ & 4.21 & 1.06 \\
\hline Normalized and Corrected for Fuel Exposure & 1.0 & 0.63 \\
\hline Pu Produced, kg fissile/MT & 6.2 & 4.1 \\
\hline Relative Pu Produced, kg/reactor-year & 1.0 & $\sim 1.5$ \\
\hline
\end{tabular}

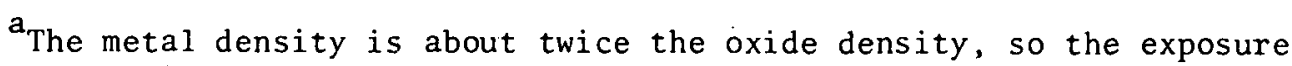
conversion is necessary for exposure comparisons. 
probably raise formidable problems with respect to safety (metal-water reaction in case of a fuel failure) and exposure (fuel growth) characteristics. Nor does the use of uranium metal fuel appear to have any safeguards or non-proliferation advantages.

Operating characteristics of uranium oxide and uranium metal fuel cycles are compared in Table 5.8. The estimates indicate some enrichment savings, but more ore consumption with metal fuel. The plutonium produced in the fuel would be about $80 \%$ fissile, and considerably more plutonium would be produced annually with metal fuel. The estimates are based on metal fuel exposures that are considered difficult to attain without major penalties on LWR power as a consequence of fuel growth. If a major metallurgical program were initiated, metal fuel for use in LWR's might be available in about 20 years (10 years for development and 10 years to commercialize and license the fuel cycle). Licensing the uranium metal fuel cycle in the U.S. may be difficult because the safety reviews would address the risk of a metal-water reaction in the event of a cladding failure. The chemical energy is high for the metal-water reaction, but negligible for uranium oxide fuel.

Chemical recovery of plutonium from metal fuel diverted from the throwaway mode is no more difficult than from oxide fuel. The waste volume occupied by the irradiated metal fuel discharged from LWR would equal or exceed that of oxide fuel because of the lower exposure attainable with metal fue1.

\subsubsection{Case 1.1.7 (LWR): Recycle of Uranium and Uranium-Plutonium Oxide (Coprocessed)}

Level 0 segments are shown schematically in Figure 5.23; Leve1 1 steps, in Figures 5.24, 5.25, and 5.26. The state-of-the-art and material characteristics for the chemical reprocessing step (4.0) and the MOX fabrication step (5.0) are shown in Table 5.9.

This case is similar to Case 1.1 .3 except a source of high radiation has not been deliberately added to the plutonium-containing stream as a non-proliferation measure. This case is analyzed to identify the benefit, if any, of radiation in the plutonium stream as a proliferation deterrent. 
Table 5.8. Case 1.1.6 (LWR): Fuel Throwaway (Metal Fuel)

\begin{tabular}{|c|c|c|c|c|c|c|c|}
\hline & & Process Step & $\begin{array}{l}\text { State-of- } \\
\text { the-Art }\end{array}$ & $\begin{array}{c}\text { Material } \\
\text { Description }\end{array}$ & $\begin{array}{l}\text { Material } \\
\text { Location }\end{array}$ & $\begin{array}{l}\text { Radiation } \\
\text { Hazard }\end{array}$ & $\begin{array}{c}\text { Material } \\
\text { Convertibility }\end{array}$ \\
\hline \multirow[t]{7}{*}{ A. } & \multicolumn{7}{|c|}{ Encapsulation $(8.0)$} \\
\hline & 8.1 & Receive Fuel & D & Irradiated LWR Fuel & Basin & $\mathrm{Hi} \mathrm{gh}^{\mathrm{a}}$ & $c^{a}$ \\
\hline & 8.2 & $\begin{array}{l}\text { Transfer to } \\
\text { Encapsulation }\end{array}$ & D & Irradiated Fuel & Basin & Iligh & c \\
\hline & 8.3 & $\begin{array}{l}\text { Encapsulate Fuel } \\
\text { Remove Gas }\end{array}$ & $\mathrm{s}^{\mathbf{b}}$ & $\therefore$ Irradiated Fuel & Canyon & - High & c: \\
\hline & 8.4 & Store Encapsitlated Fuel & D & Irradiated Fuel & $\begin{array}{l}\text { Basin or } \\
\text { Vault }\end{array}$ & High & c: \\
\hline & 8.5 & Rerycle Failures & $\dot{S}$ & Failed Irradiated Fuel & Canyon & $\| \mathrm{l} g \mathrm{gh}$ & $\mathrm{C}$ \\
\hline & 8.6 & Package for Shipment & $\mathrm{CE}$ & Irradiated Fuel & $\begin{array}{l}\text { Bas in or } \\
\text { Vault }\end{array}$ & High & $\mathrm{C}$ \\
\hline
\end{tabular}

${ }^{a}$ Varies with age of fuel.

${ }^{b}$ Some Canadian development work for CANDU fuel may be applicable. 
LEVEL 0

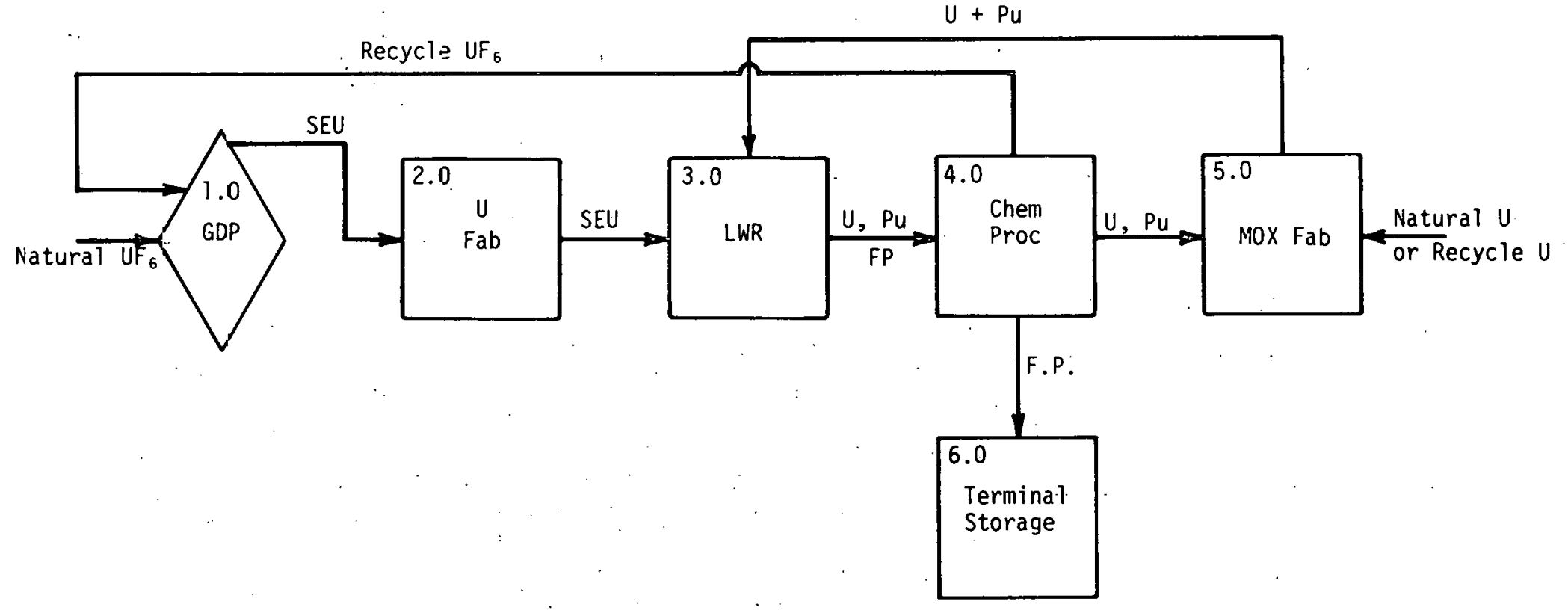

Fig. 5.23. Case 1.1.7 - Recycle of Uranium and Uranium-Plutonium Oxide (Coprocessed) 


\section{LEVEL 1}

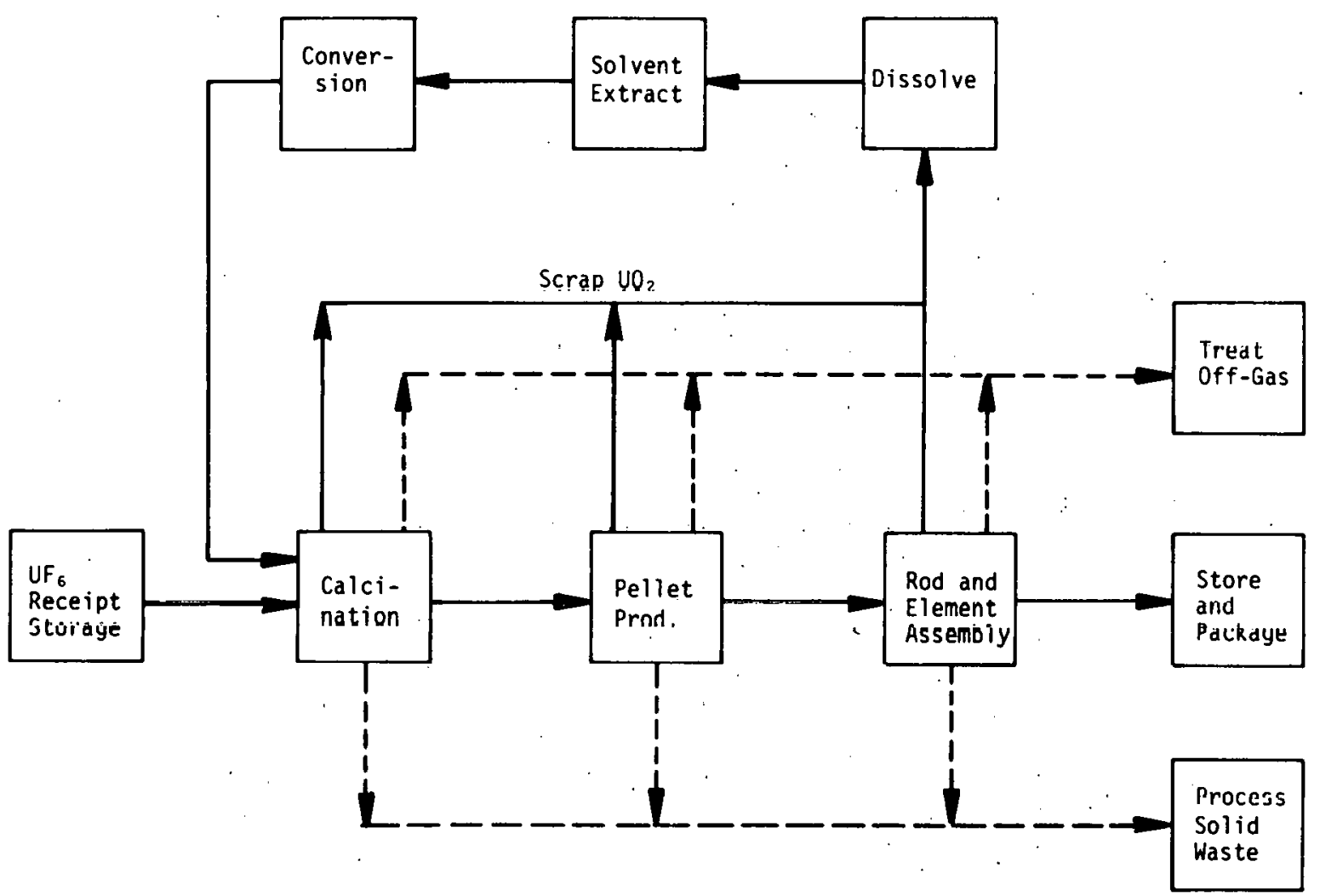

All functions are developed state of the art; material is a negligible radiation hazard.

Material convertibility is Category B for all steps except "Treat Off-Gas" and "Process Solid Waste."

Fig. 5.24. Case 1.1.7 - Recycle of Uranium and Uranium-Plutonium Oxide (Coprocessed); STightly Enriched (2-4\% $\left.{ }^{23} \mathrm{U}\right)$ Uranium rabrication ( 2.0$)$ 
LEVEL 1

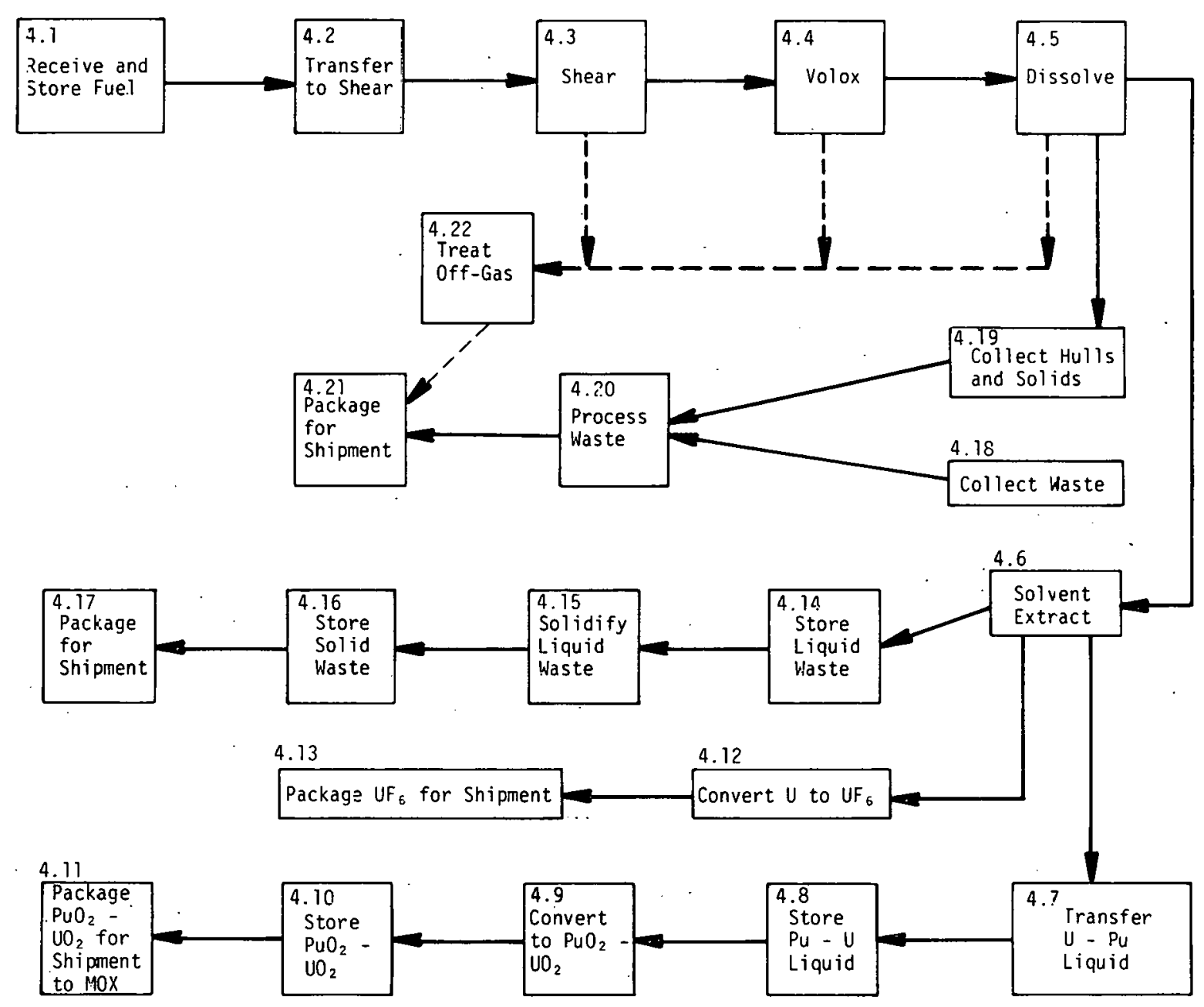

Fig. 5.25. Case 1.1.7 - Recycle of Uranium and Uramium-P.lutonium Oxide (Coprocessed); Chemical Reprocessing (4.0) 
LEVEL I

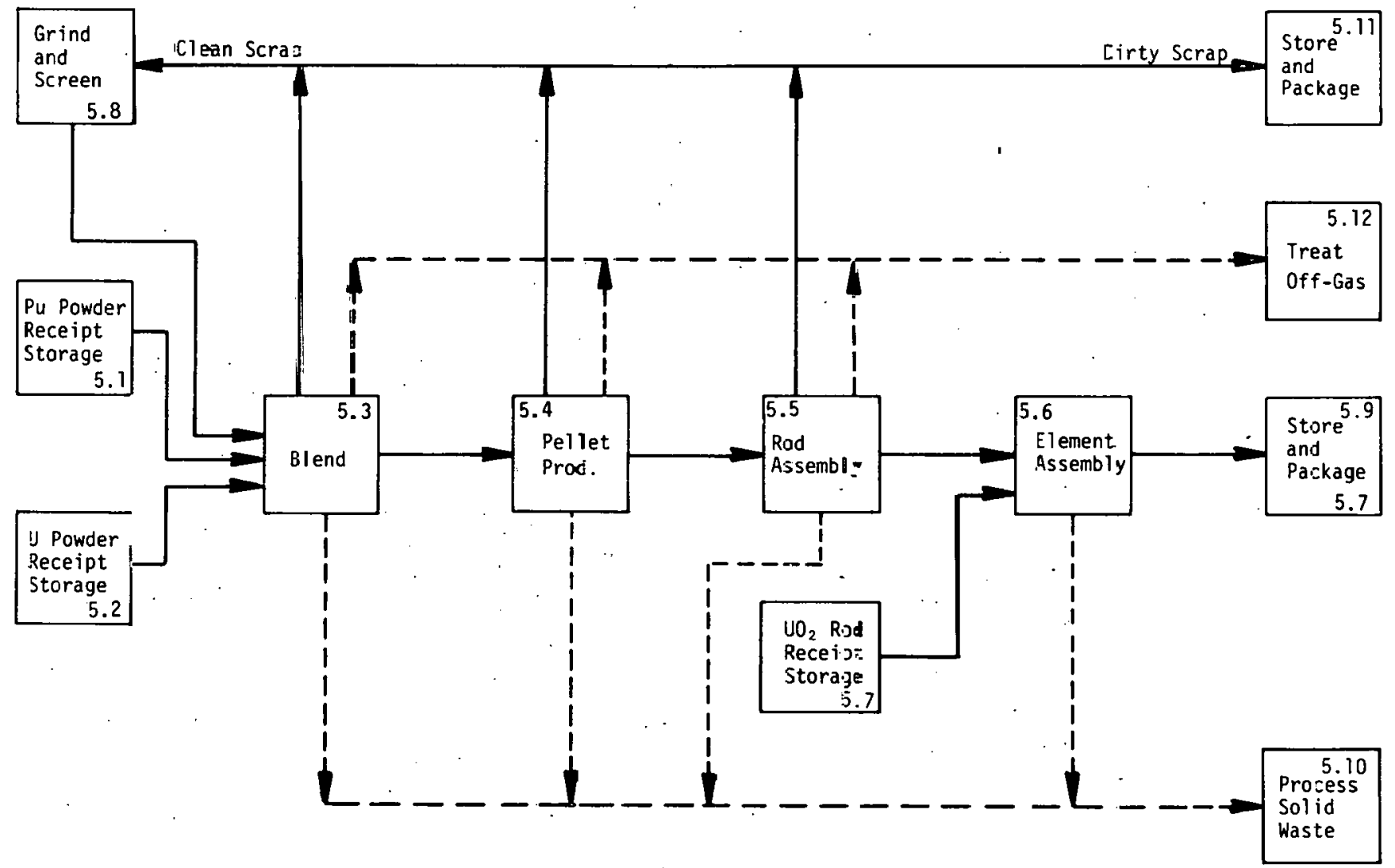

Fij. 5.26. Case 1.1.7 - Recycle of Uraniun and IJranium-Plutonium Oxide (Coprocessed); MOX Fabrization (5.0) 
Table 5.9. Case 1.1.7 (LWR): Recycle of Uranium and Uranium-Plutonium (Coprocessed)

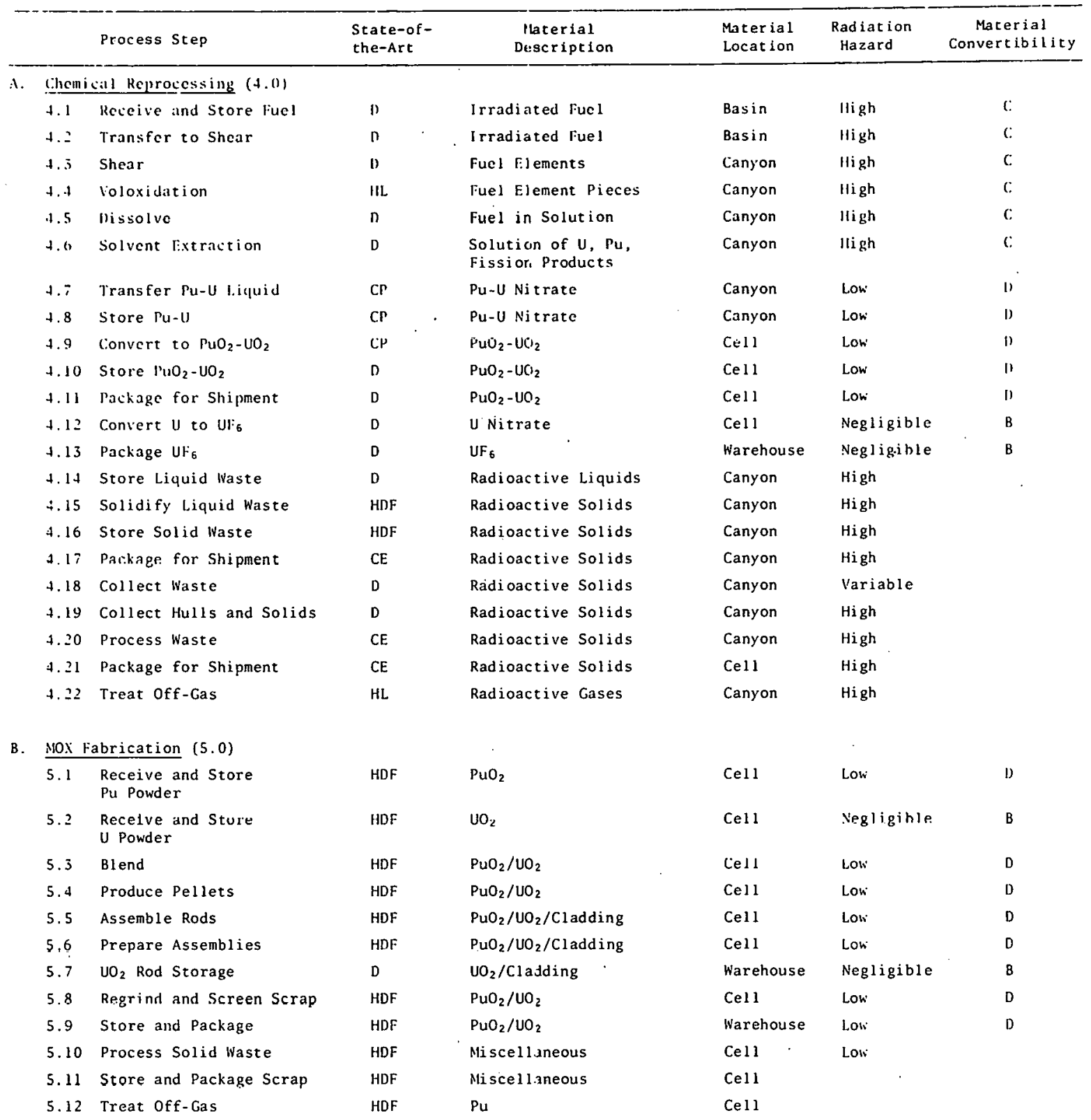


The major advantages of this coprocessing process are compatibility with U.S. qualified and licensed fuel fabrication methods, some possible small economic advantage in fuel fabrication, and a reduction in the risk of successful diversion of plutonium by subnational groups. The mass of $\mathrm{UO}_{2}-\mathrm{PuO}_{2}$ required for a given amount of plutonium is increased by about a factor of 8 over the spiked, separated plutonium (Case 1.1.2), but is less than the corresponding mass of irradiated fuel by a factor of 12. Therefore, the advantage of this fuel cycle is related to domestic safeguards or to internationally controlled reprocessing centers.

Preliminary study of the uranium-plutonium coprocessing has indicated that the Pu-U mixture obtained from solvent extraction for coprecipitation (Figure 5.25) should contain $12 \% \mathrm{Pu}$ for LWR. The mixture will be diluted to about $5 \% \mathrm{PuO}_{2}$ (Figure 5.26) at the MOX facility for fabrication into LWR fuel. Higher concentrations may be required for LMFBR fuel processing. If further study permits increasing the plutonium concentration beyond $12 \%$, some cost-savings would be expected.

\subsubsection{Case 2.1.6 (GCR): Fue1 Throwaway - Metal Fue1 (Magnox)}

Level 0 segments are shown srhematically in Figure 5.27; Level 1 steps in Figures 5.28 and 5.29. The statc-of-the-art and material characteristics for this case are shown in Table 5.10.

The processes described in this case are for a throwaway fuel cycle which is representative of the British gas-cooled reactor (Calder Hall type). This reactor concept is now considered obsolete and non-competitive by the U.S. because of the low power-density inherent with natural uranium metal fuel (Magnox-clad) cooled by carbon dioxide gas. A typical reactor power level is only $200 \mathrm{MW}_{\mathrm{th}}(35 \mathrm{MW})$. Although the case is defined as fuel throwaway, the British have reprocessed fuel from Calder Hall reacturs using the bnsic. Murex process.

\subsubsection{Case 2.1.7 (GCR) Recycle of Uranium and P1utonium in Advanced Gas Reactors (Oxide Fue1)}

Leve1 0 segments are shown schematically in Figure 5.30; Level 1 steps, in Figures 5.31, 5.32, and 5.33. The state-of-the-art and material attractiveness for the chemical processing step (4.0) and the MOX fabrication step (5.0) are shown in Table 5.11. 
LEVEL 0

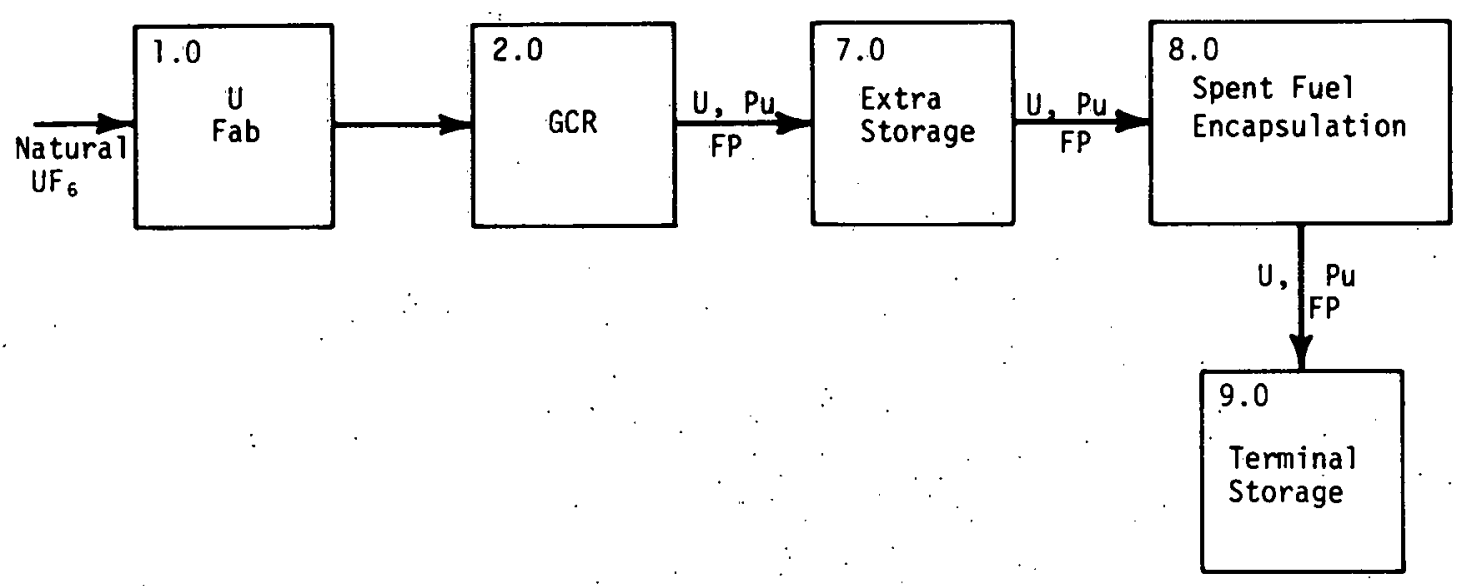

Fig. 5.27 Case 2.1.6 - Fuel Throwaway-Metal Fuel (Magnox) 
LEVEL 1

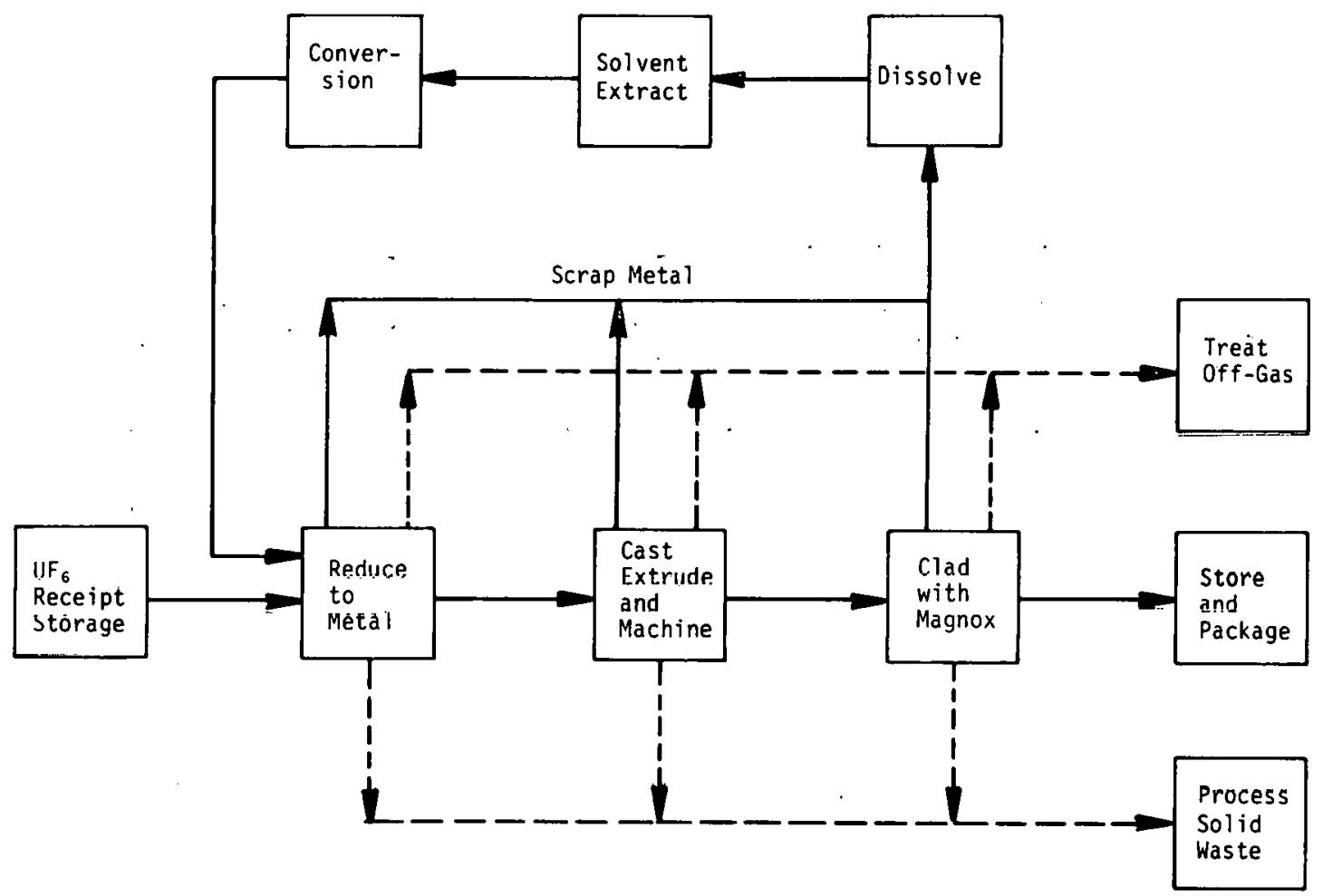

All functions are developed state of the art, but are not demonstrated on a commercial scale. Radiation hazard is negligible.

Material convertibility iș Category B for all steps except "Treat Off-Gas" and "Process Solid Vlaste."

Fig. 5.28. Case 2.1.6 - Fuel Throwaway-Metal Fuel (Magnox); Natural Uranium Metal Fabrication (1.0) 
LEVEL 1

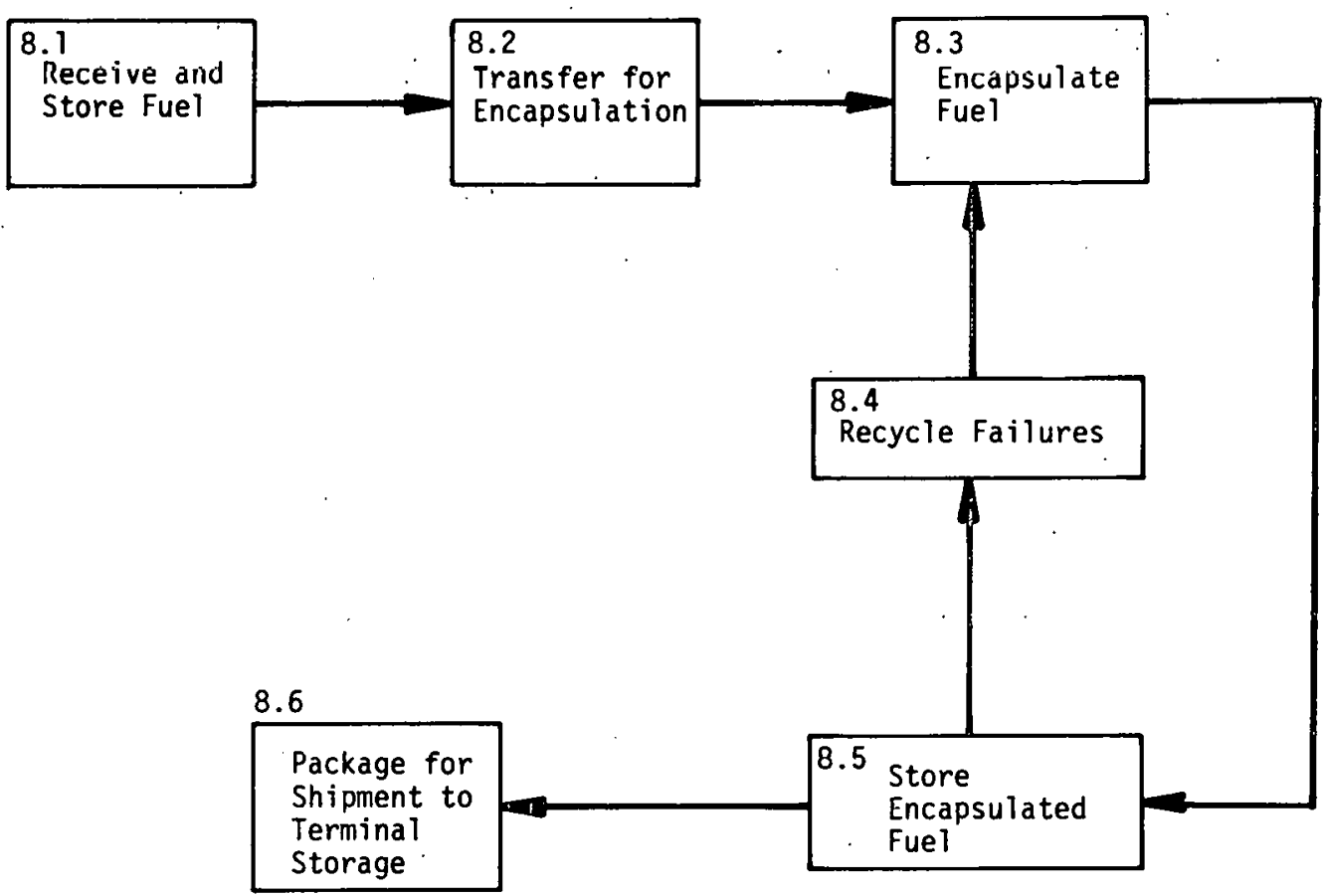

Fig. 5.29. Case 2.1.6 - Fuel Throwaway-Meta 1

Fuel (Magnox); Encapsulated Fuel (8.0) 
Table 5.10. Case 2.1.6 (GCK): Fue1 Throwaway (Magnox)

\begin{tabular}{|c|c|c|c|c|c|c|c|}
\hline \multicolumn{3}{|r|}{ Process Step } & \multirow[t]{2}{*}{$\begin{array}{l}\text { State-of- } \\
\text { the-Art }\end{array}$} & $\begin{array}{l}\text { Macerial } \\
\text { Description }\end{array}$ & \multirow[t]{2}{*}{$\begin{array}{l}\text { Macerial } \\
\text { Location }\end{array}$} & \multirow[t]{2}{*}{$\begin{array}{l}\text { Radlation } \\
\text { Hazard }\end{array}$} & \multirow[t]{2}{*}{$\begin{array}{c}\text { Material } \\
\text { Convertibility }\end{array}$} \\
\hline A. & \multicolumn{3}{|c|}{ Encapsulation (8.0) } & & & & \\
\hline & 8.1 & Receive Fuel & D & Irradiated Magnox Fuel & Basin & $\mathrm{High}^{\mathrm{a}}$ & $c^{a}$ \\
\hline & 8.? & Transfer to Encapsulation & D & Irradiated Fuel & Basin & $\mathrm{High}$ & C \\
\hline & 8.3 & $\begin{array}{l}\text { Encapsulate Fuel } \\
\text { Remove Gas }\end{array}$ & $s^{b}$ & Irradiated Fuel & Canyon & $\mathrm{High}$ & C \\
\hline & 8.4 & Store Encapsulated Fuel & D & Irradiated Fuel & $\begin{array}{l}\text { Basin or } \\
\text { Vault }\end{array}$ & High & $\mathrm{C}$ \\
\hline & 8.5 & Recycle Failures & $\mathrm{S}$ & Failed Irradiated Fuel & Canyon & $\mathrm{High}$ & $c$ \\
\hline & 8.6 & $\begin{array}{l}\text { Package for Shipment to } \\
\text { Storage }\end{array}$ & $\mathrm{CE}$ & Irradiated Fuel & $\begin{array}{l}\text { Basin or } \\
\text { Vault }\end{array}$ & $\mathrm{High}$ & C \\
\hline
\end{tabular}

a Varies with age of fuel.

${ }^{\text {b }}$ Some Canadian development work for CANDU fuel may be applicable. 
LEVEL 0

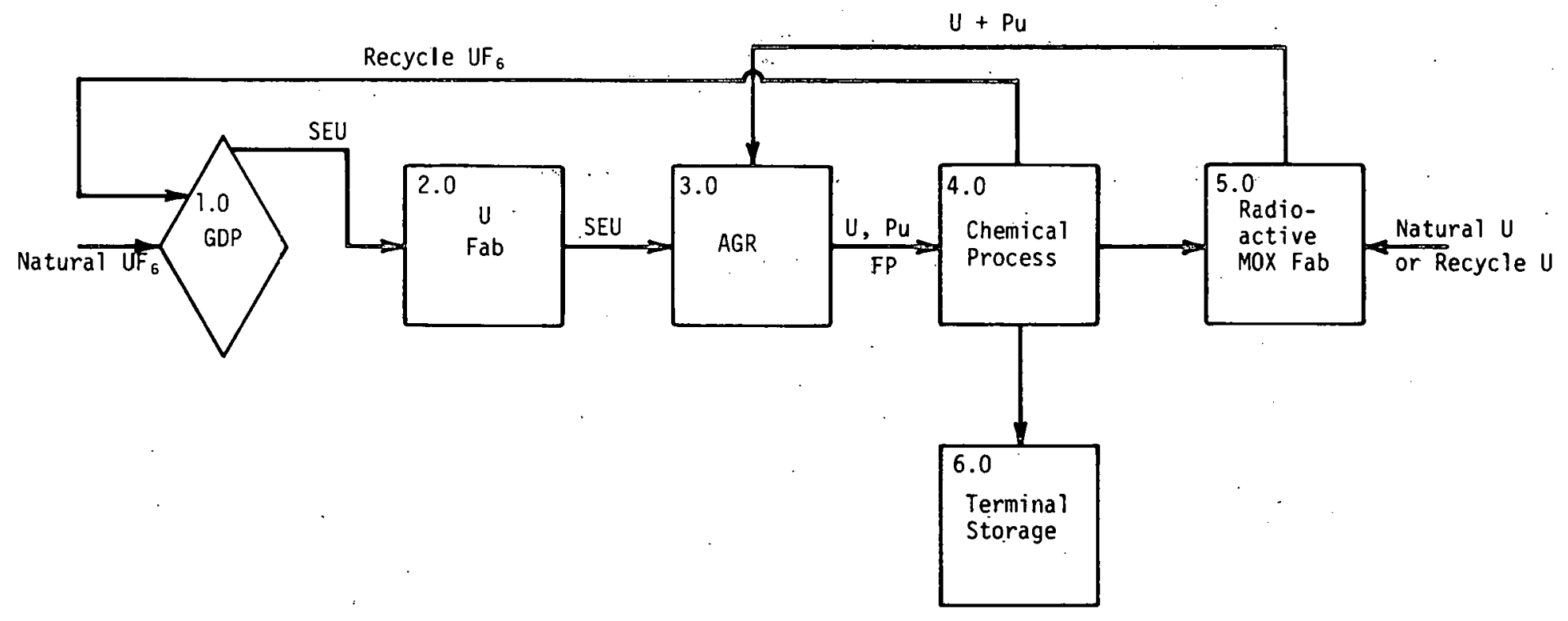

Fig. 5.30. Case 2.1.7 - Recycle of Uranium and Plutonium in AGR (Oxide Fuel) 
LEVEL 1

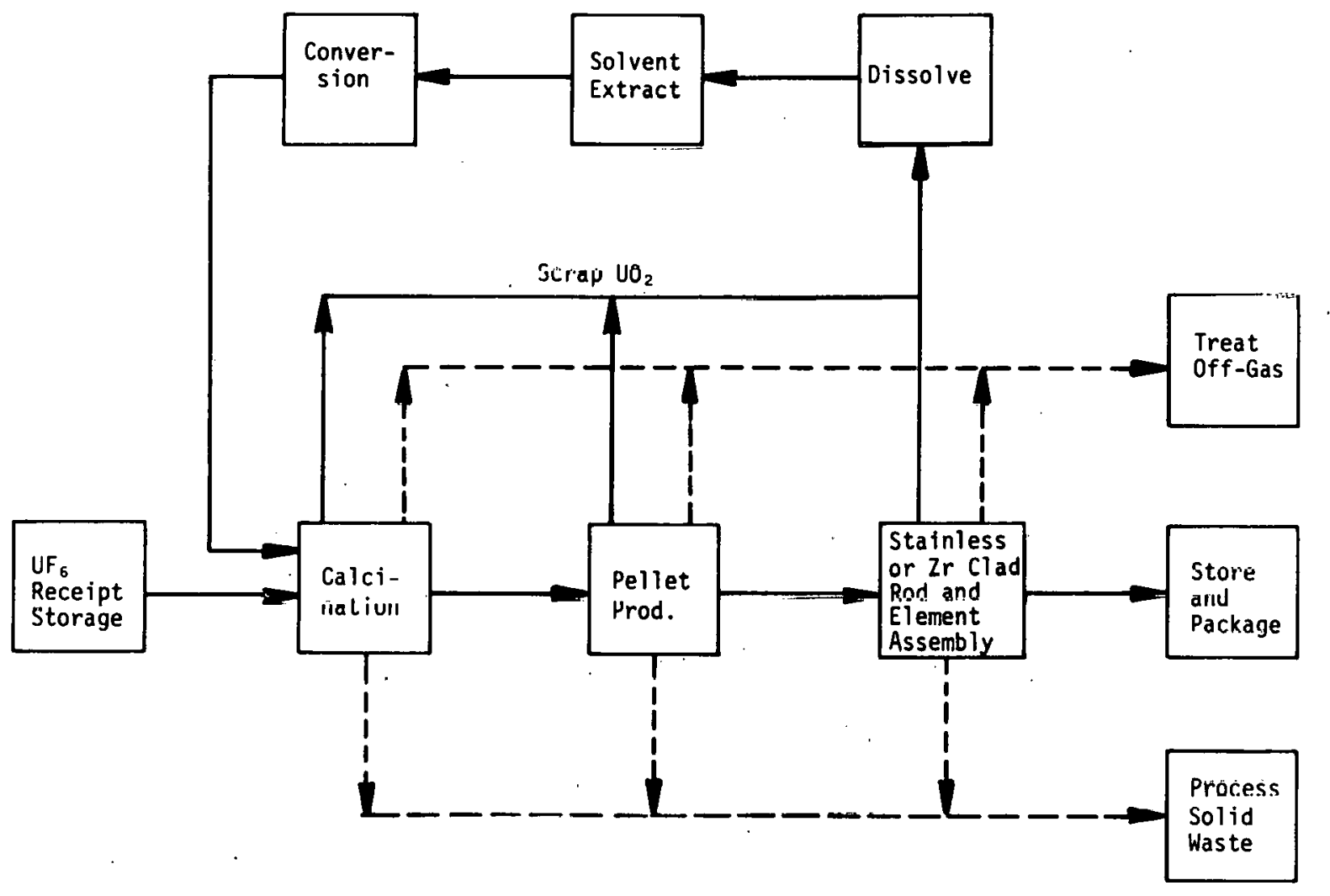

AIl functions are developed state of the art; radiation hazard is negligible.

Material convertibility is Category $B$ for all steps except

"Treat Off-Gas" and "Process Solid Waste."

Fig. 5.31. Case 2.1.7 - Recycle of Uranium and Plutonium in AGR (Oxide Fuel); Slightly Enriched (2-4\% $\left.23{ }^{5} \mathrm{U}\right)$

Uranium Fabrication (2.0) 
LEVEL 1

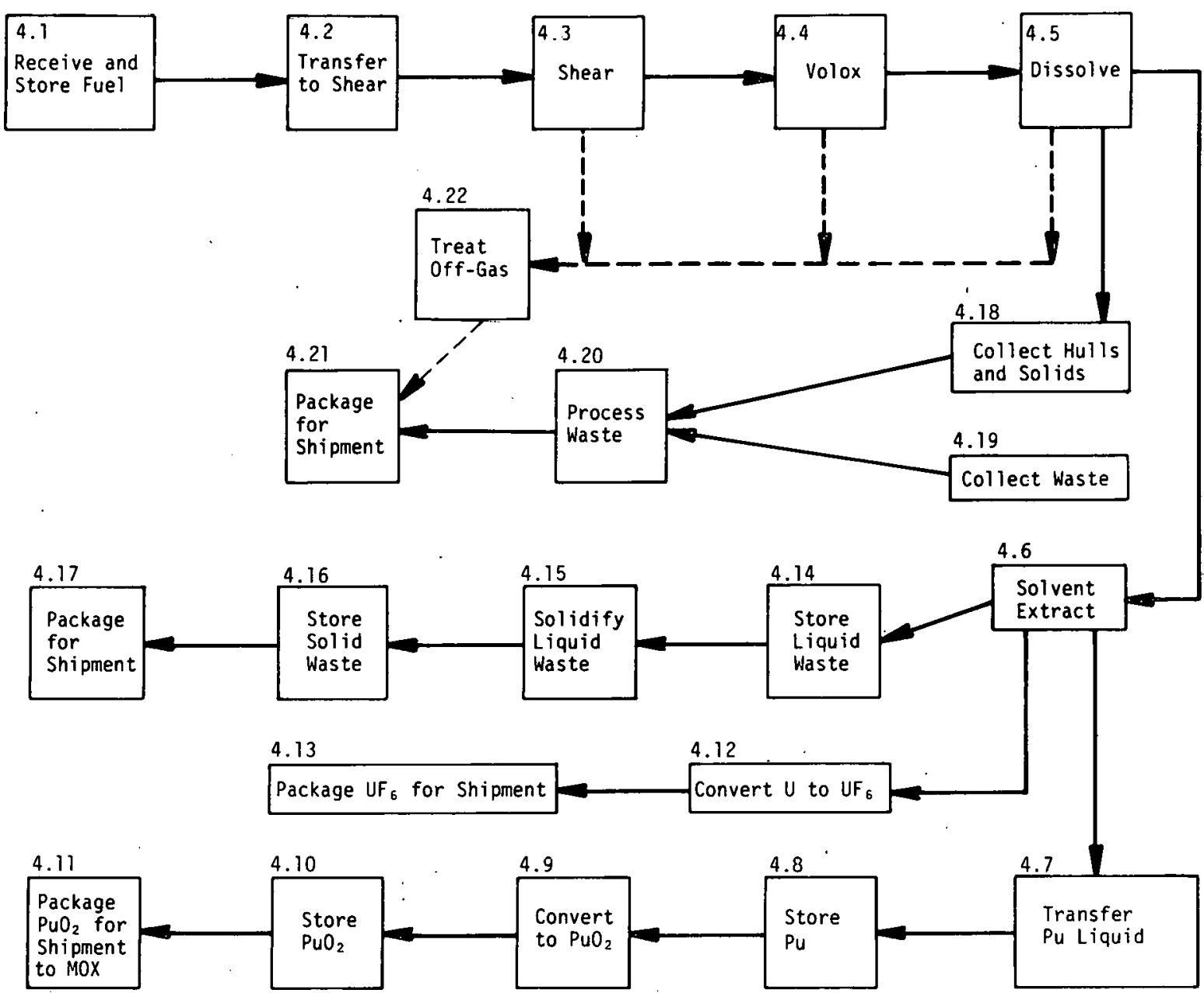

Fig. 5.32. Case 2.7.7 - Recycle of Uranium and Plutonium in AGR (Oxide Fuel); Chemical Reprocessing (4.0) 
LEVEL I

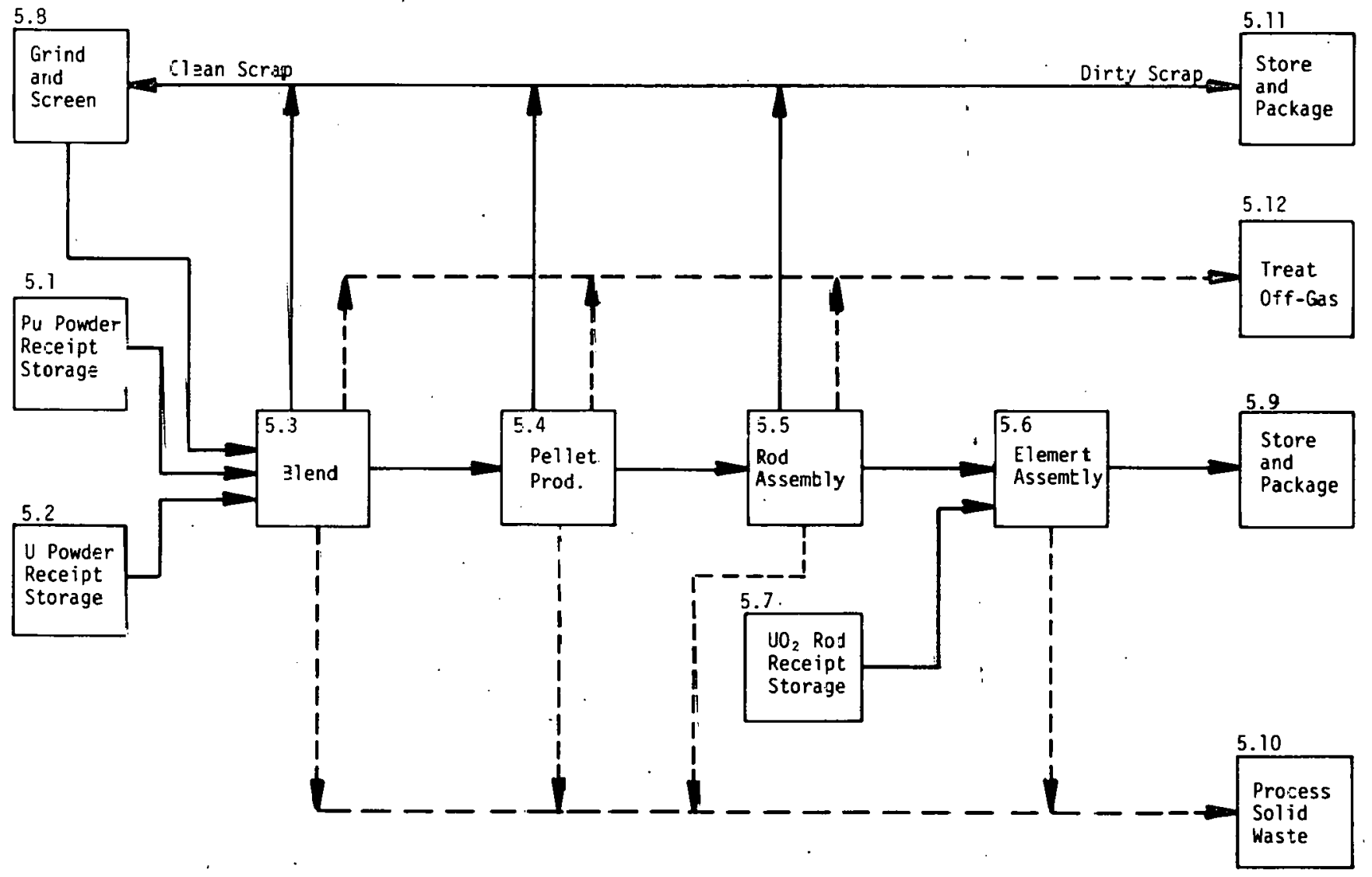

Fig. 5.33. Case 2.1.7 - Recycle of Uranium and Plutonium in AGR (0xide Fuel); MJX Fatrication (5.0) 
Table 5.11. Case 2.1.7 (GCR): Recycle of Uranium and Plutonium in AGR (Oxide Fuel)

\begin{tabular}{|c|c|c|c|c|c|c|c|}
\hline & & Process Step & $\begin{array}{l}\text { State-of- } \\
\text { the-Art }\end{array}$ & $\begin{array}{l}\text { Material } \\
\text { Description }\end{array}$ & $\begin{array}{l}\text { Material } \\
\text { Location }\end{array}$ & $\begin{array}{l}\text { Radiation } \\
\text { Hazard }\end{array}$ & $\begin{array}{c}\text { Material } \\
\text { Convertibility }\end{array}$ \\
\hline \multirow[t]{23}{*}{ A. } & Chemi & cal Reprocessing (4.0) & & & & & \\
\hline & 4.1 & Receive and Store Fuel & D & I rradiated Fuel & Basin & High & c \\
\hline & 4.2 & Transfer to Shear & D & Irradiated Fuel & Basin & High & c \\
\hline & 4.3 & Shear & D & Fuel Elements & Canyon & High & c \\
\hline & 4.4 & Voloxidation & HL. & Fuel Element Pieces & Canyon & High & c \\
\hline & 4.5 & Dissolve & v & Fuel in Solution & Canyon & $\mathrm{High}$ & c \\
\hline & 4.6 & Solvent Extraction & D & $\begin{array}{l}\text { Solution of } U, P u \text {, } \\
\text { Fission Products }\end{array}$ & Canyon & High & c \\
\hline & 4.7 & Transfer Pu Liquid & D & Pu Nitrate & Canyon & Low & D \\
\hline & 4.8 & Store $\mathrm{Pu}$ & D & Pu Nitrate & Canyon & Low & D \\
\hline & 4.9 & Convert to $\mathrm{PuO}_{2}$ & HE & $\mathrm{PuO}_{2}$ & Cell & Low & D \\
\hline & 4.10 & Store $\mathrm{PuO}_{2}$ & D & $\mathrm{PuO}_{2}$ & Ce11 & Low & D \\
\hline & 4.11 & Package for Shipment & $\mathrm{D}$ & $\mathrm{PuO}_{2}$ & Cell & Low & D \\
\hline & 4.12 & Convert $\mathrm{U}$ to $\mathrm{UF}_{6}$ & D & U Nitrate & Cell & Negligible & B \\
\hline & 4.13 & Package $U F_{6}$ & D & $U F_{6}$ & Warehouse & Negligible & B \\
\hline & 4.14 & Store Liquid Waste & $\mathrm{D}$ & Radioactive Liquids & Canyon & High & \\
\hline & 4.15 & Solidify Liquid Waste & HDF & Radioactive Solids & Canyon & High & \\
\hline & 4.16 & Store Solid Waste & HDF & Radioactive Solids & Canyon & $\mathrm{High}$ & \\
\hline & 4.17 & Package for Shipment & CE & Radioactive Solids & Canyon & High & \\
\hline & 4.18 & Collect Waste & D & Radioactive Solids & Canyon & Variable & \\
\hline & 4.19 & Collect Hulls and Solids & $\mathrm{D}$ & Radioactive Solids & Canyon & High & . \\
\hline & 4.20 & Process Waste & CE & Radioactive Solids & Canyon & High & \\
\hline & 4.21 & Package for Shipment & $\mathrm{CE}$ & Radioactive Solids & Cell & High & \\
\hline & 4.22 & Treat off-Gas & HL & Radioactive Gases & Canyon & High & \\
\hline \multirow[t]{13}{*}{8.} & \multicolumn{4}{|c|}{ MOX Fabrication (5.0) } & & & \\
\hline & 5.1 & $\begin{array}{l}\text { Receive and Store } \\
\text { Pu Powder }\end{array}$ & HDF & $\mathrm{PuO}_{2}$ & Cell & Low & D \\
\hline & 5.2 & $\begin{array}{l}\text { Receive and Store } \\
\text { U Powder }\end{array}$ & HDF & $\mathrm{UO}_{2}$ & Cell & Negligible & B \\
\hline & 5.3 & B1end & $\mathrm{MDF}$ & $\mathrm{PuO}_{2} / \mathrm{UO}_{2}$ & Cell & Luk & D \\
\hline & 5.4 & Produce Pellets & HDF & $\mathrm{PuO}_{2} / \mathrm{UO}_{2}$ & Cell & Low & D \\
\hline & 5.5 & Assemble Rods & HDF & $\mathrm{PuO}_{2} / \mathrm{UO}_{2} / \mathrm{Cl}$ adding & Cell & Low & 0 \\
\hline & 5.6 & Prepare assembiles & HDF & $\mathrm{PuO}_{3} / \mathrm{HO}_{2} / \mathrm{Cl}$ adding & Cell & Lor: & D \\
\hline & 5.7 & $\mathrm{UO}_{2}$ Rod Storage & 0 & $\mathrm{UO}_{2} / \mathrm{Cl}$ adding & Warehouse & Negligible & B \\
\hline & 5.8 & Regrind and Screen Scrap & HDF & $\mathrm{PuO}_{2} / \mathrm{UO}_{2}$ & Cell & Low & \\
\hline & 5.9 & Store and Package & HDF & $\mathrm{PuO}_{2} / \mathrm{UO}_{2}$ & Warehouse & Low & \\
\hline & 5.10 & Process Solid Waste & HDF & Mi scell aneous & Cell & Low & \\
\hline & 5.11 & Store and Package Scrap & IIDF & Miscellaneous & Cell & & \\
\hline & 5.12 & Treat off-Gas & HDF & $\mathrm{Pu}$ & Cell & & \\
\hline
\end{tabular}


The processes described in this case include recycle of uranium and plutonium discharged from an advanced gas-cooled reactor (AGR). A typical example of an AGR, the Hinkley B Station, is rated at $1500 \mathrm{MW}_{\mathrm{th}}$ $\left(621 \mathrm{MW}_{\mathrm{e}}\right)$. The fuel is slightly-enriched uranium oxide pellets ( $2 \%{ }^{235} \mathrm{U}$ ) clad in stainless steel; typical fuel exposure is 18,000 MWD/Tonne. Fuel coolant is carbon dioxide gas and the reactor core structure is graphite. The fuel cycle is similar to the LWR cycle except for the lower enrichment and enhanced plutonium conversion ratio with graphite (less ore consumed) with some savings offset by the luwer fuel cxposure. Reprocessing systems are very similar to the base recycle case for LWR. Even with the similarities in fuel cycle, introduction nf a gas-cooled redicur Into the U.S. power system would probably require many years for commercialization and licensing.

\subsubsection{Case 3.1.1 (HWR): Recycle of Plutonium}

Lcve1 0 segments are shown schematically in Figure 5.34; Leve1 1 steps in Figures 5.35, 5.36, and 5.37. The 3tate-of-the-art and material attractiveness of the chemical reprocessing step (4.0) and the MOX fabrication step (5.0) are shom in Tablo 5.12 .

The CANDU reactor was developed in Canada for domestic use and for export. Current power rating of CANDU reactors is about $2200 \mathrm{MW}_{\mathrm{th}}\left(630 \mathrm{MW}_{\mathrm{e}}\right)$ and some advanced designs are projected to operate at $750 \mathrm{MW}$. The reactor can be fueled with natural uranium, but some economic benefit is calculated with slight enrichment $\left(\sim_{1} \%{ }^{235} U\right)$ or with plutonium recycle. Higher capital costs are estimated for HWRs than for LWRs because nf the cost of heavy water and engineering refinements to minimize heavy water leakage. The 1ncentives and impediments for introduction of HWRs in the U.S. have been studied. Commercialization and licensing of the HWR design in the U.S. would probably require many years.

Under current economic conditions in the U.S., reprocessing and recycle of plutonium from liWRs is probably not attractive. Other countries lacking uranium ore and enrichment facilities (e.g., Brazil) plan on plutonium recovery. The processes for plutonium recovery are very similar to those of the base case for recycle of LWR fuel. 
LEVEL 0

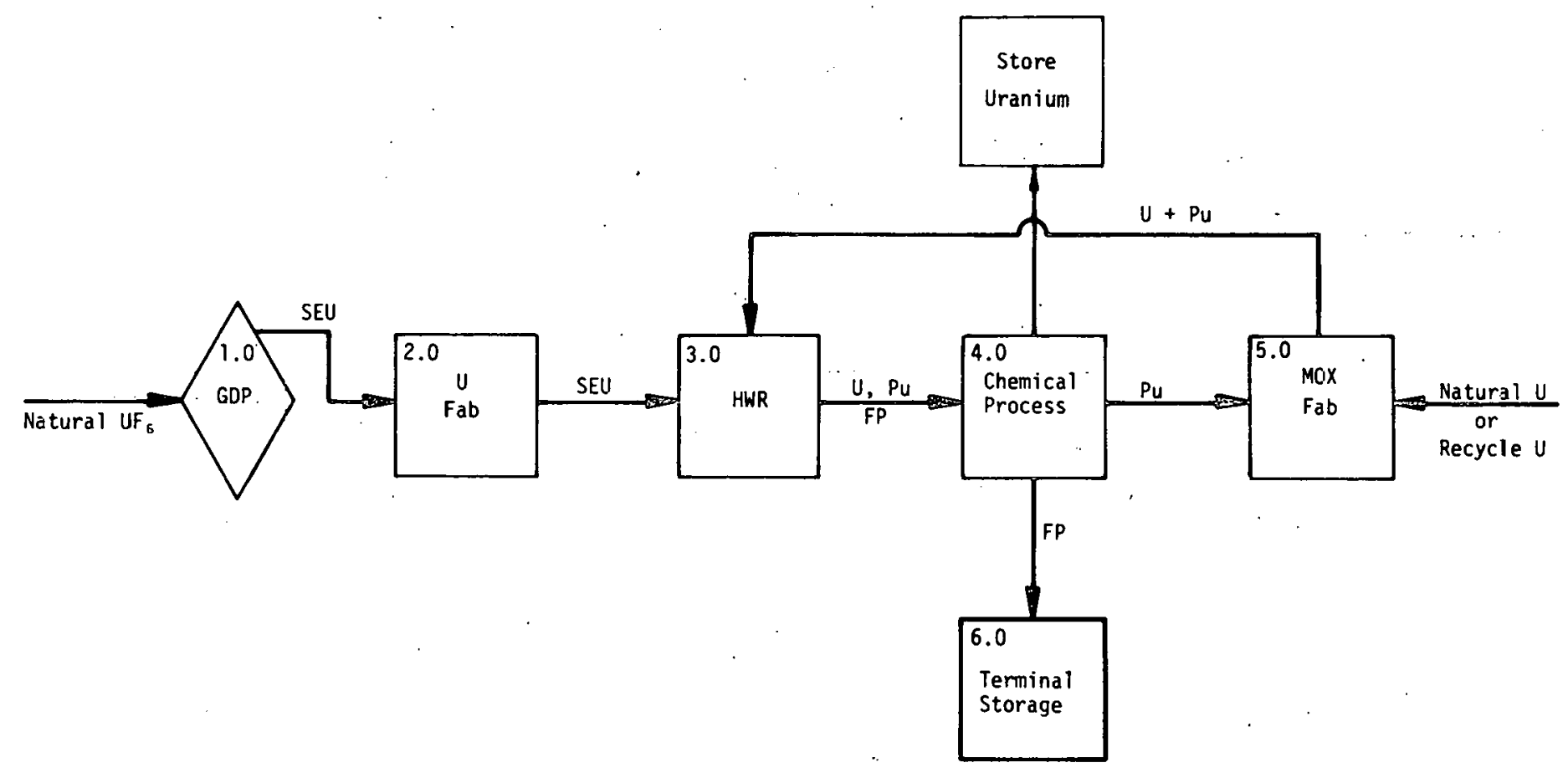

Fig. 5.34. Case 3.1.1 - Recycle of Plutonium 
LEVEL 1

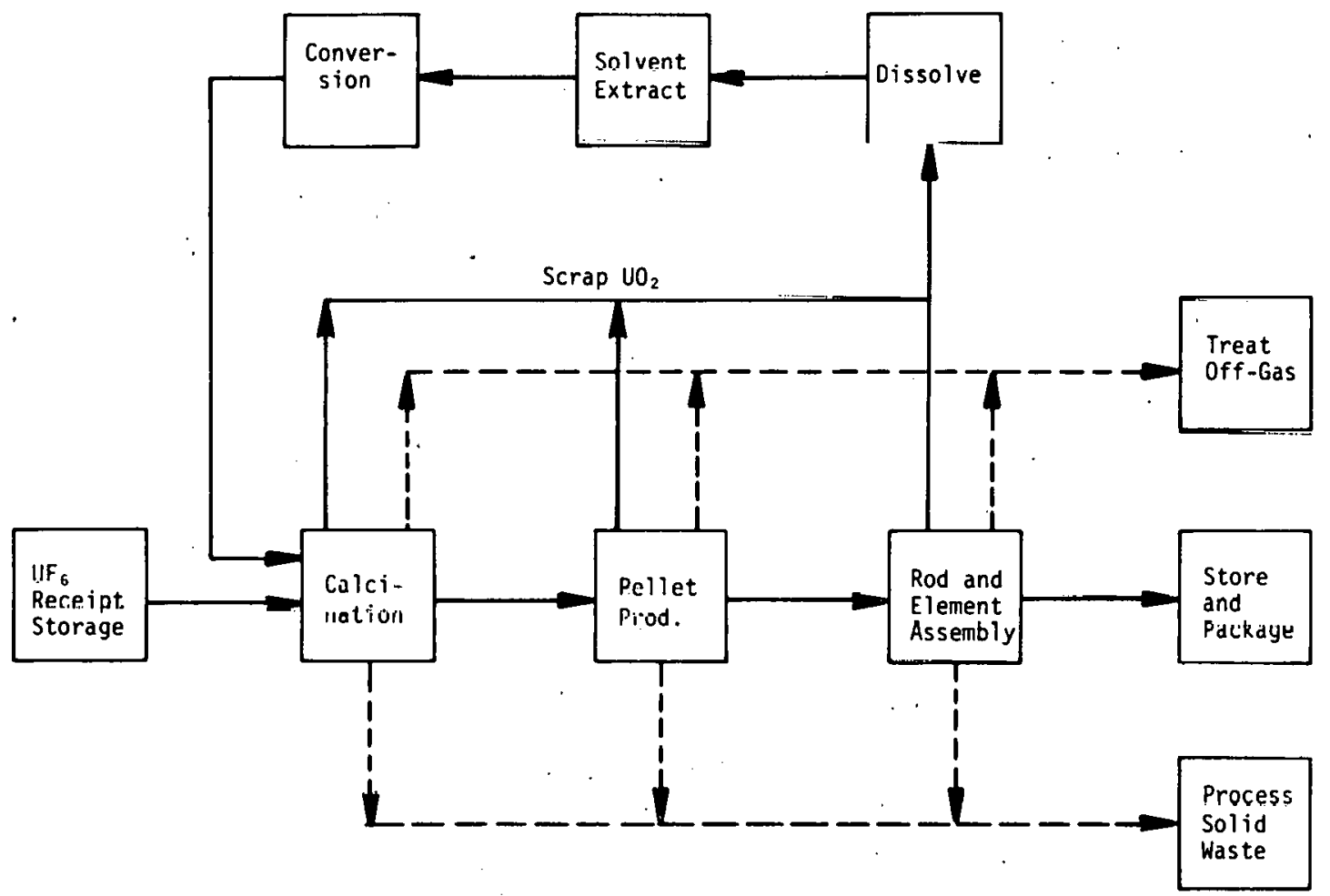

All functions are developed state of the art in Canada; radiation level is negligible.

Material convertibility is Category B for all steps except "Treat Off-Gas" and "Process Solid Waste."

Fig. 5.35. Case 3.1.1 - Recycle of Plutontum; S1ightly Enriched $(0.7-1.5 \% 235 \mathrm{U})$ Uranium Fabrication (2.0) 
LEVEL 1

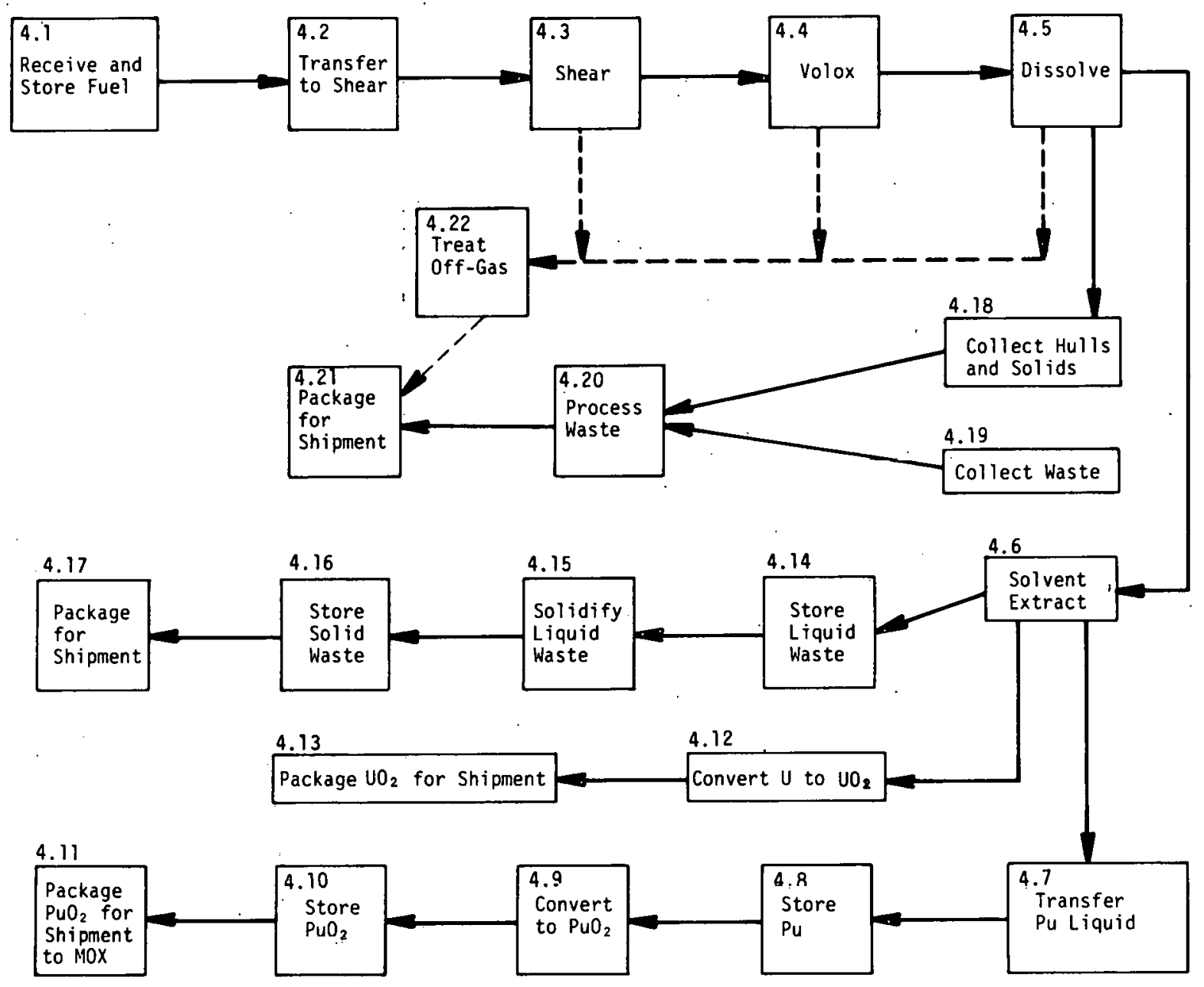

Fig. 5.36. Case 3.1.1-Recycle of Plutonium; Chemical Reprocessing (4.0) 
LEVEL 1

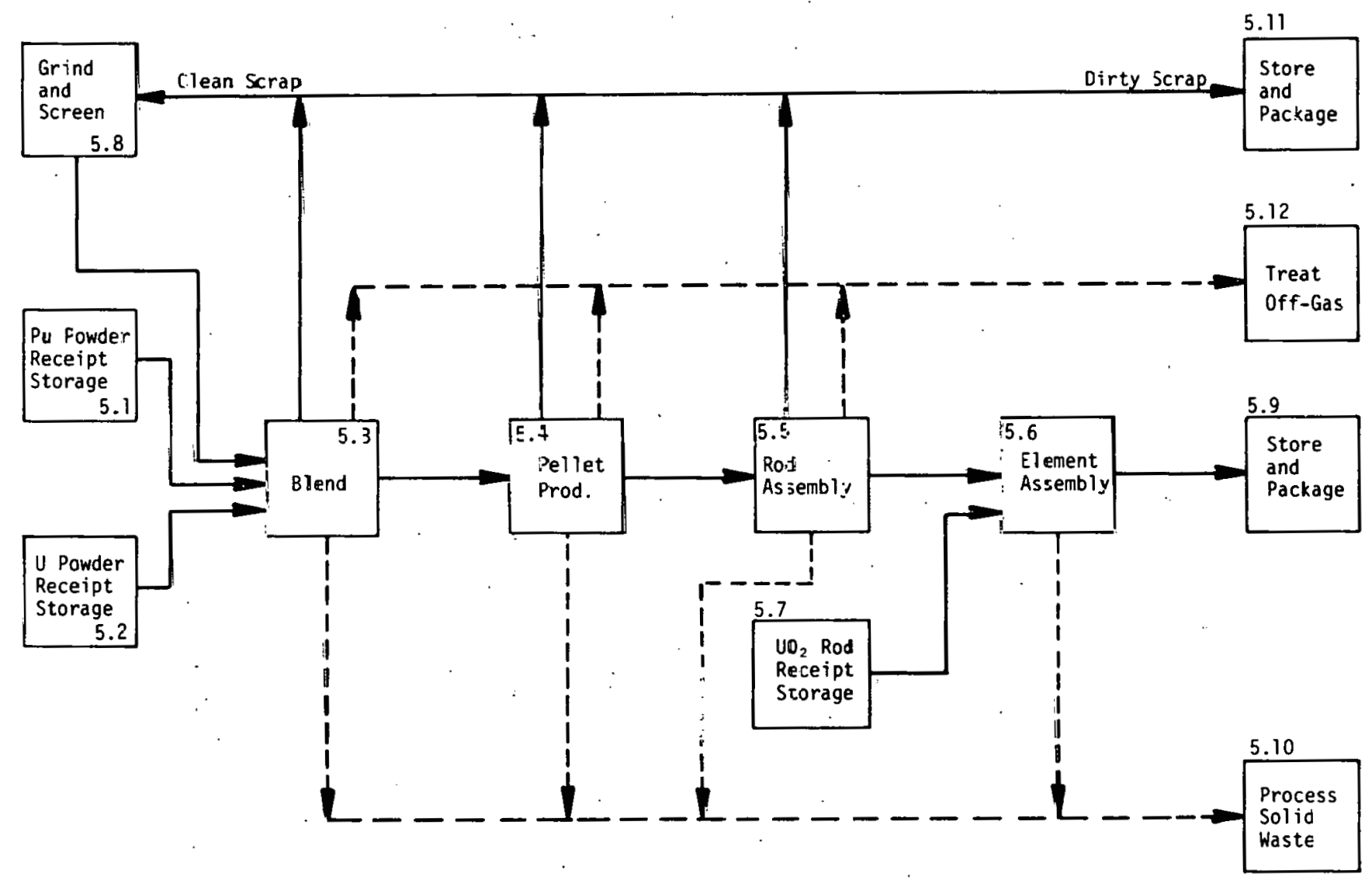

Fig. 5.37. Case 3.1.1 - Recycle of Plutoni:dm; MOX Fabrication (5.0) 
Table 5.12. Case 3.1.1 (HWR): Recycle of Plutonium

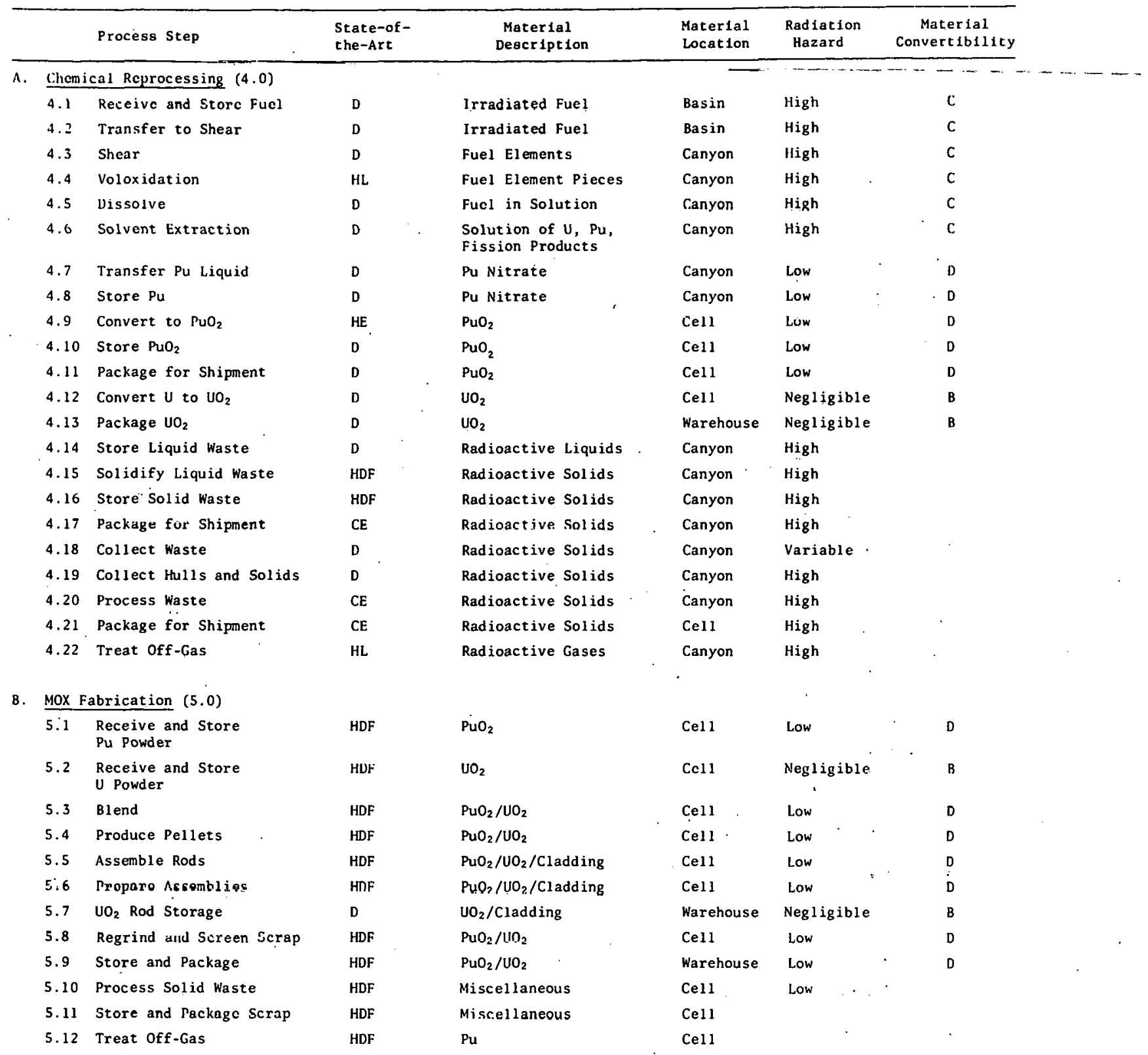


The uranium recovered from HWR fuel is about $0.3 \%{ }^{235} \mathrm{U}$ (somewhat higher with enriched fuel loading) and, hence, not economical for recycle. Storage of uranium for eventual use in breeder reactors is assumed.

\subsubsection{Case 3.1.2 (HWR): Recycle of Spiked Plutonium}

Leve1 0 segments are shown schematically in Figure 5.38; Level 1 steps, in Figures 5.39, 5.40, and 5.41. The state-of-the-art and material attractiveness for the chemical processing step (4.0) and the MOX fabrication step (5.0) are shown in Table 5.13 .

Difficulties in providing an effective spiking method for plutonium fuel are discussed separately under Section 5.4 , "Spiking Plutonium."

\subsubsection{Case 3.1.3 (HWR): Fuel Throwaway - Oxide Fue1}

Level 0 segments are shown in Figure 5.42 ; Level 1 steps, in Figures 5.43 and 5.44. The state-of-the-art and material attractiveness are shown in Table 5.14 .

The CANDU reactors are currently operated in the fuel throwaway mode. Annual fuel throughput for HWRs is two or three times that of LWRs because the fuel exposure is only about 7,000 MWD/ton metal compared to about 30,000 MWD/ton for LWRs. This comparison is basod on the same thermal output from both types of reactors. The conversion ratio of plutonium is higher in HWRs than for LWRs; thus, the stored HWR fuel would become a future resource should a decision be made to phase in breeder reactors as a consequence of high uranium cost or short supply.

\subsubsection{Case 3.3.1 (HWR): Tandem Fue1 - Reconstituted LWR Fue1}

Leve1 0 segments are shown in Figure 5.45 ; Level 1 steps, in Figures $5.46,5.47$, and 5.48. I'he state-of-the-art and material characteristics fur Operation 5.0 (Reconstitute Fuel for HWR) and Operation 8.0 (Spent Fuel Encapsulation) are shown in Table 5.15.

In the tandem fuel cycle, irradiated LWR fuel is reirradiated in HWRs without intermediate chemical reprocessing. The power recovered from a given amount of uranium is extended about $30 \%$, and the fuel discharged from the HWR contains $<0.5 \% 235 \mathrm{U}$ and about $20 \%$ less plutonium 
LEVEL 0

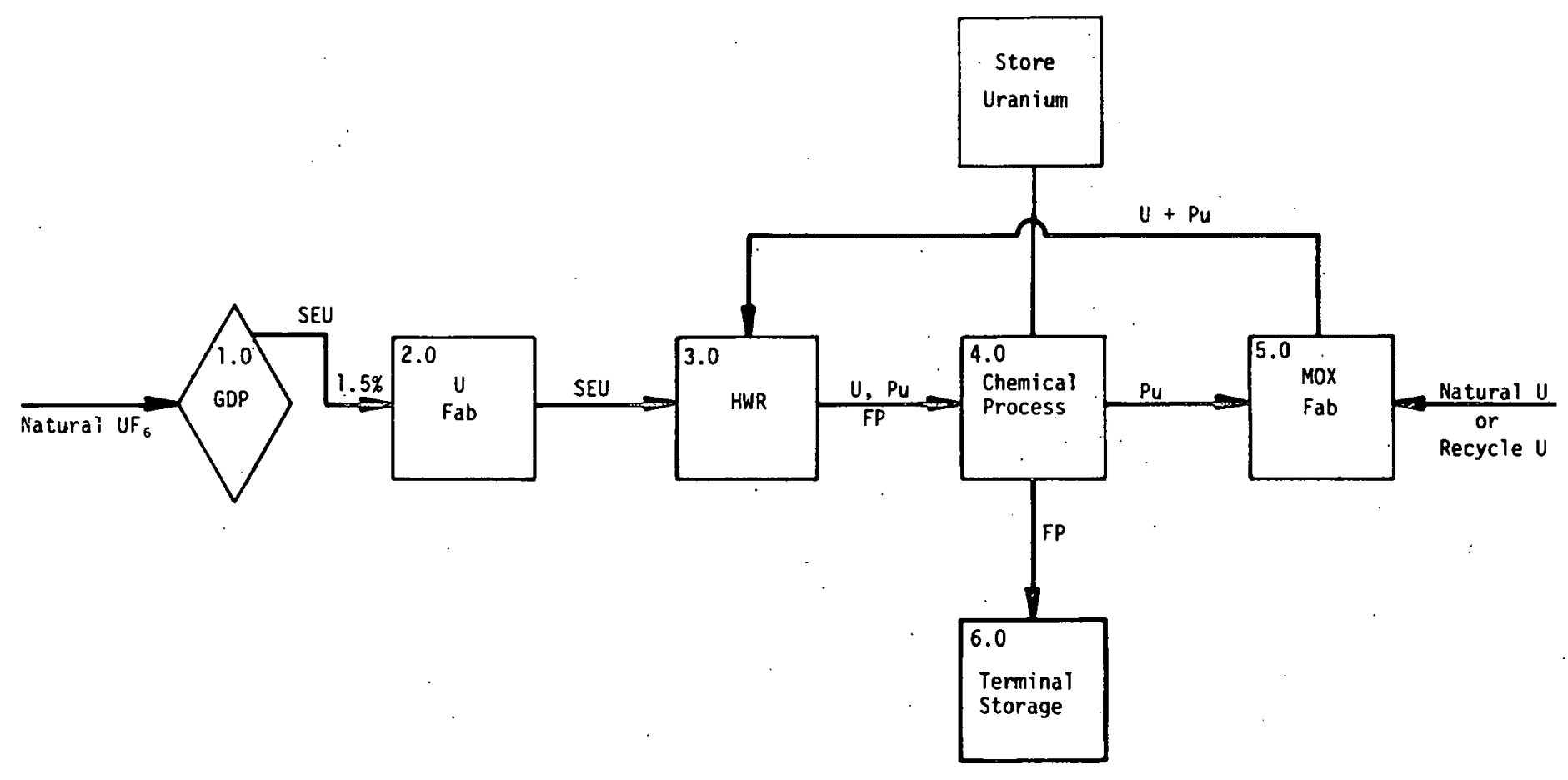

Fig. 5.38. Case 3.1.2 - Recycle of Spiked Plutonium 
LEVEL 1

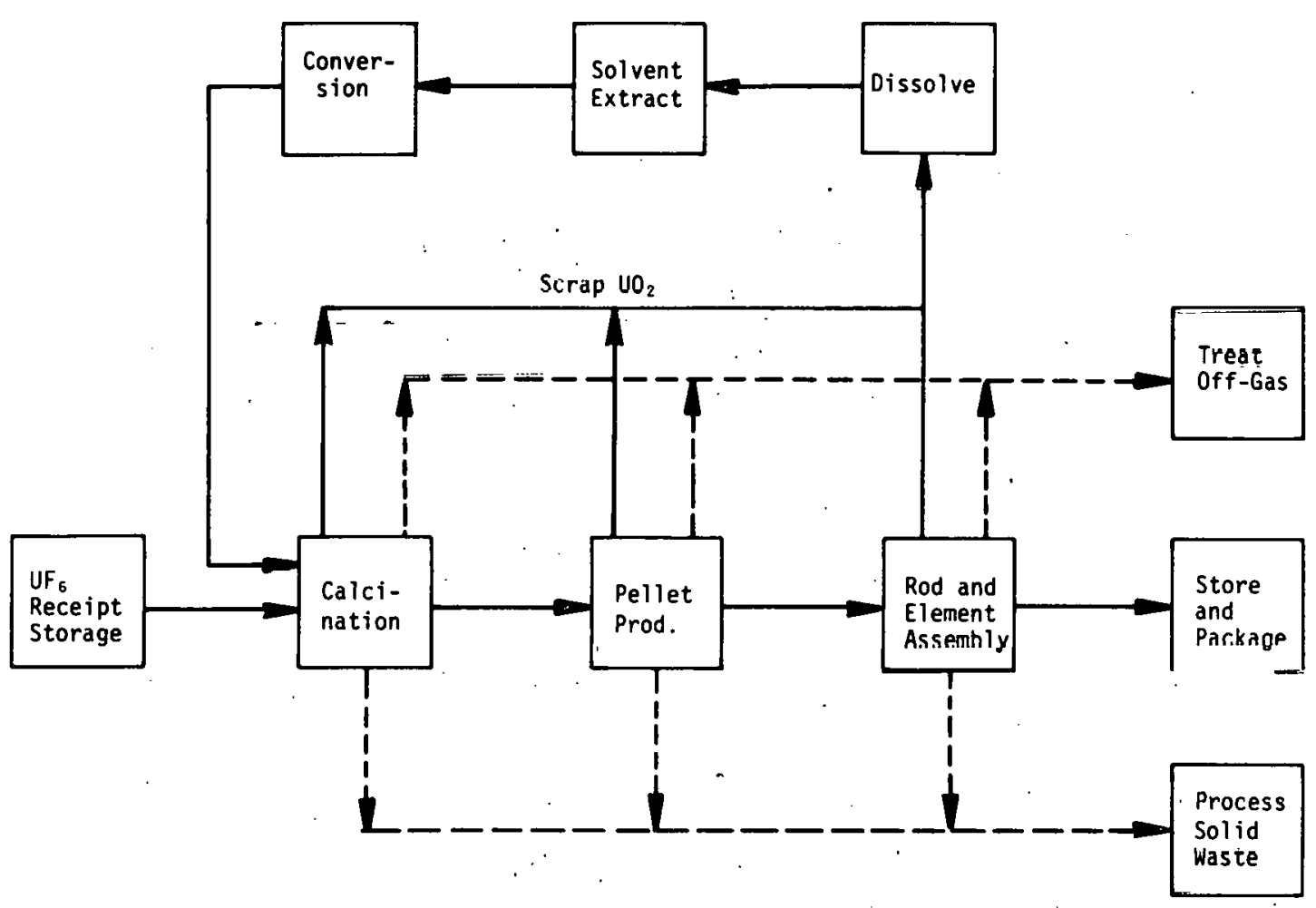

All functions are developed state of the art in Canada; radiation hazard is negligible.

Material convertibility is Category B for all steps except "Treat Off-Gas" and "Process Sol id Wacte."

Fig. 5.39. Case 3.1.2 - Recycle of Spiked Plutonium; Slightly Enriched (0.7-1.5\% $235 \mathrm{U})$ Uranium Fabrication (2.0) 


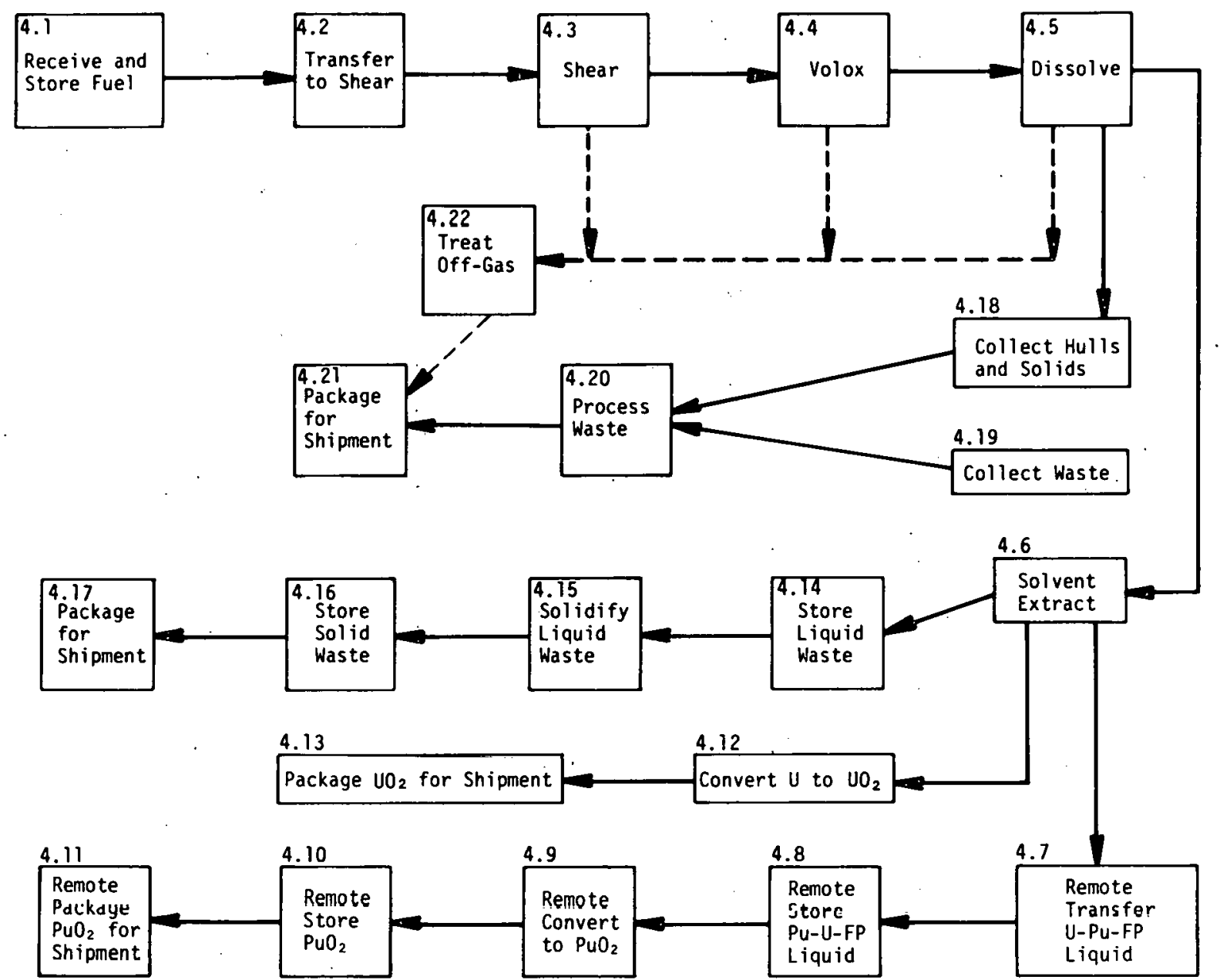

Fig. 5.40. Case 3.1.2 - Recycle of Spiked Plutonium; Chemical Reprocessing (4.0) 
LEVEL 1

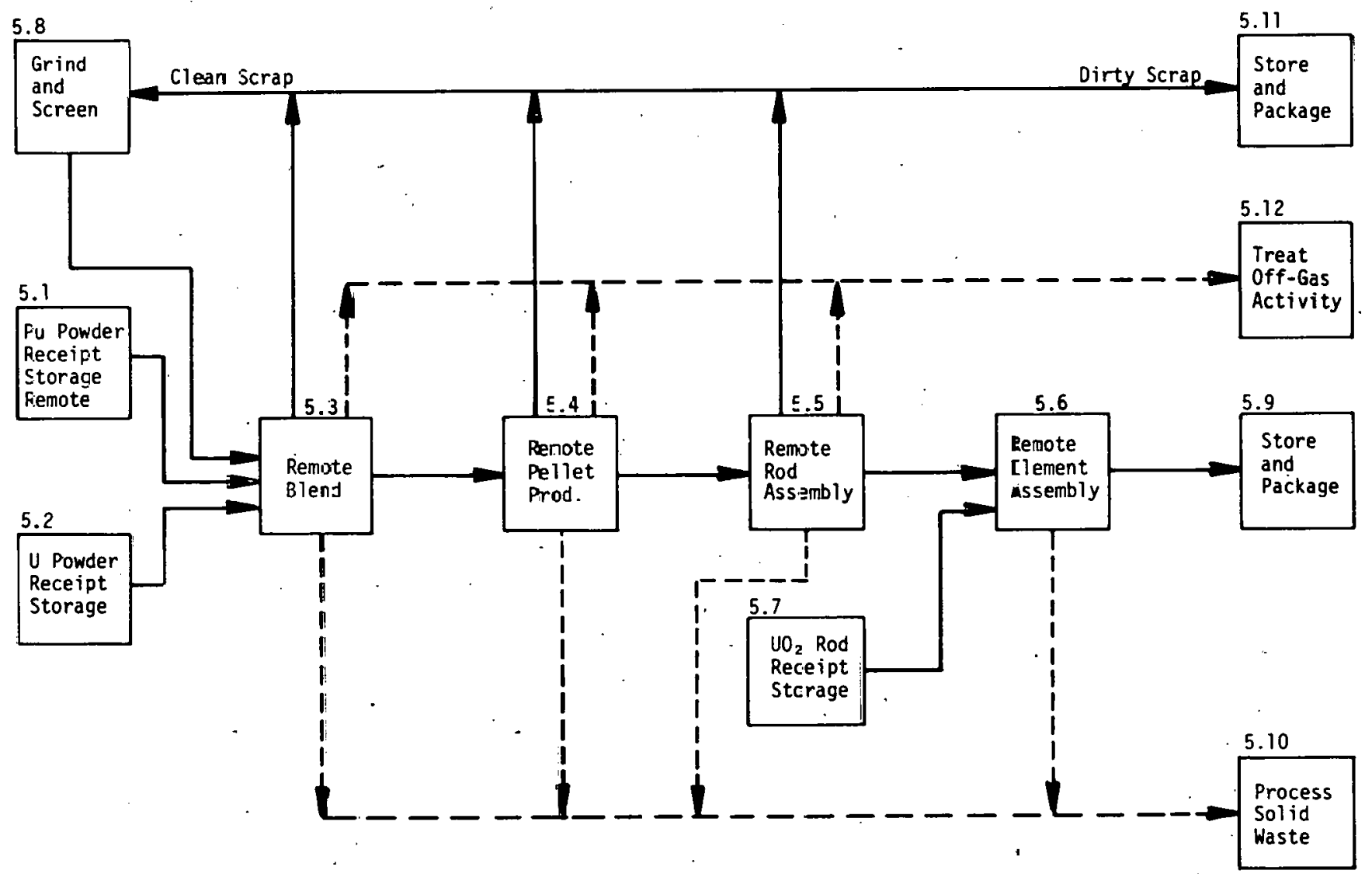

Fig. 5.41. Case 3.1.2 - Recycle of Spiked Plutonium; MOX Fabrication (5.0) 
Table 5.13. Case 3.1.2 (HWR): Recycle of Spiked Plutonfum

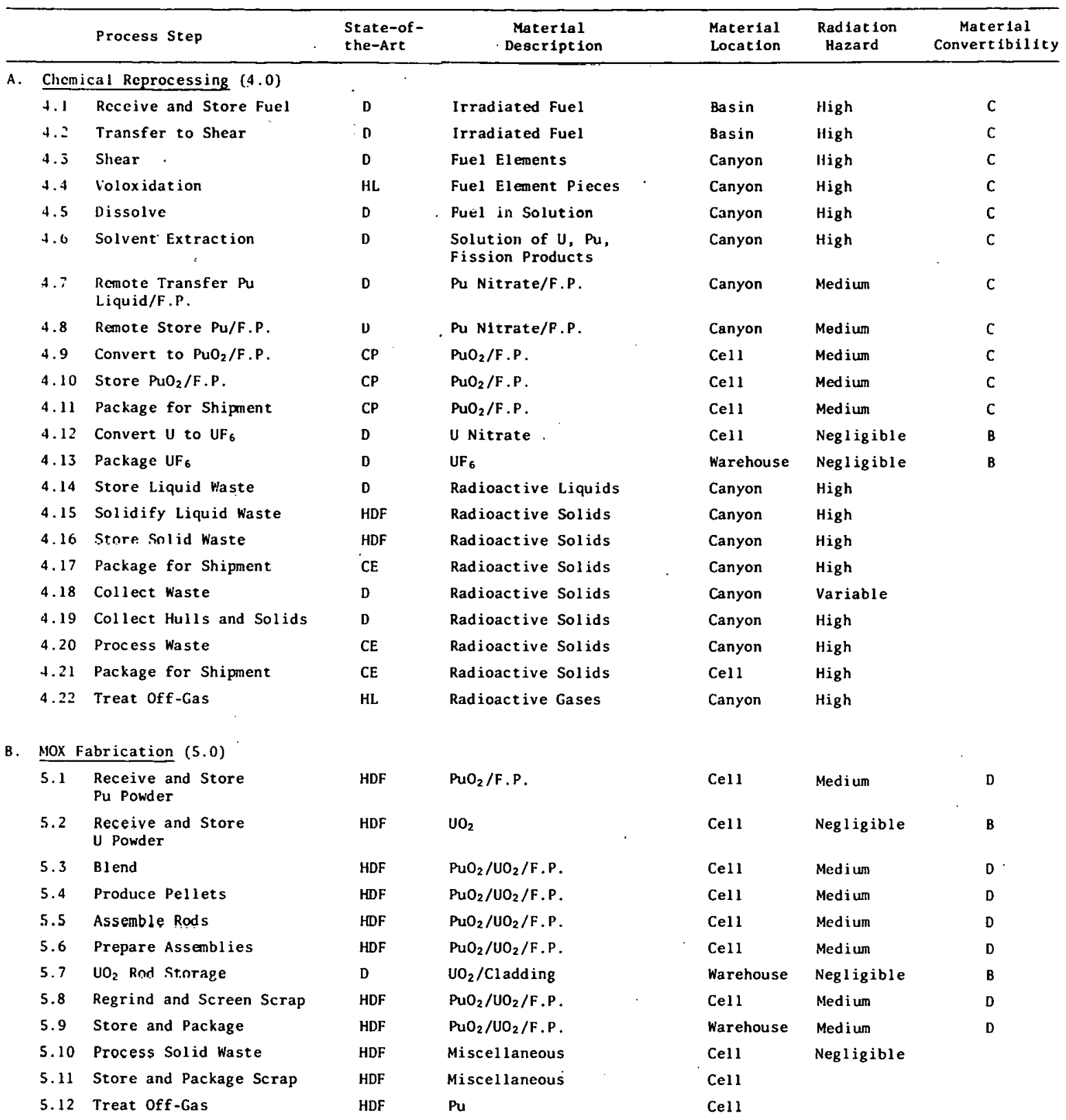


LEVEL 0

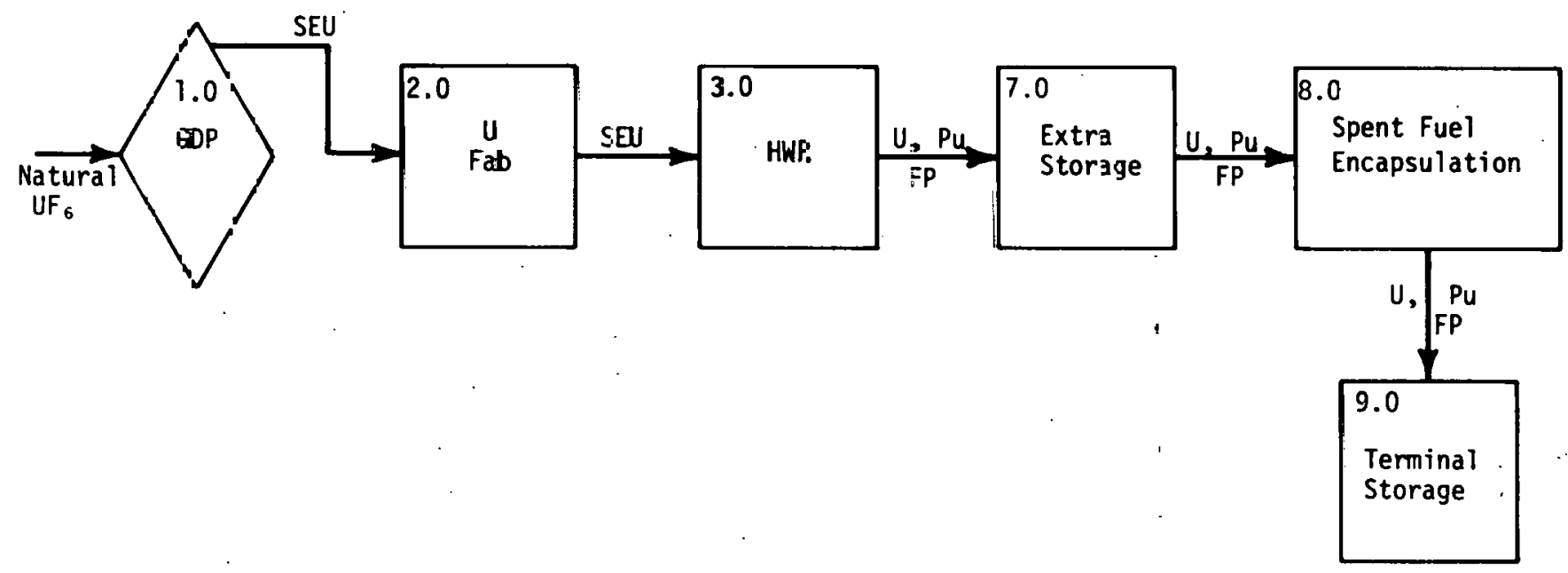

Fig. 5.42. Case 3.1.ङ - F fel Throwa'way (Oxide Fuel) 
LEVEL 1

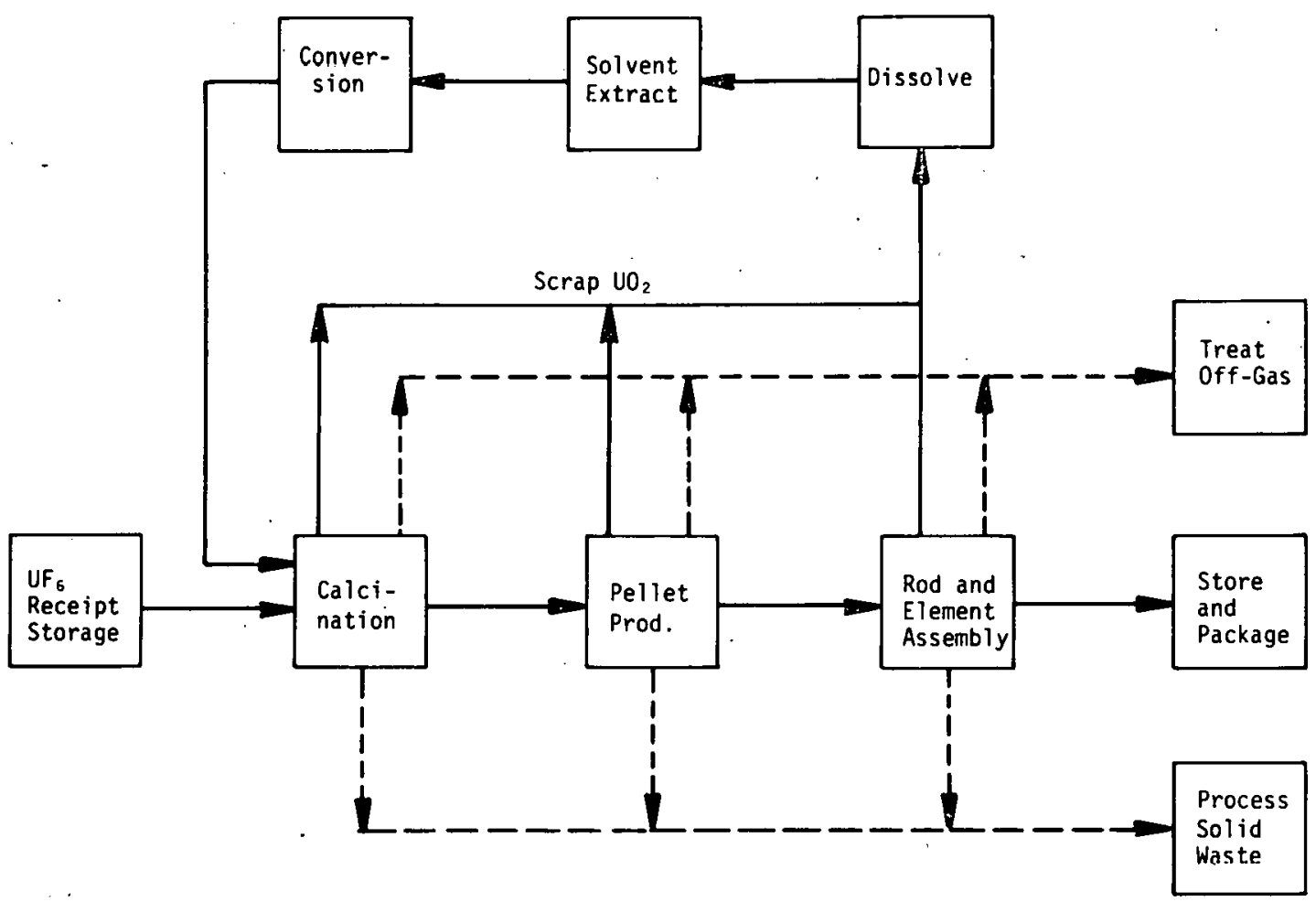

All functions are developed state-of-the-art in Canada; radiation hazard is negligible.

Material convertibility ic Category B for all steps except "Treat Off-Gas" and "Process Solid Waste."

Fig. 5.43. Case 3.1.3 - Fuel Throwaway (Oxide Fuel); Slightly Enriched $\left(0.7-1.5 \%{ }^{235} \mathrm{U}\right)$ Uranium Fabrication (2.0) 
LEVEL I

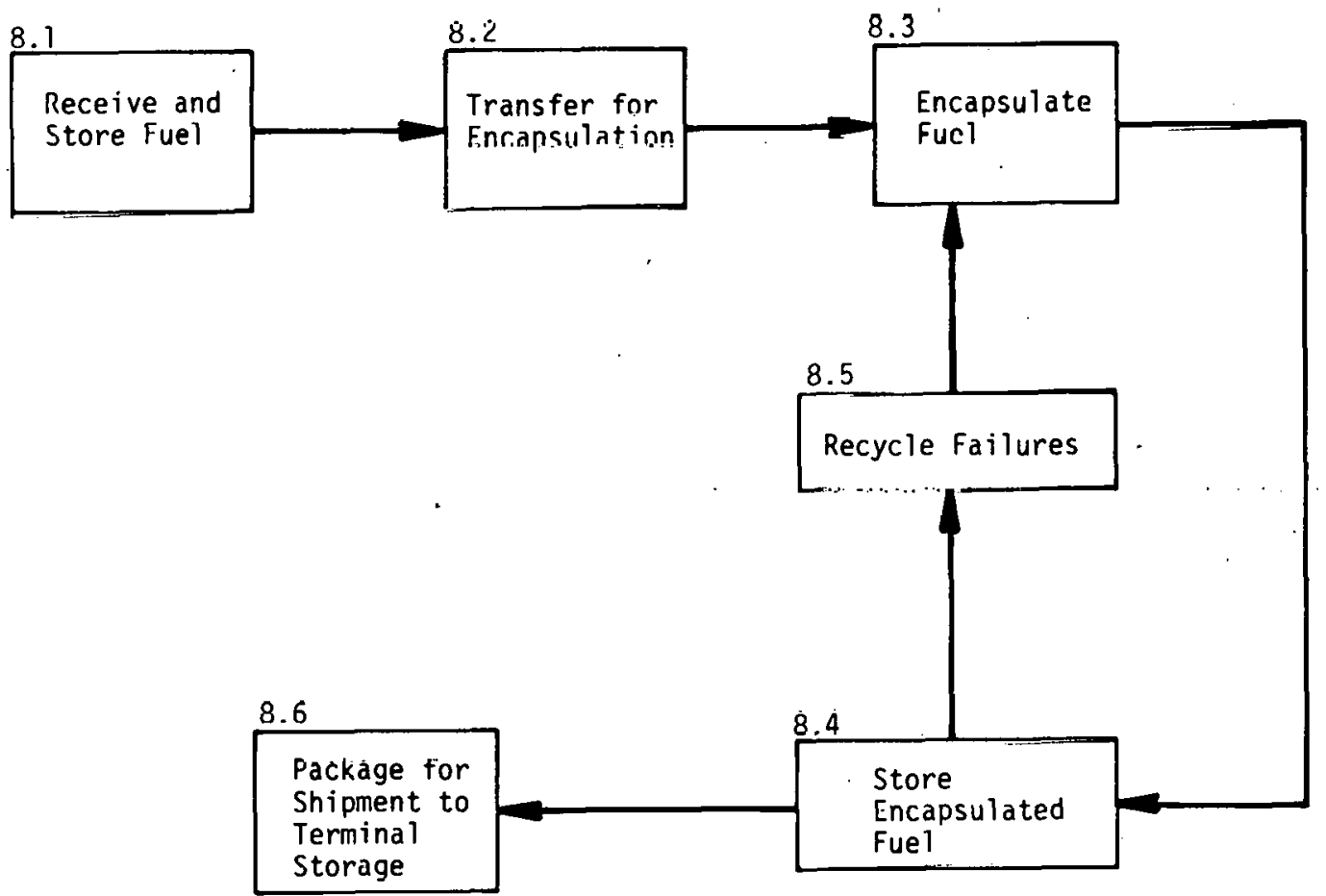

Fig. 5.44. Cáse 3.1.3 - Fuel Throwaway (Oxide Fue1); Spent Fuel Encapsulation $(8,0)$ 
Table 5.14. Case 3.1.3 (HWR): Fuel Throwaway (Oxide Fuel)

\begin{tabular}{|c|c|c|c|c|c|c|c|}
\hline & & Process Step & $\begin{array}{l}\text { State-of- } \\
\text { the-Art }\end{array}$ & $\begin{array}{l}\text { Material } \\
\text { Description }\end{array}$ & $\begin{array}{l}\text { Material } \\
\text { Location }\end{array}$ & $\begin{array}{l}\text { Radiation } \\
\text { Hazard }\end{array}$ & $\begin{array}{c}\text { Material } \\
\text { Convertibility }\end{array}$ \\
\hline \multirow[t]{7}{*}{$\wedge$. } & Enca & psulation $(8.0)$ & & & & & \\
\hline & 8.1 & Receive Fuel & D & Irrodiated IIWR Fuel & Basin & $\mathrm{High}$ & $\mathrm{C}^{\mathrm{a}}$ \\
\hline & 8.2 & Transfer to Encapsulation & D & Irradiated Fuel & Basin & High & $\mathrm{C}$ \\
\hline & 8.3 & $\begin{array}{l}\text { Encapsulate Fuel } \\
\text { Remove Gas }\end{array}$ & $s^{b}$ & Irradiated Fuel & Canyon & High & C \\
\hline & 3.4 & Store Encapsulated Fuel & D & Irradiated Fuel & $\begin{array}{l}\text { Basin or } \\
\text { Vault }\end{array}$ & $\mathrm{High}$ & $\mathrm{C}$ \\
\hline & 8.5 & Recycle Failures & $s$ & Fáiled Irradiated fuel & Canyon & $\mathrm{High}$ & $\mathrm{C}$ \\
\hline & 8.6 & $\begin{array}{l}\text { Package for Shipment to } \\
\text { Storage }\end{array}$ & $\mathrm{CE}$ & Irradiated Fuel & $\begin{array}{l}\text { Basin or } \\
\text { Vault }\end{array}$ & High & $\mathrm{C}$ \\
\hline
\end{tabular}

avaries with age of fuel.

${ }^{b}$ Some Canadian development work for CANDU fuel may be applicable. 
LEVEL 0

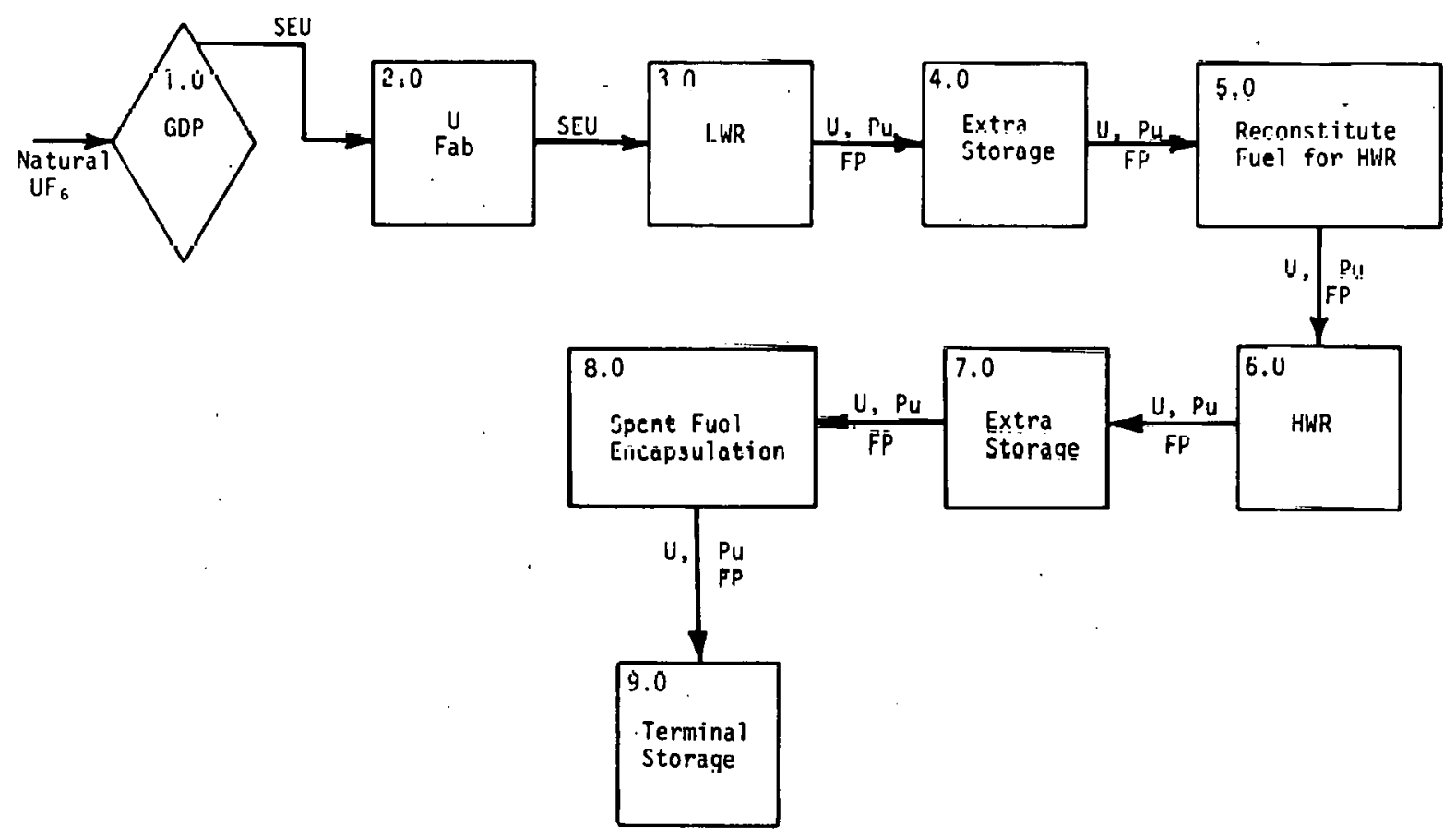

Fig. 5.45. Case 3.3.1 -. Tandern Cycle - Reconstituted LWR Fuel 


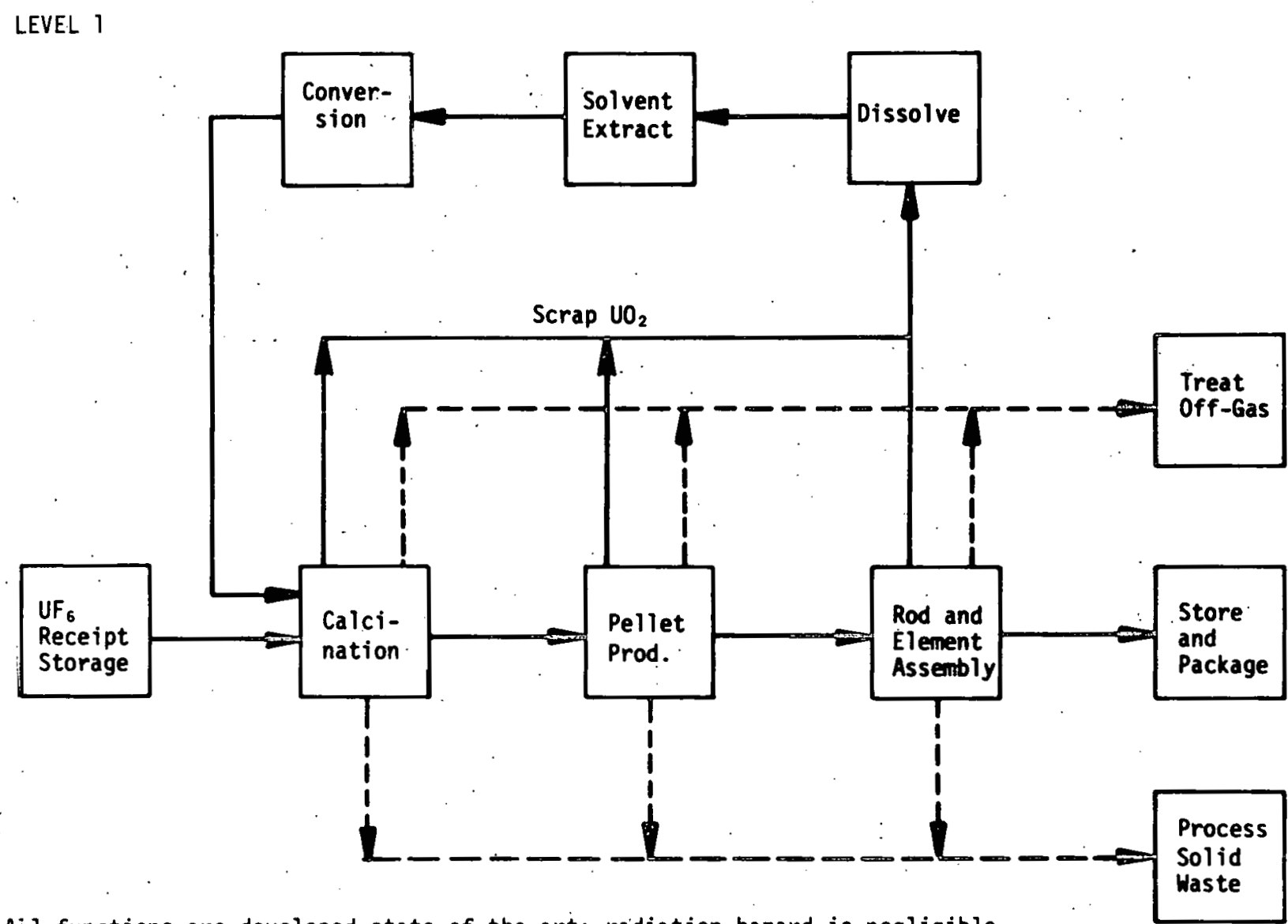

$\mathrm{Ai}_{1}$ furctions are developed state of the art; radiation hazard is negligible.

Máterial convertibility is Category B for all steps except "Treat Off-Gas" and "Process Solid Waste."

Fig. 5.46. Case 3.3.1 - Tandem Cycle with Reconstituted LWR Fuel; slightly Enriched $\left(2-4 \%{ }^{235} \mathrm{U}\right)$ Uranium Fabrication (2.0) 
LEJEL 1

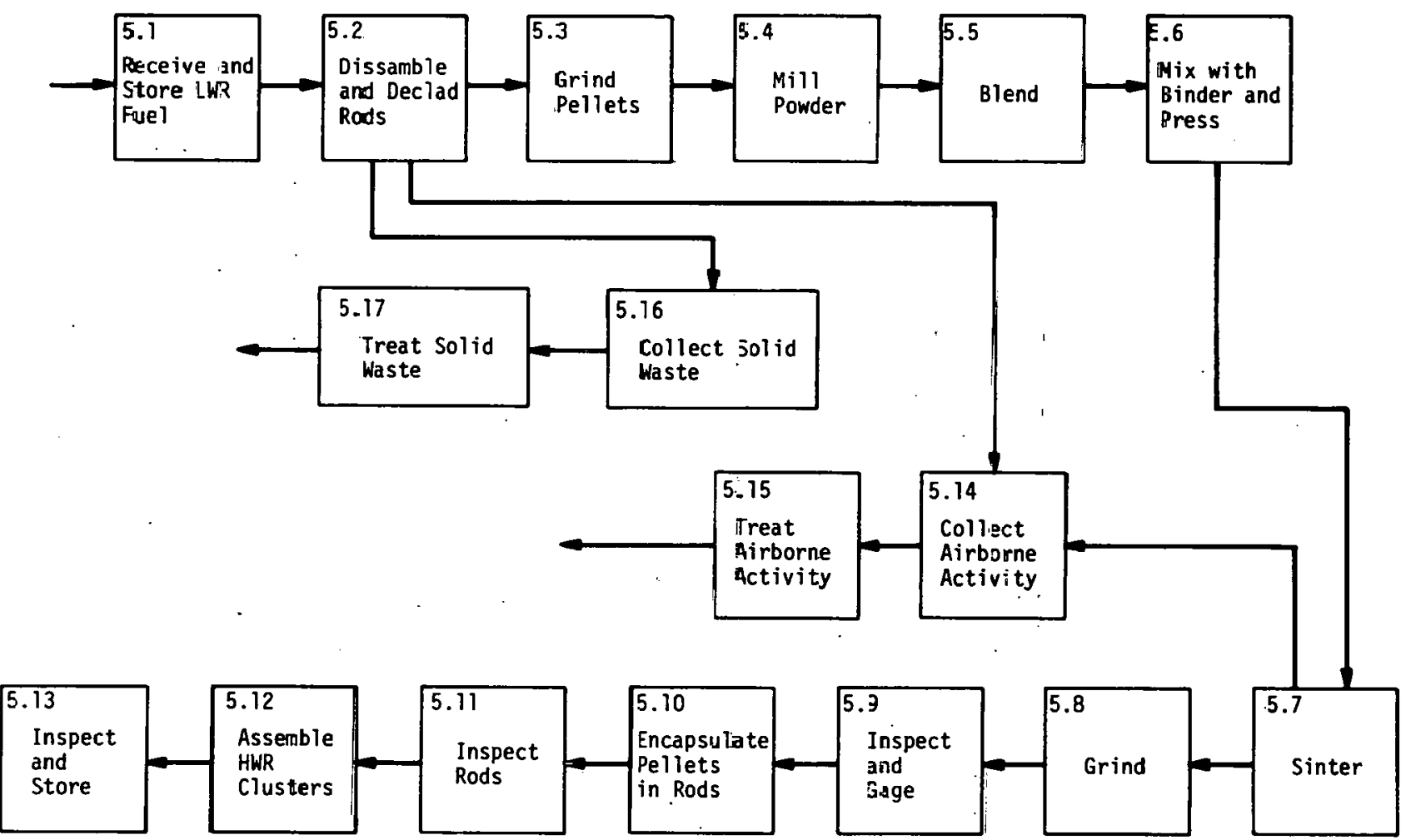

Fig. 5.47. Case 3.3.1 - Tandem Cycle witr Reconstituted LWR Fuel; Reconstitute Fuel (5.0) 
LEVEL $?$

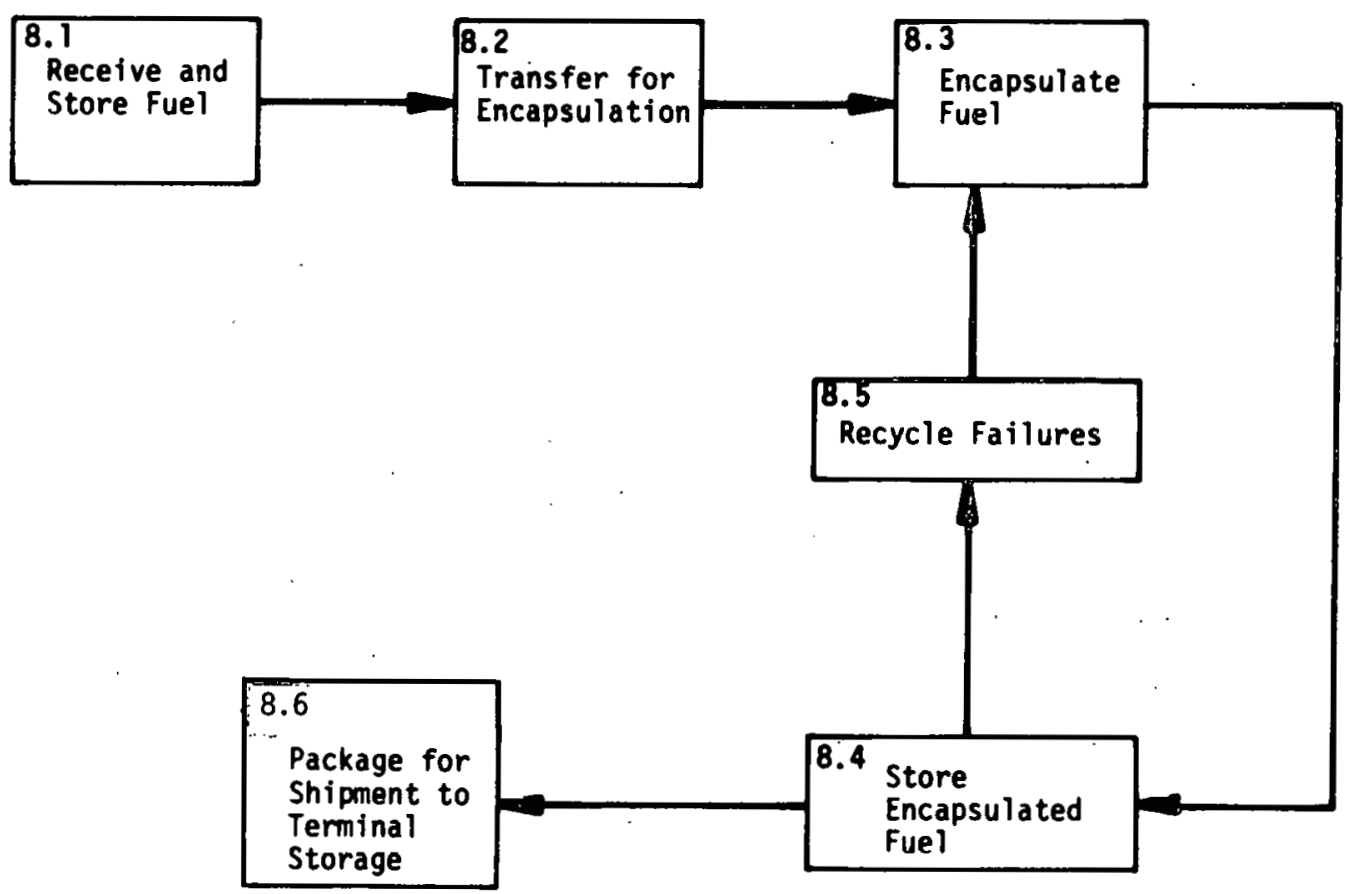

Fig. 5.48. Case 3.3.1 - Tandem Cycle with Reconstituted LWR Fuel; Spent Fuel Encapsulation (8.0) 
Table 5.15. Case 3.3.1: Tandem Cycle - Reconstituted LWR Fuel

\begin{tabular}{|c|c|c|c|c|c|c|c|c|}
\hline & & Process Step & $\begin{array}{l}\text { State-of- } \\
\text { the-Art }\end{array}$ & $\begin{array}{l}\text { Material } \\
\text { Description }\end{array}$ & $\begin{array}{l}\text { Material } \\
\text { Location }\end{array}$ & $\begin{array}{l}\text { Radiation } \\
\text { Hazard }\end{array}$ & $\begin{array}{r}\mathrm{Ma} \\
\text { Conve }\end{array}$ & $\begin{array}{l}\text { ter1al } \\
\text { rtibility }\end{array}$ \\
\hline \multirow[t]{18}{*}{ A. } & \multicolumn{8}{|c|}{ Reconstitute Fuel $(5.0)$} \\
\hline & 5.1 & $\begin{array}{l}\text { Receive and Store } \\
\text { LWR Fuel }\end{array}$ & D & Irradiated Fucl & Basin & High & & $c$ \\
\hline & 5.2 & $\begin{array}{l}\text { Dissassemble and } \\
\text { Declad Rods }\end{array}$ & HL & Irradiated Fuel & Hot Cell & $\mathrm{High}$ & & C \\
\hline & 5.3 & Frind Pellets & CL & Irradiated Fuel Pieces & Hot Cell & High & & c \\
\hline & 5.4 & Mill Powder & $\mathrm{CL}$ & $\mathrm{UO}_{2} /$ F.P. $/ \mathrm{PuO}_{2}$ & Hot Cell & High & & C \\
\hline & 5.5 & Blend Powder & $\mathbf{C L}$ & $\mathrm{UO}_{2} / \mathrm{F} . \mathrm{P} . / \mathrm{PuO}_{2}$ & Hot Cell & High & & c \\
\hline & 5.6 & Mix with Binder and Fross & CL & $\mathrm{UO}_{k} / \mathrm{F}, \mathrm{P}, / \mathrm{PuO}_{2}$ & Hot Coll & High & & r. \\
\hline & 5.7 & Sinter & CL & $\mathrm{UO}_{2} /$ F.P. $/ \mathrm{PuO}_{2}$ & Hot Cell & High & & C \\
\hline & 5.8 & Grind & CL & $\mathrm{UO}_{2} /$ F.P. $/ \mathrm{PuO}_{2}$ & Hot Cell & $\mathrm{High}$ & & c \\
\hline & 5.9 & Inspect and Gage & CP & $\amalg \mathrm{O}_{2} /$ F.P. $/ \mathrm{P}_{11 \mathrm{O}_{2}}$ & llot Cell & lligh & & C \\
\hline & 5.10 & $\begin{array}{l}\text { Encapsulate Pellets } \\
\text { in Rods }\end{array}$ & $\mathrm{CE}$ & $\mathrm{UO}_{2} / \mathrm{F} . \mathrm{P} . / \mathrm{PuU}_{2}$ & Hòt lèll & Highn & & c \\
\hline & 5.11 & Inspect Rods & $\overline{\mathrm{CE}}$ & $\mathrm{UO}_{2} / \bar{F} \cdot \bar{P} . / \overline{\mathrm{P}} \mathrm{UO}_{2}$ & Hot Cell & High & & $\mathrm{c}$ \\
\hline & 5.12 & Assemble HWR Clusters & CE & $\mathrm{Clad} \mathrm{UO}_{2} /$ F.P. $/ \mathrm{PuO}_{2}$ & Hot Cell & $\mathrm{High}$ & & C \\
\hline & 5.13 & Inspect and Store & CE & $\mathrm{Clad} \mathrm{UO}_{2} / \mathrm{F} . \mathrm{P} . / \mathrm{PuO}_{2}$ & Hot $\mathrm{Cell}$ & High & & C \\
\hline & b. 14 & Lollect Alrourne activicy & Le & 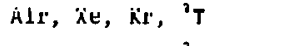 & llui cells & Luw, Val la & & \\
\hline & 5.15 & Treat Airborne Activity & $\mathrm{HL}$ & Air, $\mathrm{Xe}, \mathrm{Kr},{ }^{3} \mathrm{~T}$ & Hot Cell & Low; Varia & & \\
\hline & 5.16 & Cullect Solid Waste & $\mathrm{CE}$ & Miscellaneous & Hot Cclls & Low; Varia & & \\
\hline & 5.17 & Treat Solid Waste & $\mathrm{CE}$ & Miscellaneous & Hot Cell & Medium; Va & able & \\
\hline \multirow[t]{7}{*}{ R. } & \multicolumn{8}{|c|}{ Fncapsulation $(8.0)$} \\
\hline & 8.1 & Receive Fuel & D & Irradiated LWR Fuel & Basin & $\mathrm{High}^{\mathrm{a}}$ & & $C^{8}$ \\
\hline & 8.2 & Transfer to Encapsulation & D & Irradiated fuel & Basin & High & & c \\
\hline & 8.3 & $\begin{array}{l}\text { Encapsulate Fuel } \\
\text { Remove Gas }\end{array}$ & $s^{b}$ & Irradiated Fuel & Canyon & $\mathrm{High}$ & & c \\
\hline & 8.4 & Store Encapsulated Fuel & D & Irradiated Fuel & $\begin{array}{l}\text { Basin or } \\
\text { Vault }\end{array}$ & High & & c \\
\hline & 8.5 & Rocycle failuros & s & Failed Irradiated Fue! & Canyonn & High & & r \\
\hline & 8.6 & $\begin{array}{l}\text { Package for Shipment } \\
\text { to Storage }\end{array}$ & $\mathrm{CE}$ & Irradiated Fuel & $\begin{array}{l}\text { Basin or } \\
\text { Vault }\end{array}$ & High & & c \\
\hline
\end{tabular}

a Varies with age of fuel.

bome Canadian development work for CANDU fuel may be applicable. 
than the fuel discharged from the LWR. In this case, the LWR fuel is refabricated into a fuel form that corresponds to the normal CANDU HWR configuration. Fuel pieces for HWRs are larger than for LWRs. The refabrication step may be needed to improve the uniformity of fuel power generation during HWR exposure and to match HWR mechanical design.

A preliminary review of the tandem fuel cycle was made in Reference 1. The refabrication step is technically uncertain, and the fuel performance during extended exposure is undemonstrated. Many years of technical development would probably be required to implement the tandem fuel cycle. The incentive to recover plutonium from stored fuel would depend on the demands of a breeder reactor program. LWR fuel, HWR fuel, or tandem fuel might all contain enough plutonium to warrant processing.

\subsubsection{Case 3.3.2 (HWR): Tandem Fuel - Fuel Not Reconstituted}

Leve1 0 segments are shown in Figure 5.49; Level 1 steps, in Figures 5.50 and 5.51. The state-of-the-art and material characteristics for spent fuel encapsulation (7.0) are shown on Table 5.16.

The fuel refabrication step would not be required if a fuel design could be developed that could be used directly in HWRs after discharge from LWRs. Currently there are three PWR vendors and one BWR vendor. About 75 fuel designs have been developed, and there is very little interchangeability (only for some BWR fuel designs). Fuel enrichments are also a variable. It seems unlikely that a dual-purpose fuel design could be developed without a major compromise in fuel economy and without causing a reduction in reactor power.

\subsubsection{Case 3.4.1 (HWR): Spectral Shift Reactor - Throwaway of Oxide} Fuel (LWR-HWR Hybrid)

Level 0 segments are shown in Figure 5.52; Level 1, is shown in Figure 5.53. The state-of-the-art and material characteristics for this case are shown on Table 5.17.

The spectral shift reactor concept is based on increasing the moderating characteristics of the coolant during fuel exposure to compensate for reactivity changes. This shift in moderating characteristics is achieved by reducing the fraction of heavy water $\left(\Pi_{2} \Omega\right)$ in 
LEVEL, 0

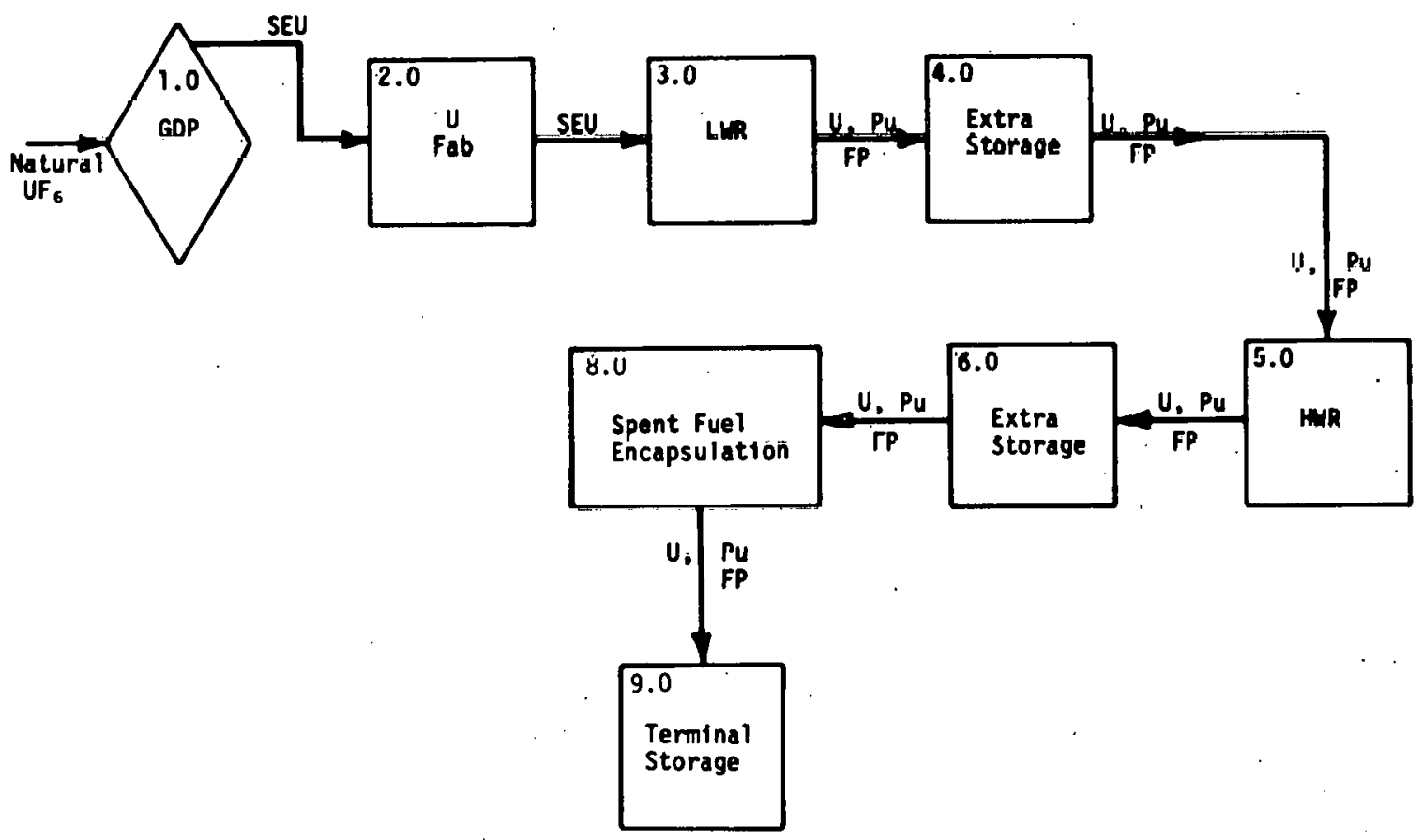

Fig. 5.49. Case 3.3.2 - Tandem Cycle - Fuel Not Reconstituted 
LEVEL 1

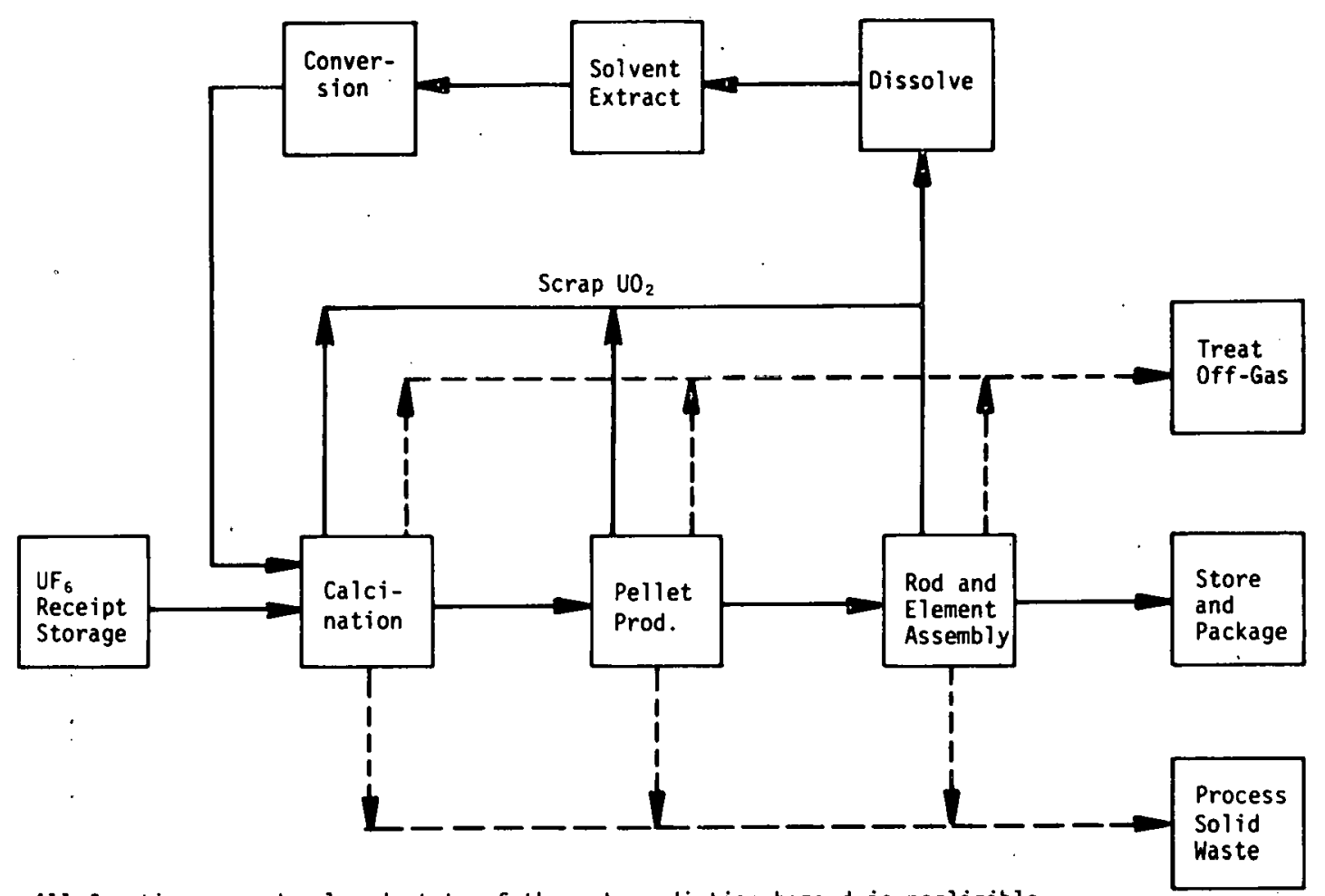

All functions are developed state of the art; radiation hazard is negligible.

Material convertibility is Category B for all steps except "Treat Off-Gas" and "Process Solid Waste."

Fig. 5.50. Case 3.3.2 - Tandem Cycle - Fuel Not Reconstituted; Slightly Enriched (2-4\% $235 \mathrm{U})$ Uranium Fabrication (2.0) 
LEVEL 1

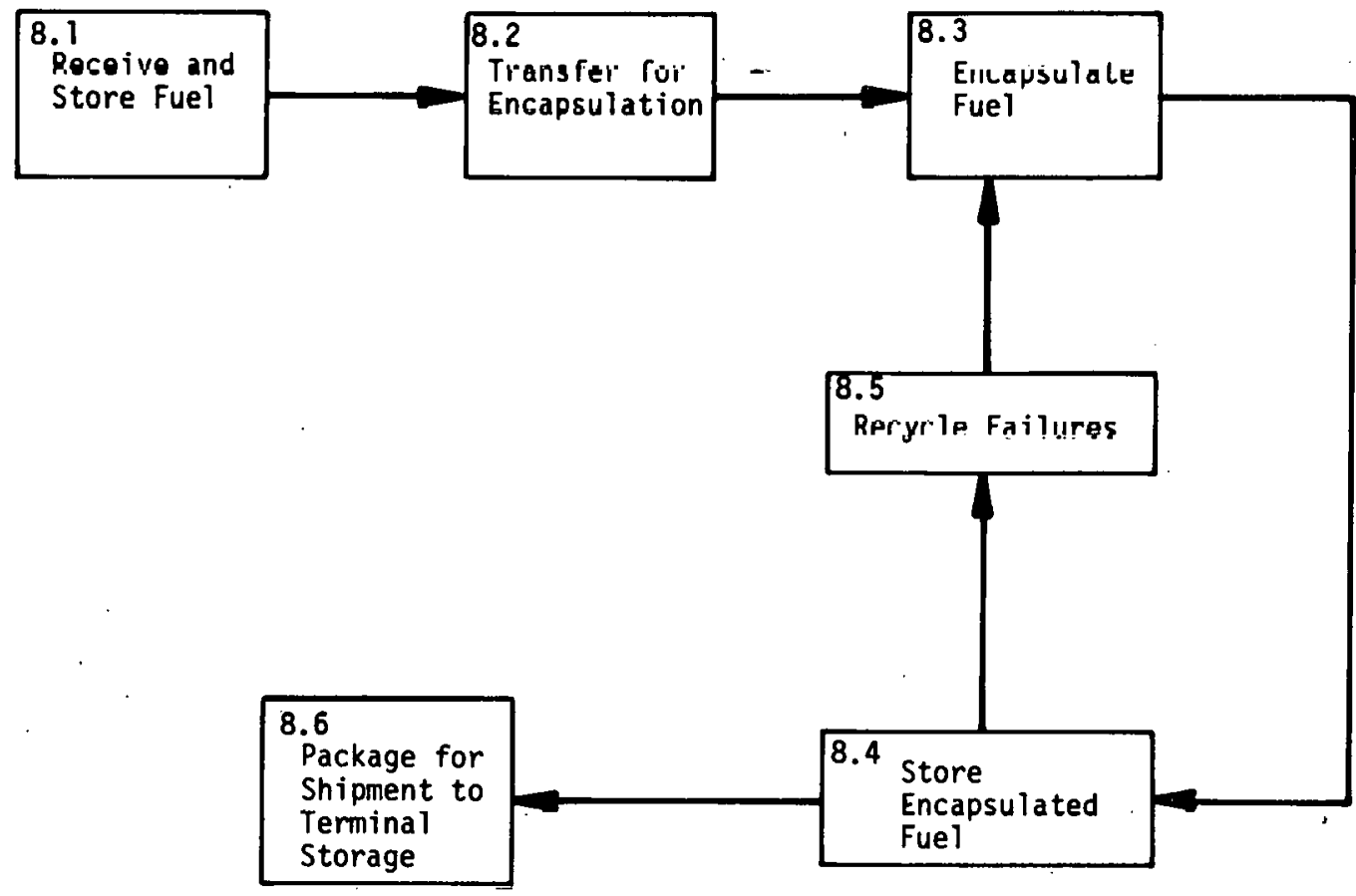

Fig. 5.51. Case 3.3.2 - Tandem Cycle - Fuel Not Reconstituted; Spent Fuel Encapsulation (8.0) 
Table 5.16, Case 3.3.2 (HWR): Tandem Cycle - Fuel Not Reconstituted; Encapsulat 1on (8.0)

\begin{tabular}{|c|c|c|c|c|c|c|c|}
\hline & & Process Step & $\begin{array}{l}\text { State-of- } \\
\text { the-Art }\end{array}$ & $\begin{array}{l}\text { Material } \\
\text { Description }\end{array}$ & $\begin{array}{l}\text { Material } \\
\text { Location }\end{array}$ & $\begin{array}{l}\text { Radiation } \\
\text { Hazard }\end{array}$ & $\begin{array}{c}\text { Material } \\
\text { Convertibility }\end{array}$ \\
\hline \multirow[t]{7}{*}{ A. } & \multicolumn{7}{|c|}{ Encapsulation (8.0) } \\
\hline & 8.1 & Receive Fuel & $\mathrm{D}$ & Irradiated LWR Fuel & Basin & $\mathrm{H}_{1} \mathrm{gh}^{\mathrm{a}}$ & $c^{a}$ \\
\hline & 8.2 & Transfer to Encapsulation & $\mathrm{D}$ & Irradiated Fuel & Basin & High & C \\
\hline & 8.3 & $\begin{array}{l}\text { Encapsulate Fuel } \\
\text { Remove Gas }\end{array}$ & $\mathrm{s}^{\mathrm{b}}$ & Irradiated Fuel & Canyon & High & C \\
\hline & 8.4 & Store Encapsulated Fuel & D & Irradiated Fuel & $\begin{array}{l}\text { Basin or } \\
\text { Vault }\end{array}$ & High & $\mathrm{C}$ \\
\hline & 8.5 & Recycle Failures & $\mathbf{s}$ & Failed Irradiated Fuel & Canyon & High & $\mathrm{c}$ \\
\hline & 8.6 & $\begin{array}{l}\text { Package for Shipment to } \\
\text { Storage }\end{array}$ & $\mathrm{CE}$ & Irradiated Fuel & $\begin{array}{l}\text { Basin or } \\
\text { Vault }\end{array}$ & High & C \\
\hline
\end{tabular}

Avaries with age of fuel.

${ }^{b}$ Some Canadian development work for CANDU fuel may be applicable. 
LEVEL 0

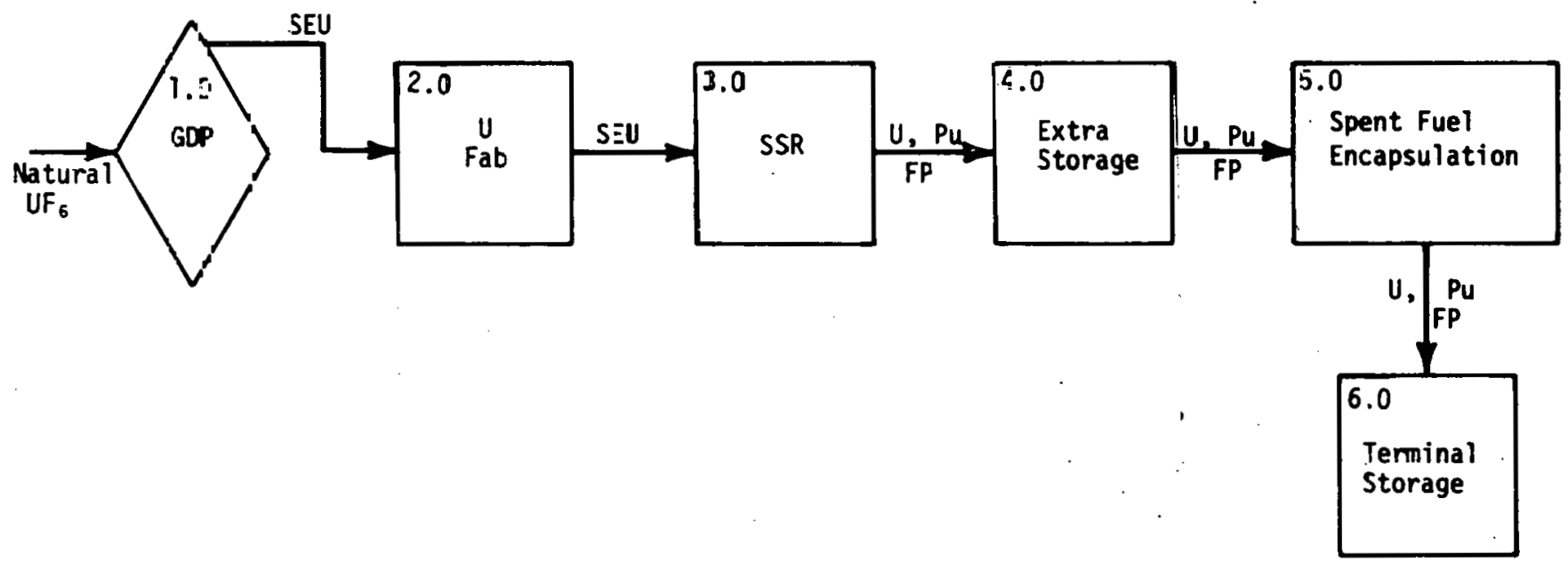

Fig. 5.5c. Case 3.4.1 - Spectral Shift Reactor (Throwawaj of Oxide Fuel) 
LEVEL 1

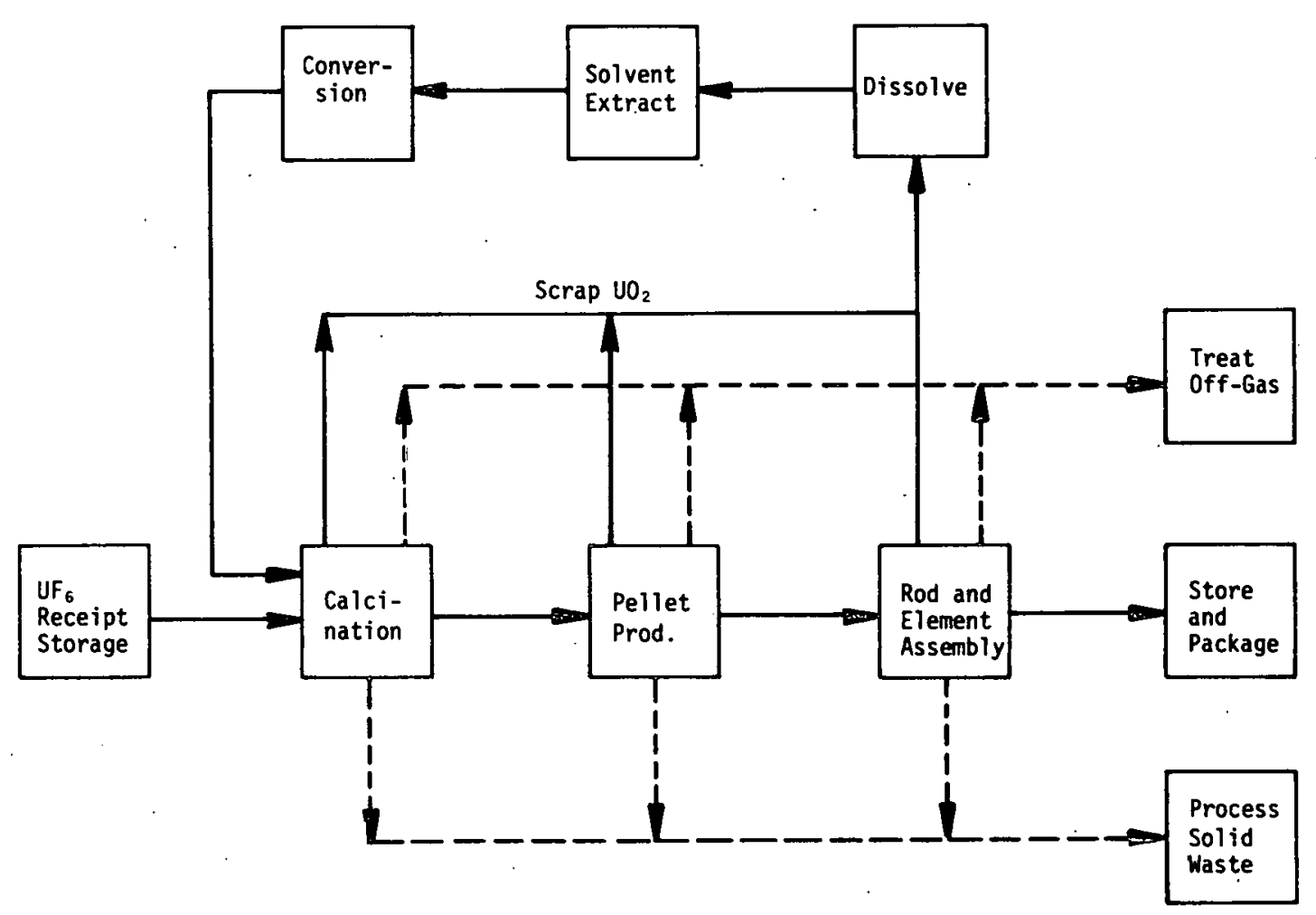

A11 functions are developed state of the art; radiation hazard is negligible.

Material convertibility is Category B for all steps except "Treat off-Gas" and "Process Solid Waste."

Fig. 5.53. Case 3.4.1 - Spectral Shift Reactor (Throwaway of Oxide Fuel); Si ightiy Enriched $\left(2.4 \%{ }^{235} \mathrm{U}\right)$ Uranium Fabrication (2.0) 
Table 5.17. Case 3.4.1 (LWR-HWR): Spectral Sh1ft Keactor (Thtuwuway - Oxide Fuel)

\begin{tabular}{|c|c|c|c|c|c|c|c|}
\hline & & Process Step & $\begin{array}{l}\text { State-of - } \\
\text { the-Art }\end{array}$ & $\begin{array}{l}\text { Material } \\
\text { Description }\end{array}$ & $\begin{array}{l}\text { Material } \\
\text { Location }\end{array}$ & & $\begin{array}{c}\text { Material } \\
\text { Convertibility }\end{array}$ \\
\hline \multirow[t]{7}{*}{ A. } & Enca & psulation (8.0) & & & & & \\
\hline & 8.1 & Receive Fuel & D & Irradiated LWR Fuel & Basin & $\mathrm{High}^{\mathrm{a}}$ & $c^{a}$ \\
\hline & 8.2 & Transfer to Encapsulation & D & Irradiated Fuel & Basin & High & $\mathrm{C}$ \\
\hline & 8.3 & $\begin{array}{l}\text { Encapsulate Fuel } \\
\text { Remove Gas }\end{array}$ & $\mathrm{s}^{\mathbf{b}}$ & Irradiated Fuel & Canyon & High & C \\
\hline & 8.4 & Store Encapsulated Fuel & D & Irradiated Fuel & $\begin{array}{l}\text { Basin or } \\
\text { Vault }\end{array}$ & High & C \\
\hline & 8.5 & Recyclc Failures & $\mathbf{s}$ & Failed Irradiated Fuel & Canyon & $\mathrm{High}$ & C \\
\hline & 8.6 & $\begin{array}{l}\text { Package for Shipment } \\
\text { to Etorago }\end{array}$ & CE & Irradiated Fuel & $\begin{array}{l}\text { Basin or } \\
\text { Vault }\end{array}$ & High. & C \\
\hline
\end{tabular}

avaries with age of fuel.

bome Canadian development work for CANDU fuel may be applicable. 
the coolant from 60 to $10 \%$ during a fuel cycle, so that the spectrum approaches that of the LWR-PWR. This mode of operation has the advantage of reducing the amount of enrichment needed from 3.2 to 2.6 wt $\%{ }^{235} \mathrm{U}$ in the oxide fuel and eliminates the necessity of using boron as a chemical shim for reactivity control in a PWR. B\&W once attempted to market the spectral shift reactor.

If the same fuel exposure is attained (by producing more ${ }^{239} \mathrm{Pu}$ fuel by resonance absorption with the spectral shift reactor concept), a resource savings of about $20 \%$ is attainable without reprocessing. It is not clear that annual fuel reloadings are compatible with the spectral shift mode. The details of adjusting the coolant concentration should be carefully reviewed. The conversion from $10 \%$ to $60 \% \mathrm{D}_{2} 0$ would probably require a significant inventory of $\mathrm{D}_{2} \mathrm{O}$ which, in addition to facilities for upgrading the discharged coolant, would increase the capital cost of the spectral shift concept.

\subsubsection{Case 7.1.1 (Energy Center - LWR): Combination of Fuel Cycles with Internal Control of Plutonium}

Level 0 segments are shown in Figure 5.54; Level 1 steps, in figures $5.55,5.56,5.57$ and 5.58. The state-of-the-art and material characteristics for chemical processing (4.0), MOX fabrication (5.0) and spent fuel encapsulation (8.0) arc shown in Table 5.18 .

Light water reactors fueled with uranium-plutonium would be operated inside the energy center for internal control of the plutonium. Uraniumfueled LWRs would be operated outside the energy center. All irradiated fuel from outside the energy center could be shipped into the energy center for internal processing and eventual use if the reactor capacity in the center were large enough. About $30 \%$ of the total LWR power would have to be located within the energy center. The flexibility shown in the diagram implies some shipment of fuel to terminal storage as if the energy center does not have sufficient capacity. 
LEVEL 0

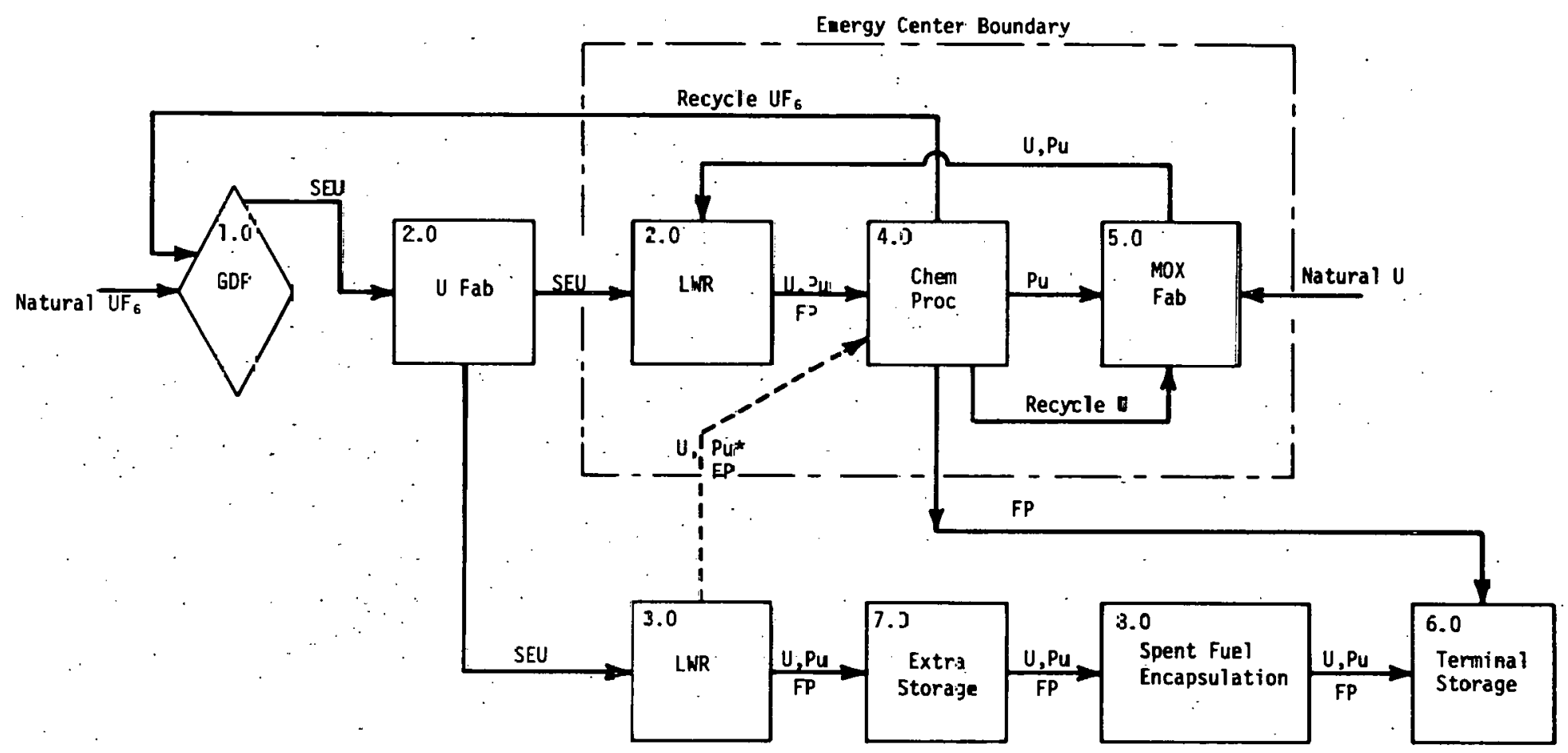

*Util:zat:on of outs:de fuel depends on relative number of reactors inside and outside of parks.

Fig. 5.54. Case 7.1.1 - Energy Center; Internal Control of Plutonium 


\section{LEVEL 1}

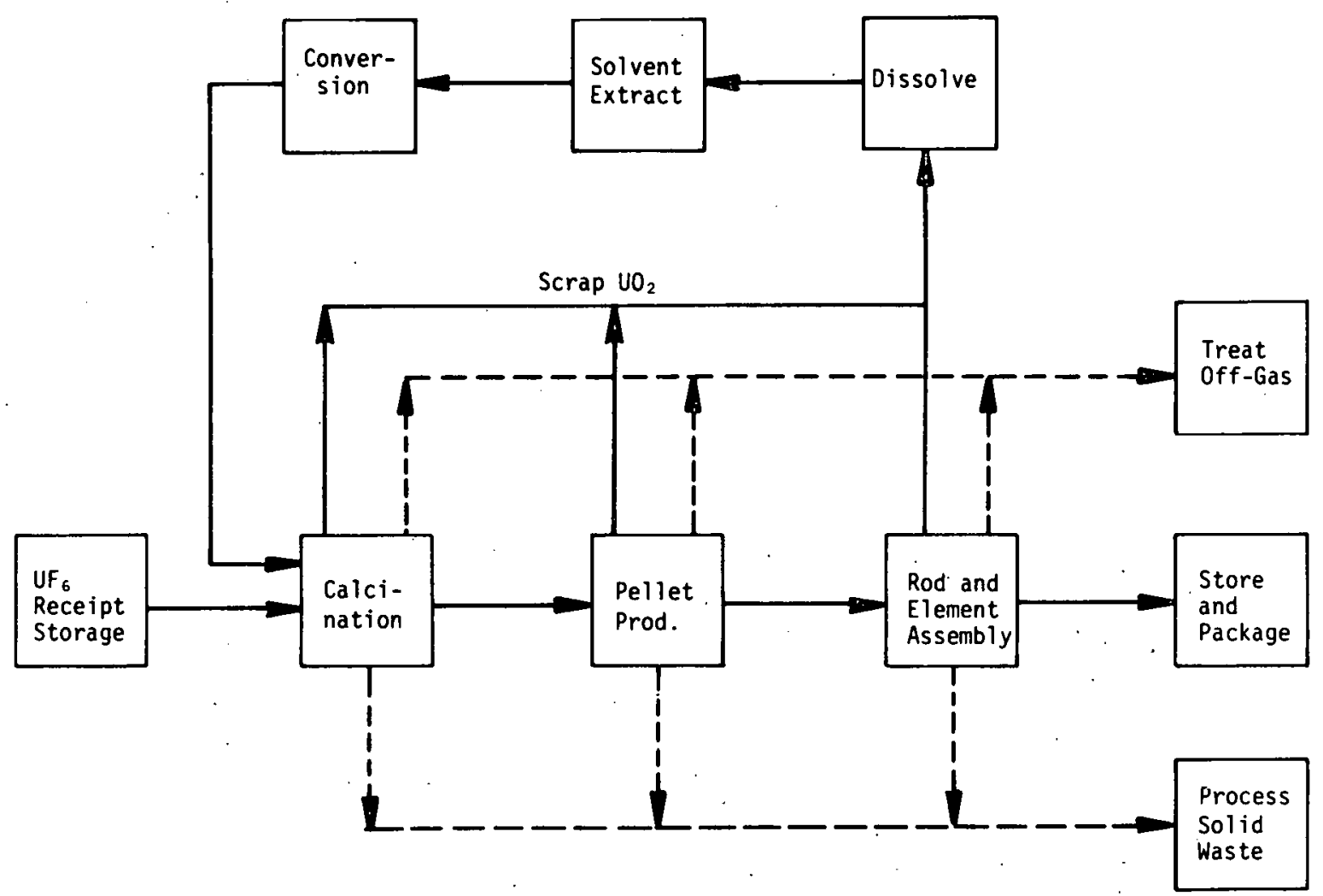

All functions are developed state of the art; radiation hazard is negligible.

Material convertibility is Category $B$ for all steps except

"Treat Off-Gas" and "Process Sol id Waste."

Fig. 5.55. Case 7.1.1-Energy Center; Slightly Enriched $\left(2-4 \%{ }^{2} 35 \mathrm{U}\right)$ Uranium Fabrication (2.0) 
LEVEL 1

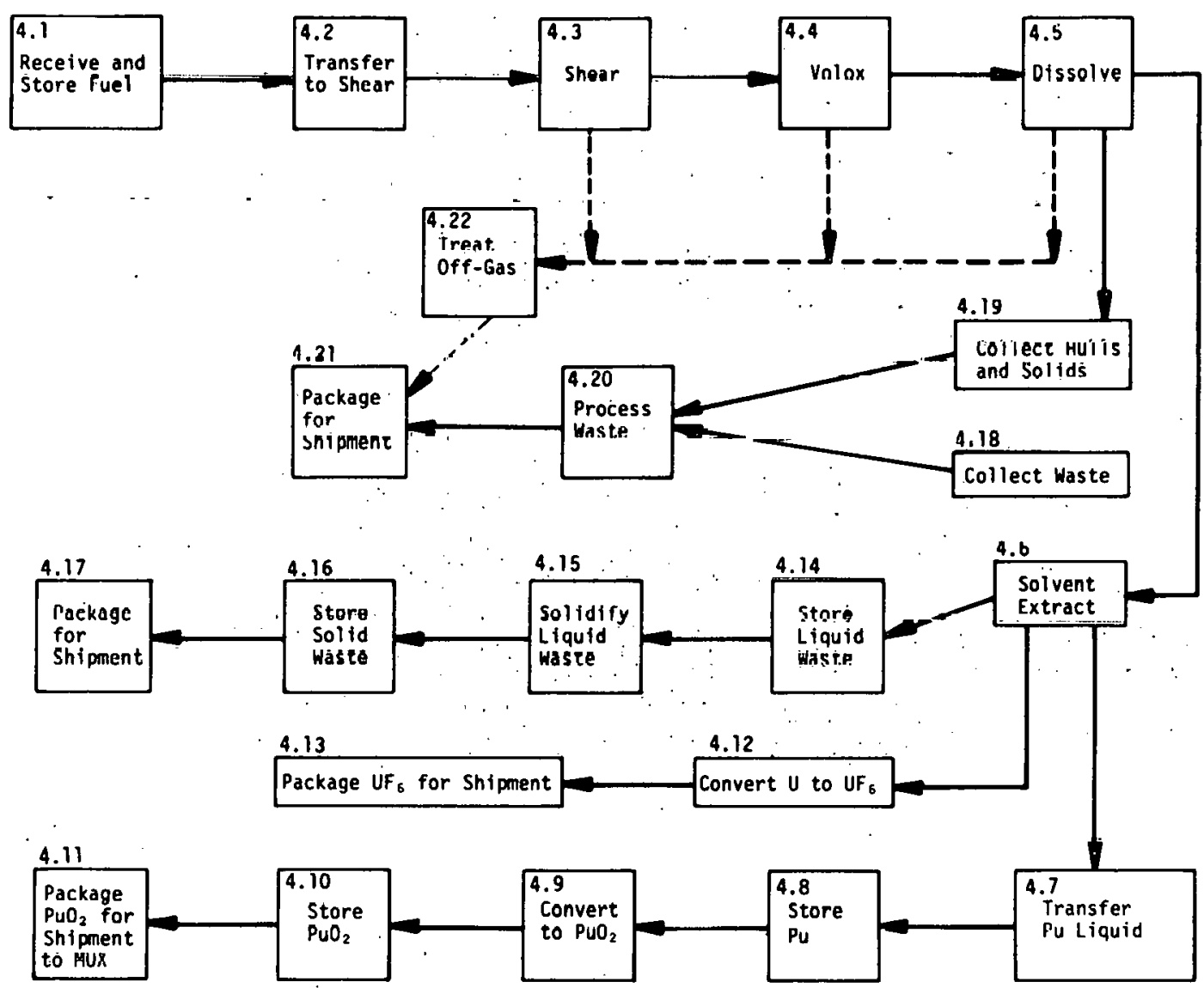

Fig. 5.56. Case 7.1.1 - Energy Center; Chemical Reprocéssing (4.0) 


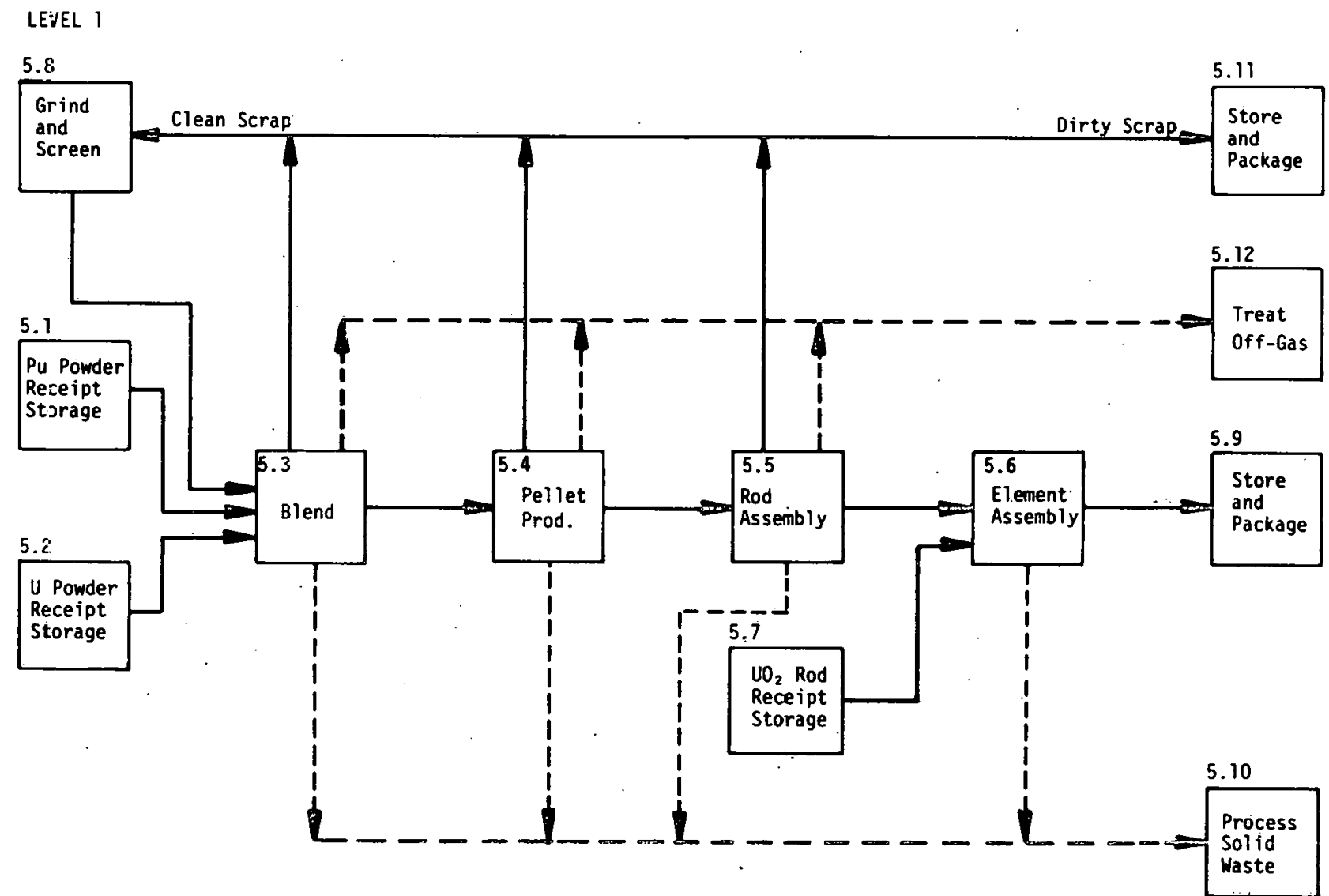

Fig. 5.57. Case 7.1.1 - Energy Center; MoX Fabrication (5.0) 
LEVEL I

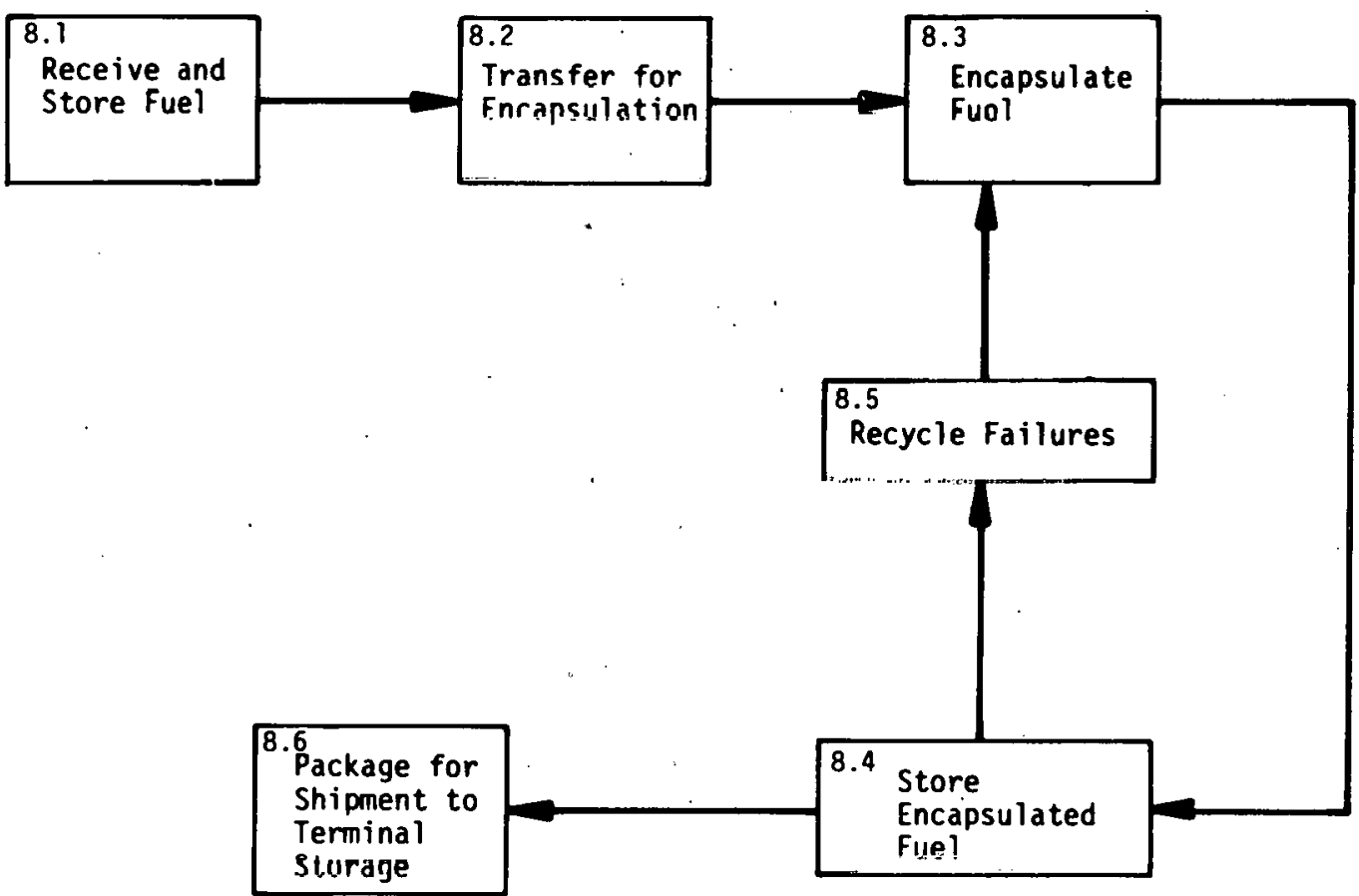

Fig. 5.58. Case 1.1.1 =- Energy Cenler; Spent Fuel Encapsulation (8.0) 
Table 5.18. Case 7.1.1 (LWR Energy Center): Internal Recycle of Plutonfum

\begin{tabular}{|c|c|c|c|c|c|c|c|}
\hline & & Process Step & $\begin{array}{l}\text { State-of } \\
\text { the-Art }\end{array}$ & $\begin{array}{l}\text { Material } \\
\text { Description }\end{array}$ & $\begin{array}{l}\text { Material } \\
\text { Location }\end{array}$ & $\begin{array}{l}\text { Radiation } \\
\text { Hazard }\end{array}$ & $\begin{array}{c}\text { Material } \\
\text { Convertibility }\end{array}$ \\
\hline \multirow[t]{23}{*}{$\wedge$. } & \multicolumn{7}{|c|}{ Chemical Reprocessing ( 4.0 ) } \\
\hline & 4.! & Receive and Store fuel & $\mathbf{D}$ & Irradiated ruel & Basin & High & C \\
\hline & 4.2 & Transfer to Shear & D & Irradiated Fuel & Basin & High & $C^{\prime}$ \\
\hline & 4.3 & Shear & D & Fuel Elements & Canyon & High & C \\
\hline & 4.4 & Voloxidation & HL & - Fuel Element Pieces & Canyon & $\mathrm{High}$ & C \\
\hline & 4.5 & Dissolve & D & Fuel in Solution & Canyon & $\mathrm{High}$ & C \\
\hline & 4.6 & Solvent Extraction & D & $\begin{array}{l}\text { Solution of } U \text {, Pu, } \\
\text { Fission Products }\end{array}$ & Canyon & High & C \\
\hline & 4.7 & Transfer Pu Liquid & D & $\because$ Pu Nitrate & Canyon & Low & D \\
\hline & 4.8 & Store Pu & D & Pu Nitrate & Canyon & Low & D \\
\hline & 4.9 & Convert to $\mathrm{PuO}_{2}$ & $\mathrm{HE}$ & $\mathrm{PuO}_{2}$ & Cell & Low & D \\
\hline & 4.10 & Store $\mathrm{PuO}_{2}$ & D & $\mathrm{PuO}_{2}$ & Cell & Low & D \\
\hline & 4.11 & Package for Shipment & D & $\mathrm{PuO}_{2}$ & Cell & Low & D \\
\hline & 4.12 & Convert $U$ to $U F_{6}$ & D & U Nitrate & Cell & Negligible & B \\
\hline & 4.13 & Package $U_{6}$ & D & $\mathrm{UF}_{6}$ & Warehouse & Negligible & B \\
\hline & 4.14 & Store Liquid Waste & $\mathrm{D}$ & Radioactive Liquids & Canyon & $\mathrm{High}$ & 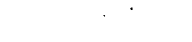 \\
\hline & 4.15 & Solidify Liquid Waste & HDF & Radioactive Solids & Canyon & High & \\
\hline & 4.16 & Store Solid Waste & HDF & Radioactive Solids & Canyon & High & \\
\hline & 4.17 & Package for Shipment & $\mathrm{CE}$ & Radioactive Solids & Canyon & $\mathrm{High}$ & \\
\hline & 4.18 & Collect Waste & D & Radioactive Solids & Canyon & Variable & \\
\hline & 4.19 & Collect Hulls and Solids & D & Radioactive Solids & Canyon & High & \\
\hline & 4.20 & Process Waste & $\mathrm{CE}$ & Radioactive Solids & Canyon & High & \\
\hline & 4.21 & Package for Shipment & $\mathrm{CE}$ & Radioactive Solids & Cell & High & \\
\hline & 4.22 & Treat of $\dot{f}-$ Gas & HL & Radioactive Gases & Canyon & High & \\
\hline B. & \multicolumn{7}{|c|}{ Mox Fabrication (5.0) } \\
\hline & 5.1 & Receive and Store Pu Powder & HDF & $\mathrm{PuO}_{2}$ & Cell & Low & D \\
\hline & 5.2 & Receive and Store U Powder & HDF & $\mathrm{UO}_{2}$ & Cell & Negligible & B \\
\hline · & 5.3 & Blend & HDF & $\mathrm{PuO}_{2} / \mathrm{UO}_{2}$ & Cell & Low & D \\
\hline & 5.4 & Produce Pellets & HDF & $\mathrm{PuO}_{2} / \mathrm{UO}_{2}$ & Cell & Low & $\mathbf{D}$ \\
\hline & 5.5 & Assemble Rods & HDF & $\mathrm{PuO}_{2} / \mathrm{IOO}_{2} / \mathrm{Clada}$ ang & Cell & Low & D \\
\hline & 5.6 & Prepare Assemblies & HDF & $\mathrm{PuO}_{2} / \mathrm{UO}_{2} / \mathrm{Cladding}$ & $\mathrm{Cell}$ & Low & $\mathrm{D}$ \\
\hline & 5.7 & $\mathrm{UO}_{2}$ Rod Storage & D & $\mathrm{UO}_{2} /$ Cladding & Warehouse & Negligible & $\mathrm{B}$ \\
\hline & 5.8 & Regrind and Screen Scrap & . $\mathrm{HDF}$ & $\mathrm{PuO}_{2} / \mathrm{UO}_{2}$ & $\mathrm{Cell}$ & Low & D \\
\hline & 3.9 & Slure and Package & HDF & $\mathrm{PuO}_{2} / \mathrm{UO}_{2}$ & Warehuuse & Luw & D \\
\hline & 5.10 & Process Solid Waste & HDF & Miscellaneous & Cell & Negligible & \\
\hline & 5.11 & Store and Package Scrap & HDF & Miscellaneous & Cell & & \\
\hline & 5.12 & Treat off-Gas & $\mathrm{HDF}$ & $\mathrm{Pu}$ & Cell & & \\
\hline \multirow[t]{7}{*}{ c. } & \multicolumn{2}{|c|}{ Encapsulation (8.0) } & . & . & & & . \\
\hline & 8.1 & Receive Fuel & D & Irradiated LWR Fuel & Basin & $\mathrm{High}^{\mathrm{a}}$ & $c^{a}$ \\
\hline & 8.2 & Transfer to Encapsulation & D & Irradiated Fuel & Basin & High & C \\
\hline & 8.3 & $\begin{array}{l}\text { Encapsulate Fuel } \\
\text { Remove Gas }\end{array}$ & $\mathbf{s}^{\mathbf{b}}$ & Irradiated Fuel & Canyon & High & C \\
\hline & 8.4 & Sture Eicapsulated Puel & D & Irradialed Puel & $\begin{array}{l}\text { Basin ur } \\
\text { Vault }\end{array}$ & High & $\mathrm{c}$ \\
\hline & 8.5 & Recycle Failures & $\mathbf{s}$ & Failed Irradiated Fuel & Canyon & High & C \\
\hline & 8.6 & $\begin{array}{l}\text { Package for Shipment } \\
\text { to Storage }\end{array}$ & $\mathrm{CE}$ & Irradiated Fuel & $\begin{array}{l}\text { Basin or } \\
\text { Vault }\end{array}$ & High & $\mathrm{C}$ \\
\hline
\end{tabular}

aaries with age of fuel.

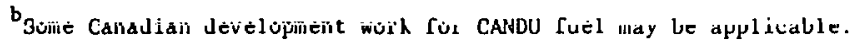




\subsection{PROCESSING SIDESTREAMS}

Normal processing sequences for the 16 alternative fuel cycles analyzed by SRL are shown in the previous figures and tables. However, the ease of diverting fissionable material into a sidestream for special processing and conversion into weapons is also of interest in this study. The ease of modifying a process to recover the fissionable material in a more convenient form will also be studied. A preliminary description of such sidestream processing to recover plutonium is given in Table 5.19 for the SRL cases. Sidestream processing for some cases will be studied in more detail in Phase 2. The cases are listed in order of increasing difficulty; however, the degree of difficulty is judged to be minor.

Recovery of plutonium from a solution can be accomplished by precipitation or ion exchange. as well as the large-scale industrial separation methods (mixer-settlers, pulse columns, etc.). Radiation provides some interference with processing, but is only a minor complication in a nationally planned program of recovery.

\subsection{SPIKING P̈LUTOÓNIIUM}

Cases $1.1 .2,1.1 .3$, and 3.1 .2 require that plutonium streams contain a source of high radiation to serve as a deterrent to diversion of plutonium for unauthorized purposes. Some relationship between the radiation level and resistance to sidestream diversion (to proliferation) may be developed in future work to aid in determining a suitable processing method. Preliminary consideration of spiking plutonium assumes plutonium containing the residual fission products after one cycle of solvent extraction will be adequately spiked. Calculations by the SRL Reactor Physics Division indicate the radiation level in the spiked plutonium is about ten-fold higher than in purified plutonium, because an effective DF of 5000 is calculated for the first cycle of solvent extraction. 'l'hus, the spiked plutonium would emit more than several $\mathrm{R} / \mathrm{hr} / \mathrm{kg}$. It would be necessary to decrease the effectiveness of the Purex process if a further increase in radiation is warranted. 
Table 5.19. Diversion of Sidestreams

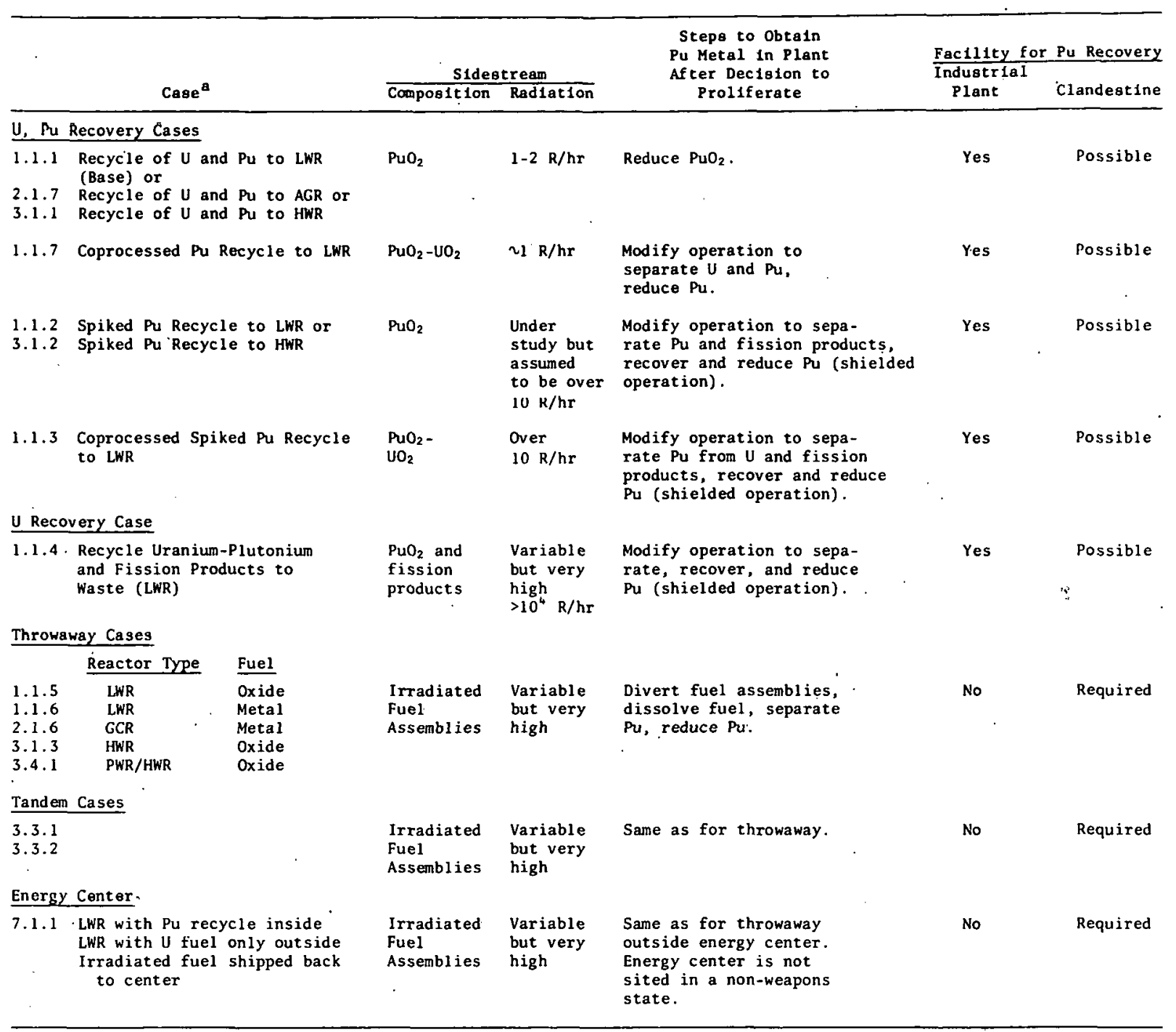

${ }^{a}$ Cases listed in order of increasing technical difficulty. 
Several techniques of spiking plutonium are listed in Table 5.20. All methods provide some deterrence to diversion of small amounts of fissile material, but none seem significantly proliferation-resistant. A11 would complicate the handling of the fuel and increase the risk of a severe occupational dose to members of the nuclear work force. Most methods impair the fuel fabrication process. However, all can be relatively easily defeated when a national determination is made to obtain purified plutonium. The ease of chemical separation of plutonium, fission products, and uranium (ion exchange, precipitation, or solvent extraction with valence adjustments) is not significantly complicated by the need for shielding to reduce dose rates. A national plan to assemble equipment for the task would not be delayed by radiation; cruder equipment and poorer yields with radiation would not seriously deter the task. For this reason, irradiated fuel assemblies (throwaway cases) or the mixture of plutonium and fission products (Case 1.1.4) would also provide appropriate feed materials for a covert crude plutonium recovery plan.

Fission products considered for spiking plutonium are characterized in Table 5.21. No isotope has ideal qualifications of high dose, long half-life, non-volatility, and chemical affinity for the plutonium stream.

Zirconium and ruthenium isotopes were suggested ${ }^{2}$ as the best candidates for deterring diversion (safeguards) in plutonium for up to 200 days after separation from fuel that had decayed 160 days. The fuel cost was estimated to increase 10 to $50 \%$ as a consequence of the fuel containing fission products. No consideration of resistance to proliferation was included in Reference 2 .

\subsection{REFERENCES}

1. A. J. Frankel and N. L. Shapiro, Appraisal of PWR-HWR Tandem Fuel Ciycles, Combustion Engineering Corp., Keport NYSD-45, 1977.

2. Bruce Hutchins, Denatured Plutonium: A Study of Deterrent Action, USERDA Report EPRI 310, 1975. 
Table 5.20. Splking Plutonium

\begin{tabular}{|c|c|c|c|c|}
\hline & Method & $\begin{array}{l}\text { Effect on } \\
\text { Fuel Process }\end{array}$ & $\begin{array}{l}\text { Means to } \\
\text { Defeat }\end{array}$ & $\begin{array}{l}\text { Radiation } \\
\quad \text { Level }\end{array}$ \\
\hline \multirow[t]{4}{*}{ A. } & Fission Products & & & \\
\hline & $\begin{array}{l}\text { Incomplete } \\
\text { Removal }\end{array}$ & Yes & Yes; recycle & $\begin{array}{l}\text { High; but will } \\
\text { decay }\end{array}$ \\
\hline & $\begin{array}{l}\text { Selective Partition } \\
\text { and Add-Back }\end{array}$ & Yes & $\begin{array}{l}\text { Yes; avoid } \\
\text { add-back }\end{array}$ & $\begin{array}{l}\text { High; but will } \\
\text { decay }\end{array}$ \\
\hline & $\begin{array}{l}\text { Irradiate Fuel after } \\
\text { Fabrication }\end{array}$ & No & $\begin{array}{l}\text { Yes; bypass } \\
\text { irradiation }\end{array}$ & $\begin{array}{l}\text { Yes; but will } \\
\text { decay }\end{array}$ \\
\hline \multirow[t]{3}{*}{ B. } & Cobalt Sources & & & \\
\hline & Mixed with Pu Fuel & Yes & $\begin{array}{l}\text { Yes; separate } \\
\text { chemically }\end{array}$ & $\begin{array}{l}\text { High; less } \\
\text { decay }\end{array}$ \\
\hline & $\begin{array}{l}\text { Added to Fuel Assembly } \\
\text { or to Pu Fabrication } \\
\text { Plant }\end{array}$ & No & Yes & $\begin{array}{l}\text { High; less } \\
\text { decay }\end{array}$ \\
\hline C. & ${ }^{238} \mathrm{Pu}$ & No & No & $\begin{array}{l}\text { Minor } \\
(\sim \text { few } R / h r)\end{array}$ \\
\hline
\end{tabular}


Table 5.21. Candidates for Fission Product Spiking of Plutonium

\begin{tabular}{|c|c|c|c|c|c|c|c|}
\hline Isotope & $\begin{array}{l}\text { Radiatio } \\
\text { R/hr @ } 1 \\
\text { Gamma }\end{array}$ & $\begin{array}{l}\text { vel, } \\
\text { kg Pu } \\
\text { Beta }\end{array}$ & Half & Life, yr & $\begin{array}{l}\text { Cross } \\
\text { Section, } \\
\text { barns }\end{array}$ & $\begin{array}{c}\text { Volatiles } \\
\text { In MOX } \\
\text { Pellet Fab. }\end{array}$ & $\begin{array}{c}\text { Simple } \\
\text { Contaminate } \\
\mathrm{Pu}\end{array}$ \\
\hline$Y^{91}$ & 1 & 5 & & 0.2 & 1.4 & - & - \\
\hline $\mathrm{Zr}^{95}$ & $2 \times 10^{3}$ & 2 & & 0.2 & - & - & Yes \\
\hline $\mathrm{Ru}^{103}$ & 40 & $<0.1$ & & 0.1 & - & Yes & Yes \\
\hline$R u^{106}$ & $2 \times 10^{3}$ & 200 & & 1 & 0.15 & Yes & Yes \\
\hline $\mathrm{Sb}^{123}$ & $15 n$ & 5 & & 2.7 & - & - & - \\
\hline $\mathrm{Cs}^{177}$ & $2 \times 10^{3}$ & 7 & & 30 & 0.1 & $Y e_{3}$ &.. \\
\hline $\mathrm{Ce}^{141}$ & 1 & $<0.1$ & & 0.1 & 29 & - & $\mathrm{No}^{\mathrm{a}}$ \\
\hline $\mathrm{Ce}^{144}$ & $7 \times 10^{2}$ & 200 & & 0.8 & 1 & - & $\mathrm{No}^{\mathrm{a}}$ \\
\hline
\end{tabular}

${ }^{\mathrm{a}} \mathrm{Pu}$ contaminated with a mixture of rare earths is achievable, but selective contamination with cerium and not gadolinium or samarium is very difficult. 
ORNL/TM-6036

\section{INTERNAL DISTRTRIITONN}

1-2. Central Research Library

3. Document Reference Section

4-5. Laboratory Records Department.

6. Laboratory Records, ORNL RC

7. ORNL Patent Office

8. R. E. Brooksbank

9-10. W. L. Carter

11. A. G. Croff

1.2. A. J. Frankel

13. M. R. Hill

14. D. R. Johnson
15-16. P. R. Kasten

17. R. B. Lindauer

18-19. A. L. Lotts

20. L. E. McNeese

21. K. J. Notz.

22. A. R. O1sen

23. R. H. Rainey

24. I. Splewak

25. D. B. Trauger

26. B. L. Vondra

27. R. G. Wymer

EXTERNAL DISTRIBUTION

28-38. ARGONNE NATIONAL LABORATORY, 9700 South Cass Avenue, Argonne, IL 60439

C. E. Ti11

D. S. Webster (10)

39-48. HANFORD ENGINEERING DEVELOPMENT LABORATORY, Westinghouse Hanford Company, P.O. Box 1970, Richland, WA 99352

H.C.F. Ripfel

49-58: E. I. du PONT de NEMOURS AND COMPANY, Savannah River Laboratory, Alken, SC 29801

F. R. Field

59. OAK RIDGE ASSOCIATED UNIVERSITIES, Institute for Energy Analys1s, Oak Ridge, IN 37830

M. J. Okanian

60-61. ERDA DIVISION OF REACTOR NUCLEAR RESEARCH AND APPLICATIONS, Washington, DC 20545

Director

Assistant Director for Nuclear Energy Assessments

62. ERDA DIVISION OF REACTOR DEVELOPMENT AND DEMONSTRATION, Washington, DC 20545

Director 
EXTERNAL DISTRIBUTION (ContInued)

63. ERDA SAN FRANCISCO OPERATIONS OFFICE, P.0. Box 81325, San Diego, CA 92138

Sentor Program Coordinator

64-87. ERDA DIVISION OF WASTE MANAGEMENT, PRODUCTION AND REPROCESSING, Washington, DC 20545

Assistant Director for Fuel Cycle

Chief; Technology Branch

Chief, Projects Branch

Ch1ef, Industr1al Programs Branch

F. E. Tooper, Projects Branch (20)

88-89. ERDA OAK RIDGE OPERATIONS OFFICE, P.O. BOX E, Oak RIdge, TN 37830

Director, Reactor Division

H. W. Behrman, Reactor Division

90-116. ERDA TECHNICAL INFORMATION CENTER, P.0. Box 62, Oak Ridge, TN 37830 